\title{
THE FIGHT WITH FRANGE FOR NORTH AMERICA
}




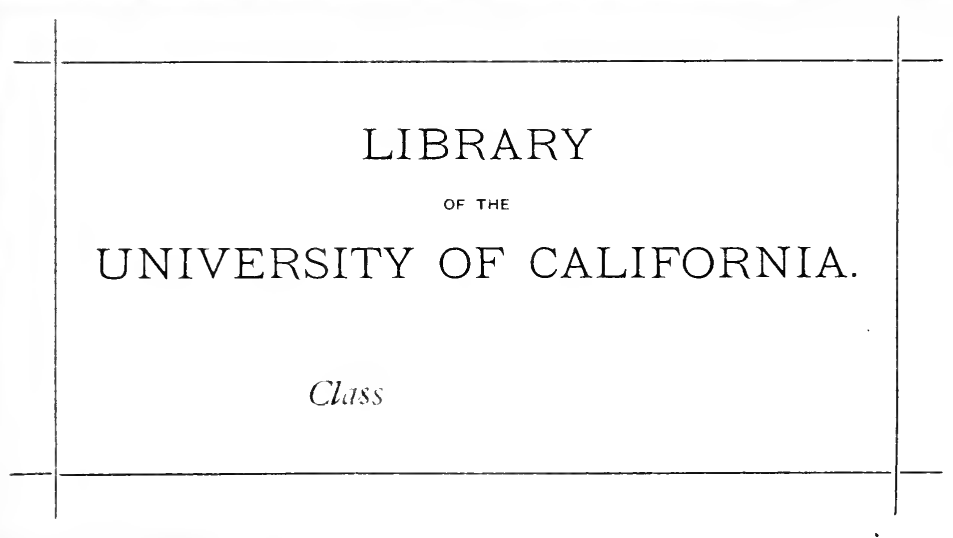





\section{THE FIGHT}

\section{WITH FRANCE FOR}

\section{NORTH AMERICA}





\section{THE FIGHT}

\section{WITH FRANCE FOR}

NORTH AMERICA

\section{BY A. G. BRADLEY}

AUTHOR OF "WOLFE" " SKETCHES FROM OLD VIRGINIA" ETC

NEW YORK

E. P. DUTTON AND COMPANY

WESTMINSTER

ARCHIBALD CONS'TABLE AND CO LTD 
boc 

E199
B8 


\section{PREFACE}

THE subject of this volume will, for the most

1 part, I have reason to think, possess at least the merit of novelty for the general reader. The oblivion to which in this country the American War of Independence has been consigned is at least comprehensible. It had few dramatic features, and for us was not glorious, either in motive or conduct. But the earlier war with the French power in America was not only rich in picturesque detail and dramatic situation, but formed an important part of the most glorious and most epoch-making struggle in which Great Britain was ever engaged. Yet no English writer, using the term in its narrow sense, has seriously touched the subject since Warburton, early in the century, published his two admirable volumes on the Conquest of Canada. The well-known Canadian historian, the late Mr. Kingsford, has devoted a great part of volumes III. and IV. in his exhaustive history of the Dominion to the period in question. But it is idle to speak of what may be called in general terms books of reference (however interesting to the student), when the fascinating pages of the brilliant American, Francis Parkman, are only known to so comparatively small a circle of English readers. On this very account it might seem vain to make any further attempt to recall the American campaigns of Braddock, Loudon, Abercromby, 


\section{PREFACE}

Amherst, Wolfe and others. Nor can I plead that the South African War, with its many points of comparison, influenced my decision, for this book was already in progress when this second struggle, if I may call it so, for racial supremacy on a distant continent was thrust on the British nation. The fortuitous selection, however, of this moment to retell the story of the Anglo-French struggle for empire in the old days of America may surely be accounted as all in favour of the undertaking.

As a matter of fact, the chief motive that impelled me to the attempt was nothing more than a strong attachment of very old standing to this and kindred subjects-an attachment begotten by many years of residence under the shadow of the Alleghanies, in the most vigorous and impressionable period of life, and stimulated by occasional wanderings with tent and canoe amid the wild and romantic waterways of Canada. I do not know that association with scenes where history has been made in any way strengthens one's qualifications for writing it, but I do know that in a case like this it greatly sweetens the labour.

One practical idea, at any rate, if not based perhaps on a very elevated hypothesis, I had before me in the writing of this book-namely, that a single volume on an unfamiliar subject may perchance in these socalled busy days find readers where a bulkier work of greater merit might be left upon the shelf.

I make no attempt in these pages to address the serious student of this war, if indeed there be any such on this side the Atlantic. I have few incidents to relate that have not been told with greater elaboration elsewhere; indeed, I am writing more 


\section{PREFACE}

especially for those to whom nearly the whole story will be new, and have even thus no small difficulty in condensing its more salient and familiar features within the necessary limits.

The founding of our Indian Empire is more or less related in the biographies of Clive and Hastings, as well as in other short and handy books, and is by those popular channels made comparatively familiar. Wolfe's life, on the other hand, but partially touches on the struggle which destroyed the French power in America, though he is the hero of it. For Wolfe flashed like a meteor on a contest already many years old, and vanished in a blaze of glory that, though decisive in a sense, was not by any means the closing scene. Every schoolboy knows, or is popularly, though probably very erroneously, supposed to know, the details of the Plains of Abraham, but I will undertake to say that there are many thousands of schoolmasters who have never so much as even heard of the still bloodier battle of St. Foy, fought upon the same ground, within six months, by the same troops ; while, so far as my experience goes, the memories of Braddock's defeat, Ticonderoga or Louisbourg are much more often than not of the haziest description, and sometimes are barely even memories in quarters where such recognition would be most expected.

The great Anglo-Saxon family quarrel which robbed Great Britain of the very colonies for whose relief she had spent so much blood and treasure is a question to itself, and a sufficiently big one. But it in no way affects the decisive nature of the French defeat and the far-reaching consequences which contributed to make the signing of the Treaty of Paris in $\mathbf{1 7 6 3}$ 


\section{PREFACE}

the most glorious and the most pregnant moment in recent British history; though Pitt, to be sure, did think it might have been still more emphatically marked. In its significance for the Anglo-Saxon race at large no epoch will compare with it.

The title of this book requires, perhaps, a word of explanation. For one thing, I shall doubtless be informed that Mexico is geographically in North America, and has not yet been annexed to AngloSaxon dominion, and may never be. To say that one regards Mexico as belonging rather to the atmosphere of South America would be a poor excuse. It will be more honest to at once admit that I sought long and vainly for a title that would convey, with sufficient brevity, the nature of the work and explain its purport on a book list, before adopting one that involved a technical inaccuracy.

Alternatives will no doubt present themselves at once to most minds, as they did to mine, but it will be sufficient here, I think, to say that none of them seemed to me lucid enough when it is considered how hazy is everything transatlantic to the English mind. "The Seven Years' War in North America" would be the natural and logical title for such a book as this. I have a notion that a reviewer would say that it was sufficient and unmistakeable. But a literary critic would not be human if his own range of books and subjects did not lead him to sometimes underestimate the oblivion under which some chapters of history rest in the popular mind. For myself $I$ feel quite sure that such a title as the above would suggest in many quarters some struggle in which neither England nor France nor the world at large had any great concern. 


\section{PREFACE}

The printed, as well as the MS. material, in the shape of history, biography, journals, and papers bearing on this war is very ample. In the many volumes of State papers at the Record Office relating to these events, I can find nothing worthy of notice here that has not been utilized in English, American, or Colonial works. Among modern historians Parkman, Kingsford and Warburton stand alone in the attention they have given to this period in America. Among older and more or less contemporary writers, Smollett, Mante and Entick are prominent; while of the numerous diarists Knox is the most exhaustive and valuable upon the English side.

It is not, indeed, from lack of sources of information that so undue a mist would seem to cover this fateful chapter of British history. I only hope that my effort to present it in handy form may help to remind some few at any rate of that incomparable moment when the star of England shone with a lustre greater even than during the epoch that witnessed Waterloo and saw Napoleon carried in a British ship to St. Helena.

A. G. B. 



\section{CONTENTS}

\section{CHAPTER I}

PAGE

The Treaty of Aix-la-Chapelle-Condition and Characteristics of the British-American Colonies and of Canada in 1750

\section{CHAPTER II. 1747-1754}

French Designs against British Expansion-French Expedition to the Ohio Valley-The Acadians-Washington carries the English Protest to the Ohio-Fight at the "Great Meadows "-Beginning of the Struggle .

\section{CHAPTER III. 1754-1755}

A British Force despatched to America-Braddock's Expedition to the Ohio-His Defeat on the Monongahela-His

Death-Disastrous Results

CHAPTER IV. 1755-1756

Shirley occupies Oswego-Johnson's Futile Campaign on

Lake George-Deportation of the Acadians-Apathy of

Pennsylvania-The British Frontiers wasted . . .

CHAPTER V. $1755-1756$

Formal Declaration of War between France and England-

Montcalm sent to Canada-Lord Loudon takes Command of the British Forces-His Useless Campaign on Lake George-Montcalm captures Oswego . . . . .

\section{CHAPTER VI. 1756-1757}

Difficulties in Forming a Ministry-Pitt succeeds to PowerFrench Attack repulsed on Lake George-Another British Force sails-Loudon's Futile Expedition against Louisbourg-The French capture Fort William Henry-The Massacre

$$
x i
$$




\section{CONTENTS}

\section{CHAPTER VII. $1757-1758$}

Low Ebb of British Fortunes-Military Apathy in Middle and Southern Colonies-Official Corruption in CanadaMagnetic Influence of Pitt on British Affairs-Wolfe and Amherst-Siege and Capture of Louisbourg-Rejoicings in England . . . . . . . . .

CHAPTER VIII. 1758

Abercromby takes Command in America-Large British Army gathers at Albany-Abercromby attacks Ticonderoga-Repulsed with Great Loss-Campbell of Inverawe

\section{CHAPTER IX. 1758}

Bradstreet captures Frontenac-Forbes leads an Expedition against Fort Duquesne-Defeat of Grant and Highlanders near the Fort-Post, the Moravian MissionaryForbes occupies Fort Duquesne-His Death . . .

\section{CHAPTER X. 1758-1759}

The Expedition against Quebec under Wolfe-Difficulties of the Siege-Battle on the Plains of Abraham-Death of Wolfe and Montcalm-Surrender of the City. . .

CHAPTER XI. 1759

Flight of the French Army from Quebec-Murray in Command of the British Garrison-Amherst captures Ticonderoga and Crown Point-Prideaux takes Niagara . .

\section{CHAPTER XII. 1759-1760}

British Army winters in Quebec-French, undèr Lévis, return and attack the City-Battle of St. Foy-Quebec relieved by British Ships-French Forces retire on Montreal-Murray ascends the St. Lawrence to Montreal-Amherst descends the River from Lake OntarioHaviland, with Third Army, joins them from the SouthSurrender of Montreal and the French possessions in North America to Great Britain

Conclusion 


\section{LIST OF MAPS}

TO FACE PAGE

Canada and the British Colonies in 1750 . (Frontispiece)

Map showing the Two Military Highways between Canada and the British Colonies . . . . . . . 109

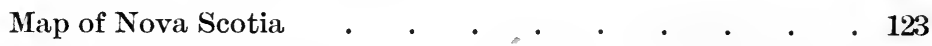

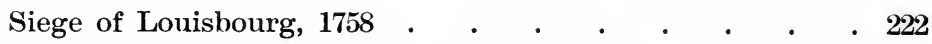
The Attack on Ticonderoga, July 8th, 1758 . . . . 239

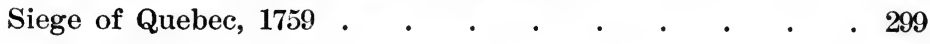





\section{ERRATA}

Page 19, first two lines should be transposed.

Page 54, for "Hobson" read "Hopson."

Page 78, line 25, for " Catholic king" read "Christian king."

Page 151, headline of page, for "Soldier" read "Soldiers."

Page 155, for "Pepperall" read " Pepperell."

Page 163, headline of page, for "The Fight with France" read "Without a Leader."

Page 311, for " of Pitts. Though" read " of Pitts, though."

Page 317, note, for "fatuitously" read "fortuitously"; for "the family. A beautiful specimen" read "the family; a beautiful specimen."

Page 318, note, for " Professor Robson " read "That of Professor Robison."

Note appertaining to page 327.

In a letter written on the field of battle at two o'clock by an officer to his friends in England, which lies before me, the duration of the fight is estimated at half an hour. The writer is Colonel de Ruvigny, R.E., grandson of the Count de la Caillemotte, killed at the Boyne, and great grandson of the celebrated Huguenot statesman, the Marquis de Ruvigny, and himself subsequently fifth Marquis de Ruvigny (de jure), and a naturalized English subject. I am indebted to the courtesy of the present representative of the family for the letter in question. The fact that it is written in French is a curiously significant comment on the policy of France towards its Protestants. The writer speaks of the fury of the French attack, and the confusion of their retreat. He deplores the death of Wolfe, and speaks of the reported or expected death of Montcalm as removing the one leader in whom the Canadians were supposed to have confidence. 



\section{CHAPTER I}

THE war of the Austrian succession, ever memor1 able to Englishmen for the fierce fights of Dettingen and Fontenoy, was brought to a close in August, 1748, by the peace of Aix-la-Chapelle. For her lavish expenditure of blood and money, Great Britain had reaped little other profit than a qualified measure of renown. She had shown to the world, however, that nearly thirty years of peace had not robbed her soldiers of their ancient valour, even when handled, as they too often were, with conspicuous incapacity and officered by a system that took no cognizance of merit and was based almost wholly on favouritism and corruption.

At Fontenoy the twelfth regiment, to take a chance instance, was led into action by a captain. At Dettingen the major was in command, while James Wolfe, then a callow youth of sixteen, had to grapple as best he could with the onerous and responsible duties of adjutant, complaining bitterly in his letters of the lack of discipline. Marlborough's officers were dead or doting. Privilege and faction regulated the pay list, though it is well to remember that the beardless colonel died as freely and fought as courageously as the grey-haired subaltern. Let it ever be , borne in mind, too, that the king himself and his burly son, the Duke of Cumberland, were 


\section{THE SEVEN YEARS' WAR}

bright examples of this cardinal virtue of physical courage, and asked no man to dare what they would not dare themselves-nay, were only eager to. They, at least, were not responsible for the unwholesome thing that squandered human life and courted disgrace. If the Duke's level of capacity, moderate though it was, had been maintained throughout the service, there would not have been a great deal to complain of ; while to a modern monarch, who asks for nothing better than the heat of battle, and when in it bears himself right nobly, much may surely be forgiven, or ought to be. If George II. had been spoiling for war, and had personally contributed for no sufficient reason to the closing of Walpole's long and prosperous peace in 1739, the people at large, without his excuse-for Hanover was nothing to them-were equally bellicose. If the peace of 1748 left the country with little to show for its big bill, the renewal of the conflict eight years later proved in this matter of a profit and loss account a most singular and brilliant contrast. The mighty struggle commonly known as the Seven Years' War should be kept separate in Englishmen's minds from all other contests in which the nation has been engaged, for it lifted Great Britain from a constantly fluctuating position of more or less equality with rival powers to the first place among the nations of the world. ${ }^{1}$ It made her the permanent mistress of the seas and of a world empire unshaken by the military and social upheavals of Europe, whose territorial disputes and dynastic struggles seem by comparison almost trifling

1 The revolt of the American colonies may almost be called a domestic rupture. At any rate, it did not, as was expected, lower the position of Great Britain. 


\section{SUPREMACY IN NORTH AMERICA}

but for the torrents of blood they caused to flow. Above all, it inspired her people with a sense of conscious power, of worthy pride sobered by the vast responsibilities that accompanied so great a position, and a self-confidence that was never again seriously shaken.

But as here we have to do only with the Western continent, and not with the contemporaneous founding of the Indian Empire, it will be enough to recall the main issue that was at stake in North America. Whether Canada-or, to speak more pertinently, what is now British North Americawas to be French or English seems a sufficiently large question when weighed in the balance with the possession of Minorca or the boundary of a German duchy. But even this shrinks in importance when compared with the still greater issue of AngloSaxon or Gallic supremacy on the continent of North America.

Recent events at the sources of the Nile should stimulate our interest in a crisis of infinitely greater moment that a century and a half ago was solved by the gauge of battle. We know something nowadays of that kind of colonization, which consists in hauling up flags and map-making and tactics that are merely obstructive of a rival's industrial enterprise without the power of wholesome competition. It may be human and natural and entirely venial, but on that very account is only entitled to consideration on the same low plane-that of physical force. It is a far cry from Fashoda to the Ohio, from 1899 to 1754. But the most enthusiastic dreamer of African dreams will hardly contend that the Nile hinterland, even with Egypt thrown in, was com- 


\section{TREATY OF AIX-LA-CHAPELLE}

parable as a stake to the North American continent-a white man's country and a white man's climate. $^{1}$ This, however, was the stake for which France played in the days of Louis XV., and, thus venturing, lost not only her former position, but her very existence as a transatlantic power.

Though nearly all Europe was in arms, it is with France and England that we are here alone concerned. Great as were the exertions put forth against other powers by these two nations, it was only each other that they had real cause to dread. Their respective armies might win or lose in the Low Countries or Germany, a million of human beings might perish, and torrents of blood might flow, and volumes of military history might be made; but so far as the Western actors in it were concerned, it began and ended with the game of war, waged upon wholly frivolous or personal accounts. Except for the still far-off results of the military development of Prussia under Frederic, the destinies of the world were but little affected by the long misery and suffering under which Europe groaned. To France and England, at any rate, the issue was as nothing compared to that for which their scattered outposts were contending in the pathless forests of America, on the burning plains of India, among the fogs and ice-fields of the North.

The peace, or so-called peace-more accurately described by some historians as an armed truce-which lasted from 1748 to 1756 witnessed the first stealthy

1 Since this chapter was written, the South African war has given us the picture of another great racial struggle; the minor details of which are, at times, singularly suggestive of the Seven Years' War. 


\section{THE AMERICAN POLICY OF FRANCE}

efforts of the French American policy, the awakening of England to her danger, and the actual opening of the struggle.

As a matter of fact, the treaty of Aix-la-Chapelle had not been signed, nor indeed actually formulated, when the French rulers of Canada, with the sympathy of their king and Government, commenced the operations from which they hoped so much. Their purpose, stated briefly, was to confine the future influence and territory of England to the thirteen colonies which lay at present a mere strip along the Atlantic coast. Behind the more northern of these the scope of Western development was limited, for obvious geographical and other reasons. The treaty Indians of the Six Nations occupied the rear of New England and New York; while behind these, again, stretched the great water-way of the St. Lawrence and its lakes, which constituted the Canadian boundary. But at the back of all the other colonies, trending southwards and nearly parallel with the coast-line, the great range of the Alleghanies lifted its shaggy peaks. The limits of civilization had barely touched it. Nowhere had British settlement as yet aspired to leap this broad barrier of forest-covered mountains into the dreaded Indian-haunted wilderness beyond. The policy of France was to prevent it, if possible, ever doing so, and to make the rampart which nature and Indian hostility had already made so formidable still more effective by erecting a chain of military posts behind it. The French were well established on the St. Lawrence and its parent lakes. They had considerable settlements at the mouth of the Mississippi. Their cherished scheme was to connect the two by a long line of 


\section{STRENGTH OF THE RIVAL RACES}

forest fortresses, to form firm alliances with the warlike Indians behind the Alleghanies, and to hold for themselves the vast Western territories, of whose value and extent their daring explorers had given them a due appreciation.

The English colonists may fairly be described as unconscious of these schemes or of their import. They had more than sufficient territory for their needs upon the east of the Alleghanies. The mass of them were stay-at-home farmers and planters. Neither Imperial dreams nor future divination were in keeping with their habit of thought. Frenchmen were but vague figures in the imagination of all men south of the Hudson, and the great West but a hazy expression. The British Government, too, troubled its head very little about its colonies; and if in the latter there was a small handful of men who did divine a future so pregnant with vital issues, and raised the alarm, posterity has given them little more of honour than their contemporaries gave them of reward.

Before proceeding, however, to the story of the great struggle, it is indispensable that the reader should have some idea of the relative positions of the two parties to it in North America.

Now the French in Canâda, exclusive of some 10,000 Acadians, who were nominally British subjects, numbered about 60,000 souls. The English colonists, on the other hand-or, to be more accurate, the colonial subjects of Great Britain in North Americawere reckoned by the middle of the eighteenth century at nearly a million and a half. A fifth or a sixth of this number, to be sure, were negro slaves-a source of weakness rather than of strength. But, in any 


\section{THE THIRTEEN COLONIES}

case, the preponderance of the British was so overwhelming that the notion of the French being a menace to their present security or a rival for future dominion seems at the first blush incredible. The test of numbers, however, was never a more fallacious one than in this particular case, nor is the apparent paradox at all simplified by the fact of the Englishman's robust personal qualities, both as a man, a soldier, and a colonist.

A short glance at the situation and distribution of the rival races will, I think, show that though the French aspirations were sufficiently audacious, they were very far from being hopeless. The French were concentrated at one point; the British were scattered over an immense area. The former bowed unquestioningly to an autocratic rule; the latter were divided into thirteen distinct self-governing commonwealths. While the Canadians were the obedient tools of king and Church, were generally poor, alert, and warlike, the English colonists were jealous of all authority, absorbed in trade and agriculture, and eminently peaceful. We have now grown so accustomed to think of the Anglo-Saxoninhabitants of our former colonies as Americans and more or less a homogeneous nation, that it requires a mental effort, together with some little grasp of the old state of affairs, to fully prepare oneself for an appreciation of the struggle of 1755-60.

The reader will not resent, I trust, being reminded of the fact that the thirteen colonies whose growing power the French so dreaded, and thus dreading tried to stifle, are represented, with some slight modifications, by the thirteen original States of the Union. They may be seen in the map of to-day 


\section{INTER-COLONIAL JEALOUSY}

much as they were in the old French wars, trailing down the Atlantic coast from the Canadian border to the then Spanish province of Florida.

Not one of these thirteen commonwealths had any sort of constitutional link with its neighbour. The only tie that bound them together was their common allegiance to the Crown. They were for the most part jealous of each other, and more often inclined to thwart than to promote mutual interests. Some had affinities of race and creed, and in matters nonadministrative more readily coalesced; while others, again, cherished towards one another a positive aversion. Each colony had, at some period during the preceding century, begun life upon its own account, and had grown up quite independently of its neighbour and after its own fashion. Some of them, indeed, in the elementary stages of existence had gone so far as to indulge in mimic conflicts, and over the matter of boundaries there was perennial friction. This long straggling line of jealous and often jarring commonwealths resting on the seacoast was the base of British action against the compact, military colony of France; and a most unsatisfactory base it for a long time proved.

The four New England provinces with that of New York had the friendly but uncertain Six Nations and the French, with their bloodthirsty, so-called Christian Indians, more or less perpetually upon their flank. The rest, from Pennsylvania to infant Georgia, with rare exceptions, had forgotten the earlier horrors of Indian warfare, and had scarcely so much as even. set eyes upon a Frenchman. Their pioneers had straggled through the forests that covered, as with a mantle, all Eastern America to the foot-hills 


\section{THE WEST NOT YET CONSIDERED}

of the Alleghanies; but colonial life in its active and vital sense still clustered along the sea-coast, or hugged the waterways that led there. Between the Alleghanies and the ocean most of the colonies had a territory, roughly approximating to the size of England, with a population of but one or two hundred thousand souls in each. Their people wanted plenty of elbow-room, particularly to the southward, where negro labour was largely used; but even in such case the time had hardly come when lust of land prompted perilous enterprises. Society was not yet dense enough to produce a surplus who considered it worth while to cross the mountains and renew the fight with a fiercer wilderness and a more formidable, for better armed, savage than their grandfathers and great-grandfathers had waged war against in the days of the Stuarts and William of Orange. Men who had a sufficient livelihood, too, were less feverish and more contented in those times than in later ones. Nor were they much better equipped for subduing the savage and the wilderness in the days of the Georges than they had been in those of the Tudors and Stuarts. Those all-powerful factors of civilization - steam and electricity - were un- dreamt of. Machinery and scientific road-making were in their infancy. It is not surprising that Virginia, for instance, with a white population of 200,000 , and a territory between the mountains and the sea as large as England, and as generally habitable, should have troubled itself little with thoughts of distant adventure. There was no incentive whatever for the Virginian, or Carolinian, or Marylander of 1750 to cross the Ohio watershed and fight the most formidable savage warrior that the world has 


\section{THE NEW ENGLAND COLONIES}

ever seen, for the privilege of growing corn and hay, or stock, that he could not get to any market, even if he lived to make the attempt. The average colonist of those days, leading, south of the Hudson at any rate, a humdrum, comfortable life, cannot be blamed if he failed to grasp the situation, or read the map of America as we read it now, and was inclined to look upon the reputed schemes of wandering Frenchmen as hardly worthy the attention of practical men, till the rude awakening came.

A glance at the map will show that the New England colonies, at that time four in number, together with New York, had no outlet to the then scarcely known and little appreciated West. As I have said, they had behind them the famous "Six Nations," a leading factor in the American politics of that day, by far the most powerful Indian combination, and at the same time the most in touch with colonial civilization. Unlike the other Indian tribes, their sympathies had been consistently pro-English. But even so, they may be said to have held, in some sort, the balance of power between the English and the French, which latter nation were perpetually intriguing for their alliance.

Massachusetts, Connecticut, Rhode Island, and New Hampshire, standing in the order named as regards relative importance, constituted the Puritan colonies of that day, Vermont and Maine being carved out of them later. These provinces alone understood, though perhaps not very perfectly, the art of combination for offensive and defensive war. They were practically homogeneous in stock and creed and habits of thought. Both the Indian and the Frenchman were still for them a burning reality, and they knew 


\section{THE NEW ENGLAND COLONIES}

them only too well. They were much the most warlike group of the British colonies, not from choice, but from necessity. Their origin and Puritan tone of life are so familiar as to be hardly worth an allusion; but the vulgar error of supposing the New Englanders to be all of humble extraction, while the Southern colonists had a monopoly of blood, cannot be sufficiently held up to ridicule. Numbers of cadets of arms-bearing and land-owning families went to New England, but both political and social life was there cast in democratic lines, and local conditions did not favour the acquisition of great estates. An influential and higher class of varied origin arose in New England as in the South, but they had to maintain their position by superior force of character and intellect, perhaps, rather than by superior estate. At the same time, as near an approach to social equality as is possible among an educated and civilized community existed in New England. Local government was highly organized, and politics a matter of universal interest. People lived in communities, very much under the eye of their neighbours, and of a public opinion to which no slight deference was paid.

This latter was narrow, vigorous, and at times tyrannical, and strongly influenced by a religious bigotry that bordered on fanaticism. Tempered by modern progress and a high education, the New England character has broadened into a type whose good points are greatly in the ascendant. In the colonial period the asperities of the average New Englander were uppermost, his virtues less evident to his fellow-colonists, by whom he was cordially disliked; while the same antipathetic feeling dis- 


\section{NEW ENGLANDERS AS SOLDIERS}

tinguishes the sentiments of all English travellers of that day. ${ }^{1}$ In education, however, at that time the New Englanders as a community were far in advance of the rest of the continent, and, for that matter, of the rest of the world. Indigence and ignorance were almost unknown; and though there were no rich people, there were scarcely any who were very poor. The same religious and political zeal which had created their schools, churches, and local governments made some sort of military organization easier for them than for their more apathetic neighbours.

At the same time, while better constituted for raising, feeding, and paying regiments, their social system contained in itself drawbacks to military efficiency not so obvious in the other colonies. Every private, whether farmer, fisherman, or mechanic, was a politician, and, though ready to fight, watched with jealous eye lest his terms of service, often loaded with conditions, were in danger of being infringed. Still worse, perhaps, the officers were chosen by the men they were to command - not a bad plan in a company of experienced bush-fighters bound on perilous enterprise, but one fatal to discipline when extended to a whole army of raw militiamen. Massachusetts was far the most powerful of the New England colonies, while Connecticut was easily second. These provinces, moreover, had produced both writers and preachers whose fame had crossed the Atlantic. They had performed, too, more than one spontaneous feat of arms which did them credit and gained them the thanks of the mother

1 The higher class of Bostonians are usually exempted from the strictures of these travellers. 


\section{THE COLONY OF NEW YORK}

country. In the very last war, in the year 1745, and at a moment of depression to British arms in Europe, their raw militia, with the help of the fleet, had attacked and captured the great French fortress of Louisbourg. In the coming war they were to far eclipse the efforts of all the other colonies combined, and twenty years later, in that of the Revolution, were to hold an only less decisive lead. Yet in $\mathbf{1 8 6 0}$ the seceding States of the South had so far forgotten American history as to profess a conviction that "The Yankees would not fight." The awakening was bitter, as we all know.

New York to some extent had shared with the Puritan colonies the perils of French and Indian neighbourhood, and like them had been compelled, only in a less degree, to organize and to fight. She was widely different, however, both in origin and composition. The Hudson River was her great artery, and along its banks for the most part the life of the colony throbbed. The city at its mouth was then, as now, the most light-hearted and cosmopolitan upon the Atlantic coast. Its population was somewhat heterogeneous, but the English and the Dutch largely preponderated, and alone influenced the life and tone of the colony. On the seaboard nearly all trace of the early jealousy that had not unnaturally distinguished the two races had disappeared with the tie of a common danger, a common Protestantism and a free government. The cast of society was aristocratic and in curious contrast to the Anglo-Dutch peoples of South Africa. The Hollanders were indeed partly responsible for the tone. Great estates upon the Hudson had been originally granted to Dutch gentlemen on condition of their settling 


\section{PENNSYLVANIA}

them with dependants in semi-feudal fashion. The Patroon families were few in number, but perhaps the nearest approach to a feudal aristocracy in North America. English families who had achieved wealth and distinction or had official positions intermarried with these, while there was a tendency in the older parts of the colony for broad acres and gentility to identify themselves together and to hold aloof from the mass of the people. In spite of the strong Dutch element, the prevailing creed was Anglican. The succession of William of Orange to the English throne, and still more perhaps a zealous Protestantism and a lively dread of both the Indians and Catholic French, had produced a loyalty that, with some notable exceptions, was in a fashion more ardent than that of the republican Puritans of New England. Nor did the admirable Huguenot element, which found here a hearty welcome and freedom from persecution, in any way dissent from the attachment to a Government that made their lives once again worth living. No stratum of provincial life was greatly agitated by religious or political dogmas. It was an easy-going, prosperous, but perhaps slightly colourless community, which at its capital went to balls and plays and made merry according to its degree without any fear of the village deacon or the Quaker legislator. ${ }^{1}$ New Jersey, or the Jerseys-for it was once divided-and Delaware, were colonies of secondary importance, and somewhat polyglot in population; communities of farmers of various nationalities,

1 This description would not apply to the Dutch of Albany and the Upper Hudson, concerning whom see a later note. 


\section{THE SOUTHERN COLONIES}

lacking in any characteristics that one can take hold of without undue elaboration.

Pennsylvania, on the other hand, from her size, prosperity, and large population, was of great importance. As a military factor, however, she was almost a cipher - a condition due, of course, to the powerful Quaker element in her population. What was not Quaker was very largely German, stupid for the most part, speaking only its own language, and always indifferent to everything but its own personal concerns. To the back country on the Alleghanies the stream of a more virile population, to be sure, had been long finding its way from the north-east of Ireland, about whom a word will be said later. But Pennsylvania, as a whole, was fat, prosperous, and fanatically pacific. Her seaboard counties were fertile and well farmed, while if Boston was the most serious, and New York the most worldly, Philadelphia was the most comfortable of colonial capitals. Fight Indians or Frenchmen, however, more particularly as they were tolerably safe themselves, its people would not: a sore point enough with their neighbours, as we shall see later on. ${ }^{1}$

Maryland and Virginia may, for purposes of general description, be fairly classed together. Negro slavery was a feature in all the colonies, but it was not till the traveller reached Maryland that he found it a leading factor in social and economic life. Then,

1 Pennsylvania had been originally settled by Swedes in 1627 . They were forcibly subjugated in 1655 by the neighbouring Dutch of New Amsterdam (New York), who themselves passed under English rule in 1664. Philadelphia and Pennsylvania proper were founded by Penn in 1682. 


\section{VIRGINIA}

as a century later, though in a less marked degree, the slave line, which was identical with the northern boundary of the old Catholic province, divided AngloSaxon America in half. The Southern colonies were already diverging upon lines so similar to one another, and so at variance with the rest, as to give them in time quite a reasonable pretext for posing as a separate nation. In 1750, however, things had not gone nearly so far. Yet Virginia was even then so pronounced a type of the Southern provinces that a brief description of her condition will enable us to dismiss the others with a word.

As Massachusetts was the oldest and most powerful of all the Northern colonies, so was Virginia the oldest and most influential of the Southern group. Her people were almost wholly of English stock, and at this time numbered nearly 200,000 , with more than half as many negro slaves. They were a community of agriculturists, divided into three practically distinct social grades. There were no towns worth mentioning, and no trade to speak of. The production of tobacco, and the foodstuffs necessary to those who grew it, was the sole industry; the ownership of land and negroes the test by which men were graded. Upon the basis of this an aristocracy arose, which was to some extent crystallized by laws of primogeniture and entail. All the world knows Virginia was the cavalier colony, and knowing this much has been greatly addicted to exaggerating its significance. Virginia was first settled neither by political nor religious refugees, nor yet by idealists of any kind. Its early colonists were Englishmen by blood, in no way discontented with English institutions, but on the contrary anxious to reproduce as 


\section{THE EVOLUTION OF VIRGINIA}

nearly as might be another England beyond the Atlantic.

The contour of the country, the early shipment of convicts and others as indented servants, together with the episcopal and English spirit, encouraged after the first rude beginnings the unit of land as the fountain of power and influence. Some of the colonists were cadets of good families, though what proportion (a small one probably) they ultimately formed of those who emerged as large landholders and the founders of notable families is most uncertain and of little importance. At any rate, the period, though not remote enough perhaps to win respect from the Latin or the Celt, is sufficiently so to satisfy the modest genealogical requirements of the average Anglo-Saxon. The popular local legend that the Virginian gentry were largely descended from scions of the then small body of English nobility is too ludicrous to call for serious notice.

The nomenclature of the earlier settler in Virginia at once dissipates so absurd a theory. A moment's thought would remind any person of ordinary historical knowledge that the small group of privileged individuals who constituted the British nobility of the seventeenth century had opportunities at home and on the Continent of forwarding the interests of their offspring of a more congenial and brilliant kind than would be implied by banishment to the life of a settler in the backwoods of America. The numerous squirearchy of that day are of course quite another affair, and that they of their abundance contributed a quota of younger sons to what became the ruling class of Virginia is quite a reasonable notion, for the alternative as 


\section{THE INFLUX OF CAVALIERS}

often as not was apprenticeship to a tradesman or country attorney. ${ }^{1}$

However that may be, the early sentiment of the colony was to get as much land as you could, and as much unpaid labour. Conditions encouraged an imitation of English life so far as circumstances would admit. As soon as the rough and ready democracy, inevitable to the pioneer period of a community struggling for a livelihood in a timbered country peopled with hostile Indians, had opportunity to stratify, it seized it. When the grandchildren of the first settlers were still young, the nucleus of another England had arisen: parsons and parish churches, county lieutenants and magistrates, and the beginnings of a rural aristocracy.

The death of Charles I. sent another wave of immigration to the colony, that intensified its early predilections for conservative English ways. This was composed of loyalists from every class of the community whom the fortune of war had deprived of property or employment. Though many of them, including most of those who were of note or influence at home, returned at the Restoration, the stimulus given

${ }_{1}$ People possessed of the popular fallacy that in the "good old times" the sons of country squires held aloof from trade and only followed "the professions" would experience a rude shock on the slightest examination of family history in the 17th and earlier 18 th century, and for most obvious reasons. The squirearchy was relatively much more numerous than now. Individual families larger. There was no standing army worth mentioning. The navy was mostly officered by rough sea dogs. Macaulay's familiar picture of the country parson carousing in the servants' hall, and marrying my lady's waiting woman, is at least suggestive enough of the social dignity of the Church. The Bar was extremely expensive, and much more the resort of heirs to property than of younger sons. 


\section{SOCIAL VIRGINIA}

formulated in Virginia was very great, and fixed it to the Anglican and stratified form of life already in such fashion as neither republicanism nor still greater social earthquakes in modern times have been able wholly to destroy. "Everybody here," wrote a seventeenth-century governor of Virginia (alluding to the planters), "would fain be a gentleman."

By 1750 it had been tolerably well settled who were and who were not. There were the great planters, the plain farmers or yeomen, the labouring white men, indented servants of a varied but mostly low type, and lastly the negro slaves. The first three classes merged indefinably into one another, of course, but of the ascendency of the upper class in social and political life there was not the smallest doubt. They formed the Governor's Council or Upper House, and except in the newer back counties, where life was naturally more democratic, filled the House of Burgesses, which was a salaried assembly. They monopolized all the Crown appointments, and at the same time profited by a system of taxation that fell far more hardly on the poor than on the rich. They were, however, penurious to a fault in the expenditure of public money, always excepting the matter of their own salaries. They were at constant loggerheads with the royal governor, or the deputy who usually represented him, either upon the question of patronage or of his official salary; but this in no way interfered with the "Church and King" tone of the colony. They sent their sons to England for their education when they could afford it, but otherwise utilized the services of the very indifferent clergy as no doubt equally indifferent tutors. They 


\section{MODE OF LIFE IN VIRGINIA}

led patriarchal, isolated lives on plantations cut out of the forests, and for the most part abutting on tidal rivers, whence English ships carried home their sole produce-tobacco-and supplied them with such necessaries as they could not procure at home, and such luxuries as they could afford. They were a pleasant, hospitable people, who, unlike the typical New Englander, at once took the fancy of the stranger, their whole system of life being based on uneconomic principles. They were inclined themselves to be extravagant, and to forestall their incomes, and as their one crop, tobacco, restricted by navigation laws to an English market, fluctuated terribly in price, the colony was liable to equivalent fluctuations in fortune. Its upper class, however, with many of the faults due to a life of peculiar seclusion from the outer world, and the demoralizing influence of negro slavery, were generally frank, sensible, and able for any emergencies to which they might be called from their normal humdrum and comfortable life when once aroused. ${ }^{1}$

The middling class owned in concrete a vast quantity both of land and negroes. But, unlike the Northern yeomanry, they had no education, for there were no schools. The presence of slavery had even thus early implanted a certain contempt for manual labour, which is wholly mischievous in a grade of society that has neither birth nor education, nor yet possessions sufficient to justify abstention from it. The energy and utility of the common farmers of Virginia

1 Burnaby, Smythe, Weld, Captain Anbury, the Swedish scientist Dr. Kalm, and other European travellers, have left interesting pictures of social life in Virginia and the Southern colonies at or about this period. 


\section{NORTH AND SOUTH CAROLINA}

and the Southern colonies were then, and for a century afterwards, greatly sapped by this demoralizing influence. Upon the class below it had a far worse effect, the "poor white" of the South from that day to this being the most degraded type of Anglo-Saxon in existence, and beyond all doubt the greatest outcast.

I have dwelt thus long on Virginia for the reason already given; namely, that she may fairly stand, with modifications, as a type of her Southern neighbours. Maryland had all her features, though in some points less pronounced. In her inception she had presented the unwonted spectacle of a Roman Catholic province inculcating the notion of complete toleration. ${ }^{1}$ With time and increased population, however, she had drifted into a community chiefly Anglican in creed as well as in blood and sentiment. North Carolina was a rough and rude imitation of both. Her upper class was weak, and did not stand out like that of Virginia. Though a large slaveowning colony, North Carolina never achieved the social éclat of her slave-owning neighbours. Her population, though largely of British origin, was much less homogeneous than that of Virginia, which had only a small German element in its back country, and a slight dash of Huguenot blood in its older settlements.

1 In 1692 the Church of England was established by law, Dissenters and Catholics placed under penalties and disabilities, and a tax of forty pounds' weight of tobacco per head enacted for the support of the clergy. Protestant Dissenters were soon released from the penal laws, but these remained in force for Catholics, as did the church tax for the whole population, till the revolutionary war; a strange return to Lord Baltimore and the Catholic founders of the province. 


\section{LIFE IN SOUTH CAROLINA}

South Carolina, on the other hand, had a well-todo, well-educated, and powerful, though small, aristocracy. They drew their wealth from slave-tilled plantations of rice and indigo; but, unlike the Virginians, who loved a country life and hated towns, the South Carolina planter was also a merchant, and lived mostly in Charleston, which seaport had some reputation for social elegance and even intellectual activity. There were plain up-country farmers, however, even then in South Carolina, largely ScotchIrish, and many "poor whites." 1 There was a great deal of Huguenot blood, too, in the colony, though the tone of life was wholly English. Of Georgia, which was destined to run upon similar lines, there is no need to speak, as she was still in her infancy.

Now there had been no considerable immigration to America during the first half of the eighteenth century. The increase of population, though it had been rapid, was mainly native born. The chief exception to this was furnished by the Scotch-Irish exiles who since the beginning of the century had

1 South Carolina approximated more nearly to a West India colony. Its merchant-planters visited England more than any other American community. Charleston, though small, was tastefully built, and much admired by strangers. Trade restrictions, which in various ways irritated other colonies, did not affect $S$. Carolina. It was prosperous and growing wealthy, and had no reservations in its devotion to the British Crown. Colonial visitors from the north remarked on the richness of the dress of both men and women. The church and parish formed the unit of local government. Most of its higher class were sent to England for their education. Out of over a hundred American students entered at the Inns of Court during the years following the French war, nearly half, says a recent American historian, came from S. Carolina alone-small as she was; a significant test of her social development and intellectual alertness. 


\section{THE ULSTER IMMIGRANTS IN AMERICA}

been leaving Londonderry and Belfast in a steady stream. They had been introduced there, as every one knows, to fight the wild Celt of Ulster and to reclaim the lands he would not till, and they had done both with conspicuous success. Northeastern Ireland from a blood-stained wilderness had become a land of plenty, busy with the hum of trade and agriculture. But the English merchants were afraid of the new linen trade that was arising in Ireland, and the Anglo-Irish bishops did not like the Presbyterians. So the Irish linen trade was crippled as the wool trade had been destroyed, and the Presbyterian religion was treated on a par with that of Rome. The first piece of insanity was the work of the English Government, the second that of the Irish House of Lords, under the influence of the Irish bishops. In the latter case, the efforts to emancipate the Presbyterians, which the whole kingdom approved of, were defeated by the Anglican prelates in the Dublin Parliament by methods familiar enough to those acquainted with the performances of that strange assembly. The irony of the matter was not only that the Scotch immigrants had created industrial Ulster, and had covered themselves with glory as a loyal garrison at a great crisis, but that their crime lay in adhering to the form of Protestantism which was actually recognised by their persecutors as the established religion of the country their ancestors had left at the king's invitation!

These two crushing blows, falling near together, drove from a country that sorely needed them thousands of an industrious, hardy, virile, and God-fearing stock. It is said that a hundred thousand of these Ulster Protestants crossed the Atlantic 


\section{ULSTER BLOOD IN AMERICA}

in twenty years. ${ }^{1}$ Now the Irish Catholic immigration to America, it should be remembered, is a comparatively modern affair. Before the famine of 1848-49 it was inconsiderable. In the first half of the eighteenth century there was practically no such thing. The Scotch-Irishman, however, loomed always large as a strenuous and picturesque figure in that critical and picturesque period. To come of ScotchIrish blood is held to be of itself a good thing among Americans of colonial stock. The other sort of Irishman has, on the contrary, to face a prejudice almost inconceivable to the Englishman unacquainted with American social life-a prejudice aggravated, no doubt, by the conspicuous part which he plays in the more disreputable phases of American politics.

The Scotch-Irishman as a historical figure is regarded with no little respect, and justly so, as having been one of the stoutest contributors to the making of America. These early immigrants went scarcely at all to the New England colonies, landing principally at Philadelphia, and in lesser numbers at Charleston. They seemed determined not to place themselves again in the power of any Government, or again to trust themselves within reach of sectarian jealousy or unfriendly legislation. They found their way in no long time to the back-country of Pennsylvania on the north, and to that of the Carolinas on the

1 A fresh wave of Ulster emigration reached America just prior to the revolutionary war, when, the long leases under Lord Donegal and other great proprietors falling in, heavier fines for renewal and higher rents were asked than the old tenants would face. Catholic competition, however, maintained the price asked; and the Presbyterian exiles, full of bitterness, joined Washington's armies in large numbers. 


\section{THE SCOTCH-IRISH BORDERERS}

south, and threw themselves, in both cases, with consummate courage upon the forest-covered barrier which was then the Ultima Thule of Anglo-Saxon America. Being continually reinforced from Ulster, they gradually pushed on to the rear of the outermost colonial settlement along the base of the Alleghany mountains. Those from Pennsylvania crept slowly southwards into Virginia. Those from the Carolinas moved northwards in the same fashion, till the second generation of the original immigrants formed a continuous though thin line of settlements, stretching behind the Southern colonies from Pennsylvania to Georgia : a vanguard of virile frontiermen, who were equally handy with plough, axe, rifle, or tomahawk. They crossed the line of five colonies, but had little traffic with any, being, in fact, a people unto themselves, worshipping God in their own fashion, and educating their children to the best of their power, as they pushed their clearings deep into the shadow of the Alleghanies, and fought Indians so continuously that their austere natures took on, in some sort, the bloody traditions of the wilderness. If they lost something of their old-country morality and piety, they were of inestimable service in defending the Indian frontier and in later times conquering and settling the States that lay immediately behind it. To meet the Indian of that period in the woods upon equal terms required a special training and an exceptional hardiness. The average colonist was no match for him. The rangers of New England and the Scotch-Irish frontiermen of the middle and Southern colonies were almost the only men who could be relied upon to successfully face them in the woods upon anything like equal terms. The battle 


\section{BACKWOODSMEN AND INDIANS}

of the Great Kennawha, fought a quarter of a century later between a thousand picked borderers and a thousand Indians, is, in the opinion of the best living authority, Mr. Theodore Roosevelt, the first occasion on which a body of Americans defeated an Indian force of like strength in a pitched battle in the forest. I mention this to give some notion of the quality of the foe whom English and French alike had to face, and that ideas derived from the discrepancy in arms between modern civilization and barbarism may not obscure the tremendous difficulties of Indian warfare in eighteenth-century America.

The red man was not quite such a sure shot as the American borderer, but he was better at taking cover and at ambuscades than even the most accomplished backwoodsman. His discipline, too, which perhaps sounds strange, was better. He was rarely foolhardy, for a warrior's life was precious to the tribe. A maximum of damage to the foe with a minimum of loss to themselves was the recognised Indian principle; and when this was practised by crafty savages, who scarcely knew what fear meant, it told heavily against white men, who frequently threw their lives away in useless exhibitions of courage, and often refused to recognise inevitable defeat. It must not, however, be supposed that these Alleghany borderers were all Scotch Irishmen. They formed indeed the main element, but many Germans, as well as adventurers from the English settlements, joined their communities, sharing the perils of the border wars, and the scarcely less hazardous pursuits of an ever-doubtful and precarious peace.

Nor in these remarks on the various colonies have 


\section{COLONIAL GOVERNMENTS}

I said anything of their Governments or their relations with the Crown. The subject in detail is so complicated that an entire chapter would not cover it. Fortunately, however, there was such a general family resemblance between them in this particular that a page or two will be sufficient for what is necessary here. Some of the colonies were still proprietary, some had long ceased to be, others never had been. The difference was not so material as it sounds. The proprietors of colonies such as Pennsylvania and Maryland held them in fief from the Crown, as the English Palatinates of Durham, Chester, and the Welsh Marches had once been held, and they were subject to the same Imperial restrictions as their nonproprietary neighbours. In some colonies, therefore, the Governor was appointed by the proprietors; in others by the Crown, represented by the Board of Trade. He was generally an Englishman, though there are many instances of the honour being conferred on prominent colonists. In all cases, however, the Governor was supported by a council, usually twelve in number, appointed for life by the Crown, either directly or through himself as its representative. Besides this, and of at least equal importance, was an elective assembly. The Governors more often than not were represented in the colony by a deputy. They were by no means the dignified and hospitality-dispensing figureheads that now preside over our constitutional colonies. Their influence was very real, their seat a thorny one. They had to uphold the rights of the Crown in the face of constant attempts to encroach upon it. They were the dispensers of all patronage, though the home Government sometimes went behind them, 


\section{THE COLONIAL GOVERNORS}

and the colonial assemblies were frequently fighting for a share of it. The power of the purse lay with the assembly, which was apt to be niggardly to a degree in everything except the salaries of its own members. That of the Governor, too, was in their power, and they used this power freely to squeeze concessions out of him. It is scarcely too much to say that the legislature of every colony was in a chronic state of friction with its Governor. That the majority of these were men of very middling capacity goes almost without saying in a period when jobbery was the mainspring of all political patronage.

It is only natural, too, at a time when bribery and corruption were a matter of course in the mother country that the colonial Governor's patronage was often not above suspicion of similar methods, a state of things which the disappointed aspirants for local office, it need hardly be said, resented with much virtuous indignation. But appointments in those days were at least made from the class presumably best qualified to fill them, and even in the matter of honesty and public spirit would compare extremely favourably with the type of individual that the enlightened elector of modern New York or Philadelphia has to behold with resignation entrusted with the control of public affairs and the public purse. Nor were the colonial Governors by any means men always wanting in discretion and ability, as we shall see. But whether good or bad they were equally the object upon which the colonial burgess vented his suspicion, his discontent, his economic theories or his eloquence. It was the duty of the Governor to direct the Indian policy of the colony, 


\section{DIFFICULTIES OF CO-OPERATION}

to attempt combination with other colonies for offence or defence, and to do his best to see that the navigation laws, which forbad exports to any country but England and in any but English ships, were enforced. The duties of a colonial Governor, in short, were wearing and irksome ones. His salary was not usually a large one; at any rate, that of a Deputy Governor's was not: and he had often to fight his assembly for the full amount of even that modest remuneration.

It will now, I trust, be obvious how ill adapted were these disintegrated and self-absorbed provinces for effective and active combination. The vast distances that separated them, with the consequent lack of intercourse and communications, the abundant elbowroom that each still enjoyed, the jealousies and mutual prejudices which swayed them, the number of Governments that had to be consulted, with their narrow views and diverging interests, all conspired to make unity well-nigh impossible. It was fortunate that a handful of men were found who rose superior to these difficulties, or, to be more exact, saw at a glance their insuperable nature and aroused England to her danger before it was too late.

Let us now turn to Canada, the seat of French transatlantic power, and note the contrast she presented. Her southern boundary was roughly identical with that which now divides the Dominion from the United States, except as regards Acadia or Nova Scotia, a province which, though as yet peopled only by French peasants or habitants, had been for long under English rule. Coming westward, however, to Lake Ontario, we approach more debateable ground, and on passing the great Canadian fort at Niagara 


\section{CANADA}

and reaching Lake Erie the French could look southward over a vast country which both nations vaguely claimed.

So far as the French were concerned, this vagueness was now to assume more definite shape. But Canadian life at this time was mainly concentrated upon the banks of the St. Lawrence, having Montreal for its western limit and Quebec with the settlements immediately below it for its eastern and greater rallying point. With the numerous and scattered trading posts far remote from these old-established centres I will not now burden the reader's mind.

Though the colony was actually much older, as a substantial reality it can only be said to date from the immigration which Louis XIV. poured into it about the middle of the seventeenth century. Founded by clerics of the narrowest ultramontane school, in a period of over fifty years it had only accumulated a population of some 3,000 souls. The pioneering exploits of the Jesuit missioners form a heroic page of American history, with which, however, we have nothing to do here. It will be sufficient to say that everything had been made subsidiary to maintaining the religious dogma which had sent these early Fathers cheerfully to the stake and torture. The material result of this policy was disheartening, as may be gathered from the statistics quoted above. The feeble colony had, in fact, just contrived to hold its own by dint of hard fighting and the divisions of its Indian enemies, aided by the consummate diplomatic skill of the Jesuit pioneers.

But Louis XIV., while still young, had set himself with no little energy to rectify this state of things, and by dint of great inducements poured quite a large 


\section{COLONIAL ZEAL OF LOUIS XIV.}

stream of immigrants into New France. Officers and soldiers already out there were given grants of land. Peasants, selected with some care, were shipped out from Dieppe and Rochelle, more particularly from the former, as the Huguenot atmosphere of the Biscayan seaport alarmed the rigid Catholics of Quebec. No English colony had been either started or nourished by the Crown in this fashion. Convicts and the victims of unsuccessful rebellion were the only class of persons that the British Government had directly interested itself in transporting free to its colonies. A remarkable feature, however, of this paternally organized exodus to Canada was that families or married couples formed no part of it. Shipments of single men were forwarded to replace the bachelor soldiers whose swords had been turned into ploughshares, and single women gathered in the same fashion and not without care in the selection were sent out in succeeding shiploads. Under the immediate supervision of the Church these ex-soldiers and imported maidens, making choice as best they could, were joined together in the bonds of matrimony.

The girls were divided into two classes, demoiselles when possible for the officer settlers, while the humbler majority were allotted to the peasant soldiers. The king himself took a keen interest in this matrimonial mart, and was determined that Canada should be populated without loss of time. The young Canadian who remained single was pulled up before the authorities and made to show good cause for his backwardness, while those who continued obdurate were singled out for taxation and other unpleasant attentions, and their lives made generally miserable. If a father did not see to 


\section{SOCIAL EVOLUTION OF CANADA}

it that his daughter was married on arriving at a suitable age, he was soundly rated; and if he did not then take the hint, worse things befel him. On the other hand, the willing and blushing bridegroom was presented with a handsome bonus, and substantial premiums were offered to those who contributed most abundantly to the increase of population. A noblesse was part of the scheme, and a noblesse was consequently formed and gradually added to. It was not very easy to make one. The tendency to acquire and settle upon a large tract of land and gather dignity from the importance it gave, which distinguished the Anglo-Saxons of the more Southern colonies, had no counterpart in Canada. The French theory of aristocracy was somewhat the same; but the Frenchmen in Canada who had to play the part were generally not much better suited for it than was the country, which gave but small returns for most laborious work, and whose social life centred chiefly in one capital. A considerable number of the portionless, lower noblesse with which France swarmed had come out with their regiments to Canada; but in spite of inducements to stay, most of them, with the natural gregariousness of Frenchmen added to the chances of military renown, had returned to France. Blue blood and an old name, both in the France and England of that day, preferred the sword to the ploughshare or the monotony of the backwoods, save where really stirring adventure offered a compensation. American light literature, disregarding accessible evidence, and seizing with avidity on any point that breaks the democratic level of immigration, has exaggerated the origin of the French Canadian noblesse as it has done that of the govern- 


\section{CANADIAN NOBLESSE}

ing classes in the Southern colonies, and given them glorified antecedents which pale materially before the light of the simplest investigation. A small number, however, of the petty French noblesse, officers chiefly, were on the spot to form a nucleus, and to these were rapidly added others who had no claim to birth or blood, but only a little money or a little influence. What there was of an aristocracy in the English colonies had created itself by acquiring land, which, under an industrial system, was capable of giving comparative wealth and all that this means. There was no scheme of a noblesse, but its AngloSaxon equivalent had developed naturally, and was moreover of a practical and unmistakable description.

The Canadian noblesse, however, was an artificial affair, a forced matter in its inception, and though a very distinct order of society, acquiring but little substance. Just as an early Governor of Virginia wrote that everybody wanted to be a gentleman, so the seventeenth-century Governors of Canada reported that there was a universal craving to get a patent of nobility with its somewhat barren accompaniments, and assumptions of empty rank were common and easy enough in a country where outside the official class neither noble nor simple at that time earned much more than their food and clothes. Seigneuries large in extent, covered with dense forests, cleared only on the river front, formed the unit of life outside the few towns. The log-houses of the peasant tenantry extended along the river front, while the scarcely superior mansion of the seigneur, with the inevitable mill and not seldom a parish church, stood close at hand. Trifling rents, and those paid, when paid at all, in kind, just served to keep 


\section{CANADIAN SEIGNEURIES}

this strange species of nobleman and his family in food and clothes. Even this result was not always achieved, kings of France having more than once to send out provisions to save their transatlantic nobility from starvation. Sometimes even their wives and daughters worked in the field. Whatever his origin, however, once ennobled, the seigneur was not at liberty to follow any trade or calling, and it is small wonder that "sloth and pride," according to contemporary French writers, were his distinguishing points. But these very attributes and the conditions of his life, while inimical to success in peace, made him formidable in war. The ragged Canadian gentilhomme, inured to the chase and a stranger to luxury, equally at home in the trackless forest or on the boiling rapid, was the beau ideal of an irregular soldier. Brave, hardy, adventurous, and somewhat callous to human suffering, he was an admirable leader to a peasantry who shared most of his qualities and were only less ready than himself to answer the call to arms. ${ }^{1}$

But by the period we are treating of Canada had made some advance in prosperity, and in normal times was at least self-supporting. There were a few prosperous seigneuries and a handful of well-to-do seigneurs, though whether rich or poor the pride of caste, greatly aided by official encouragement, had been maintained. But neither seigneur nor habitant had any share in the government of the country, which was wholly autocratic.

In the city of Quebec, unsurpassed for its pride of pose by any capital in the world, was centred the

1 Dr. Kalm and La Hontaine, among others, have left interesting pictures of Canadian life as they saw it in the middle and the beginning of the eighteenth century, respectively. 


\section{GOVERNMENT OF CANADA}

power to which all Canada yielded unquestioned obedience. There, in the chateau of St. Louis, upon the famous rock, whence cannon frowned over the spires and gables of church and monastery, sat the all-powerful Viceroy of the King of France. Nor was he, like the governor of an English province, commissioned to this important post with little or no regard to personal capacity. On the contrary, much care was usually exercised in his selection. He was nearly always a fighting man or statesman of approved ability; sometimes he was both. To speak of him, however, as all-powerful is perhaps hardly accurate. It would be more exact to describe him as the leader of a Triumvirate, of whom the other members were the Intendant and the Archbishop. The former of these two functionaries was a person of legal acquirements rather than of rank. He looked after the finances, and to some extent shared the government with his chief. He did much of the confidential correspondence of the colony with the home authorities, and may be described as a check in the king's interest upon the absolutism of the Governor. The third member of the trio, the Archbishop, guarded the interests of the powerful Ghurch of Canada, with its monasteries, convents, colleges, and wide landed possessions, and kept watch over that supremacy which it regarded as vital to the salvation of Canadians and in some sort its due on account of the great share it had taken in the early struggles of the colony. To this triumvirate was joined in times of stress a military commander, as will be amply demonstrated later on. However much these officials might disagree among themselves in times of peace, when outside danger 


\section{THE FRENCH FUR TRADE}

threatened they sank their differences for the moment, and showed a united front. In Government circles, the ecclesiastics and perhaps the Governor himself excepted, a system of monstrous corruption flourished. The fur trade, which formed the real wealth of the colony, though little enough of it remained there, was practically a Government monopoly. It employed perhaps a third of the Canadian population, at bare living wages, and made the fortune, by means of well-understood devices, of a small handful of officials, who hurried back to France with their gains. Supplies, too, as well as large sums of money, were continually pouring into Canada for public purposes, and were manipulated by the official clique at Quebec, with a corrupt disregard for the public welfare that even for those days was remarkable.

In spite of all this, however, a fine daring and much patriotic zeal animated the French Canadian people as a whole. Bigoted, ignorant, and superstitious, they marched against English Protestants or Indian savages as upon a crusade. They had infinite belief in their superiority to the former, and a childlike faith in anything told them by their ecclesiastics, who beyond a doubt severely tested their credulity. The spacious West, to which they all had access at one time or another, was the finest of schools for backwoods warfare, while the habit of obedience to social or military superiors went hand in hand with an unquestioning loyalty to their Church. They had been accustomed to ravage the New England frontier, and having often got the better of the industrious Puritan farmer had imbibed some contempt for the colonial Englishman as a soldier, 


\section{BIGOTRY TOWARDS PROTESTANTS}

which an extraordinarily boastful temperament made appear even yet more blatant. The impecunious, idle, and numerous noblesse were always at hand to lead in every kind of adventure. Numbers of them lived almost wholly in the woods among the Indians, adopting their dress and costumes, egging them on against the English settlements, and frequently leading them on their bloody raids.

What might have happened had not the fatuous bigotry of the Canadian priesthood repulsed the Huguenot from their shores, one almost shrinks from contemplating. If the French and Canadian Government had been as tolerant and far-sighted in this particular as in some others, and given an opportunity to the most virile blood of France, which for so many generations invigorated that of other nations and their colonies, history must have been written differently. But, compared with that steady, plodding subjection of the wilderness by the British colonist, Canadian civilization was a failure. One can have nothing, however, but admiration for the courage and enterprise with which its people faced the unknown in the trackless, perilous path of the fur trade. Montreal was the depôt and startingpoint for all concerned in it, and stood near the Western limit of civilization. Frontenac, where Kingston now stands, was the first great outpost in the forests beyond. Niagara, whose name indicates its position, was a still remoter station of great import, and Detroit, yet further on, was a still larger one. The stormy waters of Lake Superior were familiar even then to the French voyageur, whose canoe crept along its gloomy shores and exploited its lonely bays. Even this, however, seems almost 


\section{ENTERPRISE OF FRENCH TRADERS}

as nothing to the astonishing remoteness at which stockaded forts held by small bands of hardy Frenchmen were to be found. To many of us in middle age it seems only yesterday that the man who settled on the prairies beyond Fort Garry (now Winnipeg), was regarded as a veritable pioneer. An air of mystery still surrounded the "Great Lone Land," and one gazed on the grey tombstones ${ }^{1}$ of Scottish traders of the early nineteenth century with something like awe. But the French were here trying to choke the infant efforts of the Hudson Bay Company quite early in the century before. They had not only stations on the Lake of the Woods and the Red River, but actually on the Saskatchewan itself. In days when a letter sometimes took a week upon the short route from New York to Baltimore in the then heart of colonial civilization, the aloofness of these old French outposts is verily calculated to stagger the imagination.

But we shall have little to do with them here, and before closing this chapter must return to the banks of the St. Lawrence to touch for a moment upon the military strength of Canada. The militia, in which every male between sixteen and sixty served under compulsion, were reckoned at this time as between 15,000 and 20,000. There were also in regular garrison some 2,000 troops of the colonial marine, officered and mostly raised in France. There were usually, too, some troops of the line in the colony, their numbers varying of course with the state of current events. Of the number of Indians utilized in war by the French it would be vain to hazard any estimate.

' In the churchyard of the old St. John's Church, near Winnipeg. 


\section{INDIANS}

Save for the celebrated "Six Nations," whom neither French diplomacy nor French successes could ever wholly win from their neutrality and English sympathies, ${ }^{1}$ most of the Indian tribes ultimately espoused their cause. There were a large number, too, of Mission Indians, nominally Christians, and bound to the interests of the French, being under the influence of their priests. But of the numerous wild tribes to the westward and the fragments of the neutral nations nearer home, it would be superfluous to attempt a classification. To do so would be to thrust upon the reader a mass of detail which he is probably neither prepared nor inclined to digest, even if it were essential to the understanding of the great Anglo-French struggle, in which I hope to engage his interest.

1 Originally "called the "Five Nations," consisting of the Mohawks, Oneidas, Onondagas, Cayugas and Senecas. They occupied the country stretching from Albany to Lake Ontario, in the order named. 


\section{CHAPTER II}

T was in the year 1747 , just prior to the peace and 1 treaty of Aix-la-Chapelle, that De la Galissonière arrived in Canada as its Governor. Like many of his predecessors, he was a naval officer, being, in fact, the very commander who, a few years later, opposed Byng in the action off Minorca which brought disgrace and death and immortality to that unfortunate admiral. Though of an ill shape, amounting almost to deformity, the new Governor was a man of singular shrewdness and ability, and regarded the future of North America with anxious foresight. For a moment he was chiefly disturbed at the activity of the small and remote settlements of the Hudson Bay Company, but in a short time the vaster and more direct issues which brooded over the West commanded his whole attention. We have already seen how long was the arm that France thrust out to grasp the fur-bearing regions of the North and North-West. But to the southwards, to that vast fat country which in modern parlance would be called the middle West, she had as yet turned little of her attention. With its head resting on the great Canadian lakes and its feet upon the small French settlement of New Orleans. and the Gulf of Mexico, this region was still, if we except that unconsidered factor, the indigenous inhabitant, a no- 
man's land. An ocean of foliage, almost unthinkable in its immensity, and only broken at intervals by the smooth sheen of noble rivers, the white gleam of turbulent streams, or the scarcely noticeable clearings, where faint smoke-wreaths marked an Indian village, it patiently awaited the struggle that such a virgin empire at such a strenuous period was quite certain to provoke.

Viewed by the light of modern times, all other territories in dispute, or ripe for it, between the two nations, seem to sink into insignificance before this great American hinterland. ${ }^{1}$ Nor, of course, was it merely this West of 1747 , this Mississippi basin, that was the prize, but those greater and only less fertile realms beyond, which in the days I write of had hardly dawned on the vision of the wildest dreamer.

It is a curious reflection that a cork thrown into a stream which on an ordinary map of the United States would appear to rise upon the very shores of Lake Erie, will eventually float out through the mouth of the Mississippi at New Orleans into the Gulf of Mexico. Now both Lake Erie and New Orleans were French, and this network of converging streams pouring southwards formed a link between them, practically cutting North America in twain. It was this immense, well-watered domain, lying between the northern and the far southern settlements of France, which filled the mind and fired the ambition of Galissonière and others no less important than he. Their aims, which now began to assume definite shape, were to form a far-extended line of

${ }^{1}$ India lends itself in no way to comparison with the settlement of new countries. 


\section{CLAIMS OF FRANCE AND ENGLAND [1749}

forts from the headwaters to the mouth of the Ohio River; and to gain over the Indians of all this region, both by energetic intrigues against the English, and, what was still more effective, by a military occupation of it and a display of force which would be sufficient to intimidate all European interlopers. This achieved, it was thought not unlikely that a fresh wave of French immigration might give solidity to the occupation, and that the English would thusso they dared to hope-be permanently hemmed in behind the Alleghanies, which formed a continuous and formidable rampart between this new country and the thirteen colonies.

Both nations claimed the Ohio Valley, the French on account of La Salle's discovery of the Mississippi a century before; the English for the more tangible reason that the land of promise lay immediately behind and adjacent to their own colonies, and that their traders had been for long accustomed to cross the mountains in considerable numbers. But claims which clashed so hopelessly could not be settled by treaties, and the French were by a long way the first to recognise that they would be settled by the sword. The treaty of Aix-la-Chapelle could do nothing to determine such hopelessly conflicting views, though Commissioners sat for months endeavouring with much futile diligence to adjust the comparatively simple question of international boundary lines in Nova Scotia and the adjoining mainland.

It was not, however, till the summer of 1749 that De la Galissonière started the first French expedition to the Ohio, a purely prospective one, and only just strong enough to protect itself from possible Indian hostilities. It comprised some fourteen officers and 


\section{9] THE OHIO FRENCH TERRITORY}

cadets, twenty French regulars, a hundred and eight Canadians, and a few Indians.

Leaving Montreal in early summer, they passed up Lake Ontario, and carrying their canoes round the falls and rapids of Niagara, pushed up Lake Erie as far as the present village of Portland. Here they landed, and, laden with their boats and packs, scaled the lofty ridges on whose further slopes the fountain springs of the Ohio basin gather in the now familiar waters of Chatauqua Lake. After infinite toil through pathless forests and down rocky shallow streams, they reached within a month the broader current of one of the forks of the Ohio, now known as the Alleghany. A French captain, De Céloron, was in command, and among his portables he carried a number of leaden plates bearing significant inscriptions, and as many tin shields engraven with the arms of France. On reaching the Alleghany River he buried one of the first of these in the ground, and nailed one of the latter to a tree, formally proclaiming at the same time that he reasserted the dominion of the king his master over the whole region. The words inscribed upon the leaden plates ran as follows: "Year 1749 in the reign of Louis XV., King of France. We, Céloron, commanding the detachment sent by the Marquis de la Galissonière, Commandant General of New France, to re-establish tranquillity in certain Indian villages in these cantons, have buried this plate at the meeting of the Ohio and Tchadakoin this 29th July, as a mark of the renewal of possession which we had formerly taken of the aforesaid river Ohio and all its feeders, and all territory upon both sides of the aforesaid streams as former Kings of France have 


\section{THE FRENCH ON THE OHIO}

$[1749$

enjoyed or ought to have enjoyed, and which they have maintained by force of arms and by treaties, especially by those of Ryswick, Utrecht, and Aix-laChapelle."

Within living memory more than one of these plates have been cast up by the rage of streams that now turn the mill-wheels and bear the commerce of a stirring Anglo-Saxon life. Grim spectres, as it were, from the grave where lie buried and forgotten the splendid dreams of the old pioneers of France, they may still be seen amid the curiosities of museums, and pondered over as rare object-lessons on the vanity of human hopes.

There is no need here to dwell in detail on the doings of this advanced guard, these heralds of an approaching conflict, whose gravity they themselves so little realized as they paddled their bark canoes down the buoyant streams of "La belle rivière." Indian villages, breaking the dense wall of bordering forests, by the river side, they found in plenty, where Delawares, Shawanoes, and Mingoes dwelt, with a fat and fertile country spreading all around. Buffalo browsed in rich meadows of blue grass and wild clover, while elk and deer ranged through stately forests whose timber spoke of a soil more generous and a clime less stern than that which they had left on the banks of the St. Lawrence. Everywhere De Céloron and his followers proclaimed their peaceful intentions-a very necessary precaution, in truth, for so weak a force-and protested that their only object in undertaking so toilsome a journey was to warn their Indian brothers of the treacherous designs of the English. Everywhere, however, to their chagrin, they were received without enthusiasm, and 


\section{9] INDIANS SHOW NO CORDIALITY}

sometimes in a fashion that threatened to become serious. In almost every village they found a handful of English traders, whom they warned off as trespassers on French territory, producing in justification of their course a written treaty that was capable of almost any sort of interpretation. The Indians showed no disposition to be rid of the traders, though it was not worth the latter's while to resist an order that could be laughed at the moment the French had turned their backs. So everything went off pleasantly. The Indians drank a good deal of brandy at the expense of their father Onontio (the French king), and listened stolidly to lengthy orations in which they were assured that the English were their real foes, and that it was not trade they desired, but land, which was perfectly true so far as the colonists collectively were concerned, for there were land companies at that very moment blossoming out both in Virginia and Pennsylvania. The French, so the Indians were assured, were their true and only brothers, while their father Onontio, if they would only believe it, was a very paragon of parents. More tin shields were nailed to trees, and more leaden plates buried, the last of them by the banks of the Great Kennawha, in the present State of West Virginia.

After a toilsome pilgrimage, accounted by the travellers as not less than 3,000 miles, De Céloron, with a somewhat diminished company, arrived once more at Montreal, possessed of the uncomfortable conviction that leaden plates and tin shields, and the blessings of Onontio would go a very short way towards securing this earthly paradise for France. It was a lamentable but undeniable fact, he declared to the 


\section{DE CÉLORON'S REPORT}

new Governor of Canada, Jonquière, who had arrived in his absence, that the English traders could easily undersell their own, that rivalry in this particular was impossible, and that the Indians were everywhere well disposed towards the English. The latter, he declared, must at all hazards be kept upon the east of the Alleghanies, and the Ohio Valley preserved from their intrusion. De Céloron had, in fact, despatched during his wanderings a civilly worded letter to the Governor of Pennsylvania, from whose borders came the majority of traders encountered by the French, expressing surprise that the English should be making so free with territory that all the world knew was the property of his most Catholic Majesty. But if His Excellency of Pennsylvania ever received it, it is quite certain he never vouchsafed a reply. This expedition, though we have passed over it lightly, was geographically and politically an extremely important one. But the English colonists knew almost nothing of it. Even their few farsighted leaders scarcely took notice of it. But with the French it was the prologue of war.

We must leave the effects of the De Céloron expedition to simmer in the minds of the rulers of Canada, while pausing for a page or two, even thus early, to say something of Acadia or Nova Scotia, that outlying bone of contention between the two nations in the North. A glance at the map will show the reader how very nearly an island is this important peninsula. The narrow isthmus which connects it with what is now New Brunswick was then the boundary across which the troops of France and England watched each other with no friendly eyes from their respective forts. 
At the north-east of Acadia, only severed from the mainland by the narrow gut of Canso, lay the island of Cape Breton, a name once as familiar to the world as the Cape of Good Hope, but now almost unknown. Its fame rested on the great fortress of Louisbourg, which with its considerable town and ample harbour dominated the North Atlantic, and was styled the "Dunkirk of America." All Acadia had been handed over to England at the Peace of Utrecht in 1713, with the exception of this little island of Cape Breton, or in other words Louisbourg. The latter, during the late war in the year 1745, had been stormed and captured in spirited fashion by a force of New England militia under Peperall, acting in conjunction with Admiral Warren and an English fleet. It was restored to the French, however, three years later at the treaty of Aixla-Chapelle, amid the loud protestations of the few in England who were conversant with the politics of the North Atlantic-protestations fully justified by the immense stress laid upon its restoration by the French. The population of Nova Scotia consisted of a few thousand French-Canadian habitants, who chiefly occupied the more fertile spots on the western coast which looked across the Bay of Fundy to the even less populous mainland. There were also, as already indicated, two or three isolated forts where small detachments of British regulars or Colonial militia under a British Governor maintained an existence of appalling monotony and of almost unexampled seclusion from the outer world.

Everything conceivable had been done, both from motives of policy and humanity, to reconcile these outlying French-Canadians to British rule. They 


\section{THE FOUNDING OF HALIFAX [1749}

had now been recognised British subjects for nearly forty years, and had been consistently treated in a fashion so magnanimous as to be the despair of the French, who through the agency of their priests, backed by their bloodthirsty battalions of so-called Indian converts, had laboured tirelessly to promote discontent with British rule; but of this there will be more to say later. It will be sufficient to state here that the French, with their renewed occupation in greatly increased strength of Louisbourg, had so encouraged and accelerated these evil efforts throughout the province that it was deemed necessary to create a counterpoise, and Halifax was founded upon the eastern shore. It was the only instance, and, I think, remains so, of a British colony of free men founded by the Imperial Government for a definite and Imperial purpose. Surveys were made, the site of a city selected, and offers of land, of temporary maintenance and arms were advertised in England, with special inducements to the many officers and soldiers disbanded after the late war. In July, 1749, three thousand souls-men, women, and children-were landed on the shores of Chebucto Bay. Others followed, and in a short time, with much less of the trouble, hardship, and sickness that usually attends such wholesale ventures, the town of Halifax arose. The nucleus of British settlement was now introduced, that, immensely increased thirty years later by the exiled loyalists of the American Revolution, was to make Nova Scotia a great and prosperous British province. The French settlements lay, as I have said, upon the western side of the peninsula. The Acadians, who there grew hay and oats and apples upon a limited 


\section{9] CONTENTED ACADIANS}

scale, were sunk in ignorance and superstition. They were thrifty, however, fairly industrious, and of themselves only anxious for an obscure and peaceable existence. ${ }^{1}$ Their English Governors had interfered with them in no way whatever, not even taxing them in the lightest degree. The French authorities, with the recovery of the province always in view, and in consequence keenly interested in keeping disaffection alive, regarded this extreme leniency with something like dismay. They went so far as to complain that the British Government condoned even the very crimes of these simple peasants. One most necessary token of submission, however, their new masters had made, or rather endeavoured to make, a point of, and this was the oath of allegiance to King George. To the peasantry themselves, born for the most part in remote seclusion and ignorant of the sentiment, probably of the very meaning of the word patriotism as regarding their mother country, this would in itself have been a small matter. But of the priests they stood in proper awe, and the priests were instructed to spare no pains in endeavours to prevent their flocks taking the obnoxious oath. Unscrupulous energy was shown upon the one side; too much forbearance upon the other by the handful of bored and good-natured soldiers who represented England. For the first thirty years, however, these clerical agents from Canada were not so actively mischievous ; the greater part of the thinly scattered population

1 The Acadians were not fond of the axe. They made little inroad on the forests which covered Nova Scotia, but diked in the marshes which fringed the sea-coast at certain places, and cultivated the reclaimed land. 


\section{PRIESTS PROMOTE DISCORD}

took some sort of oath of allegiance, and the land had peace.

Then came the great European war, which was chiefly marked in North America by the capture of Louisbourg at the hands of the New Englanders in 1745. This notable achievement sent a passing quiver of excitement through the dense forests of Acadia, even to the villages on the Bay of Fundy. The Canadian missionaries renewed their efforts, which were met with a fresh show of activity in enforcing the oath. But so far no very tangible evil had come of all this. The Acadians were not put to the test; they were far removed from all scenes of racial strife or discord, and among their diked-in meadows and orchards continued to propagate in peace and rude plenty the most reactionary and ignorant breed of white men on the North American continent.

When Louisbourg was given back to the French, however, and some vague claims to the northern shore of the province as the only winter route to Canada were put in by them to the commissioners appointed at the treaty of 1748, all was again agog. The founding of Halifax in the following year, and the advent in force of the dreaded British settler, though on the further shore, seemed to demolish all hopes of French supremacy in the future. England might annex and rule, for their very great content and infinite happiness, the French American colonies, but she might get tired of such an unprofitable business. It was not likely, however, that Great Britain would ever allow a province, whither she had deliberately invited her own people, to pass again into the hands of a Government who hounded even their own Protestants, like lepers, from their gates. 


\section{9-53] DUPLICITY OF OFFICIALS}

Such activity was now shown in stirring up the hitherto happy Acadians, both at the lately restored Louisbourg and at Quebec, that the British authorities felt that after forty years of indulgent treatment the hour had now come to demand who were their friends and who their foes. Any Acadians who might object to taking the oath of allegiance to King George had been granted ample liberty to remove their effects to the adjoining territory of Canada. Most of the few, however, who had gone had been driven there by priestly intimidation. War seemed again in the air, and war this time of a more serious kind, for America. Cornwallis, uncle of the ill-fated general who surrendered thirty years later to Washington at Yorktown, had just come out as Governor of Nova Scotia. He was an able and sensible young man of thirty-five, and of a kindly disposition, but he decided that the Acadians must once and for all be put to the test of a full and binding oath of allegiance. Most of them had been actually born British subjects. It was thoroughly understood in Canada that, if left to themselves, they would ask for nothing better than to continue such; so the cruel system of intimidation was renewed with redoubled zeal.

The Governor of Canada and the Commandant of Louisbourg were the chief wire-pullers, and their correspondence revealing their precious schemes is extant. If war was inevitable, the French were anxious to defer it as long as possible. Peace was to be outwardly observed, even to effusiveness. The official pens of the French commanders grew almost affectionate when addressing their brother-dignitaries in Halifax and the British forts. Their letters 


\section{LE LOUTRE IN ACADIA [1749-54}

to the agents of this secret policy almost joked about these diplomatic falsehoods, as they gave precise instructions for the discord that was to be spread among the Acadians and the scalps that were to be torn from the bleeding heads of English settlers by Micmac Indians in French employ. The two leading points in their policy were to frighten the Acadians from taking an oath of allegiance which their simple faith might lead them to regard as binding, and to frighten the newly arrived English settlers out of Nova Scotia. But above all, they wrote to each other, it was imperative that they should not be suspected of such designs.

Their chief agent for carrying fire, and sword, and misery among the hitherto contented Acadians, was an unscrupulous scoundrel called Le Loutrean energetic, able, but fanatic priest, whose hatred of the English was only equalled by his heartless cruelty to his own people. He had many zealous abettors under his orders, priests of the cold-blooded and bigoted stamp, though even they recoiled sometimes from their leader's methods. Short of physical force, religious terror was the only engine by which the Acadians could be driven. It was this agency, one which Canadian priests so well understood, that had all along been utilized. But now the screw was to be turned on in pitiless and relentless fashion.

Any Acadians who should take the proffered oath were promised inevitable damnation in the world to come-an awful reality to the trembling, credulous habitant. To take an oath of allegiance to a heretic king was represented as the most hideous of all sins. They were assured, too, that the English settlers at 


\section{9-54] ACADIAN TROUBLES}

the far edge of a hundred miles of unbroken forest would take away their lands. Those who showed signs of risking their salvation, and of judging the English by their past deeds, were threatened with a visit from one of the many bands of Micmac Indians with which Le Loutre now filled the woods. Attacks upon the English settlers pushing out from Halifax were represented as a religious crusade. The murder of straggling soldiers from the British forts was extolled as a meritorious action. The so-called Christian Indians were hounded on till the environs of Halifax became the scene of daily murders, and all this was in peace time! Proclamation after proclamation was sent out by the English authorities, calling on the people to take the oath, recalling their past treatment and promising them a continuation of it. The wretched Acadians, grovelling with superstitious fear, and steeped in the lies poured daily into their ears as to the British intentions, were in a pitiable position. There was no question of patriotism in the ordinary sense of the word. It was sheer terror, physical and spiritual, that paralyzed them. A shade more of intelligence on their part would have righted the whole matter, and the misleading hexameters of Evangeline would never have been written. Long before the last of the many ultimatums sent by the long-suffering English governors, hundreds of Acadians had abandoned their homesteads and fled to the strange and unsympathetic settlements on the Canadian mainland or to the sterile rocks of Cape Breton. Hundreds more, bewildered and despairing, had fled to the woods, mixed with the Indians, shared in their bloody raids, and become irretrievable outlaws. 


\section{ACADIAN TROUBLES}

No word of pity for these unhappy people, so far as we know, passed a French official lip. A prosperous village that showed signs of preferring the familiar and indulgent rule of the Government under which most of its people had lived and flourished all their lives was fired by Le Loutre's own hand to drive them into exile. The tension and rivalry existing between England and France at this time in America admitted of no half-measures. The French fort of Beausejour scowled across the narrow isthmus at the British station of Fort Laurence, and formed an admirable base for the devilries of Le Loutre. Since the re-occupation of Louisbourg by the French, the latter had become the stronger military influence on the north-east coast, and they fondly looked forward, when war should break out, to the recapture of Nova Scotia. That the manhood of 12,000 hardy peasants would be an invaluable aid goes without saying, and accounts for, though it does not excuse, these untiring efforts to destroy the harmony between the Acadians and the British Government. Monckton, of whom we shall hear again, succeeded Cornwallis as British Governor. Hobson and Laurence (of expatriation notoriety) followed, all excellent and kindly men. The ethics of the eighteenth, or perhaps even a later century under similar conditions, could not be expected to tolerate the persistent refusal of nearly the whole population of a legally possessed and leniently administered province, to swear full allegiance to their lawful king at a vital crisis. The whole story from 1747 to 1755 is sad enough. It is the blackest blot on French transatlantic history, and stains the memory of De la Jonquière and Duquesne, who 


\section{9-55] DE LA JONQUIÈRE GOVERNOR}

permitted their innocent fellow-countrymen to be made the tools of a dishonest policy, to be heartlessly sacrificed, and then ruthlessly flung away. The notable deportation of 8,000 Acadians in 1755, taken by itself, is not easy to defend; but who reads of or cares anything for the years of forbearance under ceaseless provocation, which at last broke down before the deadlock which at a critical period faced the English Government? It is a poor consolation, too, to remember that of all the various points to which these unhappy emigrants found their way, it was among their fellow-countrymen in Quebec that they met with least sympathy and kindness, while the greatest measure of compassion, and that of a practical kind, was found among the arch-heretics of New England. All French writers of that day unite in testifying to the complete indifference shown towards the Acadian refugees by their countrymen, and all repudiate the methods of Le Loutre.

It is satisfactory to know that this unprincipled fanatic was eventually caught by the English on the high seas, and was a prisoner for eight years in Jersey Castle under an assumed name. A story runs that a soldier of the garrison, who had served in Nova Scotia, recognised the monster as having once ordered him to be scalped, and tried to stab him with his bayonet. The soldier's rage was so uncontrollable, that he had to be transferred to another garrison. But we have of necessity been anticipating somewhat, and it is a relief to turn from these poor and underground methods of combating destiny to the more honest operations on the Ohio.

In the year 1749 De la Jonquière succeeded Galis- 


\section{DUQUESNE ARRIVES}

sonière as Governor of Canada. He succeeded also to his policy of keeping the English upon the eastern side of the Alleghanies. But he was not fated to carry it much further forward; for though he ruled over Canada for nearly two years, the rival nations remained at peace, and it required some exceptional audacity to take the risk of setting the world on fire. De la Jonquière died early, in 1752; and, after a brief interval, the Marquis Duquesne de Meneval came out in his place. He was descended from the famous naval commander of that name, was of haughty mien, a strong disciplinarian, and zealous to a fault in all military concerns. He exacted full service from the militia, about 15,000 strong, drilled and organized them, together with the 2,000 colonial regulars or troops of marine, and worked both arms of the service with much assiduity for nearly two years in his determination to make them a thoroughly efficient force.

In the summer of 1752 , when the rivers and lakes had shaken off their load of ice, Duquesne made ready for the first act in the coming drama, and sent out the expedition that was to begin fort-building in the Ohio Valley, the disputed territory. Like Galissonière's less direct challenge three years previously, Duquesne's stronger cohorts paddled up to Lake Erie, but chose on this occasion a better landingplace, at a spot where the town that takes its name from the lake now stands. There were here, however, twenty miles of rough watershed to be surmounted, and the difficulties of carrying their impedimenta over it were so great as to exhaust the patience and capacities of the younger officers and the vitality of their commander, Marin, who died 


\section{2] THE FRENCH BUILD FORTS}

from his exertions. He was an old and capable officer, and his loss was greatly felt. A successor was sent forward by Duquesne-if not so old as Marin, a veteran in experience, and an explorer of the western plains, one Legardeur de St. Pierre. The difficulties of their progress were increased by loads of useless trappings that were purchased for corrupt reasons by the officials who made money out of commissariat transactions. Two forts were built, one at Erie on the lake, another at the head of Ohio navigation, known as Fort le Bœuf. This was enough to impress the Indian tribes with ideas of French determination and English apathy; an earnest rather of what was coming than a farreaching movement in itself. At the same time it was quite enough to arouse the British authorities to their danger, and to call for explanations, which hastened on the crisis.

Two colonial Governors stand out pre-eminently at this moment, Shirley of Massachusetts, and Dinwiddie of Virginia. The former was a nimbleminded, energetic, capable man of affairs, who had thoroughly identified himself with the interests of the colonies, and had served on the boundary commission of the treaty of Aix-la-Chapelle. The latter was a shrewd, blunt Scotchman, a deputy of Lord Albemarle's, the titular Governor, whose agreeable manners, Lord Chesterfield tells his son with admiration, were the sole reason of his being the greatest sinecurist of his day. It was as well the homely Scotchman, though the Virginians did not like him, stood in the shoes of his exquisite employer, for he was a faithful and alert watchdog over British interests, while Americans should be for ever grate- 


\section{APATHY OF BRITISH COLONISTS [1752}

ful to him for giving Washington his first opportunity.

The lesson of De Céloron's expedition of five years previously had been apparently lost on the colonies, since officially they had done absolutely nothing to resent his claims. Traders continued to cross the Alleghanies, ${ }^{1}$ while two land companies, in Pennsylvania and Virginia respectively, had acquired grants in the disputed territory upon certain conditions, and had gone so far as to send well-known frontiermen to locate them. No thoughts of the French, however, seem to have disturbed these sanguine speculators, nor had any steps been taken to resist them. A good deal of quarrelling had taken place between the rival companies, whose pioneers in the woods had so traduced each other that the Indians beheld the English not only unprepared for war, but apparently at loggerheads among themselves. Moreover, it was quite evident to them that the French were right, and that it was land the British were after, not Indian friendship and trade. The more friendly Indians begged these emissaries of the two companies to build forts at once, but their principals on the seaboard, with characteristic and persistent blindness to the French movements, disregarding all warnings, gave no heed to the advice.

The Governors of some of the colonies, however, and in particular the two already indicated, were keenly alive to this activity of the French on the

1 The Alleghany chain is of considerable though varying width. Its altitude lies between 2,000 and 6,500 feet, increasing as it travels south. Its highest points are in the West of Virginia and North Carolina. 


\section{2] ENCROACHMENTS OF THE FRENCH}

Ohio, and despatched upon their own account special envoys. But from the very fact of these being the emissaries of the Governor and not of the colony, the legislatures paid no regard to the significant tidings they brought back. For at this time, as at most, almost every colonial Assembly had some special quarrel, usually one of a trumpery nature, with its Governor. But however trifling was the particular question in dispute, it was that of the hour, the topic of the tavern and the coffee-house, the planter's verandah, the farmer's kitchen, and it loomed much larger in the local mind than fantastic theories of remote French enterprise which might possibly be ripe for consideration when their children's children stood in their shoes.

New York and New England were more enlightened, but the former at least had some excuse for declining further obligations, since she had the Six Nations on her flanks to keep in humour, and had, moreover, to protect the route to Oswego on Lake Ontario, the only English post upon the northern lakes and a continual irritant to France.

The French were greatly encouraged by the sight of such indifference. It almost seemed as if the English were content with their seaboard territories, and were really inclined to give their rivals a free hand behind the mountains. So by slow steps they erept onwards down the feeders of the Ohio. By stealthy methods-the expulsion of English traders, the punishment of unfriendly Indians, the assumption of supreme control-they worked upon the imagination of the savages, who, seeing such vigorous conduct neither resented nor resisted, began to regard the French as the rising, the English as 


\section{ENCROACHMENTS OF THE FRENCH $[1752$}

the declining power. English interests beyond the Alleghanies were wholly represented by individual traders, for whom it must be said that they had often gained, not less by their courage and ability than by the cheapness of their goods, much influence over the Indians. But they were, after all, mere private adventurers, and few in number, while the French, who were now showing their teeth so unmistakably, had the evident backing of their Government behind them. There was nothing the Indian respected more than an energetic show of force, except the actual use of it, and those tribes who were friendly to England were now sadly depressed, and fully believed that her power was on the wane.

The desire of the French Government to support their Canadian deputies was by no means free from a suspicion of the motives that animated some of these forward patriots. It was not the legitimate ambition of the capitalist for new fields, such as rouses the ire of the Little Englander today, that gave them pause, but the official peculation that in every fresh expedition saw another opening for illicit gain. Bigot, the last and most notable Intendant of Canada, led the gang, and made scarcely concealed mockery of those of his nominees who failed sufficiently to profit by his patronage. But side by side with this system of unblushing robbery, which stunted and impoverished the colony, went a great measure of patriotism, considerable military ability, and a mortal hatred and jealousy of the English. Duquesne wrote home to his Government that the country "was full of rascals," but it was also full of soldiers. 


\section{3] GOVERNOR DINWIDDIE MOVES}

Dinwiddie, the shrewd Scotch Governor of Virginia, was the first to move, and this he could only do by way of protest, since he had no forces worth mentioning and no money to pay the handful that he had. It is a strange coincidence that the agent he selected for the business-the first British soldier, in fact, who went out formally to proclaim King George's title to the West-should have been George Washington. The young Virginian was at this time only twenty-one, a major in the colonial service and adjutant-general of the Virginia militia. In the opinion of Dinwiddie, an opinion which did him credit, there was no one in the colony so well qualified to perform a mission of danger, delicacy, and hardship. Washington's antecedents and career are so generally familiar, one hesitates to linger over them. But as they will certainly not be fresh in the mind of many readers, it may be well to recall the fact that he was the great-grandson of the son of a Northamptonshire squire ${ }^{1}$ who had settled in Virginia in the preceding century. George was the eldest of several brothers by his father's second wife, but had no patrimony worth mentioning. The eldest of his half-brothers, however, Laurence Washington, who had a considerable estate, practically adopted him. Laurence had commanded some Virginia volunteers in the disastrous campaign against Carthagena, and had afterwards married into the Fairfax family, who had large interests in the colony, and finally settled down on his property on the Potomac, calling it Mount Vernon after the "hero of Portobello." His wife soon died,

1 Of Sulgrave and Brington. John Washington was the first emigrant, and soon took a prominent part in.Virginian affairs. 


\section{GEORGE WASHINGTON}

leaving only a daughter, and he himself, having contracted the seeds of disease in the deadly South American campaign, succumbed in 1752, leaving George guardian to the child and heir to the estate in the event of her death, which happened no long time afterwards. The great Virginian's boyhood, till he began soldiering, had been largely spent in surveying the vast tracts on the eastern slopes of the Alleghanies, which belonged to the Fairfax family -a life which threw him among Indians, rough backwoodsmen, and all the perils of border life at an age when his contemporaries were leading the semiEnglish life which distinguished the eastern counties of Virginia, or were at school in England, at Eton or Westminster. He constantly enjoyed, however, and greatly to his profit, the society of the old Lord Fairfax, scholar, courtier, soldier, who for a strange whim had secluded himself at his lodge of Greenaway Court amid the noble forests which then covered the Shenandoah Valley. Washington was at this time a tall, stalwart, long-limbed, long-headed, courageous, self-contained youth, who was equally at home in the woods or in the drawing-room, and had even seen something of the outer world, having travelled in the West Indies with his invalid brother. He took keenly to soldiering from the first, and was well equipped by habit and experience for both frontier warfare and frontier diplomacy. A European Dutch soldier, named Van Braam, who had lived at Mount Vernon as half friend, half fencing master, and could speak French, was associated with Washington in this enterprise. So also was Gist, the most famous of frontiermen, together with four or five other white men, and as 
many Indians. Their mission was to march through the woods from the Potomac River to the new French fort of Le Bøuf, only twenty miles south of Lake Erie, no mean performance in the year 1753 ! The chill rains of late autumn fell ceaselessly upon the small party as they pushed their way through the dripping forests, and it was December before they reached the nearer station of the French at Venango. Here an officer named Joncaire commanded, having seized an English trading-house and hoisted above it the French flag. Washington kept a journal of the whole expedition, and tells us how he dined here with the French officers, who, when flushed with wine, declared that, though the English were in a great majority, their movements were too slow, and for their own part they intended to take the Ohio Valley and "by G-d to keep it." They did their best to entice away Washington's Indians, but with great difficulty he managed to get off with his party intact, and in a short time arrived at Fort le Bœuf, the end of his journey, where Le Gardeur de St. Pierre commanded. To him he delivered Dinwiddie's despatch, expressing much surprise that the French should have built forts on what was notoriously British territory, and demanding by whose authority it was done. The note went on to express a hope that the French officer would retire immediately, and so maintain the harmony now existing between the two nations.

St. Pierre was extremely polite to Washington, but wrote firmly, though civilly, to Dinwiddie that he should certainly stay where he was till ordered by his superior officer to retire. The same attempt to alienate the Indian escort was made here as at Ven- 
ango, but without avail. The return journey, as told in Washington's simple matter-of-fact journal, is in itself quite a thrilling story of adventure. In order to save time he left Van Braam with the horses and servants to come on at leisure, and wrapping himself in an Indian match coat, with a pack on his back, rifle in hand, and Gist as his sole companion, the young Virginian, bearing the first formal note of defiance from France to England, prepared to face the perils of the return journey. It was now January, the dead of winter, and some four hundred miles of a pathless and mostly rugged wilderness, riven with torrents and densely clad with forests, had to be traversed. The season alternated between fierce frosts and dripping thaws. The Indians might be encountered at any moment, and their temper in these regions had by French intrigue become most uncertain. One of them, as a matter of fact, actually did hide in a thicket not fifteen paces from the trail, and fired point-blank at Washington, but happily without effect. They caught the culprit, tied his arms and marched him before them for a whole day, lest he should bring his friends in force upon their track. Expecting to cross the Alleghany River on a frozen surface, they found it full of loose blocks of floating ice. Making a raft with their " one poor hatchet," they then embarked in the gloom of a winter's evening on the formidable passage. In midchannel Washington was knocked off the raft by a block of ice into the freezing flood, and the two men had eventually to spend the night upon an island, their clothing frozen stiff upon them. Gist had all his fingers and some of his toes frost-bitten. Pushing on, however, through grey forests, on whose leafless 


\section{3] WASHINGTON'S ADVENTURES}

boughs the drip of the day became icicles by night, and encountering now a straggling band of Indians, now a horrid spectacle of scalped corpses, half worried by wolves or hogs, they arrived on the borders of inhabited Virginia. Here Washington procured fresh horses and fresh clothes, and rode on with his letter to Dinwiddie at Williamsburg, having been absent just three months.

The latter had ere this received permission from the English Government to oppose force by force, and to erect, on his part, forts upon the Ohio, at the expense of the colonial Governments. The officials of both nations were now committed to an armed occupation of the same country-a proceeding which could have but one result. But the French were ready with men and money, and strong in a united purpose. Dinwiddie, on the other hand, could do nothing with the colonial legislatures. His own were squabbling with him about the precise amount of a royalty on land patents, in a territory that was in the act of slipping from their grasp, and made a concession on this point, which the Governor could not legally grant, the condition of defending their own interests against the common foe. The Germans of Pennsylvania would not stir. To these people in their ignorance one Government, so long as it was not the European tyranny they had escaped from, would do as well as another. The Quakers were against all war on principle, and had found their scruples profitable, since the colonies around them, while protecting themselves, virtually protected Pennsylvania. Maryland, which had no such excuses, was almost equally backward, one of the reasons being, according to their Governor, Sharpe, that no men of 


\section{DINWIDDIE AND THE COLONIES [1754}

means, position, and intelligence would belong to the legislature, which was certainly not the case in Virginia. Dinwiddie now begged New York and Massachusetts to make a feint against the French on their borders, and distract their attention from the Ohio. Two independent companies from New York and South Carolina, maintained by the Crown, were placed under Dinwiddie's orders, and his own legislature at last voted $£ 10,000$ for the defence of their own frontier. Virginia, too, possessed a regiment of some 300 men, mostly raw recruits, of which a Colonel Fry, an Oxford M.A., was in command, with Washington as its major. With this formidable host the excellent Dinwiddie prepared to dispute with France, as best he could, the Empire of the West.

It was now the early spring of 1754 . Forty backwoodsmen under an Ensign Ward were sent across the Alleghanies to erect a fort at a place previously selected by Washington, where the two large streams of the Alleghany and Monongahela meet to form the Ohio-a spot to become famous enough in the succeeding years, and in another sense still more famous now. ${ }^{1}$ But armed Frenchmen, soldiers and Canadian voyageurs, had been steadily pouring into the Alleghany back country during the past few months; and Le Contrecour, at the head of $500 \mathrm{men}$, very soon tumbled Ward and his rustic engineers back into the English settlements.

Dinwiddie still for the moment the only active champion of British interests, and being now in funds, mustered his raw Virginian regiment and sent

1 Pittsburg may be called "the Birmingham of America." 


\section{4] WASHINGTON MARCHES}

them forward to Wills Creek on the Potomac, where an English trading station marked the limit at which the feeble outposts of settlement gave way to the gloom of unbroken forests. The weak companies from South Carolina and New York were to follow with such speed as they could make.

Fry remained at Wills Creek with half the Virginians, while Washington with the remainder struck out into the wilderness, the ultimate object of the British attack being the fort which the French were said to be building at the beforementioned forks of the Ohio, and had already named after their Governor, Duquesne. Washington and his 150 men slowly pushed their way north-westward, cutting roads over the lofty forest-clad ridges of the Alleghanies for their guns and pack-trains. They had covered sixty miles, nearly half the march, and had arrived at an oasis in the mountain wilderness, where stood a trading station, known as "The Great Meadows," when word was brought that a French detachment was advancing from the new fort $\mathrm{Du}$ quesne to clear the English out of the country. Taking forty of his men with him, Washington groped his way through the whole of a pitch-dark and soaking night to the quarters of the "Half King," a friendly Indian chief, who had formed one of his party in the diplomatic mission of the previous year. The Indian had some news to give of an advanced scouting party of the French, supposed to be lurking in the neighbourhood, and with some of his people joined Washington at daylight in an attempt to track them. In this they succeeded, and surprised the French lying in a ravine, who, on being discovered, all sprang to their feet, rifle in hand. Washington 


\section{THE FIRST SKIRMISH}

promptly gave the order to fire. A volley was given and returned. Coulon de Jumonville, the ensign who commanded the French, was shot dead, and a few of his men killed and wounded, while the remaining twenty-one were taken prisoners. The killing of Jumonville raised a great commotion, not only in the colonies, but in Europe. "It was the volley fired by a young Virginian in the backwoods of America," says Horace Walpole, "that set the world on fire." It was pretended by the French that Jumonville was on a quasi-diplomatic errand, and the bearer of a letter merely ordering the English to retire. It was quite true he had on his person a letter authorizing him to expel any English he found in his path, but an unfounded report was circulated by the French that he jumped up and waved this letter towards Washington as a sign of peaceful intentions, and that, in fact, he was treacherously shot. An effort was made, in short, to brand Washington as an assassin, and not without success among the French. If the incident had occurred to-day, there is no manner of doubt but that not a few Englishmen too would have jumped to that conclusion with ready instinct, and stuck to it, for the simple reason that Washington was a Briton and Jumonville was not. It is equally certain that the policy which eventually made North America Anglo-Saxon, free and prosperous, would have been as loudly opposed by the same type of patriot, on the principle that, as neither nation's claim was worth anything, that of the foreigner was most worthy of support. Apathy, it is true, very nearly accomplished what the perverted sentimentalism of some and the less creditable motives of others would now demand under similar 


\section{4] THE JUMONVILLE AFFAIR}

conditions; but apathy is, after all, quite another matter, though at this crisis of the nation, or to be more accurate, of the Anglo-Saxon race, it eame very near to signifying incalculable disaster.

Jumonville and his men, it transpired, had been lying concealed for two days in the neighbourhood of Washington's superior force-scarcely the natural method of procedure for a peaceful convoy! De Contrecour, commanding the main force of some 500 men, was advancing in the rear, and his scouting subaltern, who, as a matter of fact, had sent messengers to hurry him up, was simply waiting for his arrival to overwhelm the small British detachment.

Washington after this retired to the Great Meadows, where his second battalion, though without their colonel, who had died, now arrived, together with the South Carolina company, consisting of fifty socalled regulars, raised in the colony but paid by the Crown. The young Virginian was now in command of 350 men, but the Carolina captain, being in some sort a king's officer, refused to take orders from him as a provincial, admirably illustrating one of the many difficulties which then hampered military action in the colonies. His men assumed similar airs, and would lend no hand in road-making, carrying packs, or hauling guns. So Washington laboured on with his Virginians, seeking for some good defensive point at which to receive the attack of the large force he heard was advancing against him. After much labour it was decided to return again to the Great Meadows, and there entrench themselves as best they could. It was not a good situation, but Virginians and Carolinians, reconciled by their common danger, now united in throwing up a rough 


\section{WASHINGTON PREPARES TO FIGHT [1754}

entrenchment surrounded by log breastworks and a dry ditch.

It was now the middle of June. De Jumonville's brother, Coulon de Villiers, on hearing of his death in Canada, had hurried southward with a strong band of Indians, burning for revenge. There were already 1,400 men at Fort Duquesne, seventy miles from the Great Meadows, and De Villiers arrived just in time to take part in the fresh expedition setting out against Washington. It was intended that if the British could not be caught in the disputed territory, they were to be followed into Pennsylvania and there attacked. But Washington had no intention of retreating, or, to be more precise, his men and horses were in such a weak condition that he was unable to.

So he drew up his force outside the poor entrenchments, which he had aptly called Fort Necessity, and seems to have had some vague idea of encountering the French in the open. But when at eleven o'clock some eight or nine hundred of the enemy, including Indians, emerged from the woods, it soon became evident that, with such excellent cover as nature afforded in the overhanging hills, they were not going to take the superfluous risks of a frontal attack.

The British thereupon withdrew inside their works, and the French riflemen scattered among the wooded ridges that so fatally commanded them. A musketry duel then commenced and continued for nine hours, while a heavy rain fell incessantly. Washington's guns were almost useless, for they were so exposed that the loss of life in serving them was far greater than any damage they could inflict on the enemy. 


\section{4] BATTLE OF “GREAT MEADOWS"}

The men were up to their knees in water and mud; their bread had been long exhausted, and they were reduced to a meat diet, and a very poor one at that. This ragged regiment, in home-spun and hunting. shirts, half - starved, soaked to the skin, and with ammunition failing, not from expenditure only, but from wet, fought stubbornly throughout the day. From time to time the very force of the rain caused a lull in the combat, the opposing forces being hidden from one another by sheets of falling water.

The French, as the day waned, proposed a capitulation, which Washington refused. But his ammunition at length gave out entirely, and as the gloomy light of the June evening began to fade, a fresh proposal to send an envoy to discuss terms was accepted. The indispensable Van Braam, as the only one of the British force who could speak French, was sent to negotiate. Nearly a hundred men of the defending force lay killed or wounded, while the French loss, though not so great, turned out to be considerable. The terms offered, after a little discussion, were at length accepted, and were honourable enough; namely, that the garrison were to march out with the honours of war, earrying their effects and one gun with them. The French were indeed in no position to take or maintain prisoners. Moreover, the fiction of peace between the two nations had to be taken into some sort of account.

Now in the articles of capitulation the phrase "l'assassinat de Jumonville" appeared. Van Braam read a translation of them aloud to Washington and his officers, and either from an imperfect knowledge of the language, or quite possibly from 


\section{WASHINGTON SURRENDERS [1754}

a desire to cause no hitch in the extremely uncomfortable situation, rendered the obnoxious phrase in a different fashion, translating it "the killing or death of Jumonville."

The articles were read in English and signed in the darkness and rain by the light of a sputtering tallow dip, and Washington's signature innocently affixed to the statement that he was practically a murderer. One can well believe that this apparent confession was a cause of much joy and triumph to the French, both among those who knew the real facts and those who did not. One does not hear of any Englishmen who rejoiced at this documentary evidence. Washington and his soldiers indignantly denied the monstrous story that Jumonville was a peaceful envoy, and were sufficiently exasperated at the trick played in the translation. ${ }^{1}$ Their word was good enough in those days for their countrymen, both in England and America.

The French prisoners who had been taken in the Jumonville affair were to be sent back, while, as hostages for the undertaking, the inaccurate Van Braam and a Scotchman named Robert Stobo, who will turn up again in another place at a much later period in this story, were retained by the French.

The fifty-mile march return over the mountains to Wills Creek was a pitiful business. The wounded had

1 The articles were written in a bad hand, and smudged with rain. The candle, says an officer present, could scarcely be kept alight for Van Braam to read them out by. No hint of the objectionable word was given; while both sides, from the misery and discomfort of the situation, were in a hurry to terminate the formalities. 


\section{4] THE HOMEWARD MARCH}

to be carried on the backs of their weakened, travelworn comrades, for the Indians, threatening and noisy, were with difficulty prevented from a general onslaught, and, as it was, killed all the horses and destroyed the medicine chests. It was a sorry band that struggled back with Washington across the Alleghanies, by the rough track that a year hence was to be beaten wider by the tramp of British infantry marching to a fate far more calamitous. They were for the most part poor men, the waifs and strays of Southern life, fighting and toiling and starving for eightpence a day. Both they and their young leader, now full enough, we may be sure, of gloomy thoughts, had done their duty, to the best of their knowledge and experience, against trained soldiers, and most certainly with valour. If they had left the French triumphant in the West, and the prestige of Britain in a woeful plight, it was at least no fault of theirs.

On arriving at Wills Creek they heard that the North Carolina regiment who had been ordered to support them had mutinied on the way, while the New York contingent were still labouring southwards with a tribe of women and children and no equipment for a campaign !

The fight at the Great Meadows was in itself a small affair, but its effect was prodigious. Judged by modern ethics, it seems incredible that formal peace between France and England should remain undisturbed by such proceedings; but we shall see that the peace outlasted events far more critical, owing to the desire of France to get more forward in her preparations before the coming struggle actually opened, and to the apathy reign- 


\section{EFFECTS OF BRITISH REVERSE [1754}

ing in the councils of England. But, peace or war, the great conflict had begun, and the incapacity of the colonies to help themselves had been so fully demonstrated as to turn men's minds across the sea, as to the only quarter from which efficient help could be expected. 


\section{CHAPTER III}

DINWIDDIE was full of wrath when Washington 1 reached Williamsburg with the news of his discomfiture and the state of affairs beyond the mountains. His zeal, useful as it was, greatly exceeded his military discretion, though this is not to imply for a moment that he was out of temper with Washington. Indeed, he warmly thanked both him and his men, as did also the Virginia legislature, and well they may have, seeing how bravely they had conducted themselves under dangers that no military commander would have sent so weak a force to face. Dinwiddie's ire was expended rather on the dilatoriness with which the other colonies had supported his efforts, for to this he attributed the discomfiture of his little army. The affair of the Great Meadows, we may well believe, was now the talk of the back country from New Orleans to Lake Erie and the joy of Canada. No English trader dare any longer cross the mountains. British prestige had vanished in the West, and the French were everywhere paramount; yet the colonists were still quarrelling briskly, both with one another and with their governors, concerning land grants and patents situated in this very country.

The Virginia legislature, as I have said, passed a 


\section{ENGLAND PROTESTS}

vote of thanks to Washington and his men, and expressed proper regret at their misfortunes. Importuned by Dinwiddie, they voted $£ 20,000$ for military purposes, but again saddled with some irrelevant condition that the Governor was by his instructions not free to sign. Soon afterwards, however, they voted the money without the obnoxious rider. "Thank God," wrote the distraught official in the middle of this contest, "I have never before had to do with such obstinate and self-conceited people. A governor is truly an object of pity."

The British ambassador at Paris in the meantime had made urgent representations to the Government of Versailles regarding what his nation considered to be the unjustifiable occupation of the Ohio Valley, but to no purpose.

In the preceding year the lords of the Board of trade and plantations had ordered the various Governors of colonies to make some efforts at combination, and the result had been a conference at Albany, where representatives from seven provinces met, both to discuss this question and to confer with the chiefs of the Six Nations who had ready access to the New York frontier town. Benjamin Franklin, from Pennsylvania, already held to be one of the most capable men in the country, had elaborated a scheme of colonial combination that was pronounced to be excellently conceived, and went a considerable way towards the results that in later days were so painfully but successfully achieved without the help of England. Neither party, however, were prepared to accept it. The mother country thought it gave the colonists too much power, while the latter, on the other hand, jealous to a fault of their inde- 


\section{4] THE SIX NATION INDIANS}

pendence, thought Franklin's scheme encroached on what they already possessed. The commissioners were the best men of their respective colonies, and approved of the plan; but they had no authority to act, and their constituents were not in accord with them.

The desperate endeavours of the French to undermine the attachment of the Six Nations towards the English, and procure their support, had not been without effect, and they had been materially assisted by the bad conduct of the Dutch traders from the Hudson, and even of the New York Commissioners. Detachments of these hitherto staunch tribes had been already enticed away, some into Canada, others southward into the Ohio Valley. The revolt of the Iroquois (to use a convenient term), whom the treaty of Aix-la-Chapelle had actually recognised as English subjects, would have been disastrous. Of infinite service, however, at this crisis was a young Irishman of good birth, named Johnson, who had settled in the back country on the Mohawk River, and acquired an immense influence over these particular nations. He was now, of course, at Albany in person, and the Indian chiefs did not mince their words. They accused the English of deserting them, while the French were continually soliciting their friendship; of failing to build forts, while their enemies were swarming into the country; of already discussing the partition of their lands and of quarrelling at that very moment with the French about territory that belonged to neither; while for the Dutch traders from Albany they had not a good word to say. The Six Nations were, in fact, on the very verge of repudiating the 


\section{THE GERMAN COLONISTS}

old alliance. Johnson, however, was the man of the hour, who stepped into the breach-one of those many Britons whose sway over native races has been of more profit to his country than rifles and regiments, and we shall hear of him again.

The Dutch and English, as I have before noted, were for all practical purposes one people; but the Germans of Pennsylvania and the Jerseys were, in Franklin's opinion, a wholly undesirable element, and even a dangerous one in times like these. $\mathrm{He}$ admits that they were plodding, industrious, and peaceable; but their rapid increase and rejection of the language of their adopted country made him fear that the province of Pennsylvania might in time become wholly German, and the English tongue actually die out. In the legislature and the law courts their language, he says, was becoming an intolerable nuisance, and their stupidity, he declares, alarmed him. People were even beginning to consider whether it was advisable to admit them at all as immigrants. They not only refused to arm in defence of the province, but mocked openly at those who did, and were in the habit of remarking that they would as soon be under French as English rule. ${ }^{1}$

A little of the most Catholic king, of his archbishops, and his thieving officials and iron-fisted generals would very soon have satisfied these poor ignorant Lutherans. Yet in spite of Franklin's contempt for their persons and his dread of their numbers, it may not be amiss to remember that

1 The familiar American colloquialisms "Yankee Dutchman," "Pennsylvania Dutch," have no allusion to the Dutch proper of New York, but apply wholly to the German-American stock of Pennsylvania and the neighbouring States. 


\section{5] BRITISH TROOPS DESPATCHED}

either want or the attraction of pay made soldiers: eventually of many of them, for our present 60 th Rifles, as will soon appear, chiefly consisted in its inception of German-Americans. But the result of all this chaos, this jealousy between colonies, this general inability to divine the future, and helplessness in face of a determined and united foe, was an urgent demand on the home Government to send out troops and a competent general.

Parliament met in November, 1754, and money was then voted for the despatch of troops to His Majesty's American plantations-only, be it noted, for their protection,-no declaration of war being so much as hinted at. So before January was out, the 44th and 48th regiments of the line had sailed from Cork Harbour, and a fleet of transports was labouring heavily westwards through the wintry seas.

England at this moment was neither happy in her rulers nor well equipped for war. Her navy, it is true, was considerable; but her army had been reduced to twenty thousand men-about the number, in fact, that the small provinces of New England four years later placed in the field. Her generals were of very moderate capacity, though among the younger officers there was some rising talent, which jobbery and corruption could not wholly strangle. Affairs of state, too, were just now in lamentable hands. The ridiculous Newcastle, to whom politics in its petty sense was a passion and who had no conception of anything loftier than distributing patronage with the sole object of retaining office, was Prime Minister. Sir Thomas Robinson had charge of the colonies, in connection with whom it has been said that New- 


\section{FRANCE REPLIES}

castle's crowning feat was in finding a coadjutor who was a greater fool than himself. If there had been reasonable prospects of a lasting peace, the British ambassador at Paris, Lord Albemarle, was not calculated to improve them. His success as an absorber of lucrative positions without capacity for any of them is the text of a somewhat memorable paragraph on the value of good manners in one of Lord Chesterfield's letters to his son. He points out the moral of "a mere Dutch gentleman, without estate, learning, parts, political abilities or application," achieving such a position by "his air, his address, his manners, and his graces." $\mathrm{He}$ was infatuated with a French mistress, who not only ruined him but sold his secrets to the Government. Albemarle died just before the English expedition sailed, and it was then too late for diplomacy to do anything but stave off the inevitable conflict. But this France alone was interested in doing till her preparations were complete. Great Britain, though her statesmen talked peace, made no further pretensions to act it.

It must not be supposed, however, that the despatch of the British force had been unobserved by France. On the contrary, it was regarded in some sort as a challenge, and 3,000 soldiers, with a new Governor of Canada, the Marquis de Vaudreuil, sailed, after much delay and under a strong naval escort, from Brest, early in May. Yet in the face of these unmistakable demonstrations, the two Governments assured each other of their sentiments of mutual friendship and esteem, advancing at the same time their respective claims in America, which were hopelessly irreconcilable. If the secret in- 
structions deposited with each commander had at that moment been published to the world, they would have caused no little astonishment. Boscawen and Holborne, with some eighteen ships of the line between them, were in the meantime despatched in two parties to cut off the French, an attempt which met with very little success. Off the coast of Nova Scotia, however, two advanced British ships came up with an equal number of French stragglers, the Alcide and the Lys. Hocquart, the commander of the Alcide, shouted through a speaking trumpet to Howe (afterwards Lord Howe), of the Dunkirk, whether it was peace or war. A French account runs that Howe called out "La Paix, La Paix," and after inquiring the French captain's name poured a broadside into him. Howe's story is that he replied he did not know till he had signalled to Boscawen, but he advised Hocquart to be prepared for war. Then came the signal to fight, and the action opened which ended with the capture of the two French ships, carrying eight companies of soldiers, and the loss of eighty-six men on the French side and thirtyfour on the British. The rest of the French fleet were safe in Louisbourg Harbour. The news of this fresh collision caused some excitement in Europe. The Versailles Government recalled its ambassador, but still shrank from declaring war. All this took place in the month of June, during which events of still more serious moment were hastening to a crisis in the forests of the Alleghanies.

On the 20th of February the small British armament cast anchor in Hampton Roads, Virginia, when General Braddock, who was in command, proceeded at once to Williamsburg, the capital of the colony, to 
confer with its eager and expectant Governor, Dinwiddie. The fleet then sailed up the Potomac and deposited the troops where the Virginia town of Alexandria, then in its infancy, now looks across the broad river towards the noble buildings of the city of Washington. These two regiments were the first substantial force of British regulars that had ever landed on American soil, unless, indeed, we go back to that curious revolt against Governor Berkeley in 1676 and the brief civil war in Virginia, which was finally extinguished by the landing of a mixed battalion of Guards.

Concerning Braddock, seeing that his name has been immortalized by the tragedy for which some hold him, in part, accountable, a word or two must be said. He was now over sixty years of age, and was the choice of the Duke of Cumberland, then commander-in-chief. As he had neither wealth nor influence, American warfare not being in request by fortune's favourites, we may fairly suppose that he was selected on his merits. No name has been more irresponsibly played upon and few reputations perhaps more hardly used than Braddock's by most writers of history and nearly all writers of fiction. His personality, from its very contrast to the wild woods in which he died, has caught the fancy of innumerable pens, and justice has been sadly sacrificed to picturesque effect. One is almost inclined to think that the mere fact of his name beginning with a letter which encourages a multiplication of strenuous epithets, has been against him. He is regarded as the typical redcoat of the Hanoverian period by all American writers-burly, brutal, blundering, blasphemous, but happily always, and without a dissen- 


\section{5] BRADDOCK'S CHARACTER}

tient note, brave-brave indeed as a lion. This familiar picture of our poor general, as a corpulent, red-faced, blaspheming bulldog, riding roughshod over colonial susceptibilities, tones down amazingly when one comes to hard facts. Legends of his former life are, with peculiar lack of generosity, quoted for what they are worth, and when examined they seem to be worth nothing. Walpole airs his wit in one or two doubtful aspersions, and a play of Fielding's is with little reason supposed to satirize the general's earlier years. What is really known about Braddock is in his favour. Vanquished in a duel, he had been too proud to ask his life. In command at Gibraltar he was "adored by his men," and this though he was notorious as a strict disciplinarian, a quality which Wolfe at this very time declares to be the most badly needed one in the British army. He had been in the Guards, had enjoyed a private income of some $£ 300$ a year, which it may be noted, since spendthrift is one of the epithets hurled at him, he slightly increased during his lifetime. The night before Braddock sailed, he went with his two aides, Burton and Orme, to see Mrs. Bellamy, and left her his will, drawn up in favour of her husband. He also produced a map, and remarked, with a touch of melancholy, that he was "going forth to conquer whole worlds with a handful of men, and to do so must cut his way through unknown woods." $\mathrm{He}$ was, in fact, the first British general to conduct a considerable campaign in a remote wilderness. He had neither precedents nor the experience of others to guide him, and he found little help in the colonies where he had been taught to look for much. He has been accused of dis- 


\section{BRADDOCK AND THE COLONISTS [1755}

paraging the colonial irregulars and neglecting to utilize the Indians. As to the first taunt, having regard to the appearance and discipline of the provincial troops that were paraded before Braddock, he would not, as a soldier trained on European fields, have been human had he not refrained from all open criticism; as to the second, we shall see that it was untrue. Information regarding colonial resources was then vague in England. Braddock had been given to understand that the transport and commissariat would be provided by Virginia and her neighbours; whereas he now found that not only was nothing ready, but that there was no ground even for future expectations in that particular. If, as an officer of the Cumberland régime, he had used the vigorous language of that school, it would surely have been almost justified by circumstances; but there is no particular evidence that he did even so much. His accomplishments in this line are in all probability part of the more or less fancy dress in which writers have delighted to clothe him. Robert Orme of the 35 th regiment, and recently of the Coldstreams, was one of the general's aide-de-camps, and has left us an invaluable journal of this expedition. Orme was highly thought of both by regulars and provincials, and regarded as a man of great sense and judgment, even by those who did not like Braddock and thought him, from their colonial point of view, unconciliatory and overbearing. Orme in his private diary gives no hint that Braddock was the violent, unreasonable, foul-mouthed person of the magazine writer. He was as much disheartened as his chief by the appearance and seeming temper of the colonial troops, and dwells on the trying conditions 
which Braddock had to meet and the energy and honesty with which he endeavoured to do his duty.

The two British regiments in the meantime were being raised from 500 men to a strength of 700 by provincial enlistment. The 44th was commanded by Sir Peter Halkett, a good officer, who, ten years previously, had been captured by the Pretender and released on parole. The 48th were under Dunbar, who acquitted himself but poorly as we shall see. The camp of exercise on the Potomac was a strange and inspiring sight to the colonists, who had now begun in some sort to realize the French danger. With all their seeming apathy, the Virginians and Marylanders were staunchly loyal. The echoes from far-off European fields, won or fiercely disputed by the intrepidity of British soldiers, were still ringing in their ears. Stories of Dettingen and Fontenoy were yet told by cabin fires and on the planters' shady porches by new-comers from England and sometimes, no doubt, by men who had assisted in those glorious victories and scarcely less glorious defeats. Here now were these redoubtable redcoats, gay in all the glitter and panoply of war, actually marching and manœuvring on the warm soil of the Old Dominion. If there had been anything in this French scare, there was now at any rate no further cause for alarm. It was a great opportunity, too, for the gentry of the Potomac shore to indulge at the same time their loyal and their social instincts. Tradition says that the ladies appreciated the situation more than the gentlemen of the colony, who were not over-pleased at the supercilious bearing of the British officers. Washington, whose estate at Mount Vernon lay within a few miles of the Alexan- 


\section{A COUNCIL OF WAR}

dria camp, was a frequent visitor. A stickler always for punctilio and with a keen sense of justice, he had resented an order which placed all king's officers over all provincial officers, irrespective of rank or experience, and before Braddock's landing had resigned his commission. Such a keen soldier as he, was sorely tantalized, we may be sure, by all this pomp of war. Nobody ever seems to have thought of snubbing Washington, and to save him the indignity he would not stomach, namely, that of ranking, colonel as he was, under a British ensign, Braddock with kindly forethought placed him on his personal staff. Curiously enough, there seems to have been no general misgiving as to the ability of these well-drilled redcoats to meet the French and Indians in the heart of the forests. On the contrary, save for an occasional note of doubt, the middle colonies only saw in these invincible warriors an instrument which was to sweep the French for ever from their path and from their minds.

A council of colonial governors and British officers was held at Alexandria on April 14th, when a definite plan for the season's operations was drawn up. The chief expedition, of course, was that of Braddock and his regulars against Fort Duquesne, already decided upon. But it was thought advisable to distract the French at other points with such forces as the British Americans had at their disposal. Shirley, the clever and capable Governor of Massachusetts, though of middle age and no soldier, had some passion for military glory, and was immensely gratified at being placed in command of a force destined for the capture of Niagara. Acadia, now in the throes of those troubles alluded to in a former chapter, was to 


\section{5] STRENGTH OF THE ENEMY}

be the scene of a vigorous movement by Monckton against the troublesome French fort of Beausejour on the boundary. Johnson, the backwoods statesman and soldier, was to strike at the chain of lakes which led due north from Albany to Canada and formed that famous and bloodstained highway between the two countries which will be the scene of many later chapters in this book. For the present it will be enough to say that these blows were to be struck almost entirely by the better organized provincial militia of the Northern colonies. The limited nature of their success will be briefly alluded to hereafter, and the remainder of this chapter will be devoted to that tragic and memorable disaster known as "Braddock's defeat."

In Canada there were now available, or soon would be, 3,000 troops of the line, in addition to the 2,000 marine or colony regulars and the colonial militia, estimated at about 15,000. Nor does this include the Louisbourg garrison, numbering 1,400 regulars. What fraction of this force had moved southwards through the vast wilderness to Fort Duquesne no one for a certainty then knew. It was the key to the Ohio Valley, and, indeed, to the whole situation, and strenuous efforts would be made to hold it. There were not believed to be as yet more than 500 white troops on the spot, but the number of Indians was an entirely unknown quantity, and they were quite as formidable so long as they remained in real earnest on the war-path.

As regards Indian help for Braddock, Dinwiddie had undertaken that 120 warriors should be at his service. It was not his fault that less than half that number, and those anything but zealous, came 


\section{DIFFICULTIES OF TRANSPORT}

straggling in. They were so hampered, moreover, with women and children that the provincial officers assured Braddock that the tax on the commissariat would be greater than the assistance of so small a number was worth. The general has been roundly accused of despising Indian help, whereas he never had a chance to reject it in any substantial form, though he made all the advances which his somewhat helpless position admitted of ; indeed, he made their backwardness one of his chief complaints. As it was, less than a dozen went through to the end with him as scouts. Braddock had now been two months in Virginia, and in spite of indefatigable exertions found himself thwarted and balked at every turn. If he showed some temper and used strong language, he may well be excused, for though 1,500 horses and 125 wagons were needed, and had been promised, by the end of April, 25 wagons only had been secured, and those mostly by his own exertions! There were, in fact, no wagons to speak of in all Virginia. They were not then necessary to its single industry, as any one familiar with that country and its peculiar conditions can readily understand.

Benjamin Franklin, then postmaster at Philadelphia, was at the general's right hand, dining daily at his table- " the first capable and sensible man I have met in the country," wrote poor Braddock to his Government. ${ }^{1}$ Franklin undertook the wagon business, and with great effect he turned to Pennsylvania, a colony of prosperous small farmers, apathetic as to the war, but possessed of abundant

${ }^{1}$ Franklin, it must be admitted, did not return Braddock's regard. 


\section{5] MUSTER AT FORT CUMBERLAND}

agricultural requisites. Franklin appealed not to their patriotism but to their pockets, or rather to their fears, telling them roundly that it would be better to hire their wagons and teams to His Majesty's Government than wait till they were dragooned, as with a fine touch of ready audacity he assured them they certainly would be. He, moreover, pledged his personal eredit, and both the required wagons and several hundred horses were collected in a few days. With the food contractors in Virginia, too, there was infinite difficulty: the meat was rancid, the flour was short, while many of the horses were afterwards stolen by the very men who had sold them. Whatever were Braddock's faults, and one of them no doubt was cursing both the country and the Government which sent him there, he at least spared neither himself nor his private purse, which last he drew upon freely, Orme tells us, in his struggle for ways and means.

Wills Creek or Fort Cumberland, a former trading station some hundred miles westward up the Potomac, was to be the actual base of the expedition against Fort Duquesne. It was behind the settlements, and stood amid a stump-strewn clearing in the forests on the Maryland shore of the river. By the middle of May, and by various routes, Braddock's whole force had gathered at this backwoods station, which was bounded on one side by the river and on the other three by the leafy walls of the primæval forest. Braddock himself had crossed the Blue Ridge into the valley of the Shenandoah, and paid a visit en route to the eccentric Lord Fairfax, near the backwoods village of Winchester, where Washington joined his staff. Thence, moving north- 


\section{BRADDOCK'S ARMY ADVANCES [1755}

ward, he crossed the Potomac, resumed command of his army at Fort Cumberland, and after a few more struggles with belated contractors of food, forage, or horses, by the 7th of June was in a condition to commence his march with safety.

The small force was divided into two brigades. The first was under Sir Peter Halkett, and contained the 44th regiment, now numbering 700 effective men, with 230 New York, Virginia, and Maryland rangers and 50 carpenters. The second brigade, under Dunbar, included the 48 th regiment, 650 strong, 170 rangers from the Carolinas, somewhat less from Virginia, and 35 carpenters, in all nearly 2,000 men. It was absolutely necessary to take supplies for not less than nine weeks, since 122 miles of rugged and heavily wooded mountain country had to be traversed, where no subsistence worth mentioning for either man or beast was to be found, to say nothing of the provisions for the troops to be left as garrison of the backwoods fortress which they hoped to capture. The 44th, under Halkett, were the first to enter the forest; next came the provincials, under Burton, while Dunbar and the 48th, with the general and his staff, brought up the rear. Washington, who from illness and other private reasons had been as yet little with Braddock, ventured to contest the sweeping verdict of the harassed general, namely, that the population of these colonies consisted chiefly of knaves or fools. But Washington had not shared his commander's troubles, though he had plenty of his own of a like nature a few months later, and has left comments upon them as strong as poor Braddock's. All the sympathy the unfortunate general got from the British 


\section{5] DIFFICULTIES OF THE FOREST}

public was probably expressed with tolerable accuracy by Horace Walpole, who amused his fellow-dandies at St. James' by remarking that Braddock seemed "in no hurry to get scalped."

The route followed to the Great Meadows was much the same as that used by Washington and his small force in the preceding year, but now a road twelve feet wide had to be opened over the rugged, treeencumbered ground. Its course lay neither over veldt, nor plain, nor prairie, nor sandy desert, nor Russian steppe ; but over two high ranges of mountains and several lesser ridges, clad in the gloom of mighty forests, littered with the wreckage of unnumbered years, riven this way and that by turbulent streams, and swarming with hostile Indians. After a day or two's march it was generally recognised, Orme tells us, that the loads must be lightened. This done, and the officers' kits reduced to bare necessities, they even then took a week to reach the Little Meadows, only twenty miles from Fort Cumberland, and the long line, which had to guard against surprise at every point, straggled over four miles. A strange enough sight in those wild woods must have been the long train of jolting wagons, dragged by ill-conditioned horses, growing daily weaker ; the clumsy tumbrils, and artillery, and ammunition carts jolting and crashing over the roughmade track; the strings of heavy-laden pack-horses, stung by deer-flies and goaded by the drivers' whips, sliding and slipping over limestone slabs, and floundering amid stumps and roots; the droves of stunted cattle shambling unwillingly along the unfenced track; the fresh-faced soldiery, in tight scarlet uniforms, pigtails and pipeclay, mitre hats and black- 


\section{BRADDOCK AND WASHINGTON [1755}

gaitered legs, sweltering in the fierce, unwonted heat of an American midsummer sun, whose vertical rays pierce even the rich canopy of leaves that high June spreads aloft, and which rustle so temptingly in breezes unfelt below.

By the 19th of June it was evident to Braddock and his officers, including Washington, that greater expedition must be made. To press on with a small force merely carrying rations was out of the question. Indian runners had stated the French at Duquesne to be as yet comparatively few, but the number of their savage allies was altogether outside calculation. Without artillery, the fort would require a long siege-was, in fact, impregnable; and lastly it was perilous any longer to venture in small numbers into a country towards which the French were hastening in unknown strength. The pace, however, was somewhat mended by leaving $600 \mathrm{men}$, including the sick, and all the weaker horses, to come leisurely on with Dunbar; while Braddock, with 1,200 regulars and 200 of the best provincials, pressed forward at a somewhat less snaillike rate. Washington was so ill with fever that Braddock absolutely compelled him to stay with Dunbar's rear column, promising upon his honour to have him sent forward to the front in time for the fight. "I would not miss it for $£ 500$," wrote the ardent young soldier to his friends in Virginia. So Braddock, making the patient in his turn solemnly promise to take "Dr. James's powders, the best medicine in the world," pressed on with his reduced column. They had still 92 miles between them and Fort Duquesne, but now managed to achieve between five and six miles a day. Sometimes their 


\section{5] IN THE SHADOW OF THE WOODS}

slow progress lay through open forests, where the giant stems of oak and poplar, chestnut and maple, rose from a clean carpet of fallen leaves, or spread their leafy roof over wide-stretching and luxuriant masses of rhododendrons and azaleas, just now in the very zenith of their bloom; at other times they were brushing between sombre walls of cypress and hemlock which hid the sunlight and the heat from dank deep soils where the moss-grown carcases of fallen trees lay heaped together in all stages of decay. Now the long column was clinging precariously to a precipitous hillside, beneath which some pent-up torrent churned and roared. Now it was struggling-cattle, horses, wagons, and men-in some rocky channel, where a shrunken stream trickled amid the débris of its winter floods. Signs of French and Indians were plentiful, but as yet they kept their distance, filling the measure of their hostility with taunts and ribald verses smeared upon the trees. Admirable discipline was maintained, and every precaution that prudence required was observed by Braddock. Men were thrown out upon both flanks marching abreast through the trees, while beyond these again scouting parties ranged the woods. A careless straggler was occasionally killed and scalped, but no party of the enemy ventured an attack on the column, attenuated though it of necessity was. Christopher Gist, Washington's former guide, acted again in that capacity, while a handful of Indians and mounted Virginians cautiously probed the forest in advance.

On the 7th of July, after a month's march, the column arrived within a dozen miles of its destination, and its difficulties seemed almost over. 


\section{THE NIGHT BEFORE THE BATTLE [1755}

Whatever reinforcements might have reached Fort Duquesne, the French and their allies could hardly be in great strength, or some sort of demonstration would surely have been made, particularly as the Indians had small liking for open spaces and artillery. "Men and officers," says Orme, "had now become so skilful in the woods that they were no longer in fear of an ambuscade." Nor did Braddock for that matter, as is often loosely stated, eventually run into one. The army was now within a few miles of the Monongahela, which rolled with broad and shallow current on the left and in a north-westerly direction to its junction with the Alleghany. These two rivers unite to form the Ohio, and in the angle of their junction, on a site now buried amid the smoke and din of Pittsburg, then stood the lonely fortress. The shortest route for Braddock was to continue his course parallel with that of the Monongahela, but the broken nature of the country made the risk too great. It was decided, therefore, to ford the river, and recross it at a spot some five miles lower down and eight from the French fortress. On the next day, July the 8th, the column moved down to within a couple of miles of the first ford, and there bivouacked for the night. It was to prove the last sleep from which one half, at any rate, of the poor fellows who there made their beds of leaves and pine brush were ever to awaken. Washington, in accordance with Braddock's promise, was brought up that evening, though still weak with fever, having left Dunbar and his 600 men at a spot called Rock Fort, some fifty miles in the rear. The troops were to cross the river twice in the course of the next day's 94 


\section{5] PASSAGE OF THE MONONGAHELA}

march, and if all was well would camp sufficiently near the fort to strike it on the following morning, for progress had now become much easier. At dawn Sir John Sinclair with the engineers and axemen went forward, as usual, to clear the road. At sunrise Gage, of later and less favourable notoriety in the Revolutionary war, but now a promising young brevet-colonel, with 300 men and two guns, marched out of camp to occupy the second ford, some five miles below the first. It was eight o'clock when the main body waded the Monongahela, and it had scarcely entered the oak forests which clothed the further bank, when a messenger from Gage arrived announcing that he held the further ford. It was past noon when the rest of the column arrived there, and the reunited force was drawn up by Braddock preparatory to making the passage of the river, at this spot about two hundred yards broad, with some pomp and circumstance.

Beyond the river the ground swelled up into low hills, clad with the inevitable forest. No enemy was visible, but from behind that vast screen of foliage many a pair of eager eyes, both French and Indian, were fastened on the broad sheen of sunlit waters which here broke for a space the forest and its illimitable canopy of leaves. Knowing this full well, and regarding with some justice the abandonment of both fords as a confession of weakness, Braddock determined to effect this last passage of the Monongahela in a fashion worthy the soldiers of a proud empire coming to enforce its outraged rights. So the troops were marched across by companies with much precision and with colours flying, while drum and fife and bugle woke the echoes of the woodland wilderness with stirring and familiar strains. 


\section{THE TERRIBLE WAR-WHOOP}

Reforming on the further bank, the column moved forward in much the same order and with apparently no less caution than before. Half a dozen Indians and some Virginia light horsemen felt the country in advance. Then came the road-makers with Gage, his two guns and 300 men, while as many yards behind followed the main column. It was now about eight miles to the fort, and the order was to march till three o'clock, when the last camp would be pitched before what was fondly looked for as the crowning triumph of the morrow.

In this order the troops had proceeded the better part of a mile, and had reached a spot where the underbrush grew thicker than usual beneath the trees. The vanguard under Gage had just crossed a shallow ravine, when the scouts and horsemen came rapidly in, and at the same moment Gordon, the engineer who was marking out the road, caught sight of a man, dressed as an Indian but wearing the gorget of an officer, running towards him. The latter, as soon as he saw the English, pulled up short and waved his hat over his head, when the woods in front became of a sudden alive with warriors, and the Indian war-whoop ringing from nearly a thousand throats shook the arches of the forest with its novel and appalling clamour. Forms innumerable, some in white uniforms, some in blue, still more in the weird feathered head-dress and garish pigments of the Indian, could be seen speeding to right and left among the trees. In a few moments a musketry fire, at first desultory but as each fresh enemy found cover quickening rapidly into a formidable fusillade, poured in upon Gage's men. For a short time many of the foe were 


\section{THE FIRST SHOCK}

visible, and the small British vanguard wheeled into line and delivered two or three volleys with steadiness and precision. But the enemy, with a far greater superiority of aim than the modern Boer has over the modern redcoat, and with a brightcoloured exposed target such as was rarely offered to him in forest warfare, was already playing deadly havoc. The British bullets did little more than sliver the bark from trees and cut the saplings. Gage's two guns, however, were brought into action, and fired three volleys of grape and canister, which seem to have accounted for much of the slight mortality which the enemy experienced on this fatal day. Indeed, if the British, enveloped in that thickening canopy of smoke and leaves and already shaken by such a hail of lead from almost unseen foes, had only known it, the moment was a critical one for the enemy. De Beaujeu, their leader, whose waving hat had been the sign of battle, was lying dead in the bushes. Dumas, who succeeded to the command, has told us how his hundred and fifty Canadians, headed by their two young officers, had fled shamefully at the first discharge of grape, crying "sauve qui peut," how the main body of the British infantry were coming up behind the smoke with loud shouts of "God save the King!" and how the six hundred Indians, flinching as ever from artillery, were leaving their cover and showing signs of abandoning the field to himself and his officers and the seventy French regulars who held their ground. With infinite presence of mind and a gallantry that Dumas himself somewhat modestly attributes to despair, he and his lieutenants, conspicuously assisted by a famous half-breed leader, Langlade, 


\section{BATTLE OF THE MONONGAHELA [1755}

rallied the Indians, and held them to the field for the few minutes that were required to show them what an easy job was theirs. Under cover of the smoke and brush, and aided by their knowledge of the ground and of the science of backwoods warfare, they threw out a long line of hidden skirmishers upon both flanks of the British. From this time forward the battle was mere sport for the one side and deadly slaughter for the other. Two shallow ravines greatly favoured the tactics of the enemy, while a low, densely wooded hill upon the British right front was crowded through the whole fight with howling sharpshooters.

Braddock, when the firing grew hot enough to show that his vanguard was seriously engaged, pressed rapidly up with the main column, leaving Sir Peter Halkett with 400 men, including most of the provincials, to guard the baggage. As the supports reached Gage's company, the latter seem even in so short a time to have received heavy punishment and fell back in some confusion on the new-comers, shaking their steadiness and mixing the men of the two regiments together. Never perhaps was a battle fought more difficult in one sense and in another more painfully simple to describe.

The doubtful moment with the Indians seems to have passed when the main body and the vanguard of the British melted into one. Henceforth it was an almost purely Indian fight and of a nature more astoundingly one-sided than had ever occurred in the annals of backwoods warfare. From right and left and front, and from an enemy that was practically invisible, a deadly fire that scarcely tested the well-known accuracy of the men behind the rifles 
was poured for two hours into bewildered, huddling groups of redcoats. It was a butchery rather than a battle. Anglo-Saxon writers have followed one another in monotonous abuse of these two hapless battalions. The French victor, Dumas, is more generous when he tells us they remained to be shot at for two hours with obstinate firmness. Braddock was a helpless amateur at such work, and his men still more so. Hopelessly disorganized, they crowded together in groups firing wildly into the trees or into the air, or sometimes even into their own comrades.

Braddock proved himself a very lion in combat, but his reckless courage was of no avail. His officers exposed their lives with splendid valour, but the sacrifice was useless. To fight enemies they could not see, and who mowed them down like corn, was something terribly novel to the routine British soldier of that day, brave and staunch though he was amid more familiar dangers. In vain it was endeavoured, by planting the regimental standards in the ground, to disentangle the medley. It was in vain that officer after officer gathered together small groups of men and led them into the teeth of the storm. They were picked off with deadly accuracy, and their followers, bereft of leadership, thrown back upon the slaughter pen. Among others, Burton, whose name was the last spoken by Wolfe's dying lips four years later on the Plains of Abraham, led a hundred men against the fatal hill, but fell wounded in the attempt. One may ask, perhaps, whether bayonet charges, however well delivered, would have availed much against so widely scattered and so nimble a foe in the blind depths of 


\section{HALKETT AND THE REARGUARD}

the forest. Backwoods warfare against the most formidable savage warrior that the world has ever seen was an art in itself that only much backwoods training could acquire. The Red Indian knew no fear. He seldom threw his life away, like equally brave white men, to no purpose, as war with him was a game to be properly played, and this perhaps made him more dangerous. He was liable, too, to moods and tempers; but when he made war in earnest he was terrible, and was always at least equal to the same number of picked backwoodsmen in a stand-up fight. Braddock's men were not picked backwoodsmen, and war on the Ohio was very different from war in Flanders. On this dire occasion the only savages that could be seen were those whose lust of trophies outdid their caution and urged them to rush out and risk the random fire while tearing the scalp from the bleeding heads of dead or wounded soldiers.

British officers as well as colonials who were there have declared that no pen could describe the scene. One actor in it wrote that the dreadful clangour of the Indian war-whoop would ring in his ears till his dying day. One can imagine the packhorses, stung to madness by bullet-wounds and fright, stumbling about among the dead and wounded, adding their dying shrieks to the general uproar, and the cattle, smitten by the fire of both sides, rushing terror-stricken through the woods. At the tail of the column towards the ford and in rear of the baggage Halkett's 400 men, pressed by the advanced points of the Indian flank fire, were faring somewhat better, though Sir Peter himself was killed, and his son, while trying to raise him, fell dead by his 
side. Most of the hundred or so Virginia riflemen, about whose action in this fight a good deal of fable has gathered, were here. They did their duty, and fought gallantly behind trees according to backwoods custom. But the contemporary plan of the battle shows the attack on the rear guard to have been far weaker than where the mass of the demoralized redcoats drew the bulk of the fire.

The pandemonium had lasted over two hours. Only the wagoners and axemen so far had fled. Washington, in the thick of the fight, had nobly seconded his chief's endeavours. He was still unhurt, though several bullets had passed through his clothes and two horses had been killed under him. Braddock, hoarse, hot, smoke-grimed, and stung with the bitterness of defeat, at last gave the signal for retreat. $\mathrm{He}$ was riding his fifth horse, and at this moment feil from it with a ball in his lungs. Orme, though himself severely wounded, and Captain Stewart, a Virginian, ran to his assistance. He begged to be left to die where he was, but first in a tumbril, and then on a led horse, he was forced along amid the general flight that had now commenced.

Everything was abandoned to the enemy-wagons, guns, cattle, horses, baggage, and $£ 25,000$ in specie, while scores of helpless wounded were left victims to the tomahawk and scalping knife. The long strain once loosened, it became a race for life by every man who could drag his legs behind him. Regulars and provincials splashed in panic and in dire confusion through the ford they had crossed in such pomp but three hours before. Arms and accoutrements were flung away in the terror with which men fled from those ghastly shambles. A few Indians 


\section{A HEADLONG FLIGHT}

followed the fugitives into the water, but none crossed it. There was no pursuit; with such a wealth of spoil and scalps on the battlefield, it would not have been Indian tactics.

Braddock, though suffering from a mortal wound, made an effort with his surviving officers to gather some men together and make a stand beyond the first ford. It was useless, however, and they soon found themselves alone. Beyond the second ford another attempt was made with no more success. From here Washington, Braddock's only uninjured aide-decamp, was sent forward to Dunbar's camp, over sixty miles away, to hurry on help and provisions for the wounded. So fast did the foremost fugitives travel that they arrived there the following night, spreading dismay and consternation among the 600 men in camp, great numbers of whom being provincials, deserted and went home. The survivors of the tragedy came dropping in throughout the next two days, many of them hatless, coatless, and without arms. Wagons, medicines, and supplies were sent out along the trail, while Braddock, borne in a litter by two men, whom, Orme tells us, he had to bribe with a guinea and a bottle of wine, lay silent and suffering.

Even the dying hours of the gallant bulldog have been made the theme of much fanciful dialogue and garnished with fictitious utterances of grief at the disaster, and remorse for his supposed obstinacy and rashness. That he twice tried to arrest the stampede, and then took measures for the comfort of the wounded, is all that we know for certain of his last hours. He was unconscious at Rockfort, where it was decided to retire to Fort Cumberland, 


\section{5] BRADDOCK BURIED IN FOREST}

and as the wagons were required for the wounded, and the enemy were expected, the guns and stores that could not be moved were destroyed. At the Great Meadows, a stage beyond, Braddock died. $\mathrm{He}$ was buried there beneath the forest leaves, Washington reading the funeral service over his grave, while wagons were rolled over the fresh mould lest his remains should be found and desecrated. Twenty years later, when the wilderness had given way to civilization, his bones, recognised by the articles buried with him, were accidentally unearthed by a farmer's spade, and found a strange and discreditable resting-place in a glass case at a local museum.

Braddock, to be sure, was no great general. He was sent to carry out an undertaking, arduous and unprecedented in British experience, and did his best in the face of immense difficulties, human and physical. Both he and his people had perhaps grown a little too confident after crossing the second ford. Till then, however, he was entirely successful, and even so it was no ambush in the ordinary sense of the term. With his scouts farther forward he would have had, it is true, a little more notice; but under no circumstances were his regulars qualified to face even a lesser number of Indians in their native woods, while there were not 200 provincial combatants on the field of battle, and many of these had no backwoods experience whatever.

Out of 89 officers, 63 were killed or wounded. Of about 1,300 rank and file, actual combatants, not 500 came out unscathed, the greater number of the remainder being killed. Many were carried off to torture and death by the Indians, who are variously 103 


\section{DUNBAR IN COMMAND}

estimated at from 600 to 800 . The French, who stayed with or near them, numbered about 70, while the 150 Canadians, as we saw, fled early in the fight. The loss of the enemy in killed and wounded was under fifty. The effect of this battle, which neither before nor since has had any exact parallel in British history, was prodigious. Shame and humiliation was felt in England, unbounded exultation in France, while the American colonists' faith in the invincibility of British soldiers was permanently shaken.

The victorious French at Fort Duquesne were scarcely less astonished than elated. We have plenty of written evidence how precarious they considered their position, and with what doubtful hopes of success they left the fort on the morning of July 9th. The blow in itself was bad enough; but Dunbar, a most indifferent soldier, and excusably regarded at the time as something worse, now succeeded to the command of the shattered force, and behaved as if the terror of the tragedy had entered into the very souls of himself and his troops. The effect of it upon the Indians was this time not merely a moral but a physical one, for it left the entire frontier of four colonies at their mercy. Dunbar, however, was not happy till he reached Philadelphia, whence he soon afterwards embarked with his men and sailed away for the north.

There was now a tremendous outcry and a general panic. The Indians, hounded on by the French, and swarming in from the north and west, frequently led, too, by Canadian partisans, threw themselves upon the almost defenceless frontier of Maryland, Virginia, and Pennsylvania, and rolled it back amid an orgie 
of blood and fire and tears; while Washington, in command of 1,000 ill-disciplined and badly-officered militiamen, was set the hopeless task of defending a line nearly 400 miles in length.

He was only three-and-twenty, but was regarded as the natural protector of the colonies now threatened, and his letters from the western settlements of Virginia throughout this autumn, winter, and spring give a harrowing picture of the Indian terror that he was endeavouring to combat. From the thrifty settlements of the Scotch Irishmen, and the more adventurous among the Germans which were thickly sprinkled along the eastern troughs of the Alleghanies, came flying in crowds, horse, foot, and wagons, through the mountain passes. "They come through by fifties at a time," writes Washington, "and talk of surrendering to the French if no help comes from below." Braddock's road from the Ohio he speaks of as being beaten hard with moccasined feet, as if an army had been over it, while all the Western forests were alive with Indians. In Maryland, a little later, he counted 300 wagons in three days hurrying from the wasted settlements. From North Carolina to Western New York men were scalped and murdered by hundreds, and women and children in still greater numbers either treated in like fashion or driven into captivity behind the Alleghanies. The tears and supplications of the refugees were a daily torment to this at once tender and brave-hearted young leader of men, who chafed at the impotence to which he was consigned by bad and inefficient soldiers, worse officers, and a lack of everything but scurrilous abuse.

Braddock himself probably never used in conversa105 


\section{MIDDLE COLONIES PARALYSED}

tion much stronger language than Washington has left in writing of the criminal indifference at this moment of his fellow-colonists who pulled the wires or held the purse-strings. A feeble line of blockhouses was built along the frontier from the Hudson to the James, but the young Virginian commander notes with fine scorn that their militia garrisons take good care to stay inside them, though a bold forward policy was the only hope of successfully combating invasion. Landon Carter, head of the most famous and wealthy family in the colony, is equally trenchant, and swears that if there was an active king upon the throne of France he could conquer the whole country up to the Atlantic with ease. The Indian terror lasted for nearly two years, during which the destruction of life and property was awful, and the accompanying details ghastly. It was complicated, moreover, in the south by a continual dread of a servile rebellion. In Virginia alone were 120,000 negroes whose minds were insidiously poisoned with the notion that a French triumph would ensure their freedom. When the French influence was dead, and the Western Indians in after years were left face to face with the sons and grandsons, and even husbands and brothers, of the victims of 1755-56, a deadly reckoning was taken. ${ }^{1}$ As the Scotch-Irish vanguard of American civilization slowly pushed their way across the Alleghanies towards the fertile plains of Ohio, Kentucky, and Tennessee, it would be ill guessing how much of fierce revenge for some unforgotten tragedy nerved the arms of the sinewy halfPuritan, half-lawless borderers who "won the West."

1 Mr. Theodore Roosevelt's book The Winning of the West, treats of this later period in an exhaustive and fascinating manner. 


\section{5] EFFECTS OF BRADDOCK'S DEFEAT}

\section{CHAPTER IV}

$\mathrm{B}^{\mathrm{RADDOCK} \text { 'S crushing defeat near Fort Duquesne }}$ $B$ resounded throughout North America to its uttermost limits. Nor was the effect produced on the Northern colonies by any means only a moral one. On the contrary, it contributed very materially to the failure of both those expeditions to the northward which were designed to support Braddock; namely, the one undertaken by Shirley against Niagara, and the other, led by Johnson, against Crown Point, on Lake Champlain. In the first place, the news of the catastrophe on the Monongahela arrived in the north before either corps was ready to deliver its attack, and greatly disheartened the militia who composed them; and secondly, the capture of Braddock's papers revealed to the French the secret plans of their enemies, and enabled them to take measures for their frustration.

Shirley, the spirited Governor of Massachusetts, though but an amateur soldier, had been commissioned a general, greatly to his delight, and was now by Braddock's death Commander-in-Chief in North America. The Marquis de Vaudreuil, the new Governor of Canada, had in the meantime arrived from France, with 3,000 regulars, including the regiments of Bearne, La Reine, Guienne, and Languedoc, who were to earn much well-deserved 


\section{THE MARQUIS DE VAUDREUIL [1755}

renown in the coming war. Of Vaudreuil we shall hear a good deal, seeing that he remained in office till the closing scene, and signed the capitulation of the colony to Great Britain. It will be enough for the present to say that he was fiftyseven years of age, the son of a former governor, and in consequence a Canadian by birth-a fact which gave him a strong colonial bias in all matters of jealous contention, and they were many, between the sons of old and new France. For the rest he was a man of second-rate ability and of no military capacity, though he aspired to much. He was of a jealous, vain, and somewhat petty nature, but patriotic and hardworking to a fault, and had previously been Governor of Louisiana. The commander of the forces was Dieskau, a German baron, who had long served in the French service, a good, sound, capable soldier, but of no striking talent, and his career in America was destined to be brief.

Of the subsidiary expeditions of the British in this year, 1755, I shall not speak at such length as the schemes involved and the number of troops collected for them might seem to warrant. Partly from the inexperience of all concerned, and partly from their premature discovery by the French, both undertakings were practically fruitless. I purpose, moreover, having in view the limits of this little book, to dwell chiefly on the more luminous and decisive conflicts of the war, and not to attempt the elaboration of fruitless campaigns that would weary the reader with an unavoidable monotony of detail, though some brief notice of them is essential to the story.

Shirley's thwarted undertaking against Niagara 108 



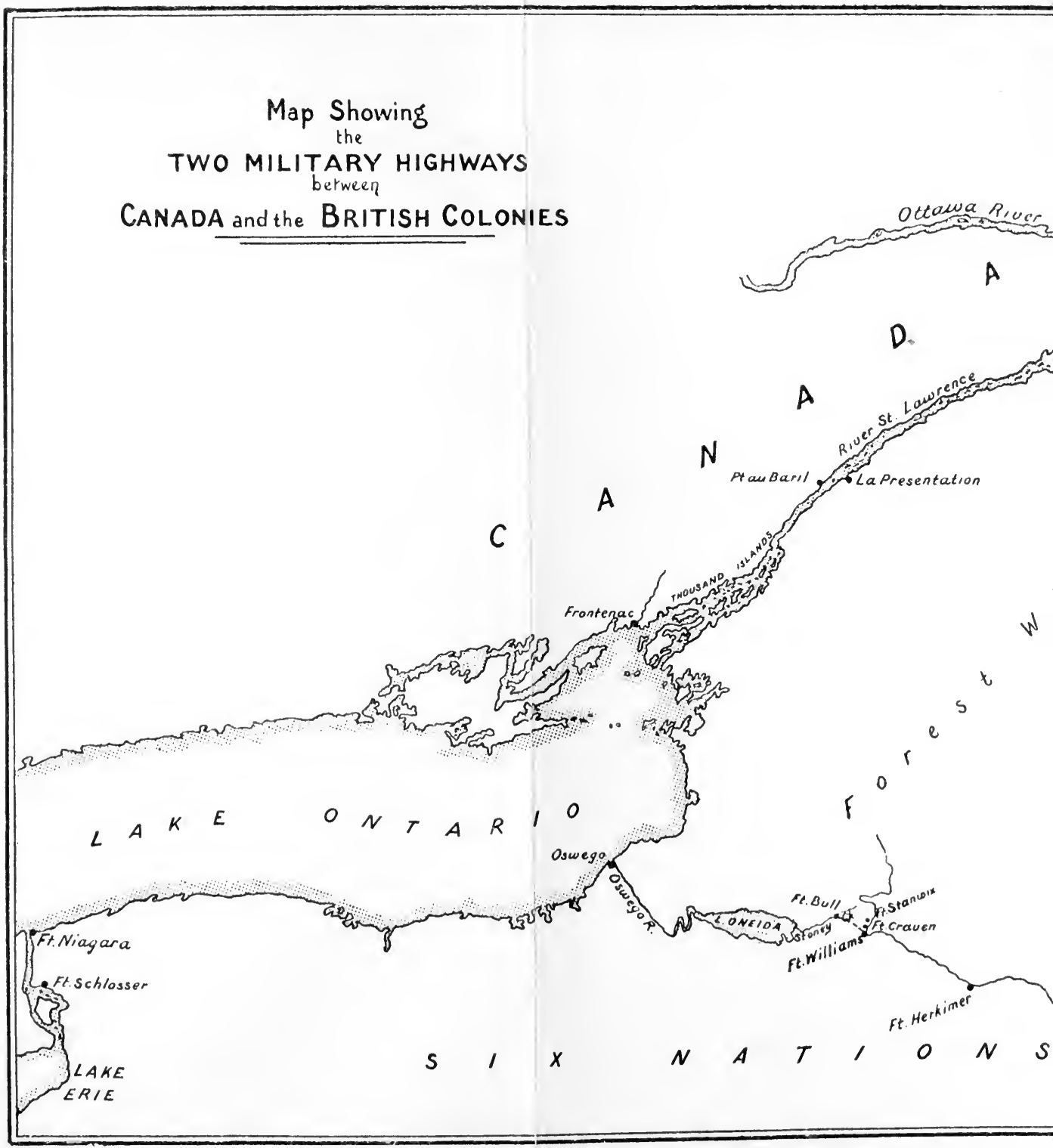




\section{5] THE TWO ROUTES}

had gone by way of the more w great routes which led to Canac started from Albany, on the $\mathrm{Hu}$ frontier town may be described a of a right-angled triangle, one due north to the St. Lawrence Canada, while the other ran nearl Ontario, tapping French territory tion, but in the path of its chief $t$ the West. The base of this $t$ represented by the course of Both these routes - the nol hundred miles in length, the less-lay through a rugged, fore unpeopled wilderness. They we arteries formed by lakes and str narrow watershed here and the continuity. There were numerol shallows to be portaged; ${ }^{1}$ but, sense, they were navigable rout obstacles, which at this early sta great, they were, nevertheless, channels by which French or En conduct serious operations agains Between Canada and the fron New York and New England th able "trails," quite adequate f rangers or Indians; but for the ing of the situation in North $\mathbf{A}$ this whole period the reader cann before his eyes these two great $m$

1 "Portage," a convenient colloquia used, either as a noun or verb, both it Canada. 


\section{Map Showing \\ TWO MILITARY HIGHWAYS berween \\ CANADA and the BRITISH COLON}

$\angle A K E$

O N T A A R

Ft. Niagara

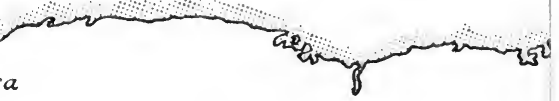

Fl.Schlosser
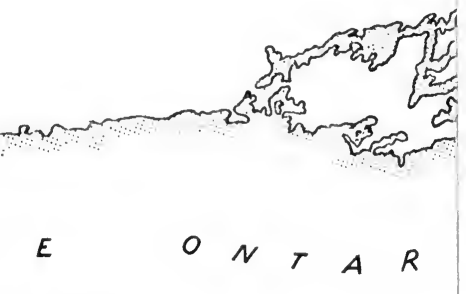


\section{5] THE TWO ROUTES TO CANADA}

had gone by way of the more westerly of the two great routes which led to Canada. Both of these started from Albany, on the Hudson River. This frontier town may be described as lying in the apex of a right-angled triangle, one side of which ran due north to the St. Lawrence and the heart of Canada, while the other ran nearly due west to Lake Ontario, tapping French territory behind its civilization, but in the path of its chief trading highway to the West. The base of this triangle is roughly represented by the course of the St. Lawrence. Both these routes - the northern some two hundred miles in length, the western somewhat less-lay through a rugged, forest-clad, and almost unpeopled wilderness. They were, in fact, natural arteries formed by lakes and streams, with only a narrow watershed here and there to break their continuity. There were numerous rapids, too, and shallows to be portaged; ${ }^{1}$ but, in the backwoods sense, they were navigable routes. With all their obstacles, which at this early stage were many and great, they were, nevertheless, the only possible channels by which French or English armies could conduct serious operations against each other.

Between Canada and the frontier settlements of New York and New England there were innumerable "trails," quite adequate for war bands of rangers or Indians; but for the proper understanding of the situation in North America throughout this whole period the reader cannot keep too clearly before his eyes these two great military waterways:

1 "Portage," a convenient colloquialism still universally used, either as a noun or verb, both in English and French Canada. 
the one running north, the other west, with the old Dutch frontier town of Albany standing in the angle - the base of supply for both.

The extremity of the western route was Oswego, where the flourishing town of that name now looks out upon Lake Ontario. In those days it was a remote trading station, rudely fortified, and occupied for the past thirty years by the British, to the constant vexation of their rivals, who regarded the western lakes as wholly within their sphere. The way to Oswego led up the Mohawk River, which joined the Hudson near Albany, and for batteaux and canoes was more or less navigable to the headwaters, whence a four-mile portage over the watershed led to Lake Oneida. From this beautiful sheet of water the Oswego River rolled down to Lake Ontario. Shirley now really opened this route for the first time. At the head of 1,500 men, collected, supplied, and organized with difficulty, he pushed his slow way to Oswego, which was to be his base for an attack upon Niagara, the most important station the French held in the West. His force consisted of two battalions of raw recruits raised in the colonies, but paid by the Crown, afterwards the 50th and 51st regiments of the line, and some artillery. The delays for obvious reasons had exceeded all calculation, and it was late in August before Shirley was ready to leave Oswego. But he then found that the French, having got warning of the British plans from Braddock's captured correspondence, had thrown large reinforcements into Fort Frontenac, which confronted him not fifty miles away upon the northern shore of the lake. Frontenac was a fortified trading post of much 


\section{5] JOHNSON OF "MOUNT JOHNSON"}

the same type as Oswego and the original of the old and important Ontario town of Kingston. Shirley dared not now move. To have abandoned Oswego for an attack on Niagara would have left the former at the mercy of thirteen hundred efficient and well-provided French soldiers, who had gathered at Fort Frontenac. So there was nothing for it but to work out the rest of the season upon the poor fortifications of his present position, and as the winter approached to return to Albany. Seven hundred men were left at Oswego as a garrison under Colonel Mercer, of whose fate we shall hear later, and in the meantime a little more space must be given to Johnson's operations against Lake Champlain, though they were equally futile. Just a word, however, must be said of the man himself, since he was a famous character in his day and played a unique and somewhat romantic part. He was now about forty years old, was a native of County Meath, and acted as agent for his uncle, Sir Peter Warren, who had made a speculative purchase of an immense tract of wild forest land in the Mohawk Valley. Here Johnson dwelt in a large rambling mansion among the woods known as Mount Johnson, with an Indian wife, the sister of a famous chief. $\mathrm{He}$ acquired an extraordinary ascendancy over the Indians, here represented by the warlike Six Nations, the scourge alike in former days both of French and English, but now this long time, as we have said, allies of the latter, though strictly passive ones and much shaken by the growing prestige of France. He spoke the Mohawk language and entertained their people in lavish fashion. "This singular man," says Mrs. Grant, of Laggan, who was 


\section{JOHNSONAPPOINTEDTO A COMMAND [1755}

brought up at Albany, and remembered him, "lived like a little sovereign, kept an excellent table for strangers and officers, and by confiding entirely in the Indians and treating them with unvaried truth and justice, taught them to repose entire confidence in him."

The Albany traders who formerly represented the colonies in all official dealings with the Indians, had by bad faith brought them to the verge of a rupture. The latter hailed with delight the appointment of their favourite as Indian Commissioner, and Johnson himself, thoroughly appreciating the grievances which had almost driven them into the arms of the French, soon had them under a control that remained unshaken throughout the war. He was a versatile kind of genius, a big, breezy man abounding in energy and common-sense. He could hold his own in a grave council of colonial Governors, or, if need be, could drink and shout and paint his face and dance the war-dance with the wildest of Mohawk warriors.

In the dearth of skilled commanders, Johnson, who, with all his ready capacity, had no military experience whatever, was now made a general, and given the command of 6,000 provincial troops. His instructions were to drive the French from Lake Champlain, and to occupy Crown Point, a promontory of strategic importance on its south-western shore. As a preliminary to the campaign, Johnson collected a thousand of the Iroquois warriors at his manor, feasted them with oxen roasted whole, and indulged them with an orgie of eloquence extending over three days, at the end of which period he flung down the war belt. So honeycombed, however, 


\section{5] THE NEW ENGLAND MILITIA}

had even the Six Nations been with French intrigue, that only a third of Johnson's guests responded to his appeal. The rest were deterred by having relatives employed on the French side.

The troops for the Northern expedition, like those of Shirley's, assembled at Albany. Of the 6,000 voted, 4,500 came from the ever-martial colony of Massachusetts. These raw New England militiamen, whatever their spirit, must not be regarded as very formidable troops. They were mostly recruits, and all amateurs in regular warfare. Nor were most of them efficient in a system of their own like the South African Boers. A few only were experienced bush fighters, the greater part being hard-working farmers, mechanics, or fishermen. They had no discipline and only a few had uniforms. Each soldier brought a gun with him, which he knew how to use with ordinary skill, also a tomahawk to serve in lieu of a bayonet, at close quarters. The men were impatient under control, and were imbued with a constant longing for home, where the plough stood idle in the furrow or the hammer silent in the forge. They had no military science, no elementary knowledge of camp sanitation, and as a premium on indiscipline they elected their own officers, who with rare exceptions knew little more than the men they commanded. The French Canadians held them in a contempt that was exaggerated by the vanity of their race, and moreover hated them heartily as heretics. But with all this they were tough and hardy, and, one need scarcely say, possessed of the inherent bravery of their stock. From their ranks, too, could always be gathered small bands of men who combined superior marksmanship and a practised knowledge of bush fighting, 


\section{THE CHAMPLAIN ROUTE}

- of la petite guerre, as the French term went-with a resolute and incomparable daring that makes some of their enterprises throw fiction into the shade.

Dieskau, whose first intention had been to proceed up the St. Lawrence to Lake Ontario and seize Oswego before Shirley could entrench himself there, now hurried back, and ascending the Richelieu River to Lake Champlain, occupied Crown Point with a force of 3,500 men, of whom 700 were regulars, 1,600 Canadians, and the rest Indians. Johnson's force at Albany was far short of the estimates, but it was not lack of numbers that was his serious difficulty. For a raw general with a raw army and a wilderness to face, unsustained by any organization worth mentioning, the difficulties of transport and commissariat were immense. His route, which became from this time forward so memorable a one, began by following the course of the Hudson due north from Albany for some forty miles. This much of it was comparatively simple, being by water, with but few portages. Then, however, where the great river turns sharp to the west, the line of march left its banks, and continuing northward, crossed the twelve miles or so of densely timbered upland that separated it from the headwaters of Lake George. Once launched upon the bosom of the most romantic sheet of water in North America, canoe or sloop might float onward towards Canada beneath the mighty shadows of the Adirondack Mountains, without let or hindrance but a gale of wind, for over thirty miles. At the foot of the lake a river, broken at places with rapids and shallows, pursued a short but tortuous course till Lake Champlain opened out its shining bosom and presented a clear 


\section{5] JOHNSON MARCHES}

sailing stretch of some sixty miles. Thence from its foot the Richelieu or Sorel River in another stage of about equal distance led to the St. Lawrence and the heart of Canada. The whole of this natural route is so curiously direct that a ruler laid due north upon the map from Albany, or indeed from New York to Montreal would indicate with sufficient accuracy this famous military highway of bygone America.

But it is only with Lake George, "the Silvery Lake," the "Horican" of the Indians and Fenimore Cooper, that we have now to do, and even in such case only with the head of it. Johnson had probably no more than 3,000 men actually with him, and these gave his inexperienced wits enough to do in the handling, feeding, and pushing them forward through so rough a country. His main difficulties of course began when he left the Hudson, and had to carry cannon, stores, and boats over the shaggy ridges which led towards Lake George. The landing-place at once became a point of the utmost strategic importance, and here the general left Colonel Lyman with 500 men to build a fort, named at first after that doughty New England warrior himself, but shortly re-christened by the loyal Johnson after a prince of the blood, and known to future generations as Fort Edward. Johnson himself, with the rest of his rustic army and 300 Mohawk Indians, cut their way painfully through the woods and deposited their boats, stores, and guns on the banks of the uppermost bay of Lake George. Here they proceeded to throw up fresh intrenchments, which developed later into Fort William Henry of sinister memory.

Dieskau in the meantime, learning from his 


\section{DIESKAU ADVANCES}

scouts that Johnson was fortifying both ends of the carrying place, laid his plans. Crown Point, the fortified post on a promontory of Lake Champlain which he occupied with his army, was fifty miles to the north. It had worried the frontiers of the New England colonies which lay to the east of it for twenty years, and was Johnson's point of attack, as already indicated. Dieskau, however, was not likely to act on the defensive with a force equal in numbers and individually superior. Selecting a body, therefore, of 200 regulars, 680 Canadians, and 600 Indians, he served them with rations for ten days, and led them rapidly forward to meet Johnson. A glance at the map will show how Lake Champlain throws out a long narrow tail southward, known as Wood Creek, and running parallel with Lake George for almost its entire length. It was up this waterway in canoes and boats that Dieskau led his force. Landing near its head, they proceeded to march through the woods till they struck, about at its centre, Johnson's new road from the Hudson to the lake, where they intercepted British messengers and learned the state of affairs. It was now a question of which encampment they should attack. Being informed, though falsely, that there were no cannon at the lake fort, they decided for this reason on attacking it. Johnson, in the meantime, had heard of the French movements, and despatched a thousand men under Colonel Williams into the woods to find and oppose them. Hendricks, a famous Mohawk chief with Johnson, protested at the inadequate size of the force- " too few," he said, "to be successful, and too many to be killed." $\mathrm{He}$ nevertheless consented to face the dangers his British allies were so rashly courting, with 200 of his 116 


\section{AN AMBUSCADE}

warriors. Too old and too fat to walk, the brave Indian rode with the rest, mounted on a pony, and was one of the first to fall. Williams, "colonial" though he was, seems to have marched his force through that blind and tangled country with a contempt for ordinary precautions, such as the much-abused Braddock never dreamt of. Dieskau, on the other hand, feeling the way carefully with his scouts, had ample warning of the British approach, and received them in a well-laid ambush with a success that was only saved from being complete by some of his Indians opening fire a little prematurely. It is said that they saw some of their Mohawk relatives in the van of the advancing British, and took this method of warning them. However that may be, the New England soldiers were taken even more by surprise than Braddock's vanguard, and like them, though still more rapidly, the front ranks were driven back in confusion upon their supports by a withering fire from an almost invisible enemy. In Dieskau's own words, "the column was crumpled up like a pack of cards." They did not remain huddled helplessly together to be shot at as did Braddock's men, but after a sharp brief struggle, in which Williams and Hendricks both fell, they turned and ran for the fort, the French and Indians hotly pursuing. But Johnson, hearing the sound of battle drifting rapidly his way, sent out 300 men to stem what was evidently a hot retreat. This they accomplished with sufficient success for the British to bring in their wounded. There was but just time to raise hasty barricades of inverted batteaux and trunks of trees. The forest unfortunately still grew close to the lines of the embryo 


\section{THE FRENCH REPULSED}

fort, and there was now no chance to do any clearing. Could Dieskau have pressed on at once, his men would have carried the camp. But neither Indians nor Canadians were fond of storming positions, and, like the Boers of to-day, threw themselves into cover at once, though in their case trees took the place of rocks. The white-coated French infantry, however, went bravely on till the unexpected fire of artillery, well served by Captain Eyre, drove them also into the shelter of the woods. A hot musketry engagement now ensued. Johnson's militiamen recovered from their panic, and, partially protected by rude breastworks, fought well and stoutly. In time the rifle fire, supported by the artillery, began to tell so unmistakably upon the enemy, that the New England men, taking heart of grace, leaped over their barricades and swept down upon the foe with tomahawks and clubbed muskets, driving them ultimately from the field. Johnson was wounded; Dieskau was not only wounded, but captured, and as he was sitting helplessly against a tree, with three bullets already in his legs, a soldier seeing him levelled his piece, and in spite of his victim's protests, deliberately shot him through both thighs. Fortunately for the credit of the New Englanders, the rascal turned out to be a French deserter. The unfortunate general was carried to Johnson's tent, who, though in a bad plight himself, behaved with a generosity that Dieskau never forgot.

There was a prodigious clamour among Johnson's Indians for the French commander's life in atonement for that of their chief Hendricks, who had been bayoneted in the fight of the morning. It was all their popular and powerful leader could do to 


\section{5」 DIESKAU A PRISONER}

save his wounded prisoner and guest from their direful clutches. "What do they want?" inquired Dieskau of Johnson, with a naïvete not yet rubbed off by North American warfare. "Want," replied Johnson, "to burn you, by God! eat you, and put you in their pipes and smoke you ; but, never fear, you shall be safe with me, else they shall kill us both." When able to travel, Dieskau was sent with a strong armed escort to the Hudson, and in due course to England as a prisoner, where he remained till the peace, a wreck more or less from his wounds, but always cheerful and full of gratitude for the kindness shown him in America. He died in 1767.

While the fight around the crude beginnings of Fort William Henry was in progress, several hundred of Dieskau's Indians and Canadians had fallen back on the scene of their morning's victory, intent on the scalps and plunder that in the hurry of the forward movement they had been compelled to forego. While thus engaged, a party of 500 British from the new fort on the Hudson caught them unawares, and after a sharp fight utterly routed them, though the leader of the victorious party, Captain M'Ginnis, was killed.

This repulse of the French, coming so soon after the terrible disaster at Fort Duquesne, was made the most of both in the colonies and in Britain. It was forgotten that the real object of the campaign was to seize and occupy the fortress which commanded Lake Champlain and the road to Canada; whereas Johnson's victory, though highly creditable to a militia who had never been under fire, merely repulsed the French in their attack on British territory. The capture of their general beyond a doubt gave the 


\section{A BACKWOODS BARONET}

success much éclat. At any rate Johnson was made a baronet, presented with $£ 5,000$, and enjoyed whatever distinction there may have been in the title of "Our only hero," bestowed on him by Horace Walpole. The loss of the British in the day's fighting was about 250, of whom the greater part were killed, the third Massachusetts regiment alone losing no less than 70 men, including the colonel and eight officers. The French loss was 120 killed and 123 wounded.

The new backwoods baronet, however, was regarded by many colonists as too much inclined just now to rest upon his laurels. His recent success, they thought, might well have justified a dash forward on Crown Point, and Colonel Lyman, chief of the New England troops, was eager for it. Johnson, however, declared that his men were not fit for any such adventure, that they were ill clad, discontented, and shaken in morale by the vigour of the late attack. Shirley himself urged it, but Johnson's honours had created a quite pardonable jealousy in the breast of that eager though unsuccessful amateur. Johnson, moreover, was wounded, and would probably have had to depute the command to his rival Lyman, and Sir William, as we now must call him, like Shirley, was undoubtedly very human. He decided, therefore, to utilize what energies his men, in their somewhat miserable condition, still possessed, in building Fort William Henry. When the close of November put an end to the work, three thousand men in a state of semi-mutiny and half frozen for want of warm clothing in that rigorous northern clime turned their backs for the winter on the leafless snowpowdered forests and ruffled waters of Lake George 


\section{5] IN WINTER QUARTERS}

and scattered each man to his shop or homestead to tell his tale of war and hardship and glory.

Seven hundred men were left to garrison and strengthen the new fort, while at Ticonderoga on Lake Champlain, forty miles to the north, the French were equally busy with axe and saw. Here, amid the hush of the Northern winter, amid ice-bound lakes and mighty mountains wrapped in their mantle of snow, we will leave the outposts of the two rival nations to face each other, and to prepare as best they may for coming fights that were to prove bloodier and fiercer than any yet dreamt of either by the Canadian habitant or the Massachusetts farmer.

But there was yet a fourth enterprise undertaken by the British in this notable year, 1755, which, though far removed from the scene of the others, and in itself neither bloody nor glorious, had at least the merit of being decisive.

I have already spoken somewhat fully of the troubles with the Acadians, and made brief allusion to the crowning scene of their forcible removal, which occurred this year. The unquenchable yearning of the French to recover their long-lost province was by no means lessened by their successes elsewhere. The strong fort of Beauséjour, that they had erected on the neck of the isthmus, in doubtful territory, but commanding the most troubled part of the English dominion of Nova Scotia, became a busy scene of intrigue and action. Nearly 2,000 men, French regulars and insurgent or outlawed Acadians, besides large bands of Indians, were gathered either inside or within hail of it; while at the far end of the province the great naval and military post of 


\section{ACADIAN TROUBLES}

Louisbourg boded mischief no less dangerous. The recent English settlement of Halifax, now the capital of the province, and a few isolated forts containing each their handful of men, represented all the power available for resisting a French attack, and protecting the scanty English settlers from the constant raiding of Acadians and Micmacs, hounded on by blatant priests and erafty politicians. Shirley, before starting on his luckless expedition to Niagara, had arranged with Colonel Laurence, Governor of Nova Scotia, to take the bull by the horns and sweep Beauséjour and its whole nest of hornets out of existence. The English Government gave their assent, but Laurence had no troops to speak of, and once again the resourceful colony of Massachusetts was appealed to, and, as usual, not in vain. Colonel Monckton, second in command to Laurence, and whom we shall meet again on the Plains of Abraham, was sent to Boston, with a commission to raise two regiments of 1,000 men each. The recruiting was entrusted to Colonel Winslow, a provincial officer of good sense, position, and some experience, who in a short time paraded 2,000 hardy rustics before the admiring eyes of their fellow-colonists upon the wharfs of the Puritan city. The muskets, however, which were due from England, were much less punctual than the men, and it was near the end of May before the transports cleared Boston Harbour, amid the cheers of a populace who only ten years previously had in the same hearty fashion sent out the victors of Louisbourg. On the last of the month the fleet was forging up the Bay of Fundy, and on the 1st of June, to the dismay of the French, 


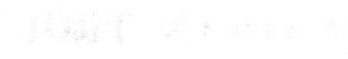




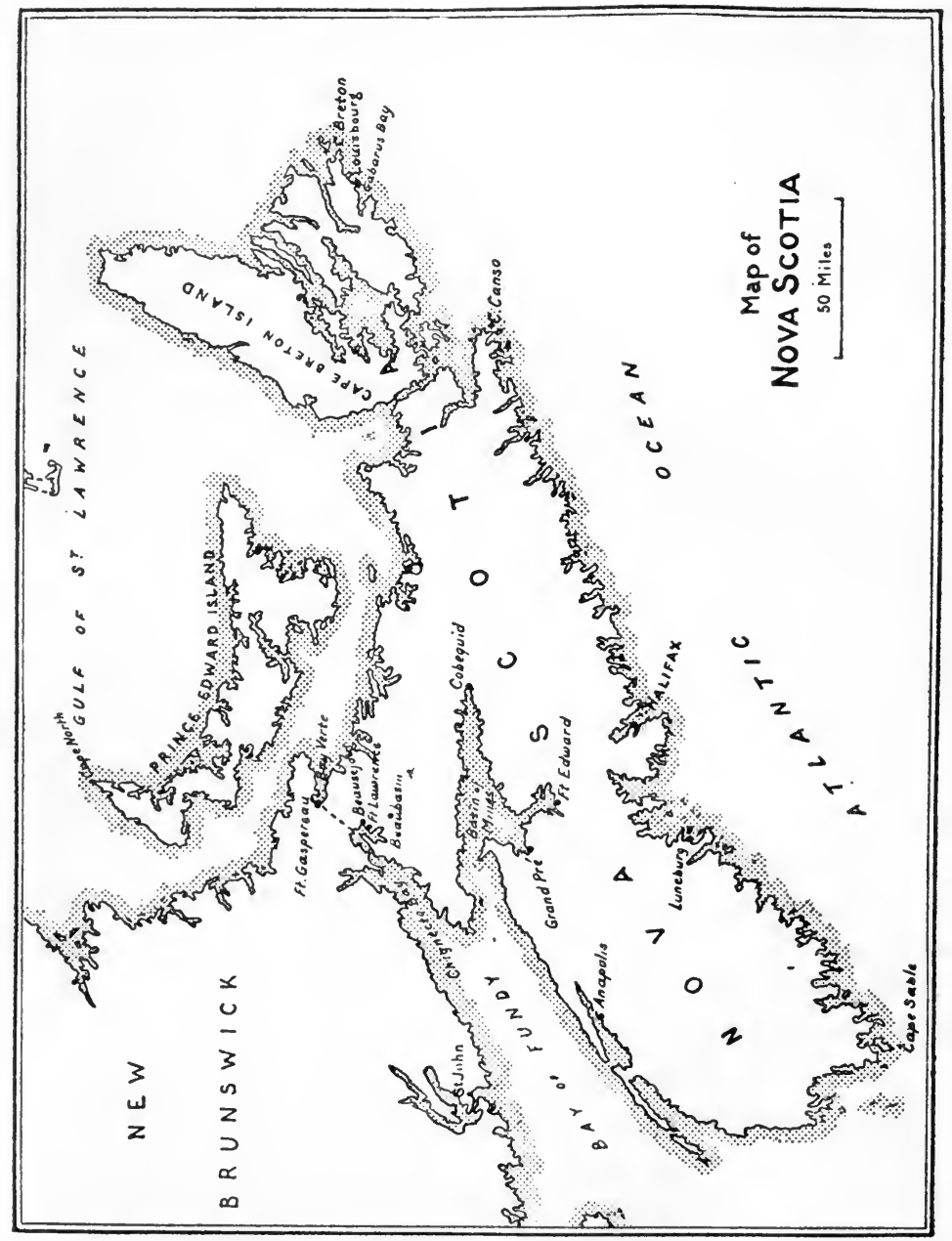




\section{5] NEW ENGLAND TROOPS}

dropped anchor off the mouth of the Missaquash, which divided their chief stronghold from its English rival, Fort Laurence.

Beauséjour was a well-planned fort of five bastions, and mounted with 32 guns and mortars. The nucleus of its garrison was some 150 regulars of the colonial marine, commanded by De Vergor, a captain in the same corps-a person of indifferent principles and no compensating capacity. The fort was an outpost not merely of French strength, but also of French weakness in the shape of financial corruption. It ranked high in the list of good things doled out at Quebec to those who by personal services-sometimes creditable, sometimes unmentionable-to the governing clique, earned their due reward. De Vergor seems to have come under the latter category. None the less, however, did the allpowerful Bigot, Intendant of Canada, at once his debtor and his patron, urge him in a delightfully candid letter, still extant, to make hay while the sun shone, and out of his plunder purchase an estate in France near him, his loving correspondent. The usual method of enrichment seems to have been the familiar one of charging the King of France for supplies that only existed on paper, and selling a considerable portion of such as were actually forwarded for free distribution.

De Vergor, however, did not develop into a proprietor of French vineyards and forests. On the contrary, he was arraigned for misconduct in the affair I am about to describe, though we shall find him figuring again and at a critical moment before Quebec, with scarcely more credit. The first intimation that on this occasion De Vergor had of an 


\section{THE FALL OF BEAUSEJOUR [1755}

impending attack was the appearance of an English fleet off the fort. The infamous priest Le Loutre, spoken of in a former chapter, was now with him, and supplied all the energy that De Vergor might be lacking in, and a great deal to spare. Hundreds of Acadians, driven from their homesteads on British soil by the coercion of this savage fanatic rather than by any action of the English, were now wretched outcasts dependent on the none too liberal charity of the fort, and from their very despair useful tools for French aggression. With these and the regular garrison, and as many more from the settlements on the French side, some 1,200 men were mustered. Numbers of the wretched Acadians, seeing an English victory only too probable, begged De Vergor to go through the form of forcing them by threats to fight, so that they might excuse themselves, in the event of defeat, for being in arms against their lawful king. De Vergor grimly replied that he would not only threaten but shoot them if they failed him.

The New England troops in the meantime were landed, and in conjunction with the small garrison of regulars from Fort Laurence laid formal siege to the French fortress, approaching it by parallels and with heavy cannon. They were attacked by Indians and Acadians from without the fort, and much less vigorously by the garrison from within; but Winslow and his sturdy militiamen pressed the siege so strenuously that De Vergor, on hearing from Louisbourg that help was impossible, surrendered in a fortnight. The capitulation was accompanied with some discreditable scenes of drunkenness and stealthy pillage on the part of the French officers, and much open but more venial plunder on that of the 


\section{5] TEMPER OF THE ACADIANS}

miserable Acadians. The fort was occupied by Colonel Scott, of the second Massachusetts regiment with 500 of his men. Winslow with another body crossed the narrow isthmus to the north shore, and took Fort Gaspereau, on Bay Verte, without opposition.

Nova Scotia, so far as military occupation went, was now wholly in British hands. But though rid of pressing danger from French forts and soldiers, it remained a seething hotbed of misery, treachery, and disorder. Its security was of vital importance to the British at this most crucial moment. For, similar reasons its recovery was no less an object with the French. The small handful of British regulars, with the raw and scant militia of the infant Halifax, would be ridiculously inadequate as a protecting force; while the two Massachusetts regiments, in accordance with custom and necessity, were only enlisted for a season. A small force of French invaders, in the present temper of the Acadians, could count on their almost unanimous assistance. Hitherto any of these latter people who had abandoned their farms could return and make their peace without difficulty. Those who had remained at home could at any time insure the continued favour of the British Government by taking an unqualified oath of allegiance to King George, who had treated them with unbroken indulgence, and under whose rule most of them had been actually born. Yet never had these strange people been more generally hostile than now, and at no time, thanks to magnified reports of French successes, had they been so insolent. It is not surprising that the patience of the British authori- 


\section{AN ULTIMATUM DECIDED ON $\lfloor 1755$}

ties at last gave out; and Lawrence, though eminently a just man, was not quite so soft-hearted as some of his predecessors. If the Acadians had professed to have grievances, if they had even invented some, there would have been an opening at least for conciliation. But an attitude induced partly by superstitious terror and partly by intimidation through the medium of Indians and outlaws, and skilfully seasoned with false reports of French victories and conquests, was an impossible one. The French officials in Louisbourg and elsewhere betray in their existing letters the inward shame they felt at being compelled to connive at this heartless ruin of a whole population of ignorant peasants. They begged each other not to let the English officials-with whom, as the farce of peace still existed, they were on civil terms-suspect the part they were playing. But the limit of English forbearance had at last been reached, and the Acadians were to be given their ultimatum.

A certain number of exiles had petitioned for reinstatement, and received it on taking the full oath, but the mass yet awaited the test. Time pressed, and none was lost. Shirley amid his own troubles on the far-off Mohawk was as strong as Lawrence for an ultimatum. The latter, after submitting the matter to his Council at Halifax, communicated his intentions to Monckton, Winslow and the other British officers. In every district it was then proclaimed that an unqualified oath of allegiance would be required from every inhabitant who had not already taken it. The appeal was responded to by deputations from the several districts, all making objections to the terms of the oath, chief 


\section{5] THE ULTIMATUM DELIVERED}

among these being the liability to bear arms. Others made stipulations that the priests should be free from all supervision, which, bearing in mind that they were the political firebrands who were the root of the country's misery, and had already received far too much indulgence, was somewhat audacious; and this more particularly since a Protestant was not allowed even to exist in Canada, fortunately for the future of Anglo-Saxon supremacy beyond the Atlantic. No regret was expressed by the Acadians for the fashion in which they had repaid near forty years of indulgent treatment; no apology offered for the attacks upon English garrisons in conjunction with French troops, nor for the barbarous raiding and murdering of British settlers. Lawrence went so far as to promise them that, for the present at any rate, they should not be liable to military service. It was in vain that firmly and kindly he reminded them of the consistent indulgence shown them by the King of England, and explained how impossible it was that he should tolerate such a grudging return. But it was neither the King of England, nor the King of France, nor any question of race or patriotism, that these infatuated people had in their minds, but the fear of eternal damnation, which the Bishop of Quebec, through his all too zealous missioners, had struck deep into their unsophisticated souls, and the dread of Le Loutre's Micmac Indians.

"Then," at last said Lawrence, "you are no longer subjects of the King of England, but of the King of France. You will be treated as such, and removed from the country." At this they were staggered, and most of them relenting, professed a willingness to take the oath. "No," said Lawrence; "you have had 
your opportunity and rejected it. Such an oath as you would now take, and such loyalty as mere fear extorts from you, is worthless. We shall now have regard solely to the king's interests, and the consequences must rest on your own heads." I have here endeavoured to condense what extended in fact over many interviews, much tedious going to and fro of deputations, and much consultation in the Acadian villages.

It was the middle of July when Lawrence and Winslow commenced that final step which has made such a harrowing picture for the somewhat ill-instructed sympathies of half a dozen generations of Britons and Americans. The troops were divided into four or five bodies, and marched through the province to the chief centres of population, which were mostly on the western shore. The object in hand was kept a dead secret from all but the leading British officers. Winslow had command at Grandpré, and has kept a useful journal of the whole business. September the 5th was the day decided upon for action, when the officer of each district was to summon all its able-bodied men to come and hear the intentions of the king towards them. Accustomed to regard the rare bark of the British Government as infinitely worse than its still rarer bite, they came in a large proportion of their strength, and without a thought of the trap that was being laid for them, to hear what suggestions that benign shadow, the King of England, had to make for their future.

The parish church in most cases was the appointed rendezvous, and there the king's orders were read aloud to them by the officer in command. These were to the effect that all such Acadians as had not already 


\section{5] CONSTERNATION OF ACADIANS}

taken the oath were to be shipped out of the country with their families; that their lands and stock, which at any time till now they could have saved by an oath of allegiance to a king "who had treated them with greater indulgence than any of his subjects in any part of his dominions," were forfeited to the Crown. Their money only, and such household goods as there might be room for in the ships, they were to be allowed to take.

The wretched Acadians were dumbfoundered at the nature of this announcement. Many refused to believe it. They were, however, prisoners, with only too much time before them for the terrible truth to sink into their minds. There was no escape, for outside the churches stood the New England soldiery, in their blue uniforms, with loaded muskets. The number of Acadians secured on this fifth of September varied in the several districts. Everywhere, however, it was supplemented by forays of the British troops, which became no easy matter when the direful news spread abroad. The transports for removing the emigrants were dilatory in their arrivals. Winslow and his brother officers chafed at the delay, for their small divided force was none too strong, and, moreover, as humane men, they heartily detested the job. No hint, however, comes down from any of them that, under the circumstances, there was any alternative, which is significant. There seems, indeed, to have been but one opinion as to its necessity. It is not for us to dwell here on the details of this melancholy deportation. All the women and children who so desired could go, and every care was made to keep together not only families, but so far as possible neighbours. Many did not 


\section{THE DEPORTATION}

believe the sentence would be actually carried out till the first detachments were marched on board ship at the bayonet's point. The whole wretched business occupied over two months. About six thousand in all were deported, while more than half that number were left behind in Acadia, to say nothing of as many more who had fled into French territory. Some of these became practically outlaws, and harassed the British till the close of the war. But their sting was drawn: the province rapidly became in the main British by race as well as by territory, hastened to this end by the fall of Louisbourg, of which we shall hear anon.

The hapless emigrants were distributed throughout the English colonies. That people so profoundly ignorant and bigoted as the Acadians did not flourish when pitchforked thus on to alien soil, is not surprising. Nor is it more so by the same token that the British colonists upon whom they were unceremoniously precipitated, showed no alacrity to receive them. ${ }^{1}$ Their after wanderings, which were wide, and subsequent groupings, are of interest to the American ethnologist, but do not concern us here. It will be sufficient to say that, of all the communities upon whom they were cast, the uncompromising heretics of Massachusetts exhibited most practical charity, while it was the exiles who found their way to Quebec, to their co-religionists and their own countrymen, whose tools they had been, that fared the worst.

${ }^{1}$ In South Carolina, as elsewhere, money was subscribed for their provision; and many of the exiles were bound over to work for upcountry planters. Several outrages were attempted or committed by them, and a body of fifty seized a sloop and put to sea with a view to returning to Acadia. 


\section{5] EXCUSES FOR THE BRITISH}

It would be unprofitable to examine here to what extent this radical operation was justifiable. The reader must pass his own judgment on it. It will be well, however, to remember that the year was not 1900 , but 1755 ; that the perpetrators of it, colonists and British officials, were confronted with what proved one of the most pregnant struggles in modern history, and were ill equipped for it; that they had treated these people with a consistent indulgence that had then no parallel under such circumstances; that the lives and fortunes of 4,000 peaceful English settlers on the Halifax side of the province were in daily jeopardy ; and lastly, that a considerable number of the exiles themselves had their hands red with the blood of Englishmen, not killed in fair fight, but murdered in Indian fashion while peacefully pursuing their daily avocations on British soil.

While the Northern colonies were busy spending blood and treasure in strenuous, if unavailing, efforts to beat back the French, the people of the middle and Southern provinces were in a helpless condition, and engaged in mutual recriminations of the bitterest kind.

At the close of the last chapter we left an Indian war raging along the far-extended and defenceless frontier. The first line of settlement from Pennsylvania to the Carolinas, that of the log cabin and the raw stump-strewn clearing, had been wiped out. The second belt, where the grandsons of its pioneers were living in comfortable houses, surrounded by orchards, meadows, and cornfields, was now a scene of blood and terror, and ringing with the unfamiliar sound of the Indian war-whoop. The third line, 


\section{WASHINGTON AND VIRGINIANS}

that of those old settlements remote from the mountains, and hugging the sea or the tidal rivers, where wealth, education, and political power centred, was, in the meantime, regarding the woes of its compatriots with a philosophy that has earned the trenchant criticism of the historian, and caused a world of anger at the time.

We have seen how Washington, with a thousand raw soldiers, low-class Southern white men, to whom authority was specially odious, was struggling in defence of a frontier nearly four hundred miles in length. Virginia, it should be said, was notoriously touchy on the subject of her boundaries. Her white population at this time was larger than that of the Transvaal Boers to-day, who have placed some forty or fifty thousand men in the field. It was three times that of Natal, who has sent out to war many thousands of her best sons upon no greater provocation. Her frontier counties were swimming in blood and ringing with passionate appeals for succour. It was an occasion, one would have supposed, when the sons of her numerous aristocracy and still more numerous yeomanry would have responded in thousands to the call of their own harried people at least, if not to that of the mother country. They were an outdoor people, bred to the use of horse and gun, and cherished the sort of pride that, without the martial ingredient, seems to lack significance. The existence of slavery made even their time very much their own. The fear of a slave insurrection might influence the numbers available for distant adventure; but one looks in vain among the squires and yeomanry of the Southern colonies for the faintest spark, at this burning period, of the spirit that 


\section{5] ATTITUDE OF PENNSYLVANIA}

one would particularly expect in such a class. The natural fire of youth and love of glory and adventure, to say nothing of patriotic sentiment, that was so conspicuously present with after generations of the same breed, seems in this one to have been almost an unknown quantity. Considerably less than half the officers who commanded the few hundred ill-paid mercenaries that so tortured Washington belonged to the gentry class, and represented their total contribution to the defence of their province, and the long and fierce struggle with France.

A mere handful of Washington's own class are grouped round his youthful and commanding figure in this war. Whatever may have been the virtues of the Southern planter of this generation-and they were not inconsiderable-the love of soldiering and a generous public spirit were assuredly not among them. But the Virginia legislature at least voted money for raising mercenaries, and professed much good intention; while that of Maryland in reluctant fashion followed suit. Pennsylvania, however, as aprovince was much more than apathetic. Her western counties were scourged even yet more cruelly than those of her Southern neighbours, and the cry from the scene of slaughter grew passionate and fierce towards the smug burghers of Philadelphia who held the provincial purse-strings. There were no country gentlemen to speak of in Pennsylvania. Broadly speaking, the main element of the frontier was Scotch Irish, that of the middle counties German, and of the east, with the preponderating city of Philadelphia, Quaker. The latter was opposed to war of any sort on principle, and his secure position 


\section{GERMAN SETTLERS ACTIVE [1755}

made his conscience and his comfort run pleasantly together. The Quakers by numbers and influence controlled the legislature, and to the tales of blood and horror that came pouring in from the borders they replied with homilies and platitudes. Braddock's defeat was a judgment for having interfered with the French! The slaughter of Presbyterian families upon the border, who were replacing the shaggy forests with fields of wheat and corn, was a visitation of God for some assumed bad faith in former days with the Indians! For in the eyes of a Philadelphia Quaker a Presbyterian could do no right, while a red man could scarcely do wrong. To have argued the question with such a man from a logical point of view would have been to argue with a stick or a stone. He was snug in his brick house in the fattest city of all the colonies, and with closed eyes and deprecating, uplifted palms at the bare suggestion of men taking arms in defence of their lives he comes down to us a pretty figure at a time when strong men above all things were so sorely needed. He had his uses and his virtues, but they were not the kind required at the present moment. Some interesting attempts have been made by Philadelphia writers in recent years to defend the action of their Quaker ancestors in this particular, and to upset the verdict of history. They do not strike one as particularly convincing, while the natural partiality that inspires them is obvious.

The German had hitherto backed the Quaker interest in opposing colonial defence. But now the tomahawk had reached the German settlements, and sentiments that were avowedly selfish swung round in an instant at the sight of German scalps. The 


\section{5] PENNSYLVANIA AND THE PENNS}

Pennsylvanians of the west, regardless now of racial cleavages, vowed that if money and arms and men were not voted, they would march on the capital and bring the legislature to its senses by fair means or foul. It is a long story, but the pressure growing irresistible the assembly saw that they might at least enjoy, while yielding, the ever-welcome luxury of quarrelling with their Governor, who was of course a nominee, or agent rather of the Penn family, the proprietors of the province, and at the same time thwarting their persecutors and withholding the relief demanded. So having voted the money, they made the vote conditional on a taxation of the Penn estates. This, they well knew, the Governor had no power to grant, and the Penns could not be heard from under three months. In the meantime the bill would remain unsigned, and the Government be placed in the position of an obstructor. It sounds plausible enough that the Proprietors' estates should be taxed like the rest, but the Penns' lands were in the wilderness, they brought in no income, and had been made unsaleable by the destruction of the frontier before them-a state of matters largely induced by the apathy of the legislature. The latter, too, had stipulated that these lands should be assessed for taxation by their own officials. The Penns' case even in time of peace would seem a strong one when it is further considered that the province owed its very existence to their father; but these were the details for which the colonial legislatures loved to struggle. No other body, however, but that of Pennsylvania would probably have weighed such a trifle against the lives and safety of its people. The Penns in the meantime, 


\section{PENNSYLVANIA AND THE PENNS [1755}

ignorant of the deadlock, had sent out $£ 5,000$ as a voluntary contribution-an amount which, judged by the standard of the time and the war-chest of the province, could give the greatest cavillers no ground for complaint. In course of time, though too late to save hundreds of human lives and an infinity of human suffering, ruin and loss, Western Pennsylvania got relief, but its trials extended far into a period which covered coming events of more immediate import here. 


\section{5-6] THE WINTER IN CANADA}

\section{CHAPTER V}

$\mathrm{N}$ spite of her triumphs both in attack and defence, 1 Canada spent but a miserable winter. The exigencies of war had sadly interfered with the saving of what at the best would have been but an indifferent harvest. Something like a famine prevailed, and the bakers' shops were besieged by hungry crowds. English cruisers watched the mouth of the St. Lawrence with exceeding vigilance, and France, who had frequently been compelled to provide with bread this her colony of agriculturists and hunters on a virgin soil, found it no easy matter to come this winter to her aid.

It was in such emergencies as these, however, that the official clique, who kept a tight grip on Canada, waxed fat. Bigot, who as Intendant had the handling of finances and supplies, was a very prince of Corruptionists, though possessing some good qualities and considerable ability. He had, moreover, raised from obscurity and gathered around him a gang of underlings who had even less breeding and fewer good qualities than himself, were little behind him in wits, and more than his equal in unscrupulousness. That strange medley, the so-called noblesse of Canada, were very easily passed in the race for power by such adventurers. The regimental and staff officers from France represented another element who de- 
spised both classes, but in such banishment were inclined to pocket their prejudices and take such social comfort as was thrown in their way. Out of this mixed material a queer though lively society was evolved at Quebec and Montreal. In spite of French military aristocrats, local titles of nobility, and a haughty Church, official society seems to have been far more Bohemian, less socially exclusive, and much more scandalous than that of New York, Boston, or Williamsburg. But if Canada was short in food and money, the new commander-in-chief, Montcalm, who now arrived with two fresh battalions, was a host in himself, and had a staff that was worthy of him. Let us now, however, turn for a moment to Europe, and see how the nations were grouping themselves for the fiercest struggle of the century, and also what manner of men were those who at this critical moment guided the destinies of England.

These last, indeed, were but an indifferent company, and the state of the country was anything but hopeful. Pitt was still, and destined to be for some time longer, without power. The dead weight of the ridiculous Newcastle, that "hoary jobber," clinging at all costs to office, poisoned the springs of English action in every field, and Pitt's eloquence found congenial and temporary employment in laying bare with withering satire the Premier's contemptible littleness. Through the whole of this winter and spring there were constant alarms of a French invasion. "I want," said Pitt, in a flash of prophetic inspiration, " to call this country out of a condition so enervated that twenty thousand men from France can shake it." But for the present he had to possess his soul in patience, and expend his eloquence on 


\section{5-6] ENGLAND AND FRANCE}

the ill conduct of public affairs. The fleet, however, was numerous and well manned, though bewildered by enigmatic and conflicting orders, which its captains interpreted according to the popular spirit rather than dally over conundrums; seizing French vessels, that is to say, wherever they could find them, and blockading Canada with considerable success. The French, whose policy was changing, at this moment of all others, from an American one of great conceptions to a European one that offered no prospect worth mentioning, were in no hurry to proclaim war with England. Her Government was anxious to accept, not to make, a declaration of hostilities. It professed horror and amazement at the depredations of British ships upon French commerce, and by way of emphasizing these protests released with much ostentation a British vessel that had been brought as a prize into a French port.

France had, in fact, been turned by frivolous counsellors from her lofty transatlantic dreams to a mere conflict of passion and military glory. The leading object of her attack was now to be Frederick of Prussia, against whom that European coalition was forming which plunged the Continent into the horrors of the Seven Years' War. What caused Frederick, with his five million subjects, his small and comparatively poor realm, and above all his formidable army, to be the object of such widespread enmity is sufficiently familiar. He had insulted two potent ladies of indifferent virtue, and robbed a third who was virtuous but justifiably vengeful. This female trio represented France, Russia, and Austria. With respect to the latter, Maria Theresa had a legitimate 


\section{THE EUROPEAN ALLIANCE}

grievance and much reason in her wrath, for Frederick had robbed her of Silesia. Catherine of Russia was stung to fury by his coarse jests at her somewhat notorious weakness for Grenadiers. As for Madame de Pompadour, she had not only been the subject of the Prussian king's continuous raillery, but had been treated by him with personal contumely, and this lady governed both her royal lover and France. An alliance between these three great powers was preparing throughout the winter of 1755-56, and with the addition of Sweden and Saxony, was cemented before the opening of summer, constituting, in the words of Pitt, " the most powerful and malignant confederacy that ever yet has threatened the independence of mankind."

But France, with the certainty of a war with England, had done more than give up the substance of American empire for the shadow of European glory, if indeed glory there could be in a coalition representing ninety million souls against a single province representing five. For she was exposing her very existence in the New World to the gravest risk of complete extinction. To the French champions of the Canadian policy, to the brave men across the Atlantic who were so gallantly inaugurating it, and who divined, or thought they divined, a dazzling future, this turn of the political weathercock must have been bitter indeed; and the more so, seeing the comparative weakness which distinguished at this moment their great rival. That rival's fleet was strong, but her councils and her generals appeared to be contemptible, and her army had been let down to twenty thousand men. Nor could they, nor any one, know that England was in 


\section{5-6] LOST OPPORTUNITIES OF FRANCE}

labour of a leader who was to shake the world to its uttermost limits.

Let us suppose there had been no Pompadour, and that a wholesome monarch, such as indeed was Louis $\mathrm{XV}$. himself in earlier life, aided by clear-sighted ministers, had been ruling France. Can there be a moment's doubt but that she would have turned to face with her whole strength her only real rival? If then she had lavished one-half-nay, one-quarterof the blood and treasure in America that was idly squandered on European battlefields, who dare say in what colours the map of North America would now be painted? The mastery of the seas it is possible no effort on the part of France could have won, but with energy she could certainly have become strong enough to prevent anything like an effective blockade of so vast a line, and could have poured troops and supplies into Quebec, Louisbourg, or New Orleans in sufficient abundance for every practical purpose. Let us be permitted, too, to conceive our neighbours drawing an object-lesson from the prosperity of the British colonies which stared them in the face, and abandoning that religious bigotry which so hampered their own expansion. Let us suppose that France had chosen to do what some of her best Catholic soldiers had so often urged-ceased, that is to say, from treating her Huguenots as ravening wolves, and hounding them from all her borders to become a strength and comfort to her rivals, and given them instead the toleration under their own flag that they had to seek for under others. Can there be any doubt that, in such an event, thousands of the most virile people in France would have sought the shores of French America, and would 


\section{THE FRENCH COURTIERS}

[1755-6

have aided and secured that expansion of dominion which was the one worthy dream of an ignoble epoch? A wise policy, too, could have beyond a doubt attracted to New France, and most certainly to an occupied Ohio Valley, those Catholics of other nationalities who, while they found bare toleration at the best in the British colonies, would have preferred a region where their creed was greeted with a warmer welcome.

But these are idle, if interesting, speculations. Destiny decreed otherwise, and it is not for Britons at any rate to quarrel with her scheme. France spurned the great opportunity of her national life, and, with a folly that to us now seems little short of madness, lavished her resources in attempting to dismember a small country whose defeat would merely serve to strengthen her already powerful allies.

The Pompadour, however, must by no means get the whole of the blame; for the French noblesse, who now swarmed like locusts about the Court and in the army, would probably have shown but slight enthusiasm for the rigours and inglorious hardships of an American campaign. They were ready at all times to fight and to die, but this was a generation to whom fine clothes, fine living, and an artificial atmosphere were necessaries second only to their honour. If fight they must, they would have much preferred to die gloriously after a supper of champagne and truffles, and perhaps under the very eyes of their mistresses, in the trenches of a Flemish town, rather than perish, and their deeds with them, in the trackless forests of America.

So Canada was from henceforth left in a great measure to its own resources, and to such support 


\section{6] WAR FORMALLY DECLARED}

as had been already sent there. The general war in Europe did not break out till August, but in the spring France, turning from all thoughts of a descent on England, made a swoop upon Minorca, which for forty years had been a valued possession of the British. The stubborn defence of Blakeney with under 3,000 men against an immensely superior French force is not so familiar as the failure of Admiral Byng with the English fleet to relieve that gallant officer, and the story of his subsequent execution. The merits of this do not concern us here, but after such glaring hostilities, not in the backwoods of America, but in the full sight of Europe, the farce of peace could no longer in decency be maintained, and war was formally declared against France upon May the eighteenth, 1756.

With all her ill-advised change of policy, France had not wholly neglected Canada. She had sent there one of her very best soldiers, who was to cover himself with glory before he perished in her ruin. For at the very moment when England declared war, Montcalm, with 1,200 men of the admirable regiments of La Sarre and Royal Rousillon, was slowly pushing: his way up towards Quebec, through the drifting icefloes of the St. Lawrence.

Louis Joseph, Marquis de Montcalm-Gozon de Saint-Véran, was a native of the South of France, and proprietor of the hereditary but much-encumbered estate of Candiac, near Nîmes. He was now in his forty-fifth year. He had seen much service on European fields, had been twice severely wounded, and had distinguished himself much oftener. He was the best type of a French gentleman of the eighteenth century, and a type none too common at 
this particular epoch. Unlike most of his kind, when off duty, he was able to bear a rural life with something more than equanimity. He could exist contentedly outside the meretricious sunshine of Versailles, and was never indeed so happy as when settled at Candiac in the midst of his family, for both of which he cherished a most ardent affection.

In his soldierly way he was both cultured and religious; above all, he was brave, honest, and patriotic. For such a man there was certainly not much profit to be looked for in a Canadian command - a matter to which Montcalm with ten children and an encumbered estate could not be indifferent. With equal certainty there was much hardship in prospect, and no great likelihood of a successful termination to the struggle. Montcalm's private letters, cheery though they are, show how little he appreciated his long banishment from home and friends and country, and indicate pretty plainly how patriotic were his motives and how admirable his principles. With him went De Levis and De Bourlamaque as second and third in command, both excellent soldiers; while his aide-de-camp was Bougainville, the diarist of these campaigns, and the famous traveller of later years.

The Governor of Canada in the meantime, with all the typical vanity of that Canadian nationality he so greatly affected, would gladly have dispensed with professional assistance and himself conducted the military as well as the civil affairs of the colony. De Vaudreuil's hints to the home Government, however, as to the advantages of such an arrangement were thrown away, and he had to 


\section{6] FEEBLE CONDITION OF OSWEGO}

put the best face he could on the situation, which, to judge by Montcalm's letters, who as yet knew nothing of these heart-burnings, was a very good one. The general, to be sure, was nominally under the Governor's orders; but it is not difficult to estimate what force these would have in the stress of a fight for existence. A civilian, it will be remembered, was also in command of the British American forces at this moment. But there, on the contrary, it was by no means certain the coming change was for the better. Shirley was not a heaven-born general, but there were many people of good judgment who thought that he was at any rate better than his immediate successors. He had sense, energy, and some gift for procuring and adopting the best advice; he also knew the country and the people. His recent failure against Niagara was entirely venial; but he was loudly blamed later on for not having properly victualled the garrison he had left to winter at Oswego. The omission had caused great sickness and suffering. The sentries, so credible witnesses declared, were so weak from want of food that they had to go on duty with a stick to keep themselves from falling, while the mortality was considerable. The rumours of Shirley's supercession which were rife throughout the winter were officially confirmed in February. He put aside, however, the mortification which vexed his soul most deeply, and worked with zeal and honesty in preparations for the coming season.

It is bardly necessary to remark that campaigning on any serious scale was out of the question in the Northern colonies till the woods and lakes had been loosed from their wintry burden by the warm winds 


\section{NEW ENGLAND'S ENERGY}

of April, and wholly freed from it by the suns of May. Even armies in Europe at that day went into winter quarters, and suspended operations by a sort of unwritten agreement, as if war were in truth a game to be played under conventional rules. But the colonial forces, after leaving slender garrisons in a few isolated snow-bound outposts, not only went into winter quarters, but to their homeseach man to his farm, his office, or his shop. He ceased to be a soldier, and it rested entirely with himself whether he ever would be again. With the exception of a few permanent companies, the colonies had every year to form practically a fresh army, and that under difficulties which were very great, though in part of their own making. That troops would be required, and in greater numbers than ever before, for the season of 1756, was now very evident. New England, the chief source of supply, had been much discouraged, partly by the military failures of the preceding year and partly by the large debt its outlay had accumulated. Though full of zeal in her stolid, undemonstrative fashion, it was with profound satisfaction that, as an eminently business-like people, she heard of the substantial sum of $£ 115,000$ voted her by the British Parliament for past expenses, and, greatly cheered, girded up her loins for a renewal of the contest.

Shirley was in a strange position. He had to plan the campaigns for the coming season, and trust to their meeting with the approval of his successors, who seemed in no hurry to take up their responsibilities. There was in truth no wide field of choice. The two nations, as I have before remarked, could only strike each other by land in serious fashion 


\section{6] OPERATIONS FOR THE NEW YEAR}

on the two lines ${ }^{1}$ with which my readers are, I trust, now familiar. Oswego, the extremity of the western route, and no longer a mere base for an attack on Niagara, called loudly for support, and was in fact in imminent danger. On the northern route the French held Crown Point and Ticonderoga, being thus omnipotent on Lake Champlain, while the British, forty miles to the southward, had their outposts at the head of Lake George. It was the obvious object of each to drive the other back-the one on Albany, with a possibility of capturing it ; the other on Montreal, with about the same prospect of success. The French, however, of the two, would be more strictly on the defensive. Whatever their hopes of Western'dominion, they had no serious thoughts of doing more than temporary damage to the old British colonies, while the English, in view of their numerical superiority, could fairly regard the conquest of Canada as a possibility. A second expedition to Duquesne was of course an inevitable move, both to avenge Braddock and to destroy the hornets' nest that was ravaging the frontiers of Pennsylvania and Virginia. But without the help of these two provinces the venture was impossible; and, as we have seen, they were scarcely able at this moment to protect themselves.

The Earl of Loudon had been appointed to succeed Shirley, but he did not arrive till August, and in the interval General Abercrombie, with Colonel Webb as second in command, acted as substitute. These two officers landed in June, and, with their tardy chief,

1 The route to Fort Duquesne, or the third line of attack, was of course the very reverse of a natural artery, and only necessitated by temporary conditions. 


\section{A COLONIAL MUSTER}

constituted perhaps the most indifferent trio that were ever inflicted at one blow upon a British army. Poor Shirley got little thanks either from his successors or the home Government for his faithful and unquestionably useful services. He had, moreover, lost two sons in the recent campaigns.

It was always a cumbersome business getting the New England troops into the field, not on account of lack of zeal, but of the jealousies which would not tolerate any central system of organization. Each colony insisted on retaining in its own hands the transport and maintenance of its forces, and each watched its neighbours narrowly, lest their burden of labour and war contribution should be proportionately less than its own. Usually, too, they strictly limited the sphere on which their troops were to act. Their method of raising an army, after the legislature had voted the money, was in the first instance to call for volunteers. If this did not produce the fully required result, the colonels of militia were instructed to muster their regiments, and draft out of them the number of men still needed. Most brought their own firearms; those who did not were supplied with them, in addition to hats, uniforms of blue cloth, knapsacks, powder horns, and canteens. This year each man received a bounty of six dollars on enlistment, and, as a private, twenty-six shillings a month as pay. In addition to their rations, a gill of rum was served out daily; while, if they misbehaved themselves, republicans in habit of life though they were, handcuffs and the wooden horse, and even the whipping post, were the manner of their punishment. This division of authority caused much confusion and no little ill temper among the heads 
of the army. "I wish to God," wrote Loudon to Winslow, "you could make your people go all one way"; while a poor commissary of provincial troops complains that all the thanks he gets for his endeavours to supply them is to be called a $d-d$ rascal.

Albany and the neighbouring banks of the Hudson formed now, as ever, the point of concentration for all the Northern forces, both those destined for Lake George and those intended for Oswego. The first were to be nearly all New England troops, and by slow degrees some seven thousand men were gathered in two large camps, or near them-the one at Fort William Henry, on Lake George, the scene of Dieskau's repulse; the other at Fort Edward, fourteen miles nearer Albany, on the Hudson. The first was commanded by our old friend Winslow, the provincial officer of Acadian celebrity now ranking as a general; the second under that still more capable New England colonel, Lyman, who, it may be remembered, supported Johnson at the same place in the previous year. Here the troops waited for Loudon, and suffered all the evils and discomforts inevitable to a mob of amateur soldiers, indifferently provided for and left for a prolonged period of comparative inactivity in a wilderness. Of occupation of sorts there was enough in strengthening the fortifications, clearing the forest around them, improving the fourteen miles of road over the portage, and building the large fleet of whale-boats and batteaux which would be required for conveying the army down the lake to Ticonderoga.

The fighting was confined on both sides to small scouting and scalping parties, who vied with each 


\section{LOUDON ARRIVES}

other in deeds of daring and endurance, and supped their fill of the horrors of Indian warfare, and la petite guerre. The bulk of the troops, ignorant of the first principles of camp sanitation, sickened by thousands, and died literally by hundreds, in a region of itself notoriously healthy. Their officers, in the absence of more stirring work, found all too much time for airing those jealousies inevitable to an illdisciplined force composed of the soldiers of four or five different Governments. The godly chaplains of New England, who had accompanied their flocks to the field, bewailed their backslidings when freed from the eye of the village minister and the village deacon. Their rousing sermons were often but ill attended, and not at all, they complain, by the senior officers, who drank punch and smoked in their tents, not only during the hours of divine service, but actually in sight of the open-air congregation. The rank and file, if they could not escape the preacher's regular exhortations, took to cursing and swearing as kindly as if they had been born in Wapping, or had served in Flanders !

When, in August, Loudon at length reached Albany, he found himself seriously embarrassed by one of those amazing blunders to which British Governments, in dealing with colonials, have in former days been so prone, and perhaps are not yet wholly cured of. A special order had come out from England that no provincial officer, under any circumstances, should rank higher than a senior captain of regulars. In other words, a British major of one-and-twenty, who had never seen a shot fired-and there were plenty such in the army of that day-would take precedence in the field of a provincial brigadier or 


\section{6] BRITISH AND COLONIAL SOLDIER}

colonel, of veterans like Winslow and Lyman, for instance; of Johnson, Bradstreet, or George Washington! The colonial officers were ablaze with indignation, as well they may have been. Loudon, who was himself a wooden kind of man, and had certainly no tenderness for provincials, was greatly exasperated. There was no question of rescinding the order, no hope of compromise, nor authority to grant it. The officers of New England regiments threatened to go home in a body. Loudon appealed to Winslow, who was a broad-minded, sensible man, to use his influence ; and he brought his people to see that there was nothing for it at present but to swallow the uncalled-for and ill-timed slight. Fortunately, no movements of importance took place to test the strain; but the sore rankled. British officers of that day were only too prone, by their supercilious attitude, to wound the susceptibilities of their colonial brothers in arms. It is, of course, only the old story of the professional and the volunteer added to that of the Briton and the colonial, which no one who has lived in British colonies would require to have elaborated. This sore feeling was a conspicuous feature of the war. It is well known to have been one of the irritants that prepared the soil for the Revolution. One would be inclined to think that it was peculiarly an English failing; but, as a matter of fact, something very like it prevailed in Montcalm's army. But this special order was another thing altogether. It was not a mere question of tact or manners, but a blunder of the worst kind.

It was issued at a critical moment in face of the enemy, and would have delayed, if not hampered, Loudon's attack; but Loudon would in no case 


\section{A FUTILE CAMPAIGN}

probably have now attacked. Nearly six thousand French were at Ticonderoga, at the near end of Lake Champlain, strongly entrenched. Twice their number could not have moved them, and Loudon, though by the close of summer he had 10,000 men under his command, including the sick and the 35th regiment (Otway's), which had just come out, 900 strong, considered that the effort was hopeless. Rumours of a French attack from time to time came drifting up the long, narrow waters of Lake George; but the French, strong for defence, could no more attack Loudon than he could attack them. Thus the summer passed away in costly inactivity, and when the ice spread once more over lake and stream, when the green mountains of Vermont were no longer green, and the Adirondacks showed a snowy carpet beneath their naked woodlands, French and English were both more firmly lodged than in the previous year, but neither were one whit more forward.

Loudon was a melancholy and irascible man. He was in no sense fitted for his position, but he can hardly be held responsible for the barrenness of the season's campaigns on Lake George, unless, indeed, his late arrival in America may be held against him. He would have enough to answer for in the following year, though his blunders, unlike those of his brother generals, were to be those rather of omission than of misguided action.

In the early part of this year a royal commission had been sent out to Sir William Johnson, appointing him colonel and sole superintendent of the Six Nation Indians and responsible to the Crown alone. Colonial dealings with these Indians, chiefly carried 152 


\section{6] JOHNSON PACIFIES THE INDIANS}

on by the Dutch traders of Albany and New York, had worked incalculable mischief. The French were striving more vigorously than ever, by bribes and threats, to win over the Six Nations, and the latter, growing more disheartened as English prestige declined, were now in a dangerous state of hesitation. Matters were indeed so serious that Johnson made a perilous journey through forests, alive with French and Indian freebooters, to the Six Nation capital at Onandaga, and after a fortnight of that sensational diplomacy he understood so well, he had secured at any rate their neutrality. He raised his voice, too, further afield, and tried to stem the raiding hordes of Delawares and Shewanoes, who were still desolating the frontiers of the middle colonies. Some of these actually came at his summons all the way to Fort Johnson, where, amid great ceremonies, much din of war-cries and riotous dancing, and floods of rum, he exacted promises from them which possibly a few kept. But these nations, save those small broken bands which had already joined the French, were secured to neutrality, and this, from their midway situation between the rival armies, was a point of immeasurable importance.

While nothing of moment was achieved this season by either side at the principal seat of war, a disaster befell the British arms to the westward, as great as that of Braddock's defeat in the preceding year. This was the fall and destruction of Oswego, whose garrison has been already alluded to as weak in numbers and half starved. The route thither from Albany was guarded at certain spots by rude forts. One of these had been attacked and destroyed by a flying column of French and Indians in the dead 


\section{BRADSTREET TAKES SUPPLIES 「1756}

of winter. Shirley, conscious of Oswego's weakness but short of troops, had in the early spring struck out a new departure and engaged two thousand boatmen and whaling hands from the coast to carry supplies to the Ontario fort, arming them with guns and tomahawks. Bradstreet, another colonial colonel of sense, zeal, and daring, and some military experience, was placed in command. The outward journey, up the Mohawk and its feeders, with a portage across the watershed and thence down into Oneida Lake and the Oswego River, was achieved without opposition. On the return journey, however, Bradstreet, whose force was in three divisions, was stoutly attacked about nine miles up from Oswego by seven hundred of the enemy. After a smart encounter in and around the bed of the Oswego River, his boatmen drove the French back, with a loss of about fifty on either side. This, however, was but an incident barren of any results but the actual lives lost. The French had intended to strike Bradstreet laden with supplies on the way up; but he had been too quick for them: indeed, this officer had an excellent habit of being too nimble, both in attack and defence, even for his nimble foe. There were few of his compatriots, British or colonial, at this time of whom such could be said.

Almost before he was missed, Montcalm had slipped away from Ticonderoga and arrived with a powerful force in front of the dismayed invalids and feeble, ill-protected garrison of Oswego. । De Vaudreuil and Montcalm did not often agree in a plan of campaign ; but they were in full accord as to this one. De Villiers, who had led the attack on Bradstreet, was still within reach, so was Rigaud, the Governor's 


\section{6] WEAK CONDITION OF OSWEGO}

brother, who had gone westward with more men. It was early in August when Montcalm, leaving De Levis in command at Ticonderoga, started at full speed for Fort Frontenac, reaching there in a week. Frontenac lay just across the lake from Oswego, and about sixty miles distant. The regiments of La Sarre and Guienne had in the meantime been forwarded there from Montreal, and that of Béarn fetched up from Niagara. Besides these, Montcalm had with him Canadians, colony regulars, and Indians, amounting in all to about three thousand men, with a strong train of artillery, including some of Braddock's captured guns. Oswego, a considerable tradingstation, with houses, storing sheds and forts, a mere gash in the interminable forests that in those days brooded over the now populous and busy shores of Lake Ontario, was entirely unconscious of its impending fate. It possessed two very inferior forts standing upon either side of the mouth of the Oswego River, and a third one behind, which is described as merely an improved cattle pen, derisively christened "Fort Rascal." None of them, however, were fit to stand cannon shot. Mackellar, the chief British engineer in America, had condemned the place entirely. Why nothing had been done to strengthen it is not explained.

* Colonel Mercer, an excellent and brave officer, had been left, it will be remembered, in command, and had with him about a thousand soldiers of sorts and eight small guns. There were also some six hundred non-combatants, including a hundred and twenty women and children. The soldiers were chiefly of Pepperall's regiment (51st) and New Jersey militia, and were in great part recruits or invalids 


\section{MONTCALM BESIEGES OSWEGO [1756}

Montcalm crossed the extreme eastern end of Lake Ontario on the nights of the fourth and fifth, by divisions. On the eighth all his force was collected on the southern shore. Thence it took them about thirty hours, part of the army marching through the woods, part skirting the shore in batteaux, to reach a point within a mile of Oswego. It was not till the French were all gathered here on the shore, with guns ready for action, that the garrison knew any movemert was impending, so bad was their scouting. Montcalm's chief engineer went forward to report, accompanied by clouds of Canadian and Indian sharpshooters, who accidentally shot him, though not till he had pronounced the forts to be untenable. Montcalm then set about cutting his intrenchments, knowing full well that he had the place in the hollow of his hand. The garrison fired their light guns at his working-parties, but with little effect. The French were upon the east bank of the river, and Fort Ontario, which protected that side, was laid out in the shape of a star, and built of tree-trunks flattened upon both sides and placed upright in the ground-an excellent defence against musketry, but none whatever against cannon. Three hundred and seventy men of Pepperall's regiment were inside it, but Mercer, who was in the fort west of the river, signalled to them to evacuate it and cross to his side. This move was effected without interruption. In the night Montcalm had thirty guns mounted on the river bank within five hundred yards of Mercer's fort. This was only protected against the south and west, the river side being entirely open. The gap was filled by pork-barrels for want of something better, and Mercer, thus equipped, pre- 


\section{6] THE FALL OF OSWEGO}

pared for the attack by opening the hottest fire he was capable of upon the French. Some execution was done; but when the heavy cannon of the enemy, hurling grape and round shot through the flimsy defences, got seriously to work, the hopelessness of the defence became very evident, though Mercer behaved with great bravery. Montcalm now decided to attack the further side of the station, which was weakly intrenched, with infantry. There was a ford over the Oswego River two miles up, and a large force of Canadians and Indians crossed it and swarmed around the ramparts, pouring in a heavy fire from the shelter of the woods. Mercer was at this moment killed by a round shot, and with his fall the heart went out of the garrison. Their case was indeed hopeless; the non-combatants clamoured loudly for surrender, and the shrieks of the terrified women, as the grape-shot from Montcalm's guns shivered the wooden buildings and defences in all directions, emphasized the demand. The frightful yells of the Indians, too, outside the walls was significant of the ghastly terrors of an assault. A council of war was called, and it was decided to capitulate. The surrender was practically unconditional. One thousand six hundred and forty prisoners were taken in all, most of whom were forwarded to Canada. Six vessels carrying fifty-two guns fell into Montcalm's hands, with two hundred barges, a hundred and thirteen cannon and mortars, with large supplies of ammunition, pork, flour, spirits, silver, and $£ 18,000$ in cash. Five standards were captured and hung as trophies upon the walls of Montreal Cathedral. The usual difficulty was experienced in restraining the Indians from taking what 


\section{DESTRUCTION OF THE POST}

seemed to them their natural toll of blood, plunder and scalps-above all, when liquor was plentiful, as it was on this occasion. A bloody scene at one time threatened, and all Montcalm's efforts united to those of his French officers were needed to prevent it. The Canadians, of all ranks, were neutrals on this subject. They well knew the risk of losing their allies if they thwarted them in the matter, and had themselves grown callous to its horrors, regarding the murdering, scalping, and torturing of prisoners at the hands of the savages with considerable equanimity. There is some little discrepancy in the accounts of what happened at the fall of Oswego. It seems probable, however, that only prisoners who tried to escape through the woods were tomahawked-a fate which they courted with their eyes open. Montcalm, however, reports that it cost him a good deal of money to redeem prisoners from the Indians. The casualties on either side in the siege were inconsiderable; but the loss of a station so vital to the British was extremely serious.

Montcalm now took steps to wipe Oswego off the face of the earth. He destroyed all the vessels and stores he could not carry away, and levelled the buildings and fortifications with the ground. Among the ruins and ashes his senior priest, Piquet, planted a tall cross bearing the inscription, In hoc signo vincunt. From a pole near by were hung the arms of France, engraven with the words Manibus dat lilia plenis. The spot was then abandoned to the wolves, and Montcalm, with his army, his prisoners, and his booty, sailed away eastward.

Webb had all this time been toiling up the Mohawk 158 


\section{$1756]$}

\section{WEBB'S BLUNDERS}

from Albany, and was rather more than half-way through when the news reached him that Oswego had fallen. As he appears to have only had with him that remnant of the 44th regiment which had survived Braddock's defeat of the previous year, it is perhaps just as well that he did not make a present of another three or four hundred prisoners to Montcalm. It was hardly Webb's fault that his support was so tardy as well as weak, but when scouts brought him news of the capitulation, he justified in his person and by his action the soreness that was felt at the wholesale snubbing of provincial officers. Fresh rumours asserted that Montcalm was coming down the western route to Albany with six thousand men. Webb waspanic-stricken. He did not pause to ascertain whether the rumours were true or whether Montcalm could get such a force through such a route; but he acted as if the whole French army were upon him. He burnt two forts that had lately been erected at considerable trouble, and he filled thechannel of Wood Creek ${ }^{1}$ with fallen timber, of which it had recently and at great labour been cleared for purposes of navigation. He then hurried back to the German flats upon the Mohawk, and sat down to realize in due course that his performance was one that no militia subaltern of average wits would have committed. It was a conspicuous instance of the fatal errors into which a trained officer of only moderate capacity may fall through sheer ignorance of a country, its people, its geography, and its mode of warfare, when coupled with a proper contempt for local advice.

1 Not of course the Wood Creek near Lake George. 


\section{A Disastrous BLOW}

The destruction of Oswego was in some ways more disastrous, though less dramatic, than Braddock's defeat, and another wave of shame and sorrow swept over the British colonies. Niagara was now secure against all attack. Worse still, British influence had been swept from the shores of Ontario, which was once again a French lake. Worse than all, perhaps, another deadly blow was struck at what was left of British prestige. Save in the New England provinces, there was no spark of military vigour. No answering challenge to the audacity of the French came from the middle and Southern colonies; the minimum of necessary protection seems to have been the limit of their ardour. The small bodies of mercenaries or militia they sent into the field, and the handful of individuals from the prosperous classes, that showed what we should now call a proper spirit, only seem to accentuate the lethargy. It was quite evident that if Great Britain was to maintain her position in America she must make the effort herself, and as yet she seemed to be in no good condition for such enterprises. France, on the other hand, seemed surely blind to her good fortune. The moment was hers in America; but she was turning her back on it, and gathering her strength and treasure to waste in that bloody orgie which was soon to engulph continental Europe. 


\section{6] NEWCASTLE'S RESIGNATION}

\section{CHAPTER VI}

URING the past autumn the dead weight of from British policy. His very friends could no longer be either bribed or flattered into his service, so with a groan of anguish like that of a miser parting with his hoard, the venerable intriguer and pettiest of Prime Ministers at last resigned. But it was no easy matter at that moment to form a fresh Ministry. The personal likes and dislikes of the king, his natural attachment to Hanover, and the mutual antipathies of potential ministers made a strong Government impossible, and even a compromise most difficult. Pitt was already recognised as not only the most popular but as the most brilliant of the group. But Pitt was most unacceptable to the king, whose knowledge of English was anything but profound, while his love of brevity in the discussion of business was notorious, and the Great Commoner had a habit of treating him in his closet to flights of oratory which were not only unintelligible to his Majesty but insupportable to his practical, drill-sergeant type of mind. Lord Temple was another unwelcome counsellor. His civility the king found only less offensive than his remonstrances, which at times he declared took the form of downright insolence. 


\section{THE KING AND HIS MINISTERS [1756}

The Byng trial was now dividing England into two camps, and Temple, in his endeavours to soften the king's heart towards the unfortunate admiral, drew a parallel between his conduct and that of his Majesty's at Oudenarde, somewhat to the advantage of Byng. In short, he allowed the king to assume that if Byng deserved to be shot, he himself had deserved to be hung! A Ministry, however, was at length formed, and Parliament met in December. The Duke of Devonshire, a man without talent, but of conspicuous honesty, became Prime Minister, with Pitt as Secretary of State. The speech from the throne was so ludicrously alien to the king's wellknown sentiments, that the humour of it found expression in one of those quaint and cynical growls in which the second George was at times extremely happy.

A printer had been arrested, and was waiting trial for issuing a spurious account of the royal speech. "I hope they will deal leniently with the poor fellow," remarked the king, "for I have myself read both my speeches, and so far as I understand either, I prefer the spurious one." A national militia on a new footing was to be formed, and Hanoverian troops who had been quartered throughout the summer at Maidstone and Winchester, conducting themselves at both camps in exemplary fashion, were to be sent back. The first measure was notoriously unpalatable to the king; the second was accompanied by circumstances evidently calculated to wound his feelings. Pitt was laid up with the gout for most of the session. Still, when they did meet, his well-known opposition to a Hanover policy, his uncompromising independence and mas- 


\section{7] THE FIGHT WITH FRANCE}

terful nature, made him most distasteful to the king so long accustomed to Newcastle's silken and deferential manners. There seemed no alternative, however, but to endure it, as a dismissal of the newmade Government on such grounds would have been venturesome just then for a Hanoverian king. But the Duke of Cumberland also hated Pitt for his dislike to Hanover, and the duke was at that moment starting to take command of the Hanoverian army, in view of a French invasion. Not relishing the prospect of being liable to Pitt's control, he worked on the inclinations of his father and succeeded in screwing his courage up to the point necessary for a dismissal of the objectionable ministers. The fashion in which this was done hardly belongs to our story. It will be sufficient to say that by April the country was again without leaders at a critical moment and in time of war. For three months this hazardous state of things continued, so impossible was it to form a ministry that would also please the king who prayed continuously to be delivered from Pitt, the man for whom the cry of the country was getting louder and louder. The best that could be said for the hiatus was that it was at least preferable to Newcastle's activity. That irrepressible jobber, pining for so many months in the unwonted shades of opposition, was again hungering for power. Devoid of either sensitiveness or humour, and impervious to the contempt of the country, he cherished hopes of yet once more steering the ship of State with a subservient and docile crew. The difficulty of securing combination among the abler men, and the enormous parliamentary and corrupt influence 


\section{PITT IN SUPREME POWER}

of the duke, brought him within measurable distance of inflicting himself, and with himself disaster, upon the country. The king vastly preferred his yielding, timorous manners to the uncompromising independence of Pitt or Fox or Temple. But Newcastle, with all his hopelessness in great affairs, was matchless at intrigue, and possessed an extraordinary power of reducing numbers of otherwise respectable politicians to something like political slavery. Even the king lost patience when some person of eminence rejected his offer of preferment till he should learn the pleasure of the ducal wire-puller. "They would sooner," he snapped out, "be the Duke of Newcastle's footmen than serve me."

The result of this lengthy and precarious confusion was the rise of Pitt to supreme power, a power so gloriously used as to make the epoch marked by it one of the most memorable in the annals of Britain. A notable feature, too, of the moment was the partnership of Newcastle with the man who had so mercilessly lashed him and so utterly despised him. Nothing but the greatness of the one and the insignificance of the other made such a combination possible. So Newcastle returned to office, but on the sole condition of abjuring all connection with great affairs, and of confining himself wholly to the dirty work of politics, which he loved, and which possessed at that time an importance not very easy nowadays to fully realize. Pitt had now a free hand, but when that happy consummation was reached it was past midsummer and he could exercise but little influence on the year's operations which had been already planned. He had succeeded, however, 


\section{7] REINFORCEMENTS FOR AMERICA}

in the face of some opposition, in raising the first of those Highland regiments which from that day to this have been such a conspicuous feature in our line of battle. Fifty-two thousand men had been voted in the recent Session of Parliament for the Army, and forty-five thousand for the Navy, while the militia had not been neglected. Eight thousand men were ordered to reinforce Loudon in America, and, adopting that general's very dubious advice, Louisbourg, with Quebec to follow in the event of success, was made the somewhat premature object of the main attack. It was an ill fate for France that the moment which saw the advent of Pitt to power in the councils of Britain almost coincided with the withdrawal from her own of the men who had been the chief support of her Canadian policy. Such forces as she had thrown into Canada were of excellent quality, and in Montcalm at least she possessed by very far the ablest soldier on the American continent at that time, while in her colonists she had a willing and efficient militia. Through the past winter of 1756-57, little could be ascertained in Canada about the intentions of the British. The bare rumour of a threatened attack on Quebec would cramp Montcalm's movements and prevent him from fully concentrating his strength in an attack on Albany and the flourishing settlements of the Hudson. The slowness and uncertainty of news in those days is hard to realize, and Quebec particularly, seated on its throne of snow and cut off from the Atlantic by endless leagues of ice and vast areas of frozen forests, awaited each recurring spring, in a state of more or less uncertainty, what fate might be in store 


\section{VAUDREUIL AND MONTCALM}

for it at the bursting of the leaf. Vaudreuil wrote to his Government upon every opportunity long letters in praise of himself and his Canadians, and in depreciation of Montcalm and his regulars. Montcalm also wrote home, touching with good-natured contempt on Vaudreuil as an amiable man without a will of his own, and the victim of designing creatures. He speaks of the Canadians as useful behind breastworks or in the woods, but of no account for a front attack. Like every other European visitor of that day, he remarks on their inordinate vanity and boastfulness, "believing themselves to be the first nation on earth."

Vaudreuil confides to the French minister that one Canadian is worth three soldiers from old France, though the latter, he condescends to admit, are good in their way, and it is significant he presses for more of them! His figures, when applied to the facts of a campaign, might almost be reversed without being very wide of the truth. He had a tolerably consistent plan of multiplying the enemy in every engagement by two, and their losses by three or four. Montcalm's victories, too, were all due to Vaudreuil's initiative and support; his reverses to neglect of Vaudreuil's advice. By this time, however, the French Government had probably begun to pigeon-hole the voluminous documents that emanated from Quebec. The Governor's childish vanity and hopeless inability to speak the truth did little harm. He had his uses, being amazingly energetic and really patriotic, while extolling everything Canadian at the expense of France was perhaps just now a fault on the right side. When it came to severe fighting, however, Montcalm generally 
took his own line, and it signified very little if the Governor filled sheets of paper claiming the credit of it, if credit were earned, to a remote Minister of Marine, who probably never broke the seal. If Montcalm had a fault, it was perhaps his temper, which seems to have been quick. Like Braddock, he, no doubt, had infinite provocation.

But the silence of this winter on Lake George was not to be broken only. by the howling of wolves in the Adirondack Mountains and the roar of falling trees in the snow-laden forests. The outposts who guarded the temporary frontier of the two nations at Ticonderoga and Fort William Henry respectively, amused themselves from time to time, and not unprofitably, in scouting for prisoners, whose information was highly prized, and failing this for scalps. One really serious attempt on the British fort was made in March. It seems to have been designed by Vaudreuil, and was placed, moreover, under command of his brother Rigaud, which sufficiently accounted in the eyes of the old French party for its comparative failure. Nor did he trust to the few hundred men who were wintering at the front for his enterprise, but pushed forward from Montreal a force that raised the attacking party to 1,600 men-regulars, Redskins, and Canadians. They stayed some time at Ticonderoga making scaling ladders, and with these upon their shoulders they traversed the lake on the ice and crept close to the British fort on the night of March the eighteenth, to the entire surprise of the garrison. Major Eyre was in command with less than four hundred effective men. The British garrisons in all these cheerless wintry stations made the most of anniversaries. Major Knox, in his day-to167 


\section{REPULSE ON LAKE GEORGE}

day journal of dreary banishment among the Acadian forests, gives amusing accounts of the strenuous efforts at festivals which the feasts of St. George St. Andrew, and St. Patrick, to say nothing of birthdays, called forth among the soldiers. At Fort William Henry the Irish saint had been done full justice to the day before in copious libations of rum, and the gallant colonial rangers having as yet no Fourth of July to their credit, patronized indiscriminately the festal days of their British brothers in arms.

The French were just a day too late to gain what advantage might have accrued from any laxity after such festivities, and were received in the darkness by a shower of grape and roundshot from the garrison, who had heard the sounds of their approach while yet upon the ice. Vaudreuil had not only given his brother the command, but had put his notorious predilections into practice and pinned his faith on his favourite Canadians and Indians. Admirable in defence and in the woods, they now showed their incapacity for a front attack on ramparts manned by determined men. Two hundred and seventyfour regulars of the 44th regiment and 72 rangers kept this force of 1,600 men at bay for five days. They were offered lenient terms of surrender, and at the same time virtually assured of massacre by the Indians in the event of refusal. But these gallant men, though neither well found nor very well protected, refused the overture with scorn. It is significant, too, that these soldiers were the remains of one of Braddock's broken regiments, while the most active of Rigaud's officers in attack was Dumas, the hero of that fatal field. This time the 
tables were turned, and the French many fell back repulsed before the British few, not however before they had succeeded in burning the detached out-buildings round the fort and a considerable number of sloops, batteaux, and whale-boats that lay ready or in course of construction for the operations of the coming season. On March 24th the whole French force disappeared down the lake amid a blinding snowstorm, having cost their Government fifty thousand livres, and inflicted a loss equal to perhaps a tenth of that amount. Eyre and his brave garrison marched out with their numerous sick a few days later, and were duly replaced by five companies of the $35 \mathrm{th}$, under Monroe, whose name is indelibly associated with the more memorable events that in the coming summer made the spot famous in history for all time to come.

It was in this same month of March, 1757, that the gallant Knox commenced, as a lieutenant, that invaluable journal which he closed four years later as a major at the fall of Montreal. He was now at Athenry in charge of a detachment of the 43rd regiment, whose headquarters were in Galway. They were ordered to Cork, as part of the force of 8,000 men which Parliament had recently voted for Loudon's support. Six other regiments from various Irish stations were gathering at the western seaport, namely, the second battalion of the 1st Royals, a thousand strong, together with the 17th, 27th, 28th, $46 \mathrm{th}$, and the $55 \mathrm{th}$, each mustering some seven hundred effective men. By the end of March they were all collected, and lay awaiting the fleet from England that was to convey them to America, their actual destination-namely, Halifax-being not yet 


\section{CORK HOSPITALITY.}

made known. Cork, at the present day, does not suggest itself as the port most likely to treat an Imperial armament destined for foreign service with special enthusiasm or an excess of practical sympathy, But Knox, who was a Scotsman, cannot express sufficient admiration for its attitude during the six or seven weeks in which the city swarmed with soldiers and sailors. It was one of cordial good will and generous effort. There were neither the riots nor brawls common in his experience to the influx of a large force into a big town. Instead of raising the price of necessaries and lodgings on the poor soldier, under such great demand, as was the common custom, the citizens gave him of their best at the lowest prices, while large subscriptions were raised for the support of the women and children he left behind him. One is accustomed to think a somewhat brutal indifference in matters of this sort was characteristic of the Hogarthian period, and Knox's account of Cork at a trying period is pleasant reading. There were no meetings, such as we now see, to vote success to the scalping knives of the Shewanoes and Pottawattamies. Even if the blessings of free speech had been then sufficiently developed, the native sense of humour was still too strong to have tolerated in the alderman of the day such doleful exhibitions of clumsy malice. Sympathy with France, as a Catholic power, and indeed, for more solid reasons, might reasonably have been looked for in Cork at such a time, but Knox at least tells us of no such discordant notes. On April 25th the expected fleet of warships and transports appeared off the Old Head of Kinsale, and on the following 


\section{7] BRITISH EXPEDITION SAILS}

day anchored in Cork Harbour. There were fifteen battleships carrying nearly a thousand guns, and fifty transports, averaging some two hundred and fifty tons apiece, for conveying the troops, besides numerous other craft laden with stores, siege guns, and ammunition. It may be worth noting too, that a hospital ship of five hundred tons accompanied the fleet. The force embarked was in all something under six thousand men.

It required about six transports to carry a regiment, giving, therefore, something over a hundred men, besides officers and a few women and children, to every vessel, while each one carried a pennon to distinguish the regiment it was helping to convey. The Admiral in command was Holborne, with Commodore Holmes as second. The long delay in reaching Cork had been caused by adverse winds, and it was this, in great part, and not mere official dilatoriness, as is sometimes said, that proved the eventual failure of the enterprise. French fleets, it is true, had got out promptly and were already across. But they were unhampered by convoys, nor does it follow that the conditions of sailing from the Bay of Biscay were always suitable to getting out of the Solent.

It was the eighth of May when the British fleet, numbering upwards of a hundred ships, with their white sails filled by a favouring wind, swarmed out into the open sea. Here three more battleships and a frigate put in an appearance, owing to a report that a large French fleet intended to intercept Holborne, and there was good ground for the rumour.

Knox gives us a vivid picture of life on one of these 


\section{TRANSPORT OF THE OLDEN TIME [1757}

small transports a hundred and fifty years ago. They soon experienced bad weather, and their ship was separated from the fleet more than once, though they succeeded in finding it again. When a fortnight out, however, they lost it altogether, and were left henceforward to their own devices. What those of the skipper were likely to be soon became unmistakable. Indeed, Knox and his companions had shrewd suspicions that, if this worthy mariner had not actually contrived their isolation, he was in no way depressed by it. On their urgent demands and with some reluctance he opened his secret orders, which proved Halifax to be their destination, as was generally suspected. The course he proceeded to steer, however, struck even infantry officers as having a strangely southern bias about it for the coast of Nova Scotia. It was more than suspected that he had letters of marque, for privateering was just then immensely profitable. The skipper's cabin, too, bristled with cutlasses and firearms; the ship mounted seven guns, and with a force of a hundred soldiers besides his crew on board, the temptation to get into the track of merchant vessels and engage in a little profitable diversion seems to have proved altogether too strong.

They sighted several ships, and each time the decks were cleared for action, but in every case a closer inspection proved the hoped-for prize or suspected enemy to be a neutral or a friend. One really humorous encounter is related. A Massachusetts privateer approached our bellicose transport in threatening fashion, the only sign of her nationality being the apparently convincing one of the white uniforms and pointed hats worn by French 


\section{7] LIFE ON THE ATLANTIC}

soldiers, plainly discernible upon her decks. Having cleared for an encounter that looked remarkably unpromising forKnox and his friends, the true nationality of the stranger was disclosed, and the mystery of the French uniforms was solved by means of a speaking trumpet. They belonged, in fact, to a number of French prisoners whom the Yankee had captured with a French ship. She, on her part, had made precisely the same mistake in regard to the British transport. It seems to have been an economical custom of that day to make the soldiers wear their uniforms inside-out on board ship, and those of the 43rd having white linings, it gave them all the appearance, at a distance, of French troops. On their mutual errors being discovered, the officers politely asked the captain of the privateer to dinner, but the amenities were extended even to the ships themselves, which got so fast locked together that for a short time they were in a somewhat serious predicament. The Yankee skipper, says Knox, went down on his knees upon the deck and called aloud to Heaven, while his British confrere jumped into the rigging and soundly cursed both crews at the top of his voice till they had effected a separation-much the surest method, according to our diarist, of getting the job done. Another little incident is, I think, worth relating. Though Divine service was punctiliously performed on the deck of the transport, the first mate was accustomed to introduce a most scandalous novelty into the ritual. No one, we are told, was louder or more devout in the responses than this excellent man; but the ship had to be sailed, and he had to sail her. In the usual course of business, therefore, it became necessary for him to 


\section{HUMOURS OF THE VOYAGE [1757}

lift his eyes from his devotions and from time to time shout directions to the sailors on duty. These he gave with no mitigation whatever of his weekday phraseology, returning in the most imperturbable fashion after each discharge to his responses. It was not easy, says Knox, for the soldiers to preserve their decorum, particularly if one of the mate's eloquent broadsides were intermingled with the responses of the latter half of the Litany. Fogs and icebergs, whales, dolphins, and "grampuses," and all the wonders of the deep, were encountered and duly chronicled by this observant soldier, till on June 30th they slipped into Halifax harbour the first of all the fleet. There they found Loudon with his troops just landed from New York by Admiral Sir Charles Hardy, and hastened on shore to give him such news as they could-which was little enough -of the armament he was so anxiously awaiting.

Loudon, of a truth, whatever his shortcomings, had passed a most unpleasant winter. The sense of failure rested upon him as upon the whole British interest in America. There was even more soreness than usual, too, between the army and the colonists, the trouble this time lying in the much-vexed question of quarters. Seeing that Loudon and his soldiers were employed in the immediate interests of the colonies, it was not unreasonable to expect their people to show some concern for the comfort of their defenders. Boston, New York, and Philadelphia were naturally selected by the commander-in-chief for the winter quarters of his army. But the first of these cities showed much backwardness in providing shelter, while the two last were still more inhospitable and provided none at all till they were 


\section{7] DISPUTES ABOUT QUARTERS}

forced to by threats of coercion. Loudon swore that, if New York would not house the troops he had placed there, he would compel them to accommodate double the number. The men were suffering and sickening for lack of shelter, and the fierce Northern winter was already upon them. The Assembly at length gave in as regards the men, but held out in the matter of the officers. Loudon responded by sending half a dozen of the latter to the house of a prominent townsman, with a threat of sending twelve if he declined to receive them. These amenities werenotconducive to good feeling, and there were probably faults on both sides. The old English constitutional dislike of soldiers and a standing army was in the blood of the colonists, and the comparatively rigid habits of life made them dread the easy notions of the British soldier of all ranks. Still, without the British soldier the colonists would have been helplessly exposed at this time, both in person and estate, to their active enemies, and had some cause to be grateful. True, the performances of the army had not so far been brilliant, but such organization and initiative as had been shown was due in the main to British soldiers and British money. The colonial militia, according to Loudon, had an airy way of simplifying difficult operations, and talked glibly of "taking Ticonderoga" or " marching to Canada." The tendency to inflated talk is part of the atmosphere of new countries, it is almost natural to their life. Any one who has lived in them nowadays can well fancy the discourse that was often heard around the camp-fires of New. England regiments or in blockhouses on the frontiers of Virginia. But the colonies had so far shown no capacity for united effort, 


\section{GREEDY DUTCH TRADERS}

and without co-operation, and perhaps even with it, Montcalm with his veterans and his mobile Canadians would have swept the country from end to end. At any rate, the refusal to find shelter for their defenders was singularly churlish. Philadelphia hastened with joy to make the dispute another cause of wrangle with their much-harried Governor, Hamilton, whose duty it was to assist Loudon in finding quarters for His Majesty's troops. Philadelphia, however, was finally settled very much after the fashion of New York. Another cause of annoyance at this time was the persistence with which provisions of all sorts were secretly sold to Canada. In this the Dutch of the Upper Hudson were the worst offenders. The greed of their traders had been a fruitful source of trouble with the friendly Indians, and now they were active in supplying - though by no means alone in doing so-those sinews of war which Canada needed much more than arms and troops, so dismally had she failed in the primary objects of colonial enterprise.

On Loudon, however, falls the onus of having recommended for this season the Louisbourg scheme. It was not its immediate failure which redounds to his discredit so much as the tactics which left the northern colonies in the gravest peril, and the western frontiers of the others still reeking with Indian ravage. General Webb, with Munro, a brave Scotch colonel, under him, had been left with three or four thousand, for the most part raw troops, to hold the frontier against the able Montcalm and the whole power of Canada, while the great effort of the year, occupying a powerful army and a powerful fleet, spent itself on the shores of Nova Scotia, and 


\section{7] HOSPITALITY OF MONTCALM}

never even saw the first object of its attack. The important conflict of the season was reserved for the remnant Loudon had left behind him, and resulted in inevitable disaster. For while he was occupying a force of nearly ten thousand regular troops in sham fights, and cultivating vegetables where Halifax now spreads its streets and wharves, Fort William Henry succumbed to Montcalm under circumstances of such horror that its capture has rung down the ages in reams of prose and verse.

Montcalm, too, in Canada, had his winter troubles. His officers, for one thing, were continually falling victims to the charms of the Canadian ladies, which seem, according to all contemporary accounts, to have been more adapted for husband catching than for intellectual edification. What chiefly annoyed him was that most of these girls were comparatively dowerless, a sufficiently grievous sin in the eyes of a Frenchman who was also the temporary father of a large military family. Vaudreuil, it seems, secretly encouraged these matches, not merely to spite Montcalm, but with an eye to possible settlers for his beloved Canada. Gambling, too, was a passion with the wealthy clique who lived by plundering the country, and the impecunious young nobles who swarmed in Montcalm's French regiments took to the sport like ducks to water in the monotony of their ice-bound quarters at Quebec and Montreal. Balls, dinners, and receptions, though on a limited scale, and attended by more or less the same circle of guests, went merrily on. Montcalm entertained freely, to the detriment of his already encumbered estate and his ten children, not so much from inclination, apparently, as from a sense of duty. 


\section{SOLDIERS AND COLONISTS}

In his letters to his wife and mother he jokes about his growing debts, and alludes with humorous despair to the capture by British ships of certain table luxuries consigned to him by their loving hands. Nor did the French soldiers and the Canadians outside the small social circles of the capital coalesce much better than did the British regulars with their colonial allies. Indeed, such jealousies were, aye and still are, inevitable, though greatly softened and modified by altered conditions. No intelligent colonist, or Englishman who has lived in colonies would regard this statement as anything but a familiar truism. The difficulty of the home-staying, or even globetrotting Briton, is to realize the colonial's point of view, or that Englishmen and colonial-born Englishmen, as a class, are apt to jar upon each other till time and intercourse have rubbed off the angles, which, by the way, they sometimes fail to do. The exuberant and splendid loyalty of our colonies, at this moment above all, obscures these smaller matters. They are not questions for high politics, or public speeches, but of everyday life. One would call them unimportant, but for the fact that they have been the unsuspected cause of much that is not unimportant. How much greater, then, in most respects, must have been the lack of sympathy in these old days between the average individual of either stock.

It is often said, though never, I think, by serious students of the period, that Washington was practically an English gentleman living in Virginia. The punctiliousness in manner and uniformity in dress among people of respectable position at that day, lends, perhaps, some colour to this. But Washington, the Virginia planter, would have been found to differ 


\section{7] BRITISH COLONISTS}

in cast of mind and thought very materially from his prototype, an English country squire; and Washington belonged to the class who remained nearest in such matters to the traditions of the mother country. The American colonies, we must remember, were as old as Australia will be half a century hence. There was no going backwards and forwards across the Atlantic in any way comparable to what the last fifty years has witnessed. Immigration, if we except waves like that of the Scotch-Irish and Germans to certain localities, had been for some generations inconsiderable, and the growth of the country had come chiefly from within. To a not uncommon statement of English writers that the American colonists in the eighteenth century were merely Britons living in America I will venture, with some confidence, the retort that they were nothing of the kind, but, on the contrary, had developed strong local characteristics, and after their various fashions had become distinct communities. Indeed, with such a lapse of time and such changed conditions of life, how could it have been otherwise? If any proof, however, were wanting, there is plenty of it in the books of travels and the daily journals of the period. Tolerance of such departure from the manners and customs they were used to by English-speaking British subjects, could hardly be looked for in the average officer of that day, who, to say truth, was not distinguished either for adaptability or breadth of understanding. Moreover, such liberality as he possessed was no doubt at times somewhat sorely tried; but there were brilliant exceptions to this rule among the British officers, and we shall come across one or two of them in the course of our story. 


\section{LOUDON SAILS FOR HALIFAX [1757}

As the spring advanced, Loudon had concentrated all his troops at New York in preparation for their removal to Halifax. His information from England had been scanty, but his immediate business was to get to Nova Scotia and there await the reinforcements he had been told to count upon. But if his home news had been vague, he knew of a certainty that three strong French squadrons, with Louisbourg as their ultimate destination, were already on the coast, while he had only Admiral Sir Charles Hardy, with a weak squadron, to serve as escort to his own transports. In brief, if a French fleet caught him in the open sea, he was ruined. Secrecy was now Loudon's only chance, so he laid an embargo on the shipping of all colonial ports, with a view to preventing news of his movements getting abroad. This move was necessary, but naturally irritating. He then lingered on, hoping for tidings of Holborne's fleet, but none came. To move without such a security seemed, as in fact it was, a prodigious risk. But in the meanwhile May had passed away and June had half gone. His sailors were freely deserting in order to join privateers, whose profits just now were proving an irresistible temptation, and he made a curious effort to recover some of these deserters by drawing a cordon of bayonets round the whole town, and concentrating to a centre. Loudon and the admiral at length made up their minds they must risk both their men and their ships, and on June 20th they sailed out of New York Harbour. Fortune, however, favoured them, the French never guessing how great a prize lay within their grasp, and by the 30th of the month they were safe in Halifax, and in time enough to receive Holborne and his still more tardy flotilla, which arrived on July 9th. 
Loudon had now some eleven thousand men, nearly all regular troops. He was greeted by the news that there were assembled behind the formidable ramparts and batteries of Louisbourg seven thousand French soldiers, two-thirds of whom were regulars, in addition to some fifteen hundred Indians; while in the almost land-locked harbour lay twenty-two ships of the line and three frigates, carrying nearly fourteen hundred guns. Louisbourg stood alone amid the fogs of the northern seas, upon Cape Breton, which, as I have said, was an almost barren island, just severed by a narrow channel from the unsettled regions of Nova Scotia. It was a great naval station, however, as well as an important town for the period, and was of vital import to the French. It was garrisoned direct from France, and was practically out of touch with Montcalm and Canada. Later on we shall be before its walls, and have much to say about it, so will here content ourselves with remarking that these same fortifications, with seven thousand men behind them, and an overpowering fleet outside, were adjudged by Loudon and a council of war to be impregnable to the force at their disposal. So the general, after having spent six weeks at Halifax, re-embarked on August 16th, with seven of his regular battalions and his provincials, and sailed for New York, leaving the 27th, 28th, 43rd, and 46th regiments to garrison Nova Scotia.

Those that he took back with him were the 17th, 22nd, 42nd, 44th, 48th, 55th, and two battalions of the newly raised Royal Americans. Loudon, in short, performed upon the ocean a very similar manœuvre to that executed, according to the familiar rhyme, by the "noble Duke of York" upon the hill. He 


\section{THE ARMY AT HALIFAX}

carried his force, that is to say, to Nova Scotia, and brought it back again without even firing a shot or seeing an enemy. The French fleet, by its promptness in crossing the Atlantic, had saved the situation; while the British Government, by its dilatoriness, due in part to weather, had been the chief sinner. Loudon, though devoid of genius, can hardly be blamed for this fiasco. His crime was rather in initiating an expedition which stripped the colonies of their chief military strength and left vital points exposed. He received his punishment before he reached New York, for while still on the sea the news was brought out to him that Fort William Henry had fallen. Great ridicule has been cast on Loudon for his Louisbourg failure. A colonial wag had already likened him to the figure of St. George upon a tavern sign-always in a hurry, but never getting forward. He had certainly no genius for war, and was a depressing, unenterprising person, but neither his delay at New York or Halifax were his fault. At the latter place, in order to occupy the large body of troops there collected, he exercised them continually in drills and sham fights-an admirable method, one might well suppose, for improving their discipline and keeping them away from rum and out of mischief. He also occupied them in the planting of vegetables, with a view more especially to the prospective sick and wounded; and seeing that the lack of these very things was a common cause of scurvy and an indirect one of drunkenness, it is not easy to understand the jibes and taunts cast in Loudon's teeth for employing the leisure of his none too well disciplined army in these useful and profitable pursuits. General Hopson, who brought out the 


\section{7] BRITISH FLEET DISPERSED}

division from England, was second in command to Loudon at this time. Sir Charles Hay was third, the same officer who made the famous request at Fontenoy that the French Guards should fire first. He must have possessed some vein of eccentricity, for he made himself so conspicuous for open ridicule of Loudon's "sham fights and cabbage planting"-in which he declared the nation's money was squandered - that he was placed under arrest, but died before his trial. With this same division, too, there came to America another titled officer whose character was also out of the common run, though of a loftier and very different type, and, in like manner, was doomd to an early death. This was the young Lord Howe, of whom we shall hear anon.

Nor was it only failure in a military sense that marked this Nova Scotia enterprise, but the naval force engaged in it met with something more than failure, though, like the army, it exchanged no shot with the enemy. For Holborne, being reinforced on the departure of Loudon, sailed up to Louisbourg and challenged the French fleet to come out and fight him. La Motte, the admiral, felt no call to take such unprofitable risks, nor was it his duty. So Holborne, like Loudon, proceeded to sail home again. But he was not so fortunate as the general, for a hurricane struck him off that iron-bound and desolate coast, and drove him with irresistible fury against its cruel, surf-lashed headlands. One ship, with nearly all its crew, foundered on the rocks ; the rest were saved within an ace of destruction by a timely change of wind. Eleven lost all their masts, others all their cannon; and the cripples found their way eventually, as best they could, into the various North 
American harbours, La Motte, happily for them, remaining in ignorance of their plight.

When Montcalm discovered that Loudon was really withdrawing the larger and the better part of his army from the continent, his joy was hardly greater than his surprise, for he could now strike with his whole force at the feeble garrisons on the New York frontier. He recognised, of course, that an attack on Quebec was the ultimate intention of the Louisbourg force, but Louisbourg was not an Oswego or a William Henry-it was an embattled town of the first class, strongly garrisoned; and no enemy would dare to move up the St. Lawrence and leave it uncaptured in his rear. If Quebec should, peradventure, be threatened in the autumn, Montcalm could fall back to Lake Champlain in ample time for its protection. He might, indeed, have been pardoned for deeming it more probable that he and his Frenchmen would be descending the Hudson on New York enriched with the plunder of Albany. But Montcalm, too, like Loudon, had to eat his heart out waiting for an Atlantic fleet. It was not men, however, that the French commander waited for, but stores and provisions, whose scarcity was the perennial curse of Canadian military enterprise. Nor was it in this case lack of human foresight or a prevalence of western winds that kept Montcalm impotently chafing till the close of spring, but the inevitable ice-floes that impede navigation on the St. Lawrence. Throughout the whole winter Indians had been gathering at Montreal from all parts of the west and north-west, eating French bullocks and drinking French brandy, till their hosts-especially the regular officers among them-seriously doubted if their tomahawks were worth the price in money and 


\section{7] MONTCALM AND HIS INDIANS}

annoyance paid for them. Unlike the semi-civilized and so-called Christian Indians of the east, these others were all heathens, all cannibals, all naked, and armed only with bow and arrow; though, for that matter, in the days of muzzle-loaders used at short ranges in the forest, the silent, rapidly fired arrow was not to be despised. The story of Oswego and the fame of Montcalm had spread to the furthest west. The painted and be-feathered orators from the shores of Lake Superior and the prairies of the Illinois professed surprise at the pale-faced hero's scanty inches. They expected to find the head of so great a warrior buried in the clouds, but with true Indian breeding they hastened to declare that his stature was quite atoned for by the lightning of his eye. Montcalm was terribly bored by the endless ceremonies necessary for retaining their regard. He had no natural turn for Indian diplomacy, like Johnson, but endured it from a sense of duty with heroic fortitude, and proved, in fact, a remarkable success. Bougainville took some of the physical labour off his hands, and humorously relates how he sung the war song in solo fashion for an indefinite period, repeating in endless monotone that he would "trample the English under his feet." The Mission Indians, too, under the influence of their priests, were gathering in full strength. The orgies of these so-called Christians were as wild as if they had never so much as set eyes upon the cross. They went clad, it is true, but they dyed their clothes instead of their naked bodies, while their faces grinned hideously through thick layers of red and yellow and green paint, smeared on with grease and soot. All alike wore the tufted scalp-lock on their shaven heads, decorated with nod- 


\section{THE FRENCH PREPARATIONS [1757}

ding plumes of feathers; while heavy rings dragged their ears down on to their shoulders. A gorget encircled their neck, and a profusely ornamented belt their waist, whence hung the tomahawk and the scalping knife. The chief entertainment at their feasts may be described as boasting competitions, in which one performer at a time, striding up and down the line with a gory bullock's head in his hand, exhausted the whole Indian vocabulary in describing the feats of valour he had performed, and would perform again. It is probable that the boastful language of the Canadians, which so much amused the French officers, was a sort of unconscious imitation of the Indian habit. Indeed, its influence was not confined to Canada, but coloured the eloquence of the Alleghany borderer for several generations, and perhaps is not yet dead!

The store-ships arrived in due course from France, but it was the middle of July before Montcalm had collected all his forces, Indians, regulars, and Canadians, amounting to nearly 8,000 men, at Fort Carillon, better known in history as Ticonderoga. Preparations for the coming attack on Fort William Henry and the British frontier had been proceeding here this long time, and the scene, in this romantic solitude of lake, mountain, and forest, was a busy one. Since the melting of the ice in April, Lake Champlain had been alive with fleets of boats and batteaux and canoes, carrying men and material of all sorts to the narrows down which the waters of Lake George came leaping in a succession of shallow rapids. This channel was some six miles in length, a mile only at either end being navigable. The rapid portion of the river took 


\section{7] THE WESTERN INDIANS}

a wide bend, and a road was cut through the woods in a straight line from the deep water which flowed into Lake Champlain at one end, to that which gave access to Lake George upon the other. Across this rough three-mile portage the entire .material, boats included, for the operation on the upper lake, had to be laboriously carried.

By the end of July everything was complete, and the whole flotilla was launched upon Lake George ready for a start. Unwary scouting parties from the English forts had been already captured. Scalps and prisoners had stimulated the zeal of the Indians, among whom no less than forty different tribes were represented. From the far regions of Michillimackinak and the still remoter shores of Lake Superior; from the oak and chestnut forests beyond Lake Erie, where the finest farms of the fattest province of Canada now thrive among a network of railways; from the deep prairie lands of Michigan and Illinois came bands of howling and painted pagans to " trample the English under their feet," to drink their rum, plunder their settlements, and hang their scalps around their belts, or nail them on their wigwam posts. Independent bands, too, from the neighbouring and professedly neutral Six Nations were there, and even from the harried borders of Pennsylvania and Virginia some warriors, red to the shoulder in British blood, came to seek fresh fields of spoil. To mention Hurons, Ojibways and Ottawas, Iowas, Winebagoes and Algonquins would be naming but a few of them, while the Abenakis, Micmacs, and the Mission Indians were there to the full limit of their fighting strength.

On the shores of Lake George, however, before the 187 


\section{MONTCALM ON LAKE GEORGE [1757}

final departure, Montcalm had to submit to one more solemn function, and address, with simulated passion, the mass of hideous and painted humanity that he was obliged to call his children ; and, after all, if he had but known it, he had far better, upon this occasion, have been without a single man of them. He explained to them his plans, which was only reasonable, and then launched out into those astoundingly mendacious periods which, according to the code of the time, were looked upon as entirely venial. He said how pleased he was to see them-which in a sense was true enough-and then proceeded to inform them how he and his soldiers had been especially sent by the great king, Onantio, to protect and defend them against the English. When his voice gave out and his stock of backwoods rhetoric was exhausted, he presented his savage allies with an enormous belt of wampum, and possessed his soul in patience while their chiefs replied in high-flown and ambiguous metaphor, amid the solemn gruntings of the gaudy assemblage. Another whole day was consumed by the savages in propitiating their several deities, the Mission Indians going in whole bodies to confession, the unconverted warriors hanging dead dogs and old leggings on trees and "making medicine," according to each man's special fancy. The last day of July saw the surface of Lake George ruffled by the splash of thousands of oar-blades and hundreds of Indian paddles. Two hundred and fifty boats were there, carrying five thousand men, and swarms of savages in bark canoes glided in the van. The cream of French Canadian chivalry was here, and famous regiments from old France, with officers and men now hardened by American campaigning, flushed with former vic188 


\section{7] THE FRENCH ASCEND THE LAKE}

tory, and conscious, many of them, that war here meant something more than a great and bloody game. The battalions of La Sarre, Guienne and Languedoc, La Reine, Bearne, and Royal Roussillon were all with Montcalm, and only as yet in the second of those five years of war and hardship which were to close, for them, at least, in a defeat only less glorious than victory. Provisions for some weeks had been shipped; and heavy siege guns, mounted on platforms slung between boats lashed together, brought up the rear of this motley armament. Montcalm had not boat accommodation for his whole army. So Lévis, with Indian guides and twenty-five hundred men, was detailed to push his way, as best he could, through the trackless forests that overhung the western shores of the lake. At a spot some twenty miles on, and eight short of Fort William Henry, he was to display three fires as a signal of his whereabouts. The movement was successful, the British scouts having been all captured or killed, and it was not till Montcalm's whole force, by land and water, had arrived within two miles of the English fort that their approach was discovered.

Nearly all the available force for resisting the French lay in the two forts at either end of the fourteen-mile carrying-place, between the lake and the Hudson river. General Webb, now commanding in America, was in Fort Edward at the latter point; while Colonel Monroe was in charge of Fort William Henry, where there were some two thousand five hundred men of various corps, namely, six hundred of the 35th, eight hundred of a Massachusetts regiment, with some rangers, and five hundred militia from the Jerseys and New York. Webb on this very 


\section{ATTACK ON FORT WILLIAM HENRY [1757}

day, the second of August, had reinforced Monroe to the limit of his ability, having no more than sixteen hundred indifferent troops now left with him, and a weak garrison or two on the river route to Albany. Fort Edward, too, might be attacked simultaneously with William Henry, and that by another route, namely, the long stretch of water running from Champlain southwards and parallel to Lake George, known as Wood Creek.

Fort William Henry lay close upon the shore of Lake George. It was square in shape, with corner bastions, and walls of hewn logs laid as cribs and filled in with heavy gravel, impregnable to rifle fire or small artillery, but a poor defence against heavy cannon. There was not room for the whole force within the fort, and a great part of the provincial troops were intrenched on some rising ground six hundred yards away with marshes upon either side. Montcalm was able at once to cut off the whole position from either retreat or succour, by sending de Lévis round behind it with three thousand men to occupy the road and only route to Fort Edward, where a famous partisan leader, La Corne, with a portion of the Indians, soon after joined him. Montcalm now proceeded to examine the fort, and came to the conclusion it was impregnable to ordinary assault. He prepared, therefore, to reduce it by regular siege, an apparently easy matter, with his heavy guns and large forces, which numbered in all something like eight thousand men. As a preliminary, however, he sent the faithful Bougainville to offer Monroe terms for surrender. He pointed out that help was impossible, which, was quite true; that his own numbers were overpowering and his guns 


\section{7] MONROE OVERMATCHED}

to match ; above all, that a large part of his Indians had come from the wild west, and that when the surrender came-which was inevitable within a few days-and blood had been shed, he might be unable to restrain their diabolical ferocity. Monroe briefly replied that it was his duty to hold the fort, and he should do his utmost to maintain himself. Montcalm then opened his lines across the south-western corner of the lake at a range of 600 yards. Hundreds of men worked in the trenches night and day under a fire from the fort that, after the first few hours, could do them but little damage. The Indians proved refractory and of little use. Montcalm wanted them to scout southwards towards Fort Edward and the Hudson, but they were sore at heart because they had not been consulted as to the operations, and the greater part of them hung about behind the lines, or lolled in their canoes or fired futile shots at the fort. Monroe, in the meantime, was sending eager messages to Webb for help, and Webb has been blamed for not responding. His previous record has, perhaps, made his critics unfair. He could not help Monroe, for his weak force alone barred the way to Albany, and to detach a portion of it would have been to sacrifice that portion either to the strong forces of de Lévis in the woods, or at the almost inevitable surrender of Fort William Henry.

In three days the best of Montcalm's forty guns were in position, and in two more were advanced to within 200 yards of the fort, whose ramparts were flying in fragments before their fierce discharges. Two sorties were tried, both from the fort and the intrenched camp beyond, but were easily repulsed. Webb might have done something in this way, 


\section{SURRENDER OF THE FORT $[1757$}

but messengers could no longer get through to Fort Edward and arrange for simultaneous action. Smallpox, too, had broken out in the garrison, and was spreading rapidly. Monroe seems to have had some vague hope that provisions, the chronic difficulty with all French Canadian armies, might fail the besiegers, for in that wilderness every ounce of food had to be carried. But Montcalm had made special efforts this time, and, moreover, had the good luck to capture 150 head of cattle belonging to the garrison.

Bougainville was again sent to propose terms, and conducted blindfold into the fort, but again the brave Monroe, though he was shown an intercepted letter to himself from Webb to the effect that assistance was hopeless, refused to treat. Another twenty-four hours, however, saw such warm work that a council of war was called, and the white flag was at length raised upon the walls.

For the whole French artillery was now intrenched at close range. Many of the English guns had burst, and only about half a dozen were fit for service, while their ammunition was nearly exhausted: so Colonel Young, commanding a detachment of the Royal Americans, or 60th, then newly raised, was sent to arrange terms of capitulation.

The garrison were at Montcalm's mercy; they had no alternatives but death or surrender, and there were many women among them. It was agreed that the troops should march out with the honours of war, all ranks retaining their personal effects. Everything else in the fort was to be given up. Prisoners of war in actual fact they could not be, for food was much too scarce in Canada for Montcalm to indulge in such luxuries; indeed, the people themselves were, 


\section{7] THE GARRISON MARCH OUT}

at that very moment, on something like half rations. The British were to be escorted to Fort Edward, and remain on parole till an equal number of French prisoners should be delivered safely at Ticonderoga, each batch of the latter as they came in setting free from their obligations an equivalent number of the British. In recognition of the bravery of the defence, the garrison were to take with them a single gun, a six-pounder. The loss had been inconsiderable-some hundred and twenty men on the British and half as many on the French side. It was understood, however, that these articles could not be signed until the savages had given their consent. This, however, they were induced to do, and both sides proceeded forthwith to put them into execution.

The fort was evacuated at mid-day on the 9th, when the garrison, together with the women and children, marched out to the intrenched camp, which was of course included in the surrender, a French regiment being detailed to secure them against interference on the part of the Indians. De Bourlamaque, entering the fort with a party of regulars, set a guard over the ammunition and stores. Everything else was abandoned to the Indians, who gave an earnest of what was coming by instantly murdering a dozen or more sick men, who had been left according to the articles of agreement in Montcalm's charge. There was not much plunder in the fort itself, so the intrenched camp, where all the British were huddled without arms save the bayonets of the 35th, soon swarmed with bloodthirsty demons, baulked of what they regarded as their lawful prey, and with hands twitching viciously at their tomahawks. Numbers 


\section{THE INTRENCHED CAMP}

of Canadians, whose morals in warfare were little higher than those of the savages, mingled with the now excited throng, and showed unmistakable sympathy with its temper. There was great confusion throughout the whole afternoon, the Indians jostling and insulting the prisoners, and making attempts from time to time to wrest their personal baggage out of their hands. The liquor was either under guard or destroyed, else no efforts of Montcalm and his officers, which individually were considerable, could have prevented a general massacre before night. But these efforts of the French officers, though sincere enough, were not intelligently directed, nor were they backed at the right moment by proper force. The whole business in fact was grossly mismanaged. Canadian militia were stationed at some points as a protection to the prisoners, though the Canadian militiaman looked on plunder or scalps as the rightful price to pay for Indian assistance, and was by no means averse to taking a hand in it himself. The restraint which Montcalm had exercised over the Indians at the capture of Oswego in the preceding year was regarded by all Canadians, from the Governor downwards, as a pernicious European prejudice. Mercy and pity had no place in backwoods warfare, and it is only fair to say that the New England rangers often paid the savage and the Canadian back in their own coin. But the responsibility on Montcalm was very great, and his failure to estimate its gravity is a lasting stain on his memory. Bougainville writes that his chief himself used every effort, and made urgent appeals to the Canadian officers who had personal influence with the savages to avert the threatened catastrophe. It would have 
been far better if he had promptly called up his 3,000 French troops with fixed bayonets, who would have overawed with ease any attempted outbreak of the Indians. On this means of protection, however, he drew most slenderly, and seems to have contented himself with appeals to Canadians and interpreters, many of whom would have been inclined to look on a general massacre as something rather of a diversion than otherwise.

The afternoon and night of the 9th were passed anxiously enough by the two thousand British of all ranks, besides the women and children, within the intrenchment. They were to march in the morning, and as soon as the escort of 300 regulars, an absurdly weak one, seeing the temper of the savages, should arrive. Seventeen wounded men lying in a hut under care of a surgeon were the first victims. The Indians, brushing aside the sentries, dragged the wretched men from their beds, and butchered them within a few yards of a group of Canadian officers, who did not trouble even to remonstrate. As the defenceless column of prisoners began to move, the savages fell to indiscriminate plundering. The men strenuously resisted this attempt to rob them of their personal effects. Monroe protested loudly that the terms of the capitulation were broken, and appealed to the French officers of the escort which was drawn up close by. The latter seem to have been cowed by the turmoil around them, and had not even the presence of mind to send for support to the army which lay a few hundred yards off. All they did was to urge the British to give up their property for the sake of peace, and to get away as fast as possible. Many indignantly refused this mean advice. Others fol- 


\section{THE MASSACRE}

lowed it, and a certain amount of rum from private canteens thus found its way down the throats of the yelling savages and made them still more uncontrollable. No sooner had the column got clear of the intrenchments, and started upon the forest road to Fort Edward, than all restraint was thrown off, and the Indians fell upon the rear, stripping both men and officers to their very shirts, and instantly tomahawking those who showed resistance. The war whoop was now raised-by the pet converts of the Canadian priesthood from Penobscot it is said-when the rear of the column, rushing forward upon those in front, a scene of horror ensued that has been described by many pens. Women and children were dragged from the crowd; some were tomahawked, others carried off as prisoners to the woods. Their shrieks and cries, mingled with the hideous yells of the Indians and the shouts and curses of the impotent British, made an unforgettable scene. Montcalm and the French officers threw themselves among the savages now half drunk with rum or blood, and did all that men armed only with authority and not backed by force, as they should have been, could do. The small French escort in the meantime looked on helplessly, the crowd of Canadians approvingly, as the scene of blood and plunder and outrage continued.

At length the exertions of Montcalm and Lévis, Bourlamaque and other French officers, had some effect; but it was only by promising payment for the captives seized by the Indians that some sort of order was restored. The precise number of both sexes thus butchered under the eyes of the French, while unarmed captives of war, is a matter of dispute. Lévis counted fifty corpses on the field, while sick 


\section{7] AN UNPARDONABLE CRIME}

and wounded men to half that number had been murdered in their beds, and numbers more dragged off into the woods. It seems probable that a hundred would be a fair estimate of those slain.

Over six hundred were made captives by the savages, and it required the utmost exertions on Montcalm's part, with a considerable outlay of money, to recover about half of them. The Indians would not give up the remainder on any terms, and eventually took them to Montreal, where Vaudreuil, who, in his character of Canadian, looked with much toleration on Indian outrage, had to pay for the amusement this time with large sums out of his scant treasury by way of ransom. The whole body of Montcalm's Indians left for Canada the day after the massacre, carrying with them the three hundred prisoners above alluded to, and no difficulty was experienced in getting the rest of the captured British garrison in safety to Fort Edward.

There is absolutely nothing to be said in defence of the French in this affair. That they did not dare to run the risk of offending and alienating their Indians is, of course, the explanation, though surely no extenuation of such ignoble conduct. It is one of the worst stains upon the annals of their arms in America. They would have been bound by humanity only in the storming of a fort, but after a formal capitulation, they were bound not merely by humanity, but by the most elementary rule of military honour, and it is satisfactory to think that they paid dearly for it. The British Government, as a matter of course, repudiated their part of the contract, and not a French prisoner was sent to Montreal, nor was the parole of the garrison taken any account of. The 


\section{EFFECT OF THE MASSACRE [1757}

memory of the massacre drove many a bayonet home in the coming years of British success that might otherwise have been stayed in mercy, and many a Canadian sued in vain for his life at the hands of the New England Ranger who might formerly have been spared. Remember Fort William Henry became a terrible war cry in many a battle and in many a bloody backwoods skirmish. The French knew it well and felt that it added a fresh terror to defeat. The first impulse of a disarmed or captured Canadian was to protest by voice and gesture that he had not been present at that accursed scene.

The growing scarcity of food in Canada saved the forts on the Hudson and, probably, the flourishing town of Albany itself, from being captured and sacked by the French. Word was sent that it was of the first necessity, that the now ripening harvest should be gathered, and there were not men to do it. So the French turned their attention to the destruction of the British fort and all its dependent buildings. Great bonfires were made of the logs forming the ramparts, and into them were cast those bodies of the dead which had not been buried. As a fortress the place ceased to exist. Great armaments, some of them as luckless as the garrison of 1757 , were yet to camp on its ashes, and again to break the silence of the forests with the din of war. But for the present solitude reigned over the devoted spot; the sounds of human life gave way once more to the weird cry of the loon and the splash of the summer-duck upon the lake, the boom of the bull-frog in the marsh, the drumming of the ruffed grouse on the hill. The waves of conflict fell back for a brief space, and left 


\section{7] THE FORT DESTROYED}

the charred logs and fire-scorched stonework, and the trampled, stump-strewn cornfields of William Henry, as the sum total of a year's success and failure. 


\section{CHAPTER VII}

TUDON, it will be remembered, received the fateful news from Fort William Henry while yet upon the ocean, and it must have been a bitter moment when he realized how completely he had been outgeneralled. For the bloodless failure in Nova Scotia he could blame others; for the bloody tragedy on Lake George his own tactics were wholly responsible. He relieved his temper by vowing vengeance against Montcalm as an abettor of savages and murderers, and sent word by a fast-sailing craft to Webb to hold out at Fort Edward till he could send him reinforcements. It was the last of August when he landed his troops at New York. But the French, as we have seen, had, for urgent reasons, to abandon all attempts at an advance up the Hudson, and had returned in part to Canada to save the harvest, and in part to Ticonderoga to make that post secure. Loudon is supposed even now to have cherished thoughts of attacking the French fortress, but if so he soon abandoned them on a closer view of the situation. In intention he was the very soul of energy; in execution he remains, whether from his fault or his ill-fortune, the typical sluggard of the Seven Years' War in America.

Sir William Johnson had joined Webb at Fort Edward, with a small band of his Indians, just 


\section{7] DESTRUCTION OF SETTLEMENTS}

about the time of the fall of William Henry, and a day or two after, but all too late, raw militia had begun to pour in by the hundred. Their behaviour, however, was so mutinous, and their conduct so riotous, that Webb was glad enough to dispense with such troops and disband them, now that their services were no longer needed.

Only one incident of moment marked this depressing autumn of a year of disgrace and failure, and that of a kind by no means calculated to lighten the general gloom on the Mohawk River. Near those forts that Webb had, it will be remembered, destroyed in his panic after the fall of Oswego, was a colony of thrifty Palatine Germans. Far behind civilization, in this beautiful and fertile valley, these industrious settlers had been labouring for forty years, and were now a community of some three hundred souls, well situated in comfortable homesteads and tilling valuable farms. It was a popular creed among French Canadians that the Germans of the British colonies were dissatisfied-a queer delusion in regard to people who revelled in an independence far more novel to them than to Englishmen. By way of encouraging other Germans to crave for the paternal government of France, one, De Bellaitre, was despatched by Vaudreuil with a hundred Canadians and two hundred Indians to read them a lesson. Paddling up the St. Lawrence from Montreal, past the now familiar Thousand Islands into Lake Ontario, they struck southward to Lake Oneida, crossed the portage of the Mohawk watershed, and fell suddenly upon the unhappy Teutons, killing every man that resisted, destroying their livestock, and carrying off more than a hundred women and 


\section{7] BRITISH PRISONERS AT MONTREAL}

children into captivity. A small British detachment from Fort Herkimer hurried up, but they were too late, and in any case too weak. Lord Howe, commanding further down at Schenectady, was strong enough, but he arrived much too late, and found nothing but the smoking ruins of homesteads and hundreds of slaughtered sheep and cattle.

In the meanwhile, the Indian heroes of Fort William Henry, who had been almost as great a curse to their friends as to their foes, paraded their wretched prisoners at Montreal, and by no means yielded them all up to the not very insistant overtures of Vaudreuil. One of these English captives, writes Bougainville, who was just then on the spot, they killed in presence of the whole town, and forced his miserable companions to devour. It is even asserted by French writers that mothers were compelled to eat portions of their own children. Bougainville shuddered at the horrors he saw, but was impotent, for Canadian public opinion was lenient to these little Indian vagaries so long as other people were the victims. Bigot the Intendant, no man of war, but an expert in erooked contracts, calmly stated that the savages must be kept in good humour at any cost. Vaudreuil, for his part, was quite proud of his magnanimity in purchasing, with Government brandy, the lives of men who had surrendered to his troops under signed articles; while Indians reeled in crowds about the rude streets of Montreal, insolent, offensive, drunk, and dangerous.

It was a gloomy enough winter, this one of 1757-58, in the British provinces. Loudon's troops had retired to isolated snow-bound forts, or to their much-grudged but no longer disputed quarters in the principal cities. 


\section{LOW EBB OF BRITISH FORTUNES [1757}

It was the lowest point ever touched by Anglo-Saxon fortunes in America. Oswego and William Henry were scenes of desolation; Louisbourg was contemptuous and defiant behind its bristling rows of cannon and massive ramparts; the colonists even of New England were disheartened and disillusioned as to the invincibility of British troops, and sore both with their generals and their officers. The frontiers of the more southern colonies still ran with blood, and the labours of a generation on a belt of country nearly four hundred miles in length had been swept away. Washington, struggling almost alone with provincial legislatures, as twenty years later he struggled quite alone with the continental congress, had patiently striven to mitigate the misery. He had now been over two years at the frontier village of Winchester, in the valley of Virginia, eating his heart out in vain endeavours to stem the hordes of Indians led by Frenchmen, who swarmed across the stricken borders of the middle colonies. "I have been posted," he wrote in the preceding spring, "for more than twenty months on our cold and barren frontiers to perform, I think I may say, an impossibility; that is, to protect from the cruel incursions of a crafty, savage enemy a line of inhabitants more than three hundred and fifty miles in extent, with a force inadequate to the task." He was still only twenty-five, but a head and shoulders above any colonial soldier outside New England. He had no chance of gain or glory with his thousand or so " poor whites," ill-paid and discontented, and recruited with infinite difficulty. His officers were often of no better discipline. One of them, he tells us, sent word on being ordered to his post, that he could not come, as 
his wife, his family, and his corn crop, all required his attention. "Such," says Washington, in a white heat, " is the example of the officers, such the behaviour of the men, and upon such circumstances the safety of this country depends." Three colonies, Pennsylvania, Maryland, and Virginia, with some halfmillion whites, to say nothing of rude and populous North Carolina, could only wring from this large population a wretched, half-hearted militia of 2,000 men, recruited largely from the burnt-out victims of the frontier. Where, one may well ask, were the squires of Virginia and Maryland, who swarmed along the eastern counties of both provinces, and whose comfortable homesteads reached to within a hundred miles of the scene of this bloody war, of their fellow-countrymen's long agony, and of the impudent invasion of their country? To mention a dozen or two young men of this class who rallied to Washington, would only be to aggravate the case, if such were possible, in the face of these statistics. Men of substance and education, accustomed to horse and gun, "outdoor" men in fact or nothing, were quietly staying at home by thousands, unstirred by feelings of patriotism or vengeance, and apparently untouched by the clash of arms and the ordinary martial instincts of youth. Their grandfathers had fought; their sons were to fight; their descendants were in the last civil war to be among the bravest of the brave. What was this generation doing at such a moment? Washington, whose local patriotism no one will dispute, and whose example shone like a beacon light amid the gloom, cursed them often and soundly in his letters for doing nothing. It was fortunate for these colonies 


\section{7] INDIFFERENCE IN THE COLONIES}

that Pitt came forward to save them. The people of Maryland and Virginia are more than most other Americans proud of their ancestry-not because they were thrifty merchants, for they ignored commerce; not because they were famous navigators, for they were not sea-goers; not because they were thrifty farmers who made two blades of grass grow where one had grown before, for they were sad economists in this respect. The sentiment is by way of being that which holds good in Europe, and regards ancestry in the accepted sense of the word as synonymous with an aptitude for arms. But the tobacco squires of the Seven Years' War were lamentably wanting in those generous and martial impulses which supply almost the only motive for pride of race, and quite the only one where high culture and learning are absent, as was here the case. There is no traversing the facts; they are bare and patent, and it has always seemed to us one of the most unaccountable incidents of American history. Think of South Africa to-day, and, indeed, the parallel is not an inapt one, save that in the racial struggle for North America the prize was greater. Think of the colonists of every class so lately crowding by thousands to the front, though none of their women, children, or friends have been scalped and murdered. Indeed, for that matter, turn to Massachusetts at that day, who alone sent to the front ten or fifteen thousand close-fisted, industrious farmers, men whose labour was their daily bread, and whose absence from the homestead was, for the most part, a serious matter.

"Nothing," wrote Washington, "keeps me from resignation but the imminent danger to my country. The supplicating tears of the women and moving 205 


\section{SUFFERING IN CANADA}

petitions of the men melt me into such deadly sorrow, that I solemnly declare, if I know my own mind, I could offer myself a willing sacrifice to the butchering enemy, provided that would contribute to the people's ease."

Washington was giving up a life of ease and comfort, neglecting an estate to whose management he was greatly attached, and those field sports which, next to fighting, were the passion of his life. Here, however, on this shaggy blood-stained frontier, without means to fight effectively, neither glory nor even thanks were to be gained. He lost his temper more than once, and wrote incontrovertible but imprudent letters to the Virginian authorities at Williamsburg, falling thereby into the bad books of the gentlemen who regarded the state of the frontier with such prodigious equanimity. At one time an obscure Maryland captain of thirty men, who held a king's commission, had claimed precedence of the young colonel and commander of the Western Frontier. Washington had then ridden the whole way to Boston-four hundred miles-to put the matter straight with Shirley, then in chief authority, and ensure against its recurrence.

The Canadians, too, had suffered greatly this winter. The troops were reduced to small rations of horse flesh, and only the tact and ability of de Lévis averted a general mutiny. The small social circles of Quebec and Montreal, however, lacked for nothing, but danced and dined, and intrigued and sleighed in merry parties along the frozen river or through the silent pine woods white with their load of snow. The Bureaucracy, with Bigot at their head, followed with unabated ardour their career of fraud and 206 
trickery. Never were a king and his subjects more flagrantly cheated. They sold the provisions sent from France to the relief of the colony and pocketed the money. They fixed the price of grain by law, bought it all up, and then retailed it at famine prices. They sold Government supplies twice over in collusion with the officers who had to sign the receipts. They purchased supplies for the king's use through so many confederate hands, that the price was three or four times that originally paid for the articles. They intercepted food granted by the king to the hapless Acadian refugees, sold the larger part back to his Majesty at high prices, and half starved the miserable outcasts on what was left. The command of an outlying fort was regarded as equivalent to a small fortune, and bestowed accordingly on friends and relatives. The usual method was to give vouchers for twice or three times the amount of stores actually purchased, and to exchange the Government presents sent to the Indians for skins or furs. It may well be asked, What was Montcalm himself, the soul of honour, saying to all this? As a matter of fact, his position under de Vaudreuil, who was himself mixed up in the frauds, was sufficiently delicate to make interference difficult. But Montcalm did take means to acquaint the home Government, already suspicious of the vast sums of money demanded, with the condition of affairs, and their eyes gradually opened. It is not perhaps wholly to be wondered at that France lost some of her enthusiasm for an offspring that tugged so incessantly at the strings of her almost empty purse, and showed so little profit for the investment. The letters to Vaudreuil from his Government at last grew harsh and threatening, as the 


\section{PITT TO THE RESCUE}

rascality of the whole business began to dawn on the hitherto credulous Ministers of Marine. But it was too late. Pitt was about to settle down to the greatest work ever achieved by a British Minister. The colony was now entering a death-struggle in which ledgers and vouchers would be for the time forgotten; and there is good reason to suppose that many a tell-tale document went to feed the flames which the British torch or shell fire had ignited. But the corruption of the Canadian civil officials, and a great number of the colony officers, did not interfere with the actual fighting power of the military machine, which was itself a hardy plant. Food and clothes and ammunition for men on active service were always forthcoming. If they had not been, Montcalm would have asked the reason why, with a forcible authority, such as in civil affairs he could not call to his aid.

It was at the opening of the ever-memorable year of 1758 that Pitt, free at last from the shackles of his predecessor's plans and his predecessor's generals, applied his great gifts to the task before him. Great Britain was sunk in despondency. Chesterfield declared we were "no longer a nation." If any man had asserted that in two or three years we should take our place at the head of all nations, never as a worldpower to again relinquish it, he would have been accounted as fit only for Bedlam. Many, though they could not know what we do now of the then state of France and Canada, thought we should be stripped of all influence, if not of all foothold in America, while the fear in England of a French invasion returned as regularly as the summer leaves.

To free his mind of all paltry cares, Pitt had flung the sordid part of government to Newcastle, who 208 


\section{8] MAGNETISM OF PITT}

revelled in it. It was part of his bargain that where the honour or the safety of the nation were at stake his word was law, his appointments indisputable; and he proceeded at once with fine audacity to make hay of privilege, of family interest, of seniority. The incapables were relegated to obscurity, and those who might have caused annoyance were soothed by Newcastle with pensions, compliments, or honours, which most of them perhaps preferred to service in America. Small pay and brevet rank for his servants seems to have been, too, a sop that Pitt felt it advisable, for the sake of peace, to throw to the long list of rejected generals, who seem therein to have found some strange consolation. Fortunately, Pitt's young men had, for the most part, souls above titles or lucre, though Wolfe was hard pushed for necessary money; and his widowed mother, after his death, made futile representations to Government for some financial recognition of the work done by the conqueror of Quebec. Pitt's plans were not merely to reduce France to her legitimate sphere in America, and make her harmless against Great Britain in Europe, but to drive her wholly from the western hemisphere, to wrest from her every possession she had outside her own borders, to leave her crushed, humiliated, and powerless for aggression.

To this end he appealed with impassioned fervour to the heart of England, and by a genius, unequalled in our history, and that seems to us who have not seen or heard him aimost magical, brought an apparently half-moribund nation into an ecstasy of patriotic ardour. Every one who approached the great statesman eaught the inspiration, and every man in England who had a heart at all felt the 209 
blood coursing more briskly through it. Those whom Pitt called especially to serve him and maintain the nation's honour went to the camp or to the wilderness with an enthusiasm for their chief and country, and a sense of exhilaration that had for long been almost wholly lacking.

With Pitt's assistance in Europe to the gallant Frederick of Prussia we have nothing to do. It will be sufficient to say that the Duke of Cumberland's reverses were fully avenged, and the French repulsed at every point.

As for the American campaign, which constitutes our story, there was not much opening for strategic ingenuity. As I have endeavoured, with perhaps undue reiteration, to make clear, there were certain routes through the northern wilderness by which French and English could seriously attack each other, and none other. There was nothing new, therefore, in Pitt's American programme for $\mathbf{1 7 5 8}$ but the men who were to carry it out and the kind of spirit which animated them. Above all, there was the enthusiasm with which the people of England -particularly of that substantial but unrepresented middle class to whom Pitt's personality appealedsupported him with heart and purse.

Loudon had abandoned the only true path of American warfare, probably because his predecessor, Shirley, a civilian, had planned it, and, as we have seen, left New York almost defenceless in a vain attempt to gather laurels upon distant shores. It was no thanks to him that the colony was still in British hands, and Pitt now recalled him with contemptuous brevity. It is only to be regretted that Abercromby did not sail in the same ship. The 
excuse put forward for making such concession to routine in the matter of this luckless officer is, that Pitt felt secure in the fact that the young Lord Howe, one of the most rising soldiers and most estimable characters in the British army, would be at his right hand; but, however probable, this is, after all, but a matter of conjecture.

Ticonderoga, Fort Duquesne and Louisbourg were to be the objects this year of three separate expeditions. Of the first, Abercromby, now in America, was to be in command; and of the second, Brigadier Forbes, a Scottish soldier of merit and energy. Louisbourg was made a matter of prime importance, as the fleet was to co-operate. Amherst, a colonel serving in Germany, was recalled to take command of the land force with the rank of General, and under him went three brigadiers-Lawrence, whom we have met before in Nova Scotia, Whitmore, of whom little was known, and lastly, in a good hour, James Wolfe.

As Wolfe's name is the most luminous by far in the annals of the war, a few words on the previous record of this illustrious young soldier will not be amiss. He was of that Anglo-Irish stock which has given to the nation so many leaders, though his particular branch of the family had been back in England again for two or three generations when the hero himse was born. His father was a general in the army, who, in youth, had seen service under Marlborough, and in advanced middle age, after Walpole's long peace, took the field again in South America and Scotland. ${ }^{1}$ His mother was a Miss Thompson, daughter of a

1 Wolfe's father went north with Wade in the '45 as a General of Division, though very infirm and taking little part in the operations. 


\section{CHILDHOOD OF WOLFE}

Yorkshire squire. The Wolfes had just taken a small but picturesque Tudor house which still stands in the outskirts of the little Kentish town of Westerham, when their eldest son, James, was born. ${ }^{1}$ There he and his brother, who died in his first campaign, spent their early youth. In the gardens of Squerryes Court, close by, an inscribed cenotaph marks the spot where the hero of the Plains of Abraham received the envelope containing his first commission while playing with his friends the Wardes, whose descendants still live there, and in the stately Queen Anne mansion are still treasured those hundred and seventy or so well-written and characteristic letters in which the young soldier unconsciously tells the story of his life.

There is an old Welsh legend relating how Owen Glyndwr, while still a babe in arms, if he caught sight of a sword or a spear, gave those in charge of him no peace till it was placed in his infant fingers. Wolfe, not in legendary lore, but in actual deed, was only less precocious in his martial ardour; for when his father, then commanding a regiment of marines, was waiting in camp to embark on the luckless expedition against Carthagena, the boy-then just thirteen -brushing aside his mother's tears and entreaties, and overcoming his father's less-pronounced objections, actually succeeded in getting himself attached to the regiment as a volunteer. Happily they were not yet on board when he was seized with some childish malady and sent home again, and put to school.

At fifteen, however, Wolfe actually received his commission, and joined Duroure's, or the 12th regi-

1 Wolfe was actually born in the Rectory close by, which his parents were temporarily occupying. 


\section{8] HIS CHARACTER AND SERVICES}

ment of foot. At sixteen he fought in the battle of Dettingen, acting as adjutant throughout the whole of that sanguinary day, which his boyish pen has graphically described. Proud of his profession and of his country, fearless in battle and ardent in his duties, he got plenty of the work that was in those days crowded on a willing horse. At the breaking out of the Jacobite rebellion of '45, though barely nineteen, he had won his way, without backing or interest, to be brigade-major. He fought through this campaign in Barrel's regiment (the 4th foot), and afterwards on the Continent, where he was wounded at Lauffeldt. He then had some ten years of home service in command of the 20th regiment, partly in Scotland, doing police work among disaffected Highlanders, and partly in southern garrisons, chafing vehemently the while at such enforced inactivity. In such times, however, he never lost an opportunity of improving himself, studying mathematics and classics, as well as military history. He fished and shot when the chance offered with equal ardour. He was fond of society, both grave and gay, was a graceful and industrious dancer, and expected his subalterns to be the latter at any rate. All Wolfe could do in the years of peace between the two wars he did do in the path of professional duty, for he left his regiment the best disciplined of any in the British army, and one much sought after by ambitious youths and prudent parents. He was a singular blend of the dashing fighter, the strict disciplinarian, the ardent student, the keen sportsman, and society man. He was religious without ostentation, studious without any taint of the prig, and brave even to recklessness. 


\section{ADMIRALS HAWKE AND OSBORN [1758}

The long, gaunt figure, the pale, homely face and red hair, of which Wolfe himself was always so humorously conscious, are a familiar memory to most people, while his wretched health is also a matter of common notoriety. He loved as ardently and as faithfully as he fought, for being unsuccessful in his first attachment, - a daughter of the Sir Wilfrid Lawson of that day being the object of it,-he remained for years true to her memory, and proof against all other charmers till within a few months of his death. What kind of a son he was his correspondence shows. Almost the only thing he would not do for his mother was to marry any of the heiresses that excellent lady was in the habit of pressing upon his notice. In 1757 he had been sent as fourth in command of the luckless expedition against Rochelle, led by Sir John Mordaunt, and was the only man who came out of it with any credit. Even this consisted only of intentions which the supineness of his chief forbade him to carry out; and that so slight an incident caught Pitt's attention is characteristic of his genius. Wolfe's professional ardour in those dull times, together with his rather uncommon temperament, made him regarded in some quarters as eccentric. Some one told George II. he was mad. "Mad, is he?" snarled out the old king, soured by the recent displays of British strategy. "Then I only hope he'll bite some of my generals."

But Pitt's first care this year was to prevent, if possible, any men or provisions from erossing the ocean for the relief of Canada. Armaments for this purpose were known to be preparing in Rochefort and Toulon, so Hawke and Osborn were sent with sufficient ships to effectually thwart both enterprises. As 
a big fish chases a shoal of frightened fry on to the shallows, so Hawke drove the French fleet at Rochefort helter-skelter on to their own rocks and sandbanks, to their very great detriment, while Osborn guarded the Straits at Gibraltar, a position which the armament at Toulon did not venture to dispute.

Boscawen, who was to command the North American fleet and take Amherst's army to Louisbourg, was a son of Lord Falmouth and a grandson of that too-famous Arabella Churchill, who had married after her relationship with James II. had ceased. He was therefore of the Marlborough blood; but Boscawen's nicknames of "Old Dreadnought" and "Wrynecked Dick" suggest rather the bluff seadog of the period than any flavour of coronets and courts. In any case he was known as a good sailor, and, what at this moment was equally important, might be trusted to act cordially with Amherst, and not follow the too-prevalent fashion of thwarting the soldier because he himself was of the rival trade. For there was not much love lost in those days between the services, and they were both apt to show their feelings only too plainly for the public welfare when called upon to act together. The sailor, from the nature of his services on these occasions, was the greater sinner, and national enterprise, strange though it seems now, had suffered often and sorely from the friction. The naval officer of those days, as everybody knows, was, with some exceptions, a rough diamond. Taken as a class, he was not the social equal of the soldier, and this in part, no doubt, accounted for his unconciliatory attitude. But a change, both in the personnel and the sentiment of the navy, was now creeping in, and Boscawen amply proved his capacity for putting 


\section{BRITISH SAIL FOR HALIFAX [1758}

professional prejudice aside when the honour of his country was at stake.

It was the 19th of February, 1758, when the Admiral sailed out of the Solent with Wolfe on board and a fraction of the army which was to operate against Louisbourg. The rest of the force was to be made up by troops from Loudon's army of the previous year, which were waiting at Halifax. Amherst was to follow immediately. Buffeted by winds from the very outset, and forced for some days into Plymouth, it was nearly three months before the fleet appeared in Chebucto Bay and dropped anchor in Halifax harbour on May 10th. Quebec, of course, was in the mind of Pitt and of his generals, should Fortune favour them, and that quickly, at Louisbourg; but in the matter of weather she had so far been the reverse of kind, and they had already lost a month out of their quite reasonable calculations. Amherst arrived a fortnight later, and with a fleet of nearly 200 ships of all kinds, and an army of 12,000 men, sailed out of Halifax harbour and bore away through heavy seas before a favouring wind to Louisbourg. On June 1st the soldiers had their first sight of "the Dunkirk of the North," lifting its formidable ramparts behind a white fringe of raging surf.

Louisbourg, as may perhaps have been already gathered, was no town such as Boston or New York, or even Quebec and Montreal, the focus, that is to say, of a surrounding civilization; but, on the contrary, it stood like a lone oasis between a shaggy wilderness and a grey sea, the sport of storms and fogs. It counted a population of 4,000 souls, some of whom were fish-merchants and some priests, but many more were engaged in various pursuits con- 
nected with the trade of war. Louisbourg, indeed, scarcely professed to represent the interests of peace ; it existed for war and for war alone. France, at the late treaty, had strained every diplomatic nerve to recover the town from the grip of the New Englanders, who in the last war, with the help of a British fleet, had seized her in a moment of comparative weakness. England, deaf to the cries of her colonial subjects, had then yielded, and was now paying the price of her blindness. With her fine harbour, her natural defences, her commanding situation in the northern seas, Louisbourg only existed as a menace to the enemies of those who held her, a refuge to the hunted, a rallying-point for the hunters of the ocean; the scourge of Nova Scotia, the curse of the Newfoundland and New England coasts, and a name as familiar then in Europe as it is now forgotten. Since its restoration to France, a million sterling had been spent on the fortifications. Franquet, the eminent engineer, assisted by skilled artificers, had done the work, and from behind its two-mile circle of stone bastions and massive curtains of well-mortared masonry nearly 400 cannon frowned defiance upon all comers. Drucour was now governor, while about 4,000 men, mostly French or Canadian regulars, in addition to the same number of inhabitants, with a year's provisions, awaited Amherst behind the walls. But this was by no means all, for the Sutherland, of sixty guns, met the British fleet in the offing with the news that seven line-of-battle ships and five frigates, carrying 550 guns and 3,000 sailors, were at anchor in the harbour to assist in the defence.

Louisbourg harbour was some seven miles in cir217 


\section{DEFENCES OF LOUISBOURG}

cumference, with an entry so blocked with reefs and islands that the actual passage was not half a mile in width. The town occupied the point of the promontory which guarded the western mouth of the harbour, and formed a triangle : one side being lashed by the breakers of the Atlantic, the other washed by the land-locked waters of the harbour, while the third, or base, facing the only approach by land, was the most strongly fortified. Goat Island, in the centre of the harbour mouth, commanded the eastern or navigable channel, and carried a battery. But these, after all, formed only a portion of the strength of Louisbourg. For several miles to the west, the only side from which a force could to any practical purpose be landed by sea, the shores of the bay of Gabarus presented an iron barrier of cliffs and reefs, only broken here and there by narrow coves that could be readily defended. A first line of defence therefore existed, formidable in itself to any but the boldest foe, before a single shell could be dropped over the walls of the town. Each of these points had now been strongly intrenched, mounted with batteries, provided with pits for riflemen, and protected by the formidable and familiar American method of felled trees laid with their branches outward.

Amherst's army consisted of about 12,000 men, made up of the following corps:-The 15th (Amherst's), 17th (Forbes'), 28th (Bragg's), 35th (Otway's), 40th (Hopson's), 47th (Lascelles'), 48th (Webb's), 58th (Anstruther's), the first and second battalions of the 60th or Royal Americans, and the 63rd (Fraser's Highlanders); there were also five companies of rangers and artillery, with about 140 guns of varying 


\section{8] PREPARATIONS FOR LANDING}

calibre. The Highland regiments had been recently raised by Pitt, to whom belongs the honour of converting the late enemies of the British Government into battalions that were to prove one of the most formidable of its weapons. The Royal Americans, too, whose acquaintance we have already made, were the origin of battalions no less famous in British annals. Most people, I fancy, would be surprised to hear that the 60th Rifles was first raised in America, and consisted not merely of colonists, but very largely of German colonists ; so much so, indeed, that it was found advisable to procure a number of officers from Switzerland and Germany who could speak their language. Their chief, Colonel Bouquet, was a Swiss, an extremely able and accomplished officer, who was now in Pennsylvania with Forbes, and of whom we shall hear later. He has moreover left a journal of his doings in America which is well worthy of perusal.

Boscawen had twenty-three ships of the line and seventeen frigates, and it was the 2nd of June before his whole fleet arrived off the town. A heavy sea was running, and the rugged shore was white with an unbroken line of raging surf. Amherst, however, with Lawrence and Wolfe, the latter still suffering sorely from his dire enemy, sea-sickness, took boat, and rowing along the coast surveyed it through their glasses. There were only three places at which a landing was possible, even when the weather moderated, and these, it was seen, were all strongly intrenched. On the 5th the wind dropped a little, but gave way to a fog, which was even worse. On the 6th both wind and fog moderated, and the troops were placed in the boats; but the wind again increasing, they 


\section{WOLFE LEADS THE ATTACK [1758}

were ordered back to the ships. The sailors, with all the will in the world, thought gravely of any attempt to land. Boscawen sent for his captains one by one, and they were all inclined to shake their heads. A fine old sea-dog, however, one Ferguson, captain of a sixty-gun ship, the Prince, would have no halting, and by his vehemence turned the scale in favour of prompt action. On the evening of the 7 th the wind fell slightly, the night proved clear, and soon after midnight the men were once more dropped into the boats. It had been arranged that the attack should be made in three divisions on three separate points. Lawrence and Whitmore were to threaten the two coves nearer the town, while Wolfe made the actual attack on Kennington Cove or Le Coromandiere, the farthest off, the most accessible, but also the most strongly defended, and some four miles distant from the city.

When morning broke upon the short summer night, all was ready for a start, and at sunrise the entire fleet opened such a furious cannonade as had never been heard even in those dreary regions of strife and tempest. Under its cover the boats pushed for the shore, Wolfe and his division, as the chief actors in the scene, making for the left, where, in Kennington Cove, some twelve hundred French soldiers, with a strong battery of guns, lay securely intrenched just above the shore line and behind an abattis of fallen trees. As Wolfe's boats, rising and falling on the great Atlantic rollers, drew near the rocks, the thunder of Boscawen's guns ceased, and, the French upon shore still reserving their fire for closer quarters, there was for some time an ominous silence, broken only by the booming of the surf as it 
leapt up the cliffs or spouted in white columns above the sunken rocks. Heading for the narrow beach, the leading boats were within a hundred yards of it when the French batteries opened on them with a fierce hail of ball and round shot. Nothing but the heaving of the sea, say those who were there, could have saved them. Wolfe's flagstaff was shot away, and even that ardent soul shrank from leading his men further into such a murderous fire. He was just signalling to his flotilla to sheer off, when three boats on the flank, either unaware of or refusing to see the signal, were observed dashing for a rocky ledge at the corner of the cove. They were commanded by two lieutenants, Hopkins and Brown, and an ensign, Grant. These young gentlemen had caught sight of a possible landing-place at a spot protected by an angle of the cliff from the French batteries. Without waiting for orders, they sent their boats through the surf, and with little damage succeeded in landing on the slippery rocks and scrambling to temporary shelter from the French fire.

Wolfe, at once a disciplinarian and a creature of impulse, did not stand on ceremony. Feeling, no doubt, that he would himself have acted in precisely the same fashion as his gallant subalterns under like conditions, he signalled to the rest to follow their lead, setting the example himself with his own boat. The movement was successful, though not without much loss both in boats and men. The surf was strong and the rocks were sharp; many boats were smashed to pieces, many men were drowned, but the loss was not comparable to the advantage gained. Wolfe himself, cane in hand, was one of the first to leap into the surf. These were not the men of Oswego, of Lake 


\section{FRENCH DRIVEN IN}

George, of the Monongahela, of the Virginia frontier. The spirit of Pitt was already abroad, borne by the very breakers on these wild Acadian shores, and burning in the hearts of these fierce islanders, who, like their Norse ancestors of old, came out of the very surf to wrest dominion from their ancient foe. As the troops came straggling out upon the beach, full of ardour, soaked to the skin, and many of them badly bruised, Wolfe formed them rapidly in column, routed a detachment of Grenadiers, and fell immediately with the bayonet upon the French redoubts. The enemy, though picked and courageous troops, were taken aback, and fled without much resistance. They had seen Amherst, too, with reinforcements, coming up behind Wolfe, and above all had noted the flotillas of Whitmore and Lawrence between them and the city, and were fearful of being cut off should these last effect a landing. The French were pursued over the rocks and through the scrubby pine-woods till the pursuers came within play of the guns of Louisbourg, which opened a heavy fire to cover the retreat. Over a hundred were killed or taken prisoners, while the loss of the British in landing was not much less.

Amherst now traced the lines of his camp along a shallow valley, watered by a small stream, which was not only out of range of the Louisbourg guns, but invisible from the walls. Here he proceeded to intrench himself, erecting blockhouses at extremities where an attack might be expected from Acadians and Micmac Indians, with which the wilderness beyond was thought to swarm. The sea, however, remained so rough that it was some days before the troops could get their tents, stores, and lighter guns on shore. It 


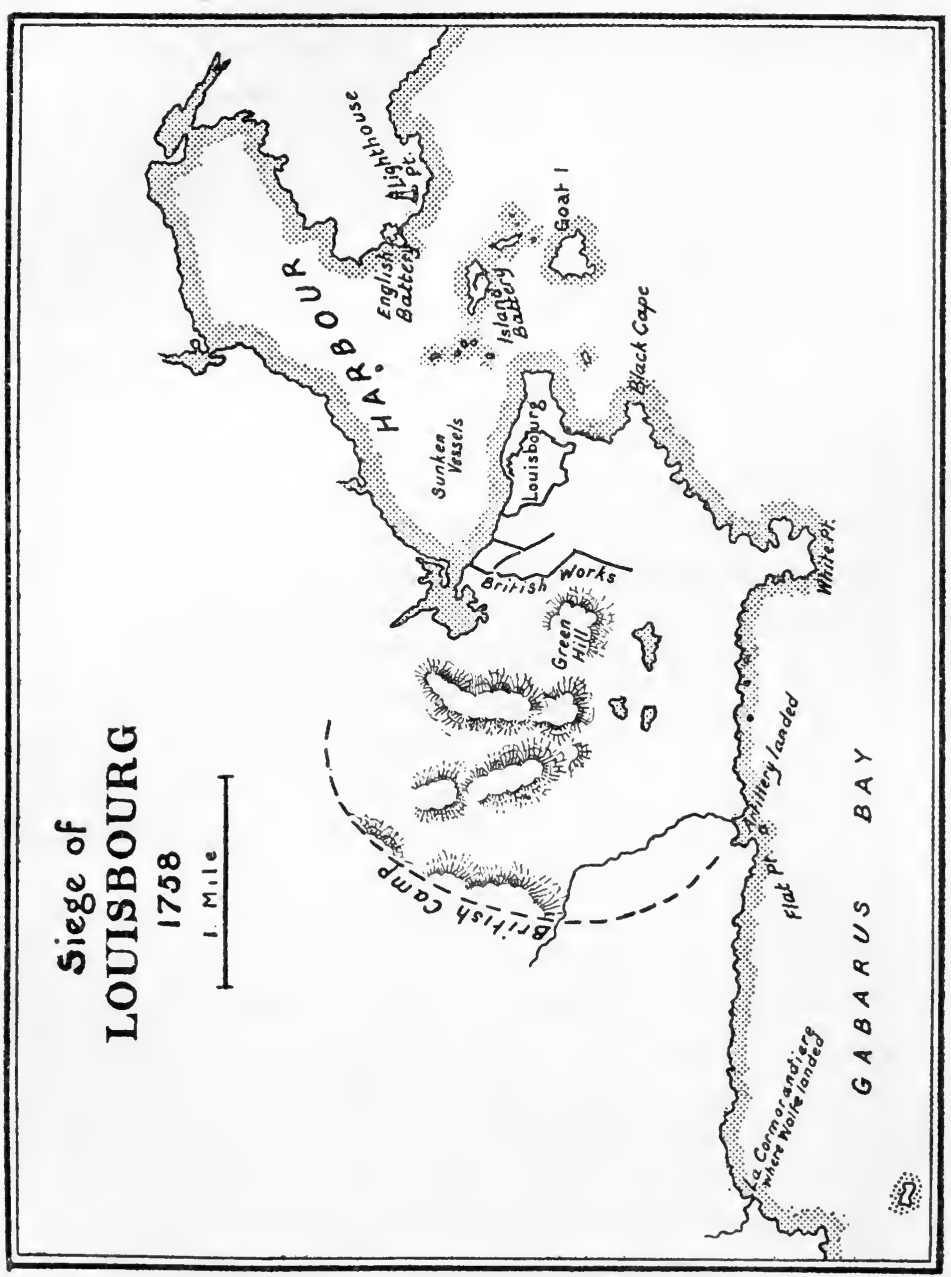





\section{8] WOLFE'S LIGHT INFANTRY}

was not till about the 17th, when the weather moderated, that the siege guns could be brought from the fleet. Both services worked with a will, but their difficulties may be estimated from the fact that over a hundred boats were destroyed in the operation.

The French now drew all their men within the fortifications. A large battery of thirty guns on the opposite side of the harbour, with houses and fish stages, was destroyed by the garrison on the night of the British landing, and a great conflagration reddened both sky and sea. The guns were spiked, as were those of a smaller battery at the eastern point of the harbour's mouth. Wolfe had a large corps of light infantry, picked for their marksmanship from various regiments, and trained, so far as a week or two at Halifax could train them, in tactics that became familiar enough later on, but were regarded at the time as quite a strange innovation on the part of the vigorous and eccentric brigadier. It was merely a matter of advancing in loose formation, and using all the inequalities of the ground for protection, coupled with a light and easy costume for the men, namely a short jacket, small round hat, and a kind of light woollen trouser, cut moderately tight. A story goes that an officer who was regarded as somewhat learned among his fellows remarked to Wolfe that his new

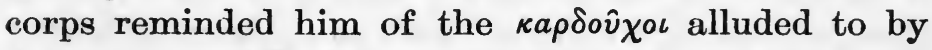
Xenophon. "That is exactly where I got the idea," replied Wolfe; "only these people never read anything, and consequently believe the idea to be a novel one."

Amherst's first move was to send Wolfe with his light infantry on a long, rough march of seven or eight miles around the harbour to erect some 223 


\section{GOAT ISLAND BATTERY SILENCED $[1758$}

batteries upon the farther shore, the necessary guns being despatched by water. In this business, notwithstanding the scantiness of soil and the absence of suitable timber, he was so alert that by the 26 th he had not only mounted his chief battery at Lighthouse Point, but had intrenched all his men in safety from the fire of the town and fleet, which had been fierce and continuous, and furthermore had effectually silenced the formidable French battery on Goat Island in the middle of the harbour entrance.

There was nothing now to prevent Boscawen, if he so chose, from sailing in with his whole fleet, so the French admiral, Desgouttes, rather than lose all his ships, prudently sunk four of them by night in the channel, to protect the rest. Wolfe, in the meantime, had been writing cheery letters to Amherst, telling him of his progress, and greatly jubilant that the French fleet were now "in a confounded scrape." This was precisely what the French admiral and his officers had been thinking for some time, and Desgouttes had urged on the Governor the desirability of getting his ships off while there was yet time. Drucour, however, thought differently, as he wanted the ships and the sailors to prolong the defence, and so prevent the besieging army from either proceeding to Quebec that season, or from helping Abercromby against Montcalm at Lake George. For a fortnight an artillery fire had been steadily proceeding upon the harbour side, while to the westward, where the serious attack was contemplated, Amherst's dispositions were not quite ready, the engineering difficulties being considerable. Wolfe, having done his work, now hurried back to the main lines, which were henceforward to be the chief scene of action. 


\section{8] THE BRITISH APPROACHES}

An extensive marsh stretched away from the walls of Louisbourg on the landward side. Beyond this rolled the rugged, broken ground in which the British intrenchments lay. On each side of the marsh, however, rocky knolls extended up close to the defences of the town. It was along these horns, as it were, that Amherst had to push his batteries under a heavy fire. With rocky hillocks and swampy flats to approach over, Amherst's task was no easy one; but he was distinguished for patience and thoroughness. What he lacked in dash, Wolfe, who by the 27th was back at his side, most amply supplied. Thousands of men toiled night and day, while a hundred big guns roared with tireless throats from the massive works of masonry on the west of the town, and poured shot and shell upon the British working parties as they crept gradually nearer. But the pick, the shovel, and the axe proved as efficient in defence under the skilful eyes of those who directed them as they were to prove formidable in advance, and no serious loss was suffered. A French frigate, the Aréthuse, bravely manned and commanded, was stationed in a western angle of the harbour, where the northern wing of the approaching invaders could be reached, and proved herself extremely troublesome. She stood in her turn a vast deal of cannonading, till at last she was brought off, her shot holes plugged, and running the gauntlet of the British fleet in a fog, she bore safely away, and carried the news of the sore plight of Louisbourg across the Atlantic.

On both the right and left the English batteries were now pushed forward to within half a mile of the town, and, with Wolfe on one side and Lawrence 


\section{SORTIES REPULSED}

on the other, began their deadly work. Two hundred big guns and mortars, plied upon both sides by skilled gunners, shook that desolate coast with such an uproar as no part of North America since its first discovery had ever felt. Twenty thousand disciplined troops, soldiers and sailors, led by skilful and energetic commanders, made a warlike tableau, the like of which had never yet been seen, with all the blood that had been spilled between the Mississippi and the St. Lawrence, while infinite valour animated both sides. On July 6 th, a sortie was made upon the advanced trenches on the British left which was easily repulsed. Three days afterwards a much more serious effort was pressed by a thousand men, stimulated by brandy, the English accounts say, upon the right. The British Grenadiers were forced back out of the trenches, fighting desperately with the bayonet in the dark. Wolfe was here, revelling in the bloody mêlee, and the enemy was ultimately driven back into the town.

At this time, too, the long-threatened attack of Acadians and Indians, out of the wilderness on the left flank, was delivered. They were commanded by Boisherbert, a partisan leader of note, but were easily repulsed, and gave little further trouble.

On July 16th, Wolfe made a rush forward and fortified a small hill, locally famous as the spot where Louisbourg malefactors were executed. It was only three hundred yards from the ramparts of the town, and the artillery fire now waxed terrific.

On both wings, indeed, the British advance was pushed so close that gun after gun was dismounted on the Louisbourg ramparts, and the masonry itself began to crack and crumble in all directions, while 


\section{8] A TREMENDOUS BOMBARDMENT}

British soldiers were pressing forward to the very foot of the glacis, and firing upon the covered way. On the 21st, one of the French ships in the harbour, the Célebre, was ignited by a bomb, and the flames spread to two others. The British batteries on the extreme left commanded the scene, and rained such a hail of balls upon the flaming decks that the ships could not be saved, and all three were burnt to the water's edge. Shells, round shot and bombs were now falling in every part of the devoted town. Nearly all the sailors of the fleet were with the garrison, and all the townsmen who could bear arms helped to man the defences.

There had been a little earlier some friendly amenities between besiegers and besieged. Amherst had sent some West India pineapples to Madame Drucour, whom an uncertain French authority, that one would like to believe, declares took a personal part in the defence. Madame sent back a basket of wine, while Drucour himself offered the services of an exceptionally skilful physician to any of the wounded British officers who cared to avail themselves of them. But matters had got too serious now for such courtesies. On the 22nd the chief house of the citadel, where the Governor and other officials were living, was almost wholly destroyed by fire. A thousand of the garrison were sick or wounded and were cowering in wretchedness and misery in the few sheltered spots and casements that remained. The soldiers had no refuge whatever from the shot and shell. Night and dayfor there was a bright moon-the pitiless rain of iron fell upon the town, which, being built mostly of wood, was continually igniting and demanding the incessant labours of a garrison weakened and worn out by the 


\section{DESPERATE STATE OF GARRISON [1758}

necessity of sleepless vigilance. The gallantry of the defence equalled the vigour of the attack, and was all the more praiseworthy seeing how hopeless it had become. Only two ships of war were left in the harbour, and the British bluejackets, who had been spectators of the siege, now thought they saw a chance of earning some distinction for their branch of the service. So five hundred sailors, in boats, running the gauntlet of the fire from the town upon the harbour side, dashed in upon the Le Bienfaisant and Le Prudent, overpowered their feeble crews, burnt the latter ship, and towed the other one into a corner of the harbour secured by British batteries. The harbour was now cleared of French shipping. Another great fire had just occurred in the town, destroying the barracks that had been an important point of shelter. The bastions on the land side were rapidly crumbling. On the 26th less than half a dozen guns were feebly replying to the uproar of 107 heavy pieces firing at close range from the British batteries, and more than one big breach in the walls warned the exhausted garrison of the imminence of an assault.

A council of war was now called, and the vote was unanimous that a white flag should be sent to Amherst with a request for terms. This was done but when Amherst's answer came, the opinion was equally unanimous against accepting what he offered, which was unconditional surrender within an hour. The officer was sent back again to urge a modification of such hard conditions, but Amherst, well knowing that he had Louisbourg at his mercy, refused even to see the envoy. With singular courage, seeing that no relief was possible, the French officers resolved to bear the 228 


\section{8] SURRENDER OF LOUISBOURG}

brunt of the attack, and Franquet, the engineer who had constructed the fortifications with de la Houlière, the commander of the troops, proceeded to select the ground for a last stand. But the townspeople had no mind to offer themselves up as victims to an infuriated soldiery, for they remembered Fort William Henry, and dreaded the result. The CommissaryGeneral came to Drucour, and represented that whatever might be the feelings of the military with regard to their professional honour, it was not fair to subject 4,000 citizens, who had already suffered terribly, to the horrors of an assault upon that account alone. He pointed out, and with justice, that no stain, as it was, could rest on the garrison, who had acquitted themselves most bravely against a numerous and formidable foe, and his arguments had effect. The messenger, who for some cause or other had delayed in his mission, was overtaken and recalled, and Amherst's terms accepted. These last required that all the garrison should be delivered up as prisoners of war and transported to England. The non-combatants were at liberty to return to France, and the sick and wounded, numbering some 1,200 were to be looked after by Amherst. All Cape Breton and the adjacent island of Saint Jean (now the fertile province of Prince Edward), with any small garrisons or stores therein contained, were to be given up to the English.

On July the 27th the French troops were drawn up on parade before Whitmore, and, with gestures of rage and mortification, laid down their arms and filed gloomily off to the ships that were to take them to England. 5,637 prisoners, soldiers and sailors, were included in the surrender. About 240 sound pieces of 


\section{DEMOLITION OF LOUISBOURG [1758}

cannon and mortars, with a large amount of ammunition and stores, fell into the hands of the victors. The French fleet in attendance was totally destroyed, and French power upon the North Atlantic coast ceased to exist.

With Halifax so near, possessing, as it did, an even better harbour, an already firm British establishment and a good tributary country, there was evidently no need for such a place as Louisbourg. So to place it more entirely out of the reach of all enemies, the British Government decided upon its destruction. Two years after this, in 1760 , a great crowd of workmen, navvies and soldiers, toiled continuously for six months at the task of demolition, and the busy, famous warlike town was in this strange fashion wiped out of existence. Never again could a short sighted English Government, blind to its greater interests, because these were not in the Mediterranean or the English Channel, reinstate by treaty a French garrison in Cape Breton. To-day a collection of fishermen's huts by the shore is nearly all that is left of this great stronghold of French power in the days when a mighty colonial future lay within her grasp. Short by comparison as is the story of the New World, he would be a dull soul who could stand unmoved by that deserted, unvisited, surfbeaten shore, where you may still trace upon the turf the dim lines of once busy streets, and mark the green mounds which hide the remains of the great bastions of Louisbourg. It has not been given in modern times to many centres of note and power to enjoy within the short space of a century and a half at once such world-wide fame and such profound oblivion. 


\section{8] REJOICINGS IN ENGLAND}

\section{CHAPTER VIII}

W HEN Captain Amherst, bearing his brother's despatches, arrived in England with the news of the fall of Louisbourg and laid the captured French standards at the king's feet, the nation, long accustomed to reverses, broke out into a wild frenzy of joy. With beat of drum and flourish of trumpets, the French flags were carried, through crowds of shouting citizens, from Kensington Palace to St. Paul's, and there deposited with a faint echo of the long tempest of artillery which had preceded their capture. The country, too, had just been plunged in mourning by news of the disaster of Ticonderoga which has to be related in this chapter; and the revulsion of feeling accounted no doubt in part for its excessive exultation. Bonfires flared and church bells pealed from John-o-Groat's to the Land's End, while addresses of congratulation poured in upon the king from every quarter. American troops had taken a very small part in this achievement; but if this fact in any way damped the joy of the colonies at a victory which was more precious to them even than to the mother country they did not show it. Each city celebrated the occasion in its own characteristic fashion. Boston by a flood of pulpit eloquence, New York with cakes and ale, and a prodigious amount of toastdrinking, while the peace-at-any-price element of 


\section{'AMHERST GOES TO NEW YORK [1758}

Philadelphia were well content to let the more worldly portion of its community indulge, like the rest, in bonfires and rockets. It was not till long after Boston and New York had completed their rejoicings for the victory, says Captain Knox, that news of it reached the lonely forts upon the western coast of Nova Scotia, where he and his comrades were eating their hearts out among mosquitoes, black flies, and scalp-hunters.

At the fall of Louisbourg, Wolfe was ardent to push on at once to Quebec. Boscawen and Amherst would probably have consented, with such a strong naval and military force at their disposal. It is idle, however, to speculate on what their decision might have been, or what their chances of success, for news had come to Louisbourg as to London, which made it plain that one more "Incapable" had to be removed, before the road to success was cleared of obstacles. Amherst had now to hasten away to New York and to Abercromby's assistance with several regiments, leaving Whitmore in charge of Louisbourg, and Wolfe to ravage the coast-villages of the St. Lawrence gulf, a task he makes wry enough faces over in his letters home.

Pitt had this year appealed to the colonies for a force of 20,000 men, to operate against Canada. The northern provinces, particularly those of New England, had already made great and creditable exertions. Massachusetts was easily the foremost in this spirited competition, and had pledged her credit to the extent of half a million sterling, a heavy burden on her finances, for in Boston the taxes had risen to 13s. in the pound on real and personal estate. Connecticut was but little behind, while the small province of 232 
New Hampshire placed one in three of her adult males in the field. These northern colonies, including New Jersey and New York, replied to Pitt's appeal with an actual force of 17,480 men, 7,000 of whom were supplied by Massachusetts. Poor Shirley had been long recalled, and ill-requited, for his public spirit; not so much, perhaps, because he had made mistakes, as that he had provoked jealousy among rivals even less successful. Governor Pownall now reigned in his stead over the Puritan Commonwealth, and took some steps this year to make the officers of its willing, if not very formidable, militia more effective disciplinarians. When a corps of picked rangers, or woodsmen destined for special service, elected their own officers, the results were excellent; but when the militia of a rural democracy steeped in village politics, followed the same system, it was a very different matter. The notion that a private was as good as his captain, even if sometimes justified by facts, did not conduce to success, in the face of Montcalm's veteran regiments. A great improvement in this particular was now introduced by methods which do not directly concern us here.

Abercromby was at Albany, the inevitable base of all operations, by May 11th, but the usual delays in getting the colonial troops into the field occurred, and they were not all assembled till the end of June. There was always 'a deficiency in arms, tents, and clothing, and it was the remedying of this that, as usual, caused the delay. But, when all was at length finished, the force upon Lake George was not only powerful but in every respect complete, and its chances of success seemed practically assured. It wanted only a general. 
Albany was quite a unique town in colonial America. Mrs. Grant, of Laggan, in her Memoirs of an American Lady, has left us a delightful picture of this home of her youth, at a period corresponding about exactly with the one now treated of. The daughter of a Scotch officer, she was brought up in the household of that very famous colonial lady, "Aunt Schuyler," returning in after years to residence and marriage in her native country. She was advanced in life when she wrote the two small volumes which have been the delight of all students of old colonial life; and this, no doubt, accounts for certain inaccuracies. ${ }^{1}$ When, in the summer of 1758 , the luckless Abercromby gathered over 20,000 regular and provincial troops at Albany, it was still a purely Dutch town. There was a small handful of cultivated aristocratic families, like the Schuylers, owning large estates, fine houses, well furnished with old china, plate, and well-painted pictures brought from the low countries; and there were the numerous burghers of the town, of lower station, and nearly all interested in the Indian trade-simple, kindly, and religious, though by no means austere folk, according to our authoress. Every well-to-do family owned house ne-

1 Dr. Kalm, the Swedish traveller and scientist, who visited Albany more than once about this period, gives a very different picture of the burghers. He declares it was the only place in his wide travels in North America where he was consistently cheated. He says, moreover, that the Dutch traders did not scruple to buy the plunder of ravaged New England homesteads from the Indians, arousing thereby such fierce resentment among the New Englanders that they had more than once threatened to make an example of Albany and its inhabitants. Nor can the Doctor account for the remarkable difference which he describes as notorious between the morals, manners, and habits of the Albanians and the Dutch of the lower country, whom he entirely approves of.

234 


\section{8] DUTCH LIFE IN ALBANY}

groes, whom they treated with the same consideration, and even affection, as the best families of Virginia treated their household servants: "Slavery softened to a smile" Mrs. Grant calls it. The town consisted of one very long street, running parallel with the river, and another meeting this in the centre at right angles, while others less important branched out to the right and left. The houses were even then mostly of brick, their gable ends, built Dutch fashion, fronting the street, and containing the front door with its "stoop," where the family sat on summer evenings, while rows of maple trees rustled by the sidewalk. Every house had a roomy garden and one or more cows, which were driven home at morning and evening from the common pasture-land to be milked. The old dislike of the English had greatly softened among the burgher class, and was practically dead among the patroon set, who went to New York in the season, had an English Episcopal church in Albany, and gave generously, both in blood and money and hospitality, to the English cause, which was, in fact, their own. Three years of military occupation, however, played sad havoc with the Arcadian simplicity of Albany as Mrs. Grant paints it. It was in vain that the heads of households tried to discriminate in their hospitalities between the serious and the frivolous among the officers. The younger generation could not resist the gay, play-acting young ensigns and captains, covered with lace and gold ; and fell into all their strange and dubious amusements with a facility that was deplorable in the eyes of their elders. The Dutch ministers, we are told, after months of pulpit protestations gave up their flocks in despair; and the Puritan traditions of the place-which was now 235 
nearly a hundred years old - were permanently shaken. Indeed, one may well imagine that the social ethics of the second George's reign, turned loose upon a town that, though Puritan, and unsophisticated, possessed much capacity for enjoyment, created a vast commotion. With the army, too, came all sorts of people, officially or commercially engaged in ministering to its wants, and the old burghers shook their heads at this flood of innovation from the outer world. All good people, however, have their failings, and the Puritan variety has been ever inclined to allow himself a special code in the matter of achieving a bargain. The innocent Albanians had carried this to such lengths with the Indians that the shaky attitude of the six nations towards the British was chiefly their handiwork. Lastly, we get vivid glimpses of the great dislike felt by the people of the other colonies, whether English or Dutch, to those of New England. New England, however, may well have been consoled by the fact, that if she was unloved by her neighbours she alone was regarded by the French, in a military sense, with something like respect.

Woodland fighting between the Rangers of both sides was going savagely on, while the more serious warfare was labouring for a start. All the forts upon the Hudson, north of Albany, and those in the valley of the Mohawk were manned, and on the watch. All the notable guerilla leaders, French and British,-men of valour rather than of virtue, most of them-were out upon the war-path. British officers shared frequently in these dangerous ventures, not as leaders having authority, but as humble students in the art of forest warfare, under men like 
Stark and Rogers; and their inexperience not seldom cost them their lives in fights a loutrance, where quarter was neither asked nor given and scalps were a valuable asset.

It was near the middle of June when Abercromby gathered together at Fort Edward the forces he was to lead against Ticonderoga. The site of Fort William Henry was now, as ever, the front of the British position. A stockade had been erected both there and upon the adjoining hill, where the massacre of the preceding year had taken place, and was strongly garrisoned, while the energetic Bradstreet, wisely placed in charge of all the transport, with 800 boatmen under him, had prepared nearly 1,500 craft of various sorts for the passage of the army down Lake George.

Now at last all was ready for the embarkation of the greatest armament that had ever darkened the surface of an American lake. Abercromby had with him, in round numbers, 6,300 regulars and 9,000 provincials, including batteau men. With the former were the 27th regiment (Blakeney's), the 42nd Highlanders, the 44th (Abercromby's), the 46th (Murray's), the 55th (Lord Howe's), two battalions of the 60th (Royal Americans), and Gage's Light Infantry. The hopes of the colonies ran high. They had made great efforts, and never had so large or so well-equipped a force been collected under one command in America. Abercromby was something of an unknown quality, but his organizing powers had given good promise; while Lord Howe, who was with him, had won golden opinions upon all sides, and greatly endeared himself to the colonists. He stood somewhat on the same platform as Wolfe, and was 237 


\section{LORD HOWE}

about three years older. The latter declares, in a letter, that he is " the best officer in the British army"; while Pitt himself is scarcely less emphatic. Howe was, in fact, not only a fine soldier, but was wholly free from the narrow-minded prejudices that made the average British officer tread upon the corns of his colonial brother in arms almost whenever he met him. He was gifted with a precious intuition,--rare now, and much rarer then, - which realized that there might be social excellence outside that focussed in St. James's, and military worth in homespun coats and hunting shirts. He grasped at once the colonial point of view, a result not often achieved under a term of years by Englishmen even in our enlightened day, and was, in consequence, as much beloved by the colonists as by his own men, and they would have followed him anywhere. He admired the Rangers and studied their tactics. He saw that the Englishman was prone to be somewhat heavy, pedantic, and elaborate in his movements, and slow, as he is even now, to seize the often rough-and-ready methods of expediting matters in a new country. He snipped off the long coat-tails of the infantry, browned their shining gun-barrels, cut their hair short, and improved their leg-gear : adding both comfort and speed to the poor fellows' progress through the hot and dense woods. He not only set an example of good manners to his officers in their behaviour to the people of the country, but was rigid in cutting down superfluous baggage, going so far as to wash his own linen and eat his dinner with a clasp knife,as an example to his subordinates. And yet, so mysterious are the ways of Providence, that he was killed by the very first shot fired in an enterprise which some men said depended 



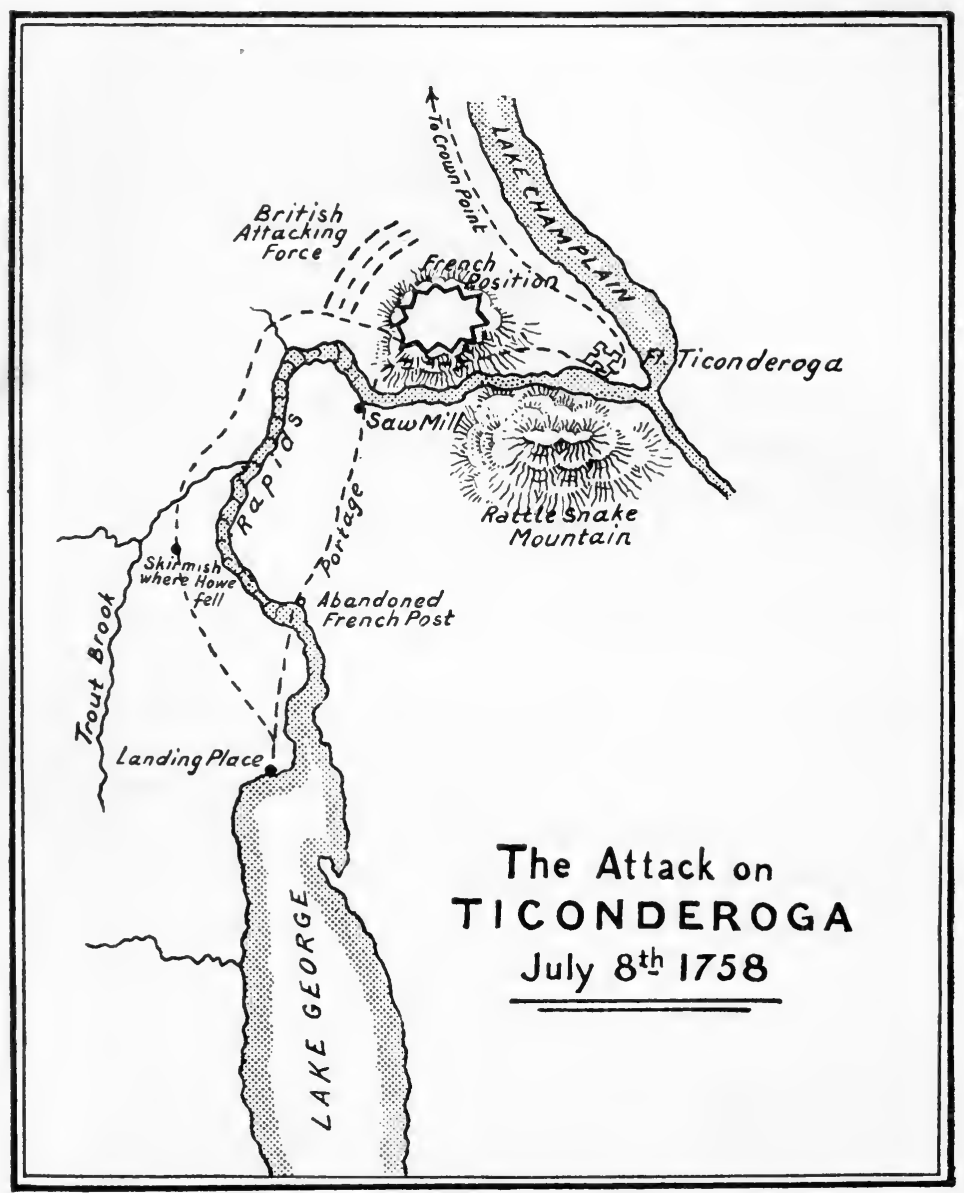


on his leadership. In the meanwhile, a word must be said of what was happening all this time with the French at Ticonderoga.

De Vaudreuil had cherished designs of his own against the Mohawk valley by way of Lake Ontario, and had weakened his none too numerous forces by dividing them. He was anxious, too, about Quebec, in the event of the fall of Louisbourg. Bourlamaque, however, was at the stone fort at Ticonderoga with the regiments of La Reine, Guienne, and Béarn, some Canadian regulars, and a few militia. Montcalm had hurried down there with further reinforcements, comprising the battalions of La Sarre and De Berry. Lévis had been sent westward by de Vaudreuil, but was hastily recalled when even that prodigious egotist admitted that a great crisis was impending. The French force with Montcalm was but little over 3,000 men, though these 3,000 , to be sure, were of the very best.

A reference to the map will remind the reader of the topography of this memorable position. Fort Carillon, or Ticonderoga, will be seen on the point at the head of Lake Champlain, just where the little river, having circled round its eight-mile bend, comes hurrying from Lake George. The middle four miles of this, it will be remembered, were unnavigable rapids, and a road, forming as it were the string of a bow, had been cut from the head to the foot of this shallow water. At the foot of the rapids, whence boats could float into Lake Champlain, and two miles above the fort, was a saw mill and a bridge. Here Montcalm awaited news, sending a force to occupy the Lake George or upper end of the rapids, and a party of 300 into the woods beyond, to report on the 


\section{THE FRENCH ENTRENCHMENTS [1758}

movements of the English. Large as Abercromby's army actually was, its numbers were exaggerated by scouts and Indians, and Montcalm may well be excused if even his stout heart began to sink. French tactics had usually been wise. But this year Montcalm had been over-ruled, and de Vaudreuil outwitted. By every law of human chance Montcalm had only one hope, namely, in retreating as rapidly as he could. But recent experiences had taught him there was one chance not allowed for in the rules of war, and that was in King George's generals, and he boldly decided to count upon it.

He heard that the army had embarked from William Henry, leaving him, therefore, about two days for preparations. He longed for Lévis, who was expected hourly, and, in the meantime, there was much discussion as to the best spot for resistance. The stone fort was voted out of the question, as being too small, and overlooked, moreover, by Rattlesnake Mountain. Crown Point was thought of, but the day advanced, and some definite decision was urgent, in the face of such fearful odds. Bourlamaque and his men had, in the meanwhile, been recalled from the Lake George end of the rapids, where the English were expected to land, and the bridge destroyed. The entire army, officers and men, now set to work, with axe and pick and shovel, to carry out the plan which at the last hour was agreed upon.

Fort Carillon, or Ticonderoga, stood near the point of a high promontory, with the mouth of the river on one side and Lake Champlain on the other. The ridge which formed it ran inland for some distance, leaving a strip of densely wooded swamp on either side, between its slope and the water's edge, and along 


\section{8] EMBARKATION OF THE BRITISH}

this ridge only was it easy of access from the land side. Here, some half-mile from the fort, by the infinite labour of the whole army, and in an incredibly short space of time, was thrown up an intrenchment, impregnable to anything but artillery. The crest of the ridge was lined with a solid wall of tree trunks, piled one above another to a height of eight or nine feet, and traced in zigzag fashion, so that its face could be enfiladed from any point. The ground, even in the front, sloped away, while on the sides towards the marshes it was steep and rocky. For the space of a musket-shot in front, the dense forest had been cut down, the trees lying in tangled confusion as they had fallen. Immediately before the breastwork, and constituting the most formidable barrier of all, layers of large trees had been laid, with their tangled branches facing outward to the foe, twined together, and sharpened at the points. This work was begun upon the morning of the 7 th, and was only just completed when Abercromby delivered his attack, upon the morning of the 8th; Lévis having just arrived with 400 men, bringing Montcalm's force up to 3,600 of all arms.

In the meantime, with such pomp and circumstance of war as had never been witnessed, even from the bloodstained shores of this romantic lake, Abercromby had embarked upon the enterprise which no man thought could by any possibility again miscarry. It was July the 5th, and the very week in which those despairing sorties of the French from Louisbourg heralded their approaching defeat, when the British flotilla crowded out on to the surface of Lake George. The pages of historian and novelist alike glow, when they recall the splendour 241 


\section{A GLORIOUS PAGEANT}

of this notable scene. The faded types of old colonial journals, the yellow tattered letters, written at the time by those who saw it, all testify to the glories of such a pageant as is not often spread before the eyes of men. Many who have never set actual eyes upon Lake George, will have surely visited it time and again with those fascinating companions whom Fenimore Cooper provided for their youthful fancy, will have stood upon its shores with Guert Ten Eyck and Corny Littlepage, or pierced the mysteries of the surrounding forest with the wily Uncas and the resourceful Leather-stocking.

On this memorable July morning twelve hundred boats, laden with troops and munitions of war, stretched like a vast armada across the bosom of the lake. The summer dawn was brilliant and cloudless. The sun had just risen over the mountain tops, and chased away the mists that night had gathered along the swampy shores. Not a breath of air was stirring on the water, not a ripple ruffling the silver sheen of its surface; nor over that illimitable sea of woodland, which swept upwards in successive waves from the island-studded shores, came breeze enough to move a blossom or a leaf. With regular precision, its wings stretching to right and left, and as the narrow lake grew narrower, reaching almost from bank to bank, the splendid pageant swept slowly northwards. In the centre were the British regiments, all gay in scarlet and white and gold. Upon the right and left and in the rear went the colonial troops, in blue and red. In the front was the gallant Bradstreet, with his sailors and axemen, in soberer guise, and Gage's light infantry, with their strange caps and short jackets and moustachioed faces. 


\section{8] LANDING OF THE BRITISH}

From the whole dense flotilla came the glint and flash of burnished arms, and above the boats, at intervals, hung the standards of famous regiments, impatient to inscribe some American triumph on their folds, while the brave show of over a thousand tartans-those of the "Black Watch"-filled in the picture. Ten thousand oars, with measured beat, caught the sunlight; and the bands of various regiments, with their martial music, woke the echoes of the mountains, which, as the lake narrowed, lifted high above it, upon either side, their leafy sides and rocky crests. Many a man went proudly down Lake George that day beneath the flag of England who, twenty years later, was upon this very spot to be found turning his sword against his mother country and his king. Lee was there, a hot-tempered British captain, and, curiously enough, of marked unpopularity among the provincials; Starke and Israel Putnam, too, were present, hardy and conspicuous riflemen from New England frontier farms; and Philip Schuyler, Dutch gentleman and patroon, now leading a New York company, and some day to be Washington's favourite general, and Alexander Hamilton's father-in-law. Now, however, the French peril had crushed out for the moment such germs of future movements as had already, in vague fashion, taken root. With France upon her flanks, the very existence of New England depended, whether she liked it or not, upon the mother country.

Landing for a few hours at Sabbath Day Point, twenty-five miles down the lake, the men re-embarked again at dark; and, pressing onward 'through the summer night, reached the foot of the lake at ten on the following morning. Montcalm's outposts had 243 


\section{DEATH OF HOWE}

been withdrawn from here, and the bridge over the outflowing river destroyed. The British landed, therefore, without opposition; and, leaving the boats under a strong force, prepared to march down the left bank of the connecting river. Headed by Lord Howe and his light infantry, the whole force, the English in the centre and the colonials on the flanks, moved forward through a country, not only densely timbered, but encumbered with the wreckage of fallen trees. The men forced their way through the dank tangled bush in such order as they could, till it became evident that some one had blundered, and that the column was hopelessly astray. Suddenly from the front came the sound of firing. It was the 300 men that Montcalm had sent out to feel the English advance, under his partisan captain, Langy. The denseness of the forest, and the darkness of the preceding night, had been too much even for Langy's guides, and the contact was one of pure accident upon both sides, The surprise was mutual, and was followed by two hasty volleys. It was Lord Howe's rangers and light infantry that were engaged, and that gallant nobleman fell dead at the first discharge, shot through the heart. We must not concern ourselves with what might have happened but for this luckless shot in a petty skirmish, which resulted in the death or capture of nearly all Langy's men, or whether Howe's influence would have averted the catastrophe that has to be related. It is enough to say that his fall was greeted with a wail of grief throughout the army and the colonies. Mrs. Grant, so often quoted, tells us how Madame Schuyler, at whose hospitable country house, near Albany, Howe, like most of the principal officers, had spent 244 
much time, received the news : "In the afternoon a man was seen coming on horseback from the north, galloping violently, without his hat. The man galloped on, crying out that Lord Howe was killed. The mind of our good aunt had been so engrossed by her anxiety and fears for the event impending, and so impressed by the merit and magnanimity of her favourite hero, that her wonted firmness sunk under this stroke, and she broke out into bitter lamentations. This had such an effect on her friends and domestics that shrieks and sobs of anguish echoed through every part of the house." Wolfe, while before Louisbourg, writes "if the report of Howe's death be true, there is an end of the expedition, for he was the spirit of that army, and the very best officer in the king's service." Even Abercromby, in his official report, notes the universal outbreak of grief caused by his death. In Westminster Abbey may be seen a monument, somewhat unique in its origin, erected by the Government of Massachusetts, to the memory of George, Lord Viscount Howe, etc., " in testimony of the sense they had of his services and military virtues, and of the affection their officers and soldiers bore to his command."

The army, baffled by the nature of the country on the west bank, and the want of guides, had to bivouac in the woods on this night, the 6th, and return in the morning to the landing-place. A day of infinite value had been lost, but this Abercromby could not know. He determined now to take the rough but direct and beaten road on the east bank of the stream and re-build the bridge, which Montcalm had destroyed, re-crossing the river again at the farther end of it, near Ticonderoga. The invaluable and active 245 


\section{POSITION RECONNOITRED}

Bradstreet was therefore pushed forward with a strong force on the morning of the $7 \mathrm{th}$, and rapidly restored the broken bridge.

Abercromby, with the main body, came up in the evening, and camped at the saw-mill for the night. He was now less than two miles from the intrenchment at Ticonderoga which Montcalm was busy finishing. He had left such guns as he had, and on which hinges a vital question, at the landing-place, six miles back. In the morning Abercromby sent what most historians, with unconscious but misleading grandiloquence, call his "chief engineer," Mr. Clerk, to report on the French defence. On this also hangs a tale. Mr. Clerk seems to have been merely a subaltern " commissioned sub-engineer and lieutenant, January 4th, 1758." ${ }^{1}$ He had therefore been just six months in the service. The poor young man, happily perhaps for himself, died the next dayone of the victims of his own inexperience or rashness. One may well wonder at the system which left the safety of an important army to the judgment of a half-taught youth. It is bad enough to find Wolfe, as a then unknown and untried boy of sixteen, adjutant to his regiment at Dettingen. But this seems even worse.

In the thick forest there was only one spot from which the French position could be reconnoitred, and that was Mount Defiance, just across the mouth of the little river, within a mile of their intrenchment. It was from the top of this eminence that Clerk examined the formidable breastwork of hewn logs girdled with the chevaux de frise of fallen trees in the midst of the tangled clearing, and decided that

1 See Kingsford. 
they could be carried by assault. Abercromby's information was to the effect that 6,000 Frenchmen were here, and more coming, which we know was inaccurate. He was therefore in a hurry to attack. He had left his guns at the landing-place; having brought them thus far apparently for the purpose of covering his landing in case of the opposition he expected, but, as we know, did not encounter. He now decided, on the strength of Clerk's report, to attack Montcalm's intrenchments, which, by the way, contained some artillery, with the bayonet. This initial error might have been forgiven. But that when it became apparent, it should have been persevered in at such frightful cost, is unforgiveable and unforgetable. Most of the officers of that force seem to have been of the type whose mission was to enjoy themselves in peace, and in action to get themselves killed cheerfully, without criticising the tactics of their commanders. Moreover, few had seen the redoubt. There appear to have been a few dissentient voices on this occasion, probably from those who had, but they were not too insistently raised. The colonists, many of whom knew the district well, may have wondered at the tactics of the British general ; but every one's blood was up, and the business at Fort William Henry had left a burning desire for revenge. "I think we were all infatuated," wrote a young officer, describing the scene by letter to Captain Knox, in Nova Scotia. Lord Howe was dead, and the brain of the army was paralysed. The pity of it all lay in the fact that Abercromby had left his guns at the landing-place, whence they could have been fetched in a few hours.

From Mount Defiance he could then have pounded 


\section{THE BRITISH FIX BAYONETS [1758}

the huddling mass of Frenchmen within the intrenchment at will, or knocked their defences about their ears in an hour; for they were not strong enough to venture an attack. They had only a week's provisions, and were nearly 200 miles from their base. Even if no artillery had been available, the British general, with his 15,000 men, could have surrounded them, and starved them out without firing a shot. There were several alternatives, all practical certainties, and probably bloodless ones; and Montcalm knew this when, on the sole chance of having a blunderer in front of him, he staked his all on this forest ridge at Ticonderoga.

It was high noon, and a blazing sun poured its rays vertically down on the front ranks of the British columns as they moved out of the forest into that mass of tangled branches, through which they were to fight their way. The Rangers and light infantry, who had been pushed forward to drive in Montcalm's outposts, fell back on either flank as the long red lines of Grenadiers, supported by the Highlanders of the "Black Watch," over a thousand strong, all with bayonets fixed, stepped out of the shadow of the woods into the fierce sunlight. Their orders were simplicity itself : to go forward, namely, at the charge, and not fire a shot till they were within the ramparts. From the top of Mount Defiance, where Abercromby's cannon should have been stationed, 400 friendly Indians, who had just arrived with Sir William Johnson, to share the British triumph, looked cynically down with shaking heads and many deep guttural ejaculations of contempt. It might be magnificent, but it was not war according to their notions of the game, and they 248 
absolutely refused to throw their lives away in any such midsummer madness.

It is a lamentable tale that has now to be told, and one of tragic monotony. Forcing their way through the tangled chaos of tumbled trees, the front lines of British infantry pressed on as best they could, with orders to carry by steel alone those bristling barriers behind which over 3,000 Frenchmen lay invisible and secure, with levelled muskets. As the British approached the abattis of prostrate trees, laid outwards with pointed branches, a sheet of smoke and flame burst from the eight foot log breastwork which lay behind it, and a fierce storm of bullets, mixed with grape shot swept through the advancing ranks. In vain the survivors of that withering discharge tried to force their way through the dense network of opposing boughs, and reach the foot of the wooden wall beyond. Some acquaintance with backwoods life would help the reader to more thoroughly realize the hideous nature of such an obstruction, when alive with bullets fired by a highly disciplined and protected enemy at a distance of twenty yards. The hopelessness of the task must have been obvious to any observer; but Abercromby either did not or he would not see it. It is said that he remained most of the time near the saw-mill, over a mile away, though no imputation is cast on his personal bravery. All that remained for his soldiers was to obey his orders, and to dare and die, which they did with splendid and piteous gallantry.

The order to withhold their fire, however, was soon treated by the troops with the contempt which, under the circumstances, it deserved; but this availed them little. Here and there the head of a French- 


\section{THE BUTCHERY OF TICONDEROGA [1758}

man showed above the rampart, as he stood on the raised platform to fire; and now and then an English bullet found its mark above or between the logs. A battery of artillery would have knocked the rude defences into splinters in an hour, but to bayonet or musket ball they were hopelessly impregnable. Regiment after regiment struggled desperately on against that fatal barrier; but as each rush of men strove to tear their way through the immovable frise of branches, it was met by a storm of lead, such as no troops could face and live. As each shattered column fell sullenly back, leaving a fearful tribute of dead and wounded, fresh ones came rolling on like the waves of a sea, and to break as surely at the foot of that flaming parapet. Thus went on the futile heroism and the useless slaughter. Gay young officers, whose routs and plays had so lately been a fearful joy to the simple folk of Albany, hung quivering corpses amid the fast withering leaves of the interlacing trees. Here and there a Highlander, mad with fury and contemptuous of life, had actually sealed the log wall and leaped down to certain death among the enemy. Many are the tales that have come down to us of deeds of personal heroism performed upon that bloody day; but where all were heroes it matters less that there is no space for them. Now and again there was a lull, born of sheer exhaustion, the smoke lifted from the deadly clearing, and men may well have looked for some word from their sphinx-like general; but Abercromby gave no sign, except, with imperturbable fatuity, to persist in his mad course. Fresh troops were ordered forward, and with them returned to the charge the survivors of the last attacks. There was no sign of hesitation 
throughout the whole of those terrible four hours, and never was greater gallantry shown in an effort so lamentably superfluous.

"It was in vain at last," says Warburton, " as it was at first; and upon that rude barrier, which, the simplest manœuvres would have avoided, or an hour of well plied artillery swept away, the flower of British chivalry was crushed and broken."

"The scene was frightful," writes Parkman; " masses of infuriated men, who could not go forward and would not go back, straining for an enemy they could not reach, and firing at an enemy they could not see."

It was within a day of being the third anniversary of Braddock's defeat, and, as on that fatal field, the full heat of the hottest period of the American summer simmered in the smoke-charged clearing, which even the warm lake breezes could not reach. It was five o'clock, and nearly four hours of this insensate work had not daunted the spirit of these gallant men. For it was at this moment that the most furious onslaught of the whole day was made upon the French right. Then, and then only for a few brief minutes, was Montcalm's position in danger, and he had to hurry in person with a strong support to where a group of Highlanders, with superb indifference to death, were making their way up and over the parapet. But the gallant effort was fruitless. It was the last of the succession of furious attacks to which Montcalm does full justice, marvelling in his heart at the madness which inspired them, and welling over with gratitude at his good fortune. One or two more half-hearted and despairing attempts were made upon the deadly lines, when the 


\section{THE DEATH ROLL}

General, recognising at six o'clock what he should have seen at one, gave the order to retire. Then amid some desultory firing of colonials and Rangers, from the bordering forest, the shattered British regiments fell back to the saw-mill, whither the wounded had been previously conveyed in batches, and those yet to be gathered from the battlefield were subsequently taken. The French had done enough. They were as exhausted with the great strain of their victory, as they were exalted, and made no attempt to molest the retreat, and the British army spent that night in peace at the saw-mills. Burning both mill and bridge, they then marched the six miles to the landingplace, and there embarked, with sad hearts and boat-loads of wounded, on the very spot where, two days before, they had landed in all the pride and confidence of anticipated victory. One hears sometimes of a certain amount of panic accompanying this retreat, but there seems no direct evidence to this effect, and it is entirely against reason, though Abercromby did believe there to be 6,000 Frenchmen inside the barricade, and that reinforcements were close at hand. As a matter of fact, the French fully expected another attack; but Abercromby, though he had still over 13,000 men behind him, abandoned all thought of further action, and put his large force again into camp at his base on the head of Lake George.

It now remained but to count the cost, and this was frightful. Very nearly 2,000 men had fallen in a short quarter of a summer day, and the greater part of these were of the 6,000 regulars, who had borne the chief part of the affray. 300 provincials only figure in the returns; but no half-disciplined militia, without bayonets, however brave, could have 


\section{8] AN INCIDENT OF THE FIGHT}

been launched upon a task so obviously hopeless. For sheer intrepidity, however, the "Black Watch" must bear off the palm on a day as memorable for individual heroism as for concrete failure. This fine regiment, "every one of whose soldiers," says a contemporary writer, who knew them intimately, "considered himself as raised somewhat above the rank of a common man," went into action over 1,000 strong, and came out 499 . The French loss was under 400, though de Bourlamaque was seriously, and de Bougainville slightly wounded.

There were some other incidents in the battle, but they pale into insignificance compared with the sustained frontal attack. The strips of densely wooded swamp on either side of the intrenchment were guarded by Canadians and Indians, and Abercromby's provincials made several futile attempts to dislodge them. Bradstreet, too, had brought some batteaux over land from Lake George, and these were filled with riflemen and floated on the river, in the flank of the French position; but cannon were brought to bear on the crowded boats, to their complete discomfiture, two or three of them being actually sunk. In the heat of the frontal attack there occurred one of those misunderstandings, or worse, that is strangely suggestive of operations proceeding at this very moment in another continent. A captain of the Royal Roussillon regiment tied a flag to the end of a musket, and waved it towards a British column in the act of attacking. The latter took it as a sign of surrender, and, crossing their muskets on their breasts, with their muzzles in the air, stepped innocently forward towards the abattis. The French troops on their part, and, of a truth, with unaccountable simplicity, if it be true, 


\section{CAMPBELL OF INVERAWE}

regarded the action of the British as denoting surrender, and they ceased firing, preparatory to receiving them within the breastwork. Whether the waving of the flag was an instance of that "slimness" for which the South African Boer is noted, or was merely a meaningless and sudden impulse on the part of the French captain, is uncertain. But another captain (Pouchot), who tells the tale, describes how he arrived on the scene at this moment, and saw the English line advancing and the French standing quietly awaiting them with grounded arms. Knowing nothing of what had gone before, he shouted to the French soldiers to fire, or the English would assuredly capture them. A volley was then delivered, which, according to the same officer, killed or wounded about 200 of the unsuspecting British. There was great indignation at the time among the latter, but it seems probable that no bad faith was intended. A famous legend, too, surrounds the memory of one of the victims of this bloody field, and must by no means be overlooked.

It so happened that a certain Duncan Campbell, of Inverawe Castle, was at this time a major of the "Black Watch." Some years previously, and before the regiment was raised, so runs the story, he chanced to be sitting alone at midnight in the hall of his old castle, when suddenly there came a knocking at the gate. Going out himself he found a blood-stained Highlander, worn and torn with travel, who confessed to having killed a man in a fray, and to being closely pursued by officers of the law, and entreated the laird to give him shelter and protection. The latter consented, but the fugitive was not satisfied till Campbell had sworn secrecy on his dirk, which he somewhat 
rashly did. He had scarcely hidden him away, when there was a fresh hammering at the castle gate, which proved to be the avengers of the law on the fugitive's track. These informed Campbell that his cousin Donald had just been murdered, and that the murderer was somewhere in the neighbourhood. The laird was greatly perturbed, but, remembering his oath, professed to know nothing of the matter. That night, as may well be supposed, sleep did not come readily to his eyes, and before long was effectually banished by the dread presence of the murdered man, who suddenly appeared at his bedside, and in a sepulchral voice addressed him thus: "Inverawe! Inverawe! blood has been shed; shield not the murderer."

Campbell was so horrified, that the next day, though he would not break his oath, he refused any longer to keep the guilty fugitive beneath his roof, but took him out to the hills, and hid him in a cave. This, however, would not suffice to lay the ghost of his murdered cousin, which appeared to him again the next night, repeating the same significant injunction. Campbell, distraught with superstitious fears, hastened at dawn of day to the mountains; but the cave where he had hidden his unbidden guest was empty - the murderer had flown.

Once more, on the following night, the ghastly vision stood by Campbell's bedside. Its attitude was not so menacing, but its words were perhaps yet more significant: "Farewell, Inverawe; farewell, till we meet at Ticonderoga."

Now at that early time, neither Campbell nor perhaps any other British officer, had so much as heard the name of the obscure backwoods post; so he marvelled greatly what this strange arrangement 


\section{DEATH OF CAMPBELL}

of letters might mean, and for this very reason it remained indelibly imprinted on his mind.

Two or three years afterwards the 42nd was raised, and in due course ordered to America, and, as we have seen, became part of the force operating against Ticonderoga, which till then had been usually known by its French name of Carillon. When Duncan Campbell first heard the strange word that had lain half dormant but unforgotten in his mind for years, and that he was to attack the place which it signified, he gave himself up for lost; and though a valiant soldier, succumbed to the mental depression which a strong presentiment is apt to produce on superstitious natures, however brave. His brother officers tried by various ruses to make him think it was not actually Ticonderoga they were about to attack. But on the morning of the 8th-the fatal day-he remarked gloomily to those about him that it was idle attempting to deceive him, for that very night he had again seen the apparition, which on this occasion had uttered but three words : "This is Ticonderoga." "And this day," said the major, "I shall fall." Fall he did, and was carried wounded to Fort Edward, on the Hudson, where he shortly afterwards died. His grave may yet be seen, and on the stone above it may be read: "Here lyes the body of Duncan Campbell, of Inverawe, Esq., Major to the old Highland Regiment, aged 55 years, who died the 17th July, 1758, of the wounds he received in the attack of the Retrenchment of Ticonderoga or Carillon on the 8th July, 1758."

We must pass over the justifiable exultation of the 3,000 and odd brave Frenchmen who stood that day so staunchly behind their log breastworks, the 


\section{8] A HALF-FORGOTTEN TRAGEDY}

letters that were written, the pæans that were sung, the triumph that resounded throughout France and Canada, to say nothing of the inevitable exaggerations that went out concerning an achievement that indeed required none. Montcalm, when he heard of Louisbourg, expressed a wish that his Ticonderoga heroes had been there. But in so doing his pen ran away with him. He did an injustice to his equally brave troops in Cape Breton, and forgot for the moment that a single half-battery of Amherst's guns would have blown his wooden ramparts into fragments, and that he owed his triumph, and even his own safety, to a blunder, that he must have well known was outside every calculation of war.

Such was Ticonderoga, the least remembered, though one of the bloodiest, most desperate, and most dramatic battles of our history, at once a glory and a shame. The schoolboy has never heard of it; the journalist, who in these stirring times is called upon to summarise the triumphs and defeats of byegone days, seems often in like plight. Thackeray's Virginians is probably responsible for much of the recollection that survives of the Monongahela, though Braddock had not nearly as many men in action as fell at Ticonderoga. Cooper was not so fortunate in fastening upon the public mind that Homeric contest on Lake Champlain; which was, perhaps, the most humiliating reverse we ever suffered at the hands of the French, and a fight that, save for Burgoyne's surrender, far overshadows any of the numerous conflicts fought in that historic region. For yet another generation was to wake the echoes of these noble solitudes with a strife as bitter, and on an issue only less momentous than this one. It is a popular 


\section{AN HISTORIC LAKE}

impression that North America is barren of associations, that its natural beauties lack the atmosphere of history, legend, and tradition. It is not so much the lack of these, as the lack of equipment to appreciate them, that is at fault. He would be a callous wight indeed, who, thus equipped, could stand upon the shores of Lake George, and feel no thrill but what its physical features awakened. If eighteenth century life be accounted sufficiently remote to appeal to the historic fancy,-which it surely is, - think with what infinite picturesqueness, with what fulness of romance, its quaint figures, its stirring pageants grouped themselves upon a canvas, in itself so exquisitely fair. Not once or twice, as a fleeting vision, but year after year passed backwards and forwards the motley martial throng: frilled and powdered dandies of the second George's time, in scarlet, and lace, and gold; no less punctilious exquisites from the outer circles, at least, of Louis XV.'s brilliant Court, long-skirted, gaitered, pig-tailed soldiers in red or white, from Devon and Yorkshire villages, from the orchards of Normandy, and from the slopes of the Pyrenees. Fair-haired Germans and hardy Switzers were here; keen soldiers of fortune some, others simple hirelings; savages, too, of tribes innumerable, in bark canoes, all painted and be-feathered with the immoderate profusion of those primitive days; wild, bearded, lion-hearted Rangers, in fringed hunting shirts and coon-skin caps, and masses of hardy, Godfearing rustics in blue or homespun, from Connecticut and Massachusetts farms.

The very contrasts, in a country that has lived at double speed, gives the past a greater aloofness and a stronger fascination; and never surely 


\section{A MODERN CONTRAST}

was war more picturesque than here. It is not much more than a century since the last cannon shot was fired, and the last actors in the final scene, that of the revolutionary war, passed from the stage. Yet what an age, however, in this new world, it seems, and how vast the change! These ancient battle-fields are now the playground of an abounding population, from teeming cities that were then but trifling villages or frontier forts. The beauty of lake and mountain and forest is still here. The grey ruins of Ticonderoga may yet be seen, mouldering amid the throb of modern life. But villages and hamlets and huge hotels, gay with holiday-makers, cluster on the shores. Steamers and pleasure-boats ply joyously along the bays and through island channels, where of old scalp-hunting Indians and Rangers crouched for their prey amid the rocks and reeds. The engine screams along the banks, now smooth by comparison, and long shorn of the tangled wilderness, where redcoats blundered into ambushes, and even the ranger was sometimes at fault. But beneath the wheels of panting trains, or the hurrying feet of careless tourists, and sometimes, perhaps, even yet, amid the murmur of pine and hemlock woods, there sleep unnumbered and forgotten dead-French and English, colonist and Indian, Dutch and German, who fell here when the fate of America was yet hanging in the balance, and its greater portion still lay wrapped in the silence of unbroken forest or untrodden prairie. 


\section{INDIGNATION AGAINST ABERCROMBY}

\section{CHAPTER IX}

DITT took the disaster of July the 8th sorely to 1 heart. His friends endeavoured to console him by pointing out the valour and the spirit which had animated the soldiers, even to the last moment of their hopeless attempt; but the failure, summed up in facts and figures, was outside consolation. Happily the news of Louisbourg followed so quickly on that of Ticonderoga, that both Pitt and the British people, save those who mourned their dead, were soon buoyed up again on the high tide of hope. Loud was the outcry in America against the hapless Abercromby, as he sat down again, at the head of Lake George, with his 13,000 men, raised, fed, and transported at such pains and cost. He has since had his defenders for thus retiring, after so severe a rebuff, on his base of supplies; but to all the critics in his own army, whose views survive, it seemed sheer poltroonery. The 9,000 provincial troops who had been conveyed to the scene of action and brought back again almost intact, sounded the loudest note of indignation, save, perhaps, that of the provincial taxpayers. The General, however, does not seem to have suffered from an over sensitive temperament, and he quietly set about intrenching his front, upon the site of Fort William Henry; and without any apparent sense of humiliation, exchanged his former rôle of 


\section{8] INACTION ON LAKE GEORGE}

an irresistible invader of Canada to that of the defender of a threatened frontier. His army, no doubt, thanks only to himself, was greatly shaken in morale, but it was still enormously superior to that of Montcalm, who could not believe that he would be left unmolested. As time passed on, however, and it became evident to the French that no attack on Quebec by Amherst was likely, men were crowded down to Ticonderoga, and before the commander-in-chief was free to support Abercromby, Montcalm had troops enough and intrenchments enough to make his eviction a matter of such serious difficulty that all thoughts of it were given up. The doings of Abercromby and his disheartened men this autumn need not detain us. They occupied the old lines of defence and communitation from Lake George across the fourteen mile carrying-place to Fort Edward, and thence down the scattered forts upon the banks of the Hudson. A single sloop, flying the British flag, and carrying six of the guns which had made that incompleted pilgrimage to Ticonderoga, cruised about Lake George undisputed mistress of that mimic sea.

The passing of provision convoys from port to port, for the use of Abercromby's inactive army, gave Montcalm's Rangers, slipping up Wood Creek from Lake Champlain into the British country, fine scope for their energies, while Rogers and Putnam, with their equally hardy and daring followers, were as active as their rivals, both in defence and attack. But the military machine as a whole remained immovable upon the lakes. Amherst's men, to the number of 3,000, landed at Boston from Louisbourg in September, and made a long march across the grain of a rough country to Fort Edward. It was too late, however, even 


\section{BRADSTREET}

in Amherst's opinion, seeing the great strength of the French, to make another attempt on Ticonderoga; and we may now leave the camps on the New York frontier to an autumn season of discontent. Gathering snowstorms and freezing waters in due course put an end to their unprofitable labours, and sent them into winter quarters to glean what consolation they might from the better fortune of their comrades at Louisbourg, and in two other quarters which must now be dealt with.

Before consigning poor Abercromby to the oblivion which ensued upon his recall-the best fate, indeed, he could have hoped for-it should be said to his credit that he consented to a scheme, and supplied the troops for it, which was entirely successful, and materially helped the triumph at Louisbourg to counterbalance the disaster on Lake George. Bradstreet, whose acquaintance we have already made, was the hero of the enterprise. He was a New Englander, had served as a captain in the former war, and as lieutenant-colonel of provincials had done yeoman's service in this one. In the management of batteaux, whaleboats, and canoes, and of the men who manned them-a vital department of these campaigns-he had no rival. He was, moreover, a brave and enterprising soldier equally at home in the forest, in the open plain, or on the surging rapid. He was somewhat contemptuous of European generals and their deliberate tactics, but was on good terms with all the British commanders, and greatly valued by them, as indeed he may well have been, for he was of infinite service to the British cause. He received a royal commission, and died eventually a Major-General in the English army. If the gratitude of a country is 262 


\section{8] EXPEDITION AGAINST FRONTENAC}

to be estimated by its biographical literature, it has forgotten Bradstreet, as it has forgotten many another man, who laid his country and his race under a lasting debt in the wild woods of eighteenth century America.

Bradstreet had for a long time kept his eye on Frontenac, that important half-way station between Montreal and the remoter western forts. It was a depôt of supply, too, for these, as well as for the new garrisons in the Ohio valley. He had urged Loudon in the preceding autumn, when his operations had all failed, to let him make a dash upon this vital French position, but Loudon was nothing if not cautious, and had refused. Poor Abercromby, however, grasping at anything which promised some mitigation of his affairs, listened readily to the renewed applications of Bradstreet, after the failure at Ticonderoga, and gave him 3,000 men, all of them from the provincial militia except 200 regulars, and 300 batteau men, and 70 Indians. Bradstreet had got word that Frontenac was denuded of its usually strong garrison, which. had been withdrawn by Vaudreuil to strengthen the only part of Canada now supposed to be in danger, namely, that threatened by Abercromby's army.

Bradstreet's only line of attack was of course up the old western route, by the Mohawk valley, to the site of the vanished Oswego, on Lake Ontario. Up this long toilsome track by lake, rapid and portage, the New England colonel and his batteau men pressed their way with ready and familiar steps, the colonial soldiers marching none the less cheerfully, though suffering much from sickness, that they were under one of their own leaders. They passed General 


\section{CAPTURE OF FRONTENAC}

Stanwix, who was busy erecting the great fort at the Oneida watershed that was to bear his name, and on the 22nd of August stood beside the ruins of Oswego, looking out over the blue waves of Lake Ontario, to the shoreless horizon, behind which lay the still virgin forests of Western Canada. Great numbers of Bradstreet's soldiers had dropped behind from sickness, but he had written Abercromby that if he had only a thousand left he would carry out his venture. $\mathrm{He}$ had much more than a thousand, though, as it turned out, he hardly needed even that much. Launching his batteaux and whaleboats upon the lake, he had, in four days, landed his men and guns within sight of Fort Frontenac, and on the following morning had a battery mounted within point blank range of the enemy's walls, and the garrison at his mercy. The great French station, key of the west, master of Lake Ontario, and feeder of the Ohio forts that had been for so long decimating the English frontier, had indeed been caught napping. Resistance was hopeless, as a few discharges of artillery soon made evident. There were only a hundred men in the fort, with their women and children, and they promptly surrendered; but it was crammed with stores. The prisoners were allowed to go to Montreal on parole, on the understanding that their equivalent in British captives should be forwarded to Albany. The Commandant was one Payan de Noyan, an aged gentleman of family and considerable culture, but of greatly impaired means, the recuperation of which was indeed the immediate cause of his exile in the backwoods; for it will be remembered that a Canadian fort was given to favourites, or deserving officers, for this dubious purpose. 
This gallant old versifier and scientist, for he was both, heard of Bradstreet's intentions, at an early date, from friendly Indians, and resented being thus caught like a rat in a trap. Vaudreuil, in answer to his earnest solicitation for troops, sent him one man as an adviser, and he with but one arm! Upon which de Noyan, for there was yet plenty of time, begged to be relieved of his honours. Vaudreuil put him off, insinuating, at the same time, that his nerve must be failing. After the inevitable surrender, Vaudreuil bade him be of good cheer, and neither to worry himself, nor take the trouble to draw up formal reports, for that he would explain the whole matter to the court of France. Vaudreuil, who was, in fact, wholly responsible for the fall of Frontenac, did explain matters, but after his own characteristic fashion, giving the king to understand that age had impaired de Noyan's energies; in short, that he had played the coward. The poor old gentleman, who, if he did plunder his king, could not rest under the imputation, certainly an unjust one, of being backward in fighting for him, went to France and craved for a hearing, but to no purpose. Perhaps it was a just judgment on his peculations, though Vaudreuil seems hardly a fitting instrument for Providential chastisement. Thus was Canada governed in her hour of need, and indeed for a very long time previous to it.

The booty taken and destroyed at Frontenac was very great, and the loss to the French, they themselves declared, was worse than that of a battle. There were nine vessels, carrying over a hundred guns, most of which were burned, together with the fort itself, and everything inside it that could not be moved. Sixty pieces of artillery were carried 
away, besides an immense amount of valuable furs, stores, and provisions, valued at nearly a million livres. Bradstreet, to crown the honour of his achievement, refused any share in the booty, his portion being divided among his troops.

It should be remembered that the base, or the Canadian side, of the triangle, on which the whole conduct of this war necessarily ran, was a line along which movement was, for the most part, easy, namely, the St. Lawrence river. The two routes of attack, diverging from Albany, on the other hand, were, as we know, full of obstacles. The French could move comparatively swiftly and without fear of molestation along their line of defence. Hence the prestige earned by Bradstreet in traversing the Mohawk route with such destructive expedition and taking them by surprise. Three thousand Frenchmen had started from Montreal at the last moment, but had only reached the Lachine rapids when they heard that Frontenac, like its old rival Oswego, was no more. Later on there was some slight attempt made to restore it, but misfortunes soon crowded thick on the French, and the spot was ultimately abandoned to the wilderness, which for a generation held its tangled fields and blackened ruins in its grip. Thirty years later a band of refugee loyalists, expelled by force, or urged by patriotic fervour, from the new republic of the United States, gathered at the old Fort of Frontenac, drew lots for the newly surveyed lands around it, and founded the province of Upper Canada, better known to-day as Ontario. The important lakeside town of Kingston now covers the site both of the old French warehouses and batteries, and the fresh wheat and turnip fields of the United 266 


\section{8] RECALL OF ABERCROMBY}

Empire loyalists; it has always been, and appropriately so, the headquarters of Canadian military life. Oswego, its old opponent across the lake, has gone through no less of a transformation. Covered with streets and squares, and flanked with leafy villas, it is a place of much repute, and in addition to its attractions, which are considerable, is famous throughout the world wherever men eat biscuits.

"Frontenac is a great stroke," wrote Wolfe with much enthusiasm when he heard of it. "An offensive, daring kind of war will awe the Indians and ruin the French."

Bradstreet had, as a matter of fact, struck awe into the Indians in the very nick of time, had Wolfe, far away at Cape Breton, only known it. The fall of Louisbourg had influenced them but little; it was too remote. Ticonderoga, on the other hand, had shaken the fidelity of the Six Nations so seriously that Bradstreet found evidence to show that they had never before been so near a wholesale defection to the French. The capture of Frontenac had effectually put a stop to this. It had also destroyed the source whence Fort Duquesne, whither we are now bound, drew its stores and ammunition, and greatly contributed to its fall.

Abercromby was recalled in November, and Amherst took his place as commander-in-chief in America. It was some twenty years later, in the gloomy period of the Revolutionary War, that North uttered his memorable wail, "I don't know whether the enemy are afraid of my generals, I only know that the very sound of their names makes me shiver." George the Second up till now might well have anticipated the sentiment of his grandson's minister; but 


\section{FORBES AND HIS COMMAND [1758}

a change was coming. The Loudons, the Abercrombys, the Webbs, and the Sackvilles, disappeared for a time to crop up again, in another generation and in a slightly altered form, upon this very ground. In the meantime, we must turn south and see how Forbes fared in his arduous march across the Alleghanies to Fort Duquesne.

John Forbes was a Scotsman, of Petincrief in Fife. He received his first commission in the year 1710 , and must therefore have been some sixty-four years of age. He had been colonel both of the Scots Greys and the 17th foot, and was now, with the rank of brigadier, eminently qualified in all respects but age perhaps and health to justify Pitt's choice. He had been a year in America, and in April arrived at Philadelphia with much the same task before him, though better equipped for it, as had confronted Braddock three years previously when bound for the same goal. Of regular troops he was to have the 62nd, or Montgomery's, Highlanders, 1,260 strong, a battalion of Royal Americans (60th), 363, and 4,350 provincials. He had not, however, got them yet. Indeed, Forbes had not only to play the soldier and the organizer, but the diplomatist as well, having to haggle and wrangle with the Pennsylvania burgesses, while they, on their part, seized the opportunity of military requirements to re-open the old congenial squabble touching the taxation of the Penns.

Now Forbes was a man of liberal and enlightened views. It is admitted on all sides that he had none of the hauteur and superciliousness in his treatment of the provincial officers that distinguished so many of his contemporaries, and worked such infinite and 268 


\section{8] PROVINCIAL OFFICERS}

far-reaching mischief; he was regarded, moreover, by all classes with profound respect. His comments, therefore, on the fashion in which the middle and southern colonies went about releasing themselves from the clutch of the enemy and provided for their future development, will be above suspicion. Pennsylvania made a really heroic effort, and out of a population of 260,000 provided 2,500 men. Maryland, which was in the line of attack, with a population of near a hundred thousand, and a social order based on the ownership of slaves and land, contributed 270 very indifferent soldiers. Virginia surpassed herself, and gave Forbes two regiments, comprising in all some 1,400 men.

Forbes, admittedly a cool and impartial judge, was extremely dissatisfied with these levies. Of discipline they were all impatient, and only a portion of them had any qualities wherewith to make up the deficiency. Numbers of them came with damaged firelocks bound up with string; some had not even this much, but walking sticks only with which to oppose the French! "Their officers," said Forbes, "except a few in the higher ranks, are an extremely bad collection of broken inn-keepers, horse-jockeys, and Indian traders." Where, again may be pertinently asked, was the southern chivalry, the sons of the betterclass planters and squires? Washington had, no doubt, been vainly asking this question for the last two years on the war-torn borders of Virginia. Now, when he joined Forbes with his increased regiments, he may well have asked it again. Virginia and Maryland had been far more cruelly scourged in their western districts than Natal, at this moment of writing, and by a still ruder and incomparably more cruel 


\section{APATHY OF THE BETTER CLASS [1758}

foe. The supremacy of the Anglo-Saxon in North America was as clearly the issue of the struggle as it is to-day in South Africa. Yet scarcely a dozen men of birth and character came forward to fight out of two whole colonies, whose numerous gentry was their pride and is still the chief burden of their reminiscent literature. Even if two or three or four dozen such just men could be produced, in the face of the social statistics of these provinces, it would scarcely modify the situation. As I remarked in a former chapter, -and the strangeness of the matter must be my excuse for mentioning it again,- neither love of country, nor thoughts of their murdered countrymen, nor the ordinary martial ardour of youth, nor the prospect of a well-organized and well-led campaign against their two implacable enemies, seem to have had the least effect in drawing the Virginians and Marylanders from their comfortable homes. With such men as we are told formed the bulk of the fifty or sixty commissioned officers from these colonies, it is not surprising that Washington stood a little on his dignity, and intimated at headquarters that he would "gladly be distinguished from the common run of provincial officer," whom he goes on to characterize as " a motley herd." The rank and file were poor men, more lawless and less tolerant of discipline and of a lower social stamp than the men of the New England regiments. Some of them were admirable bush fighters, but others were of no use at all, which was natural enough, seeing the varied districts and occupations from which they came, and the various motives which caused them to enlist.

Forbes had for his chief colleagues: Bouquet, the able Swiss officer who commanded the Royal 
Americans : and Sir John Sinclair, who had been with Braddock as quartermaster-general and was to be so again, though generally disliked and not overcapable. Montgomery was in command of the Highlanders, while Washington and two experienced and tried Virginia soldiers, Colonel Byrd and Major Lewis, the latter then and afterwards a famous Indian fighter, represented the provincials.

Now arose a sharp controversy as to the best route to Fort Duquesne. Braddock's road started, it will be remembered, from Fort Cumberland on the Potomac, and here Washington with his Virginians was now quartered. But the Pennsylvanians and the whole interest of that colony were in favour of cutting a new road which would make the actual wilderness part of the march only 90 miles instead of 122 as before. This difference of opinion was heavily biassed, too, by other considerations. Braddock's road, rough as it had been at the best, had fallen into disrepair, but it was the outlet of Virginia trade to the West, or was expected to be, and the gorge of intercolonial jealousy rose at the notion of the Pennsylvanians having a direct route cut for their traders at the expense of the British Government. This, I need hardly say, was not one of the arguments openly put forward upon either side. These were, indeed, numerous and admirable, and to their respective advocates seemed conclusive, though we need not enlarge upon them. It will be sufficient to remark that Washington, probably from sincere conviction, strongly championed the Virginian side of the question, and predicted disaster if the alternative route was followed; while Forbes and Bouquet inclined to, and ultimately adopted, the Pennsyl- 


\section{THE PENNSYLVANIA ROUTE [1758}

vania scheme. In justice to Washington, it should be added that he promised to render all the assistance in his power whether his advice were taken or rejected.

The dispute and ill-feeling, however, between the two colonies ran very high, and added greatly to Forbes' troubles in providing transport, guns, and provisions. Philadelphia was a far different kind of base from the plantation villages upon which poor Braddock had to lean, and Pennsylvania, though as a colony conspicuously pacific, was eminently businesslike, and comparatively well supplied with the necessities of life and industry. Lastly, it was urged that a new road might spring a surprise on the French at Fort Duquesne, as indeed de Lévis tells us it actually did, though the surprise was not effective.

Bedford, then called Reastown, was the advanced base of action. Thence by the new route, which crossed no large rivers as did the other one, it was ninety miles to Duquesne. But every yard of it was rough, and it climbed the same ranges as Braddock's road, somewhat to the northward, and if anything at more difficult points. Advanced parties were sent forward to make the road under cover of redoubts, and Forbes' plan was to erect these at intervals, so that he could strike his final blow with a permanent chain of posts in his rear, and obviate all risk of that unparalleled stampede of over a hundred miles which made Braddock's disaster so memorable.

It was not till the end of July that the route was definitely decided upon, and Bouquet then went forward to superintend the road-making.

But with all his energy the progress of the Swiss officer was abnormally slow, for there were 6,000 


\section{8] FORBES AT CARLISLE}

men this time to convey across the Alleghanies, with guns and ammunition, and an immense transport. Virginia, too, though incapable of furnishing supplies and whose better people would not fight, was nevertheless raging at the favours supposed to be shown to Pennsylvania. The latter certainly exhibited little gratitude for them, according to Forbes, who thus writes to Bouquet:-

"I have seen with regret this some time past a jealousy and suspicion subsisting on the part of the Virginians, which they can have no reason for, as I believe neither you nor I value one farthing where we get provisions from, provided we are supplied, or interest ourselves either with Virginia or Pennsylvania; which last I hope will be damned for their treatment of us in the matter of wagons and every other thing where they could profit by us, as from these impositions, although at the risk of our perdition."

Carlisle was the village to which the Indian war of the last three years had thrust back the Pennsylvania frontier. Here Forbes remained during August, prostrate with the illness that was soon to kill him, and managing matters in the rear to the best of his ability, while Bouquet, far in advance, hewed his slow way over mountain and through swamp. Matters progressed wearily, but surely. First came the news of Louisbourg, and shortly after that of Frontenac, to cheer the workers. It only now remained for them to achieve a third triumph on the Ohio, but the country offered great difficulties to the engineers, while at the same time, an idea of permanency for the road and its defences had always to be kept in view. A post called Loyalhannon, nearly fifty miles short of Fort Duquesne, was the halfway station 


\section{GRANT SENT FORWARD}

around which events now circulated for many weeks. The French Indians in front began, at this point, to get troublesome and aggressive, and Major Grant of Montgomery's Highlanders made a proposition to Bouquet that was unfortunately accepted, though the gallant and impetuous officer's experience of backwoods warfare was of the slightest.

The whole method of Forbes' advance through the wilderness was to make such progress only as was consistent with security. The object for which Grant was running this risk is not very obvious, and one is only surprised that Bouquet allowed him to take it. His idea was to make a reconnaissance of the fort and ascertain by capturing stragglers or other means what force there was inside it. But Forbes' plans, if once he got there, supported as he was by so large a following, were calculated to succeed in the face of any force at all likely to be present, and the British had provisions for three months.

However that may be, Grant started from the advanced camp at Loyalhannon early in September with 750 men-Highlanders, Royal Americans, and a picked body of provincials under Lewis. They reached the high ridge looking immediately down upon the fort upon the 13th without adventure, after night had fallen. From the same spot to-day a vast arena of belching flame, the smoke, the tumult, and the din of a second Birmingham, would greet the eyes of the spectator; but Grant and his men looked dimly down through forest trees and saw only the feeble lights of a lonely fortress, the broad sheen of the Monongahela, and elsewhere a wide world of shadowy woodland beneath a moonless but starlit sky. 
So far there was great uncertainty as to the strength of the garrison. Indians had told Bouquet that it was at least equal to that of the British. Grant, however, had conceived the notion that it was a mere handful of five or six hundred men. Grant, as it so happened, was nearer the truth, and a week or two sooner would have been nearer still; but reinforcements had quite recently arrived, and there seem to have been now some fifteen hundred men within the ramparts, besides Indians encamped without them.

De Ligneris, whom we have met before, was in command, and de Vaudreuil seems to have imagined, thanks, of course, to his personal exertions, that the fort was secure from all attack. About two in the morning, Lewis, with a detachment of Virginians and Highlanders, was ordered down into the plain to attack the Indians, supposed to be encamped before the fort, and then feigning a retreat, to draw them out to an ambush where Grant and the rest of the party were to give them a warm reception.

Lewis was an accomplished frontiersman and belonged to a well-known fighting family of the Virginia border, one of the few men after Washington's own heart; but on this occasion he got into sad trouble. Grant and his men waited in vain for the sound of his attack, and at last, as the first streak of day was showing, the Highland officer was thrown into a state of rage and consternation at the return of the whole party, who had lost their way amid the woods and fenced enclosures which surrounded the fort and fallen into hopeless confusion. Half Lewis' force were Highlanders new to bush fighting. If Grant had sent the pick of the provincials with him, the 275 


\section{FORT DUQUESNE}

result perhaps might have been otherwise; but it is not likely in any case to have been substantial, for Grant had underestimated the garrison, and still continued to do so. One object of the expedition was to sketch the fort, but the fog at dawn was so thick as to disconcert for a time plans of any kind. Presently, however, it began to clear, and Grant, still under the impression that the French were too weak to venture a serious sortie, made his dispositions.

From the ridge where the British were posted they could see the Alleghany on their right and the Monongahela on their left, sweeping to their confluence immediately below and in front of them. In the angle of the meeting rivers, whose mingling waters thenceforth became the Ohio, stood the famous fort and the numerous rude buildings within and without its lines. The half-mile or so of flat land on the hither side was cleared, fenced, and partly cultivated to the edge of the descending ridges, which were clothed with forest. It was now about seven o'clock, and Grant, retaining a few of his own regiment with him, despatched his Highlanders under Captain Macdonald to take post in the open on the left front of the fort, and a hundred Pennsylvanians on the right. Lewis he sent back with some Royal Americans and Virginians to reinforce Captain Bullitt of the latter, who, with fifty men, was guarding the baggage about a mile to the rear. Lewis had orders to stay there as a support for the attacking party in case of need.

The French all this time appeared to be unaware of the presence of an enemy ; so Grant, by way of stirring them up to the reality of the fact, proceeded to blow lively airs upon his bugles. He soon found that he had aroused them to some purpose; for while the 
Highland officers were busy sketching the fort, French and Indians, to the number of seven or eight hundred, came pouring out of it, some of the former in their hurry not having even stopped to dress. Their attack was directed against the Highlanders, who, reinforced by Grant, made for a time a gallant stand, the Pennsylvanians having retired with some precipitancy into the woods. Fresh bodies of French came crowding out of the fort, till Grant's vanguard was in great distress, being attacked upon all sides. Captain Macdonald and other officers were killed, and the soldiers were forced back into the forest, where for nearly an hour they maintained the unequal fight. At last they could hold out no longer ; it was their first fight in woods ringing with the horrid clamour of Indian warfare, and when they did give way it was in a wild panic, as Grant himself admits. His only hope now lay in Lewis, who was stationed, as he thought, with Bullitt behind the wooded ridge. But Lewis had heard the battle raging, and on his own responsibility had pressed forward to Grant's aid. Unhappily he took a different route in his advance over the ridge to that which Grant followed in his quick retreat, so when the latter reached his base, hotly pursued by the enemy, he found to his horror no support there but Bullitt and his fifty Virginians. Here they were surrounded, and made a final and gallant stand. Grant refused to retire. "My heart is broke," he cried; "I will not survive this day." He was recognised by the French, who called to him repeatedly by name to give himself up; but the rash and luckless officer continued to fight till he was almost alone, when he was disarmed and captured alive. The small band of Virginians with Bullitt fought 


\section{GRANT'S FORCE OVERWHELMED [1758}

heroically, and were all killed except such as escaped by swimming the Alleghany river. Lewis had in the meantime run into the very jaws of the French, and he was also made prisoner. Nearly three hundred men were killed, drowned, or taken. The remaining four hundred and fifty straggled back to Loyalhannon with a precipitancy that after all, when once they had started, was the only sensible course, since fifty miles of shaggy wilderness lay between them and their next meal.

Forbes, stretched upon a bed of sickness at Reastown, and with troubles enough already on hand, received the news like the chivalrous gentleman he was, and called no names, when many and hard ones might well have been looked for by Grant, who was solely responsible. In a private letter to Bouquet, however, he permitted himself some little indulgence this respect. "My friend Grant most certainly lost his wits, and by his thirst of fame brought on his own perdition and ran great risk of ours."

In October, while the British column still lay at Loyalhannon, de Ligneris advanced against it in considerable force. He was not strong enough to actually face the British guns and intrenchments, but he caught several stragglers and destroyed numbers of cattle, and caused Bouquet infinite annoyance. Washington, who had been at Fort Cumberland, at the other end of Braddock's road, all this time, with the other Virginia regiment, now joined the army and took command of the provincials.

Autumn on the Atlantic slope of North America is of all seasons the most stimulating and delightful. Rain, as a rule, falls sparingly or in short spells, and nature, decked in a raiment gorgeous beyond dreams, 


\section{8] DIFFICULTIES OF THE MARCH}

and rarely ruffled by storm or tempest, slumbers in balmy silence beneath an azure sky. Poor Forbes, like Washington, upon nearly the same ground four years earlier, encountered, and in an even worse degree, one of those climatic exceptions that prove the rule. Rain fell persistently, and fell in torrents, while premature snow-storms filled his cup of misery to the brim. On the lower grounds the new-made road was impassable with liquid mud; on the mountain slopes the torrents swept it away as fast as it was made. Forage began to get scarce and the horses became poor and weak. The prospect, lately so hopeful, seemed now well-nigh desperate. Bouquet laboured hard, against the warring elements, the miry swamps, the torrent-riven mountains, and with transport horses growing daily weaker. Forbes, whose indomitable will, rather than improving health, had forced him on to the soaking misery of Loyalhannon, still gave his orders in person. Tortured with pain, and scarce able to stand, he would listen to no suggestions of abandoning the attempt or of himself returning to those comforts which were his only chance of life. It was now well on in November, and some of the Virginian officers, presumably the best authorities, declared further progress to be impossible, and showed such strong feeling that Forbes, unsupported by any following to speak of, called a council of war. The officers who composed this were good and tried men, and they were practically unanimous against any further advance But Forbes, though a sobered and middle-aged soldier, had something of that inspired obstinacy which distinguished another and a greater, but a younger invalid, whom we have met at Louisbourg, and shall meet again at Quebec. Happily for 


\section{FORBES' UNCONQUERABLE SPIRIT [1758}

the country and for the dying general's reputation - though posterity has cared little enough for that - he got news at this moment of a reduction in the garrison of the fort and that the Indians were deserting it. This settled the matter so far as Forbes was concerned, and he gave orders for twenty-five hundred men to be quickly picked from the army for a rapid march, each man to carry a blanket and a few days' provisions.

Forbes' courage in urging a forward advance when men like Bouquet and Washington were against it, thoroughly deserved this piece of fortunate news, which made success so much more probable; nor was it by any means mere good luck, for oddly enough the causes that were thinning the defenders of Fort Duquesne were due in great part to this indomitable officer's precautions in the preceding summer. He had then strongly urged that the western Indians, who had so long been ravaging the frontiers of Pennsylvania and her Southern neighbours, under French instigation, should be approached by diplomacy as well as arms. The Indian was a good deal influenced by his stomach; the side that fed him best scored at least one very strong point, and the French were even thus early finding it necessary to husband their supplies. Spies and scouts brought news that discontent was already showing in the French camps on the Ohio. Forbes had a notion that these savage warriors, who ate bullocks by the hundred and drank brandy by the bucketful, might be detached from their patrons, now that the bullocks and the brandy were getting scarce, and that hints of British beef and perhaps British rum might save much bloodshed both in the army and on the frontier. The provincial authorities 
thought lightly of the scheme, and moreover grudged the expenditure. They regarded such suggestions as the theories of an Englishman without experience of savages. Nor, indeed, was it easy to find an ambassador to cross the Alleghanies, and run the gravest risk of death, and that by horrible torture, in the Indian villages, where English scalps were hanging by hundreds on the wigwam walls. Forbes, however, gained his point, and a man was found who would face the fate that seemed inevitable, and that, too, without reward. This hero was a Moravian missionary, and a German, Post by name, a simple, pious person, but intimate with Indian ways and languages and married moreover to a converted squaw.

Post reached the Ohio villages in safety, and was received with tolerable civility; but his hosts insisted on taking him to Duquesne, that the French might also hear what he had to say, As his ostensible mission was to wean the Indians from the French alliance to those peaceful paths of which his order, the Moravians, were the chief exponents, it was not doubtful what the French would say, and little less so what they would do. As he was the guest of their allies, they had to listen to Post, and did not venture to kill him openly; but behind every thicket they had an agent waiting to take his life, a large reward being privately offered for his scalp. With indomitable courage Post braved the whole thing out, and, wonderful to relate, with impunity. He had succeeded in persuading the Indians to send some delegates, at any rate, to a grand conference near Philadelphia, had shaken their allegiance to the French, and withal, though not without many hair-breadth escapes, got safe back again to civilization. A great meeting was 


\section{APPROACH TO FORT DUQUESNE [1758}

held during the early autumn, presided over by the Governor of Pennsylvania, to which Johnson brought delegates of the Six Nations from the Mohawk and whither also went some of the chiefs of the hostile Indians of the West. With much ceremony and a prodigious wealth of oratory, it was resolved that the Ohio tribes should bury the hatchet with the Six Nations, which was a step at least in the desired direction. Once more the brave Moravian faced the Alleghanies, and again harangued the Indian allies of France under the very eyes of the French themselves, and with such effect that the latter had to submit to the open insults of barbarians they could not afford to offend. Post again escaped safely, having done most valuable work, which was greatly aided by the scarcity of provisions, a condition due to Bradstreet's brilliant stroke at Frontenac, the source of their supplies. So after an alliance of three years, a record of hideous and ceaseless slaughter, the Ohio Indians fell away from the French at the very moment when the gallant Forbes was pushing forward to reap the fruits of his earlier policy, that unknown to him had succeeded almost beyond hope. Swung on a rude litter between two horses, he was led in the van of his flying column through the snow and rain and falling leaves. The army moved in three divisions with caution and in open order, guided through the thick forest by the monotonous tapping of their own drums, which were beat without ceasing at the head of each company. Thinly clad, and with a single blanket to cover them at nights, the men pressed cheerily forward through the mysterious mazes of the woods, till on the 23rd of November the guides had brought them within twelve miles of the fort. 


\section{8] THE FORT EVACUATED}

Here the unexpected news was received that it had been abandoned. They halted a day to confirm the report, and on the 25th moved forward to find the backwoods fortress, so long the curse of British America, standing, silent and deserted amid a fringe of fire-scorched ruins, and the unburied corpses of their own Highlanders who had fallen in Grant's attack. Thus fell, without a protest from rifle or cannon, the very stronghold and hope of French empire in the West, and the scourge of the British frontier.

It seems that de Ligneris, the French commander, had, some time before this, formed the opinion that an attack upon him was impossible before the following spring. His Indians, as we know, had deserted, and, fearful of his provisions running short, he had furthermore dismissed all his troops but three or four hundred, who would suffice for the winter garrison. But he had not long taken this step when he heard that Forbes was in truth coming, and no great way off. He had then no choice but to abandon the post, doing what damage he could do it before leaving, and throwing its guns into the river.

It now only remained to make the fort good for the reception of a winter garrison, and to re-name it. The heroic Forbes had entirely collapsed from the fatigue of the march, and for some days his life was hanging in the balance. Once again, however, the strong will conquered, and he was carried out among his men to superintend their operations. A new and suitable name for the conquered fortress was not hard to find, and Duquesne became Fort Pitt, after the great minister, whose spirit had here, as everywhere, been the source of British triumph. Colonel 


\section{BRITISH GARRISON DUQUESNE}

Mercer, with some Virginians and Pennsylvanians, was left in charge of the fort, and, towards the close of December, Forbes, stretched upon his litter, was borne feet foremost in the midst of his remaining troops on the weary homeward journey through the freezing forests. Though his weakness and his sufferings grew worse rather than better, his mind at least, was now at ease. His task was accomplished, and Ticonderoga was the only failure of the year. The French were driven from the West, their connections between Canada and Louisiana severed, their prestige with the Indians broken, and the demon of Indian warfare on the Alleghany frontier apparently laid. That all this might have been achieved the next year or the year after, is no answer to the decisive nature of Forbes' work. There might have been no next year or year after for military achievements in America. Peace in Europe was at any moment possible. Events there might take a sudden turn that would make boundary lines in the American wilderness appear to most men a secondary matter. Pitt cherished no such illusions now; his intentions to drive the French from America were fixed and clear. But circumstances at home might weaken his arm; or he might die, for his life was none of the best, and it was of vital import that every stroke should be driven home before a general peace was made. A French garrison anywhere in America would have been hard to move by diplomatic means, when once the sword was sheathed.

There was great rejoicing in the middle colonies at the fall of Fort Duquesne, as there had been in New England at the fall of Louisbourg, and for much the same reason, since each had been relieved of a 


\section{8] DEATH OF FORBES}

neighbour whose chief mission had been to scourge them. In England the news was received with profound satisfaction. There was no bell-ringing and there were no bonfires. There had been nothing showy in the achievement, and its import was hardly realized. The glory belonged to two men, and their patient heroism was not of a kind to make a stir in the limited press of the period. But the cool fearlessness of Post was a rarer quality than the valour which faced the surf and batteries of Louisbourg, and the unselfish patriotism of the invalid brigadier was at least as noble a spectacle as that of the Highlanders who flung themselves across the fiery parapet at Ticonderoga.

It was nearly 300 miles from Fort Duquesne to Philadelphia, and Forbes did not arrive there till January 14th. Through all the wilderness part of the march, men had been sent on each day to build a rude hut with a stone fireplace for the dying general. One night, says an officer, some muddle had been made, and the unfortunate Forbes was reduced to insensibility by waiting in the bitter cold for fire and shelter to be provided. It took some time, says the writer, to bring him back to life again with the aid of cordials. He lingered a short time after reaching Philadelphia, where he expired early in March and was buried in Christ Church with military honours. The place of his grave has been obscured by alterations and lost sight of, as may with equal truth be said of his services and his unselfish valour in the memory of his fellow-countrymen.

A melancholy incident occurred while the troops were engaged in repairing the fort. No Englishmen had stood on the scene of Braddock's defeat since its 


\section{SCENE OF BRADDOCK'S DEFEAT [1758}

occurrence three and a half years previously, so a party now proceeded up the Monongahela to visit it, among them being the brigade major, Halkett, whose father and brother, it will be remembered, fell dead together at the same moment. The victims had of course never been buried, and the ground was found plentifully strewn with bones, picked clean by wolves and buzzards and partly hidden by the withered leaves of four successive autumns. Halkett's immediate object was the faint hope of finding and identifying the remains of his relatives, with the details of whose death he was familiar from the report of those who had seen it. Two skeletons were found close together under a tree, at the spot where Sir Peter and his son had fallen, one of which Halkett identified beyond a doubt as that of his father, from a peculiarity of the teeth, while the well-known manner of their death practically marked out the other one as his brother. It was a gruesome spectacle for the survivor, and it is no discredit to the young officer, nerved though he was to bloody scenes, that he broke down at the contemplation of it and, as we are told, "swooned away."

Pitt had good reason to be satisfied with the results of the year's fighting in America. The attack on the French centre had failed, but that upon both flanks, which Louisbourg and Duquesne may fairly be called, had been crowned with victory, while the destruction of Frontenac went to swell the triumph. French prestige with the Indians outside their own missions had been destroyed, the formidable alliance shattered, and all thoughts of further aggression from Canada laid at rest. It now remained to strike at the heart of Canada a deadly blow, which would wither and 


\section{8] THE END IN SIGHT}

dry up those distant sources of wealth and influence to herself and annoyance to her foes, which stretched far away beyond the northern lakes and to the verge of the distant prairies. 


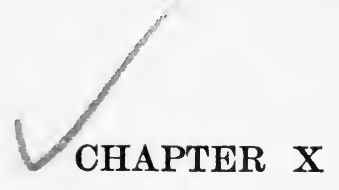

MATTERs had gone well, too, for Pitt in Europe, 11 where he had shrewdly fed the senseless strife of nations with money rather than with men. France, with over 100,000 troops in the field, was playing the somewhat inglorious part of an ally to her hereditary foe Austria, and with the further aid of Russia, was engaged in a fruitless attempt to crush the heroic Frederick. She had now been driven back across the Rhine, after a short occupation of Hanover, by Prince Ferdinand acting with Pitt's direct support. Both her troops and her generals in this reckless war fell far short in skill and spirit of their handful of compatriots struggling for a weightier issue across the sea. The King of Prussia held out against his legion of foes, and was performing prodigies of valour, amid fearful scenes of carnage. At Zorndorp, where with 35,000 men he encountered and repulsed 50,000 Russians, no quarter was asked or given, and 31,000 men fell; while at Hochkirchen Frederick himself lost 9,000 in a single day against the Austrians. In odd hours snatched from the fury of the strife, this extraordinary man still wrote verses and lampoons; but Madame de Pompadour and her miserable Louis were now smarting under something worse at the hands of the Prussian than his caustic pen. England rang with his triumphs, and, by a perversion pecu- 


\section{9] BRITISH CONFIDENCE UNDER PITT}

liarly British, the scoffing freethinker became the "Protestant hero" in both church and taproom. Pitt was omnipotent in Parliament; only a single insignificant member ever ventured to oppose him. "Our unanimity is prodigious," wrote Walpole. "You would as soon hear a "No' from an old maid as from the House of Commons." Newcastle was supremely happy among jobbers and cringing place-hunters under the full understanding that neither he nor his kind trespassed within the sphere of foreign politics. The estimates had exceeded all former limits, and reached for those days the enormous sum of $12 \frac{1}{2}$ millions. The struggle with France was vigorously waged too upon the ocean, warships, privateers, and merchant men grappling to the death with one another in many a distant sea, while the main fleets of the enemy were, for the most part, blockaded in their ports by vigilant British armaments. Everywhere was exhilaration and a superb feeling of confidence, engendered by incipient successes, and by the consciousness that the nation was united in purpose, and that the leaders of its enterprises were no longer chosen because they were "rich in votes or were related to a Duke."

James Wolfe had certainly neither of these qualifications, and he it was who Pitt designed to act the leading part in the coming year, "a greater part," he modestly wrote after receiving his appointment, "than I wished or desired. The backwardness of some of the older officers has in some measure forced the Government to come down so low. I shall do my best and leave the rest to fortune, as perforce we must when there are not the most commanding abilities. A London life and little exercise disagrees with 


\section{WOLFE'S APPOINTMENT}

me entirely, but the sea still more. If I have health and constitution enough for the campaign, I shall think myself a lucky man; what happens afterwards is of no great consequence."

Wolfe had returned from Nova Scotia the previous October in the same ship, strangely enough, with the hapless Abercromby. As the chief hero of an exploit which had sent all England into transports of joy, it is significant that he went quietly from Portsmouth to his regiment at Salisbury, and encountered some difficulty in getting leave of absence on urgent family matters. Even yet a brilliant soldier without backstair influence got scant consideration in his private concerns, while a military cypher with friends at Court could do almost what he pleased. Wolfe, however, eventually got away, and hurried to Bath to "patch up his wretched constitution" for any service he might be called upon. It was here in December that he received and accepted Pitt's offer of the command of an expedition against Quebec. He had just become engaged to a Miss Lowther, sister of the first Lord Lonsdale. Wolfe's earlier love affair had affected him so deeply and for so long a period, it is doubtful if there was much romance about this one. But he had in any case scant time for improving the occasion, his hands being now full with the great enterprise on which he was bound in the early spring.

Pitt's plan for the coming season in America was to strike two great blows at Canada and a lesser one, which, if successful, would involve the conquest of that country. Wolfe, aided by a fleet, was to attack Quebec; Amherst with another force was to push through by the Lake Champlain route and unite with him if possible. A further expedition was to 
be sent against Niagara under Prideaux : but for the present we are concerned only with the first and by far the most memorable of the three.

Wolfe at this time was colonel of the 67 th regiment. $\mathrm{He}$ was to have brevet rank only of major-general while in America, since more substantial elevation would, in the eyes of Newcastle and his friends, have been almost an outrage on the British Constitution as by them interpreted. Pitt and his young officers, however, were well content to waive such trifles for the present, and concede so much of consolation to the long list of rejected incapables, in return for such honour and glory as might perchance be theirs. Wolfe's brigadiers in the forthcoming enterprise were to be Monckton, Townshend, and Murray. The first, whom we have already met in Nova Scotia, and the last were men after Wolfe's own heart. Townshend, though not a bad soldier, was inclined, on the strength of his connection, to give himself airs, was of a queer disposition, and was jealous of his young chief. Wolfe nominated his friend Carleton, of whose efficiency he was well assured, as quartermastergeneral; but the King passed his pen through the name, as Carleton was credited with certain uncomplimentary remarks concerning Hanoverians. Wolfe, however, remonstrated with much spirit, insisting that if a general was to have grave responsibility, it was only logical and fair that he should choose his own subordinates. Pitt good-naturedly went back to the King, who, after some grumbling, at last yielded the point.

The land force was to consist of 12,000 men, a few of whom were to sail from England, but the bulk were to be drawn from the American and West Indian 


\section{ARMY COLLECTS AT LOUISBOURG [1759}

garrisons. The latter, however, were counter-ordered : the former proved to be below the estimated strength, and the actual number that gathered in Louisbourg, the point of rendezvous, was only about 8,500. The command of the fleet was given to Admiral Saunders, and this appointment demanded great discretion, as the sailor in this instance had not only to be efficient on his own element, but to be a man of tact, and one who at the same time would put patriotism above professional jealousy, and could be trusted to work heartily with the land forces.

It was late in February when Saunders' fleet convoying Wolfe, his stores and a few troops sailed from Spithead. The winds being adverse and the seas running high, May had opened before the wild coast of Nova Scotia was dimly seen through whirling wreaths of fog. It was a late season, and Louisbourg harbour was still choked with ice, so the fleet had to make southwards for Halifax at the cost of much of that time which three years' experience had at length taught the British was so precious in all North American enterprises. At Halifax Wolfe found the troops from the American garrisons awaiting him. Among them was the 43rd regiment, with the gallant Major Knox, our invaluable diarist, filled with joy at the prospect of active service after twenty months' confinement in a backwoods fort, and ready with his sword as happily for us he was with his pen. In a fortnight Louisbourg was open, and both fleet and transports were grinding amidst the still drifting ice in its harbour. Here again the army was landed, and its numbers completed from the Louisbourg garrison.

There was naturally much to be done with an army brought together from so many various quarters. 


\section{9] HIGH STATE OF DISCIPLINE}

The force, too, proved, as I have said, far short of the estimate, being considerably under 9,000 men; but, on the other hand, these were all good troops and mostly veterans. Though the benefits of Bath waters had been more than neutralized by nearly three months of buffeting on the element he so loathed, Wolfe spared himself no effort. He was not only a fighting but to the highest degree an organizing general. Every sickly and unlikely man, small as was his force, was weeded out. Every commissariat detail down to the last gaiter button was carefully scrutinized. Seldom had England sent out a body of men so perfect in discipline, spirit, and material of war, and assuredly none so well commanded since the days of Marlborough. It was well it was so, seeing that they were destined to attack one of the strongest posts in the world, defended by an army nearly twice as numerous as themselves, and fighting, moreover, in defence of its home and country, and, as it fully believed, of its religion.

Wolfe's force was made up of the following regiments and corps. Under Monckton in the first brigade were the 15 th, $43 \mathrm{rd}, 58 \mathrm{th}$, and 78 th regiments, usually known then as Amherst's, Kennedy's, Anstruther's, and Fraser's (Highlanders) respectively. The second brigade, under Townshend, comprised the 28th and the 47th or Bragg's and Lascelles', with the second battalion of the 60th or Royal Americans. With Murray in the third brigade were the 35th and 48th or Otway's and Webb's, and the third battalion of the 60th. Besides these were three companies of Grenadiers from the 22nd, 40th, and 45th regiments, and a corps of light infantry, all from the Louisbourg garrison. Of colonial troops there were only five companies of rangers. 


\section{BRITISH ENTER THE ST. LAWRENCE [1759}

The young general was thoroughly alive to the numerical weakness of his force, but that he rejoiced in its efficiency is evident from his letters, and he was hard to please. "If valour can make amends for want of numbers," he wrote to Pitt, "we shall succeed."

Admiral Durell, with ten ships, had been sent forward early in May to stop French supply or warships from ascending the St. Lawrence when navigation opened. It was the 1st of June when Wolfe and Saunders with the main army followed him, owing to fog and ice and contrary winds, in somewhat straggling fashion, The bands played the timehonoured air of "The girl I left behind me," and the men cheered lustily as the ships cleared the bar, while at the mess tables, says Knox, there was only one toast among the officers-" British colours on every French fort, post, and garrison in America." With Saunders went twenty-two ships of the linefive frigates and seventeen sloops of war-besides the transports. By the 7th of June all were sailing well together along the gloomy shores of Newfoundland, whose desolate russet uplands were thickly powdered with a belated snowstorm. A week later they had left behind that hundred miles of shaggy forest which to this day envelopes the desert island of Anticosti, and were forging more cautiously along the lower reaches of the St. Lawrence. All went smoothly till the 20th, when, the wind dropping, they were caught in the cross-currents caused by the outpouring waters of the Saguenay, which, draining a vast mountain wilderness to the northward, would be accounted a mighty river if it were not for the still mightier one that absorbs it. Here 


\section{9] UNWILLING PILOTS}

the ships ran some risk of fouling, but escaped any serious damage, and in three days were at the Ile aux Coudres, where the real dangers of the navigation began. It must be remembered that such a venture was unprecedented, and regarded hitherto as an impossibility for large ships without local pilots. The very presence of the first made the second possible, for some of the vessels approaching the shore ran up French flags, whereupon numbers of the country people, in response to an invitation, came on board, little guessing the visitors could be their enemies.

Pilots were by this ruse secured, and their services impressed under pain of death. Durell, too, was waiting here, ignorant of the fact that several French provision ships had slipped past him in the fog. Three of his midshipmen, larking on the shore, had been captured and carried to Quebec, but had found much consolation and caused no little anxiety in the city by doubling the strength of the British force, when interrogated by Montcalm. Knox, who understood French, tells us that the poor unwilling pilot who took his ship up the tortuous channel made use of the most frightful imprecations, swearing that most of the fleet and the whole army would find their graves in Canada. An old British tar, on the other hand, master of a transport and possessed of an immense scorn for foreigners, would not allow a French pilot to interfere, and insisted, in the teeth of all remonstrance, on navigating his own ship. " $\mathrm{D}-\mathrm{n}$ me," he roared, "I'll convince you that an Englishman shall go where a Frenchman daren't show his nose," and he took it through in safety. "The enemy," wrote Vaudreuil soon after this to his Government, " have passed sixty ships of war where we dare not 
risk a vessel of a hundred tons by night or day." The British navy has not been sufficiently remembered in the story of Quebec.

Let us now turn for a moment to Montcalm, and see what he has been doing all this time to prepare for the attack. It was an accepted axiom in Canada that no armament strong enough to seriously threaten Quebec could navigate the St. Lawrence. In the face of expected invasion it was the Lake George and Champlain route that mostly filled the public mind. Bougainville, however, had returned from France early in May with the startling news that a large expedition destined for Quebec was already on the sea. A former opinion of this able officer's declared that three or four thousand men could hold the city against all comers. There was now four times that strength waiting for Wolfe, while his own, so far as numbers went, we know already. Eighteen transport ships, carrying supplies and some slight reinforcements, had slipped past the English eruisers in the fogs, and brought some comfort to Montcalm. The question now was how best to defend Quebec, as well as make good the two land approaches at Ticonderoga and Lake Ontario respectively.

For the defence of the city, when every ablebodied militiaman had been called out, nearly 16,000 troops of all arms would be available. About the disposition of these and the plan of defence there was much discussion. Montcalm himself was for a long time undecided. The alternative plans do not concern us here; the one finally adopted is alone to the point. Every one knows that the ancient capital of Canada is one of the most proudly placed among the cities of the earth. But it may be well to remind 
those who have not seen it, that it occupies the point of a lofty ridge, forming the apex of the angle made by the confluence of the St. Charles River and the St. Lawrence. Westward from the city this ridge falls so nearly sheer into the St. Lawrence for several miles, that, watched by a mere handful of men, it was impregnable. Moreover, the river suddenly narrows to a breadth of three-quarters of a mile opposite the town, whose batteries were regarded as being fatal to any attempt of an enemy to run past them. On the other side of the town the St. Charles River, coming in from the north-west immediately below its walls, formed a secure protection. Montcalm, however, decided to leave only a small garrison in the city itself, and go outside it for his main defence. Now, from the eastern bank of the mouth of the St. Charles, just below the city, there extends in an almost straight line along the northern shore of the St. Lawrence a continuous ridge, the brink, in fact, of a plateau, at no point far removed from the water's edge. Six miles away this abruptly terminates in the gorge of the Montmorency River, which, rushing tumultuously towards the St. Lawrence, makes that final plunge on to its shore level which is one of the most beautiful objects in a landscape teeming with natural and human interest. Along the crown of this six-mile ridge, known in history as " the Beauport lines," Montcalm decided to make his stand. So, throughout the long days of May and June the French devoted themselves to rendering impregnable from the front a position singularly strong in itself, while the Montmorency and its rugged valley protected the only flank which was exposed to attack.

At Beauport, the village which occupied the centre 


\section{ARRIVAL OF THE BRITISH}

of the ridge, Montcalm took up his headquarters with considerable confidence in the result of his preparations. In the city away upon his right he had left De Ramezy in command, who has given us a journal of the siege; but the city, though not safe from bombardment, was impregnable as things were now to assault. In his own embattled lines Montcalm had nearly fourteen thousand men as strongly intrenched as nature and art could make them. Below him spread the river, here over two miles in width from shore to shore, with the western point of the island of Orleans overlapping his left flank. Above the woods of this long, fertile island, then the garden of Canada, the French, upon the 27 th of June, first caught sight of the pennons flying from the topmasts of the English battleships, and before evening they witnessed the strange sight of red-coated infantry swarming over its well-tilled fields. It was, indeed, some days since the bonfires announcing the actual approach of the British had flared upon the mountain tops along the northern shore of the St. Lawrence, and the excitement in and around Quebec had grown to fever-heat. Wolfe himself, with Mackellar, his chief engineer, who had been both with Forbes and Braddock, was among the first to land upon the island, and, taking his stand upon its western point, scanned the noble outlook with eager gaze, and tried to realize the task that Pitt had set him.

Westward, across four miles of yet smooth and sunlit water, the great and virgin stronghold of French power clung to its rocky throne. From the river's edge to the summit of Cape Diamond rose a city that proclaimed its character at a glance, and abjured all fellowship at once with the great trading marts of 298 



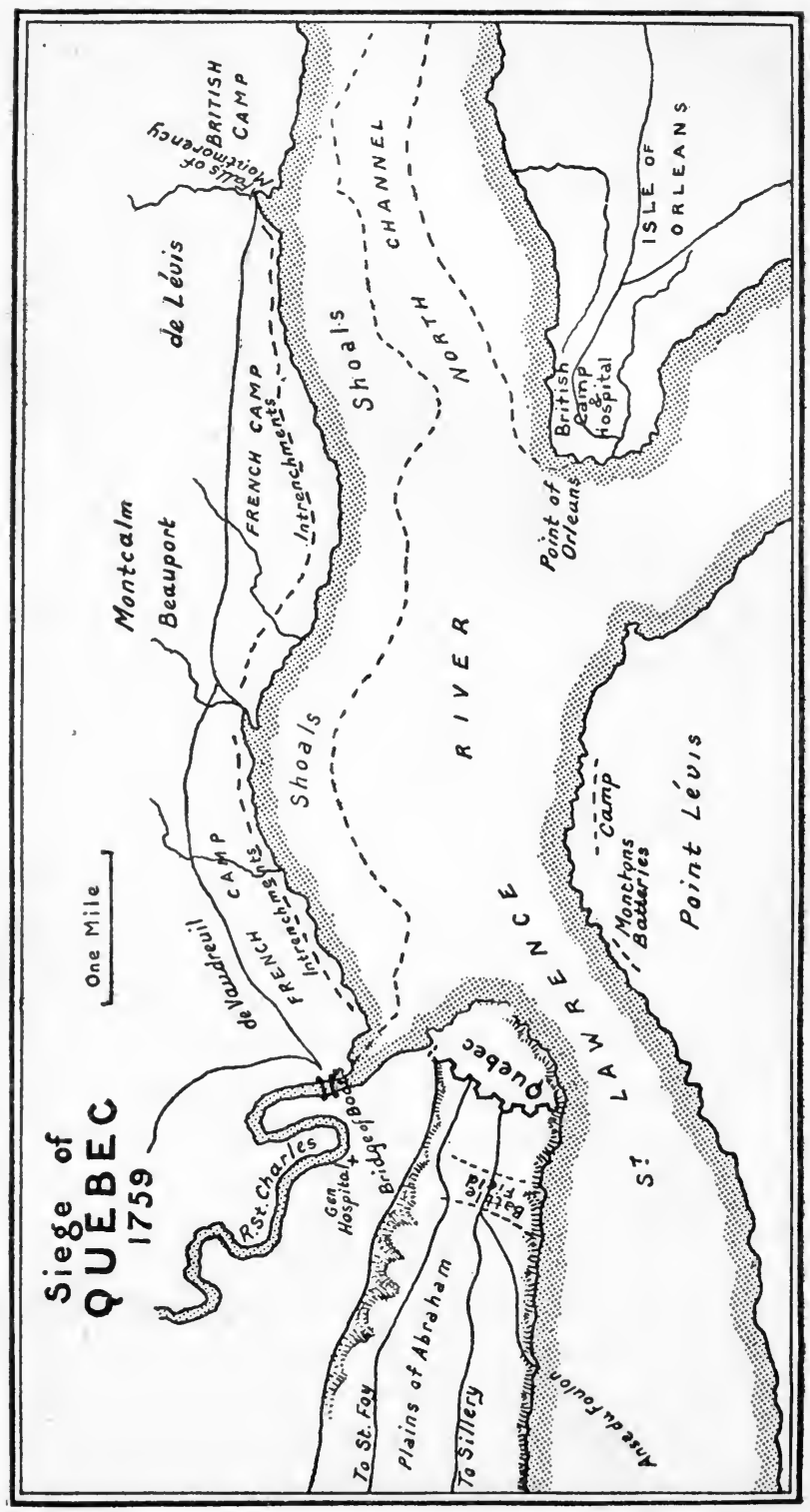




\section{9] WOLFE SURVEYS THE SITUATION}

brick and wood that greeted the visitor to the English colonies. Trade, indeed, there was:of a sort; but, mounting one above the other, tier above tier, spire and belfry, church and monastery, barrack and battery, proclaimed rather the stronghold of the soldier and the priest. As the gaze of Wolfe and his officers travelled backward to their right along the northern shore, they could see the long intrenched lines of Beauport extending past them to where the mighty cataract of Montmorency flashed against its background of green woods. The young general, however, had not much time that evening to consider the situation, which may well have appalled a less stout heart than his, for the troops had scarcely landed when a sudden summer storm burst upon the scene, churned the river into angry waves, broke some of the smaller ships from their moorings, casting them upon the rocks, and staving in many of the boats and rafts. The people of Quebec, who for weeks had been urging upon the Divinity in their peculiar way that they His chosen people were in danger, would not have been Canadian Catholics of their generation had they not been jubilant at this undoubted sign of Divine intervention. But Montcalm was the last man to presume on such favour by any lack of energy. The very next night, the British having in the meantime pitched their camp upon the isle of Orleans, they were thrown into no small alarm by the descent of a fleet of fire ships. The only men awake were the guards and sentries at the point, and as the matches were not applied to the drifting hulks till they were close at hand, the sudden effect in the darkness of the night upon the soldiers' nerves was more than they could stand, having be- 


\section{FIRE-SHIPS}

held nothing like it in their lives, and they rushed in much confusion on the sleeping camp, causing still more there. For it was not alone the flames and the explosives that were a cause of perturbation, but a hail of grape-shot and bullets from the igniting guns poured hurtling through the trees. The chief object of the fire-ships, however, was, the fleet which lay in the channel between the isle of Orleans and the shore, and towards it they came steadily drifting. Knox describes the pandemonium as awful, and the sight as inconceivably superb of these large burning ships, crammed with every imaginable explosive and soaked from their mastheads to their waterline in pitch and tar. It was no new thing, however, to the gallant sailors, who treated the matter as a joke, grappling fearlessly with the hissing, spitting demons, and towing them ashore. "Damme, Jack," they shouted, "didst ever take $\mathrm{h}-\mathrm{ll}$ in tow before?"

This exploit seems to have been a venture of Vaudreuil's, and its failure, an extremely expensive one, cost that lively egotist and his friends a severe pang. The next day Wolfe published his first manifesto to the Canadian people. "We are sent by the English king," it ran, "to conquer this province, but not to make war upon women and children, the ministers of religion, or industrious peasants. We lament the sufferings which our invasion may inflict upon you; but if you remain neutral, we proffer you safety in person and property and freedom in religion. We are masters of the river; no succour can reach you from France. General Amherst, with a large army, assails your southern frontier. Your cause is hopeless, your valour useless. Your nation have been 300 


\section{9] OCCUPATION OF POINT LÉVIS}

guilty of great cruelties to our unprotected settlers but we seek not revenge. We offer you the sweets of peace amid the horrors of war. England, in her strength, will befriend you; France, in her weakness, leaves you to your fate."

Wolfe could hardly have felt the confidence he here expressed. The longer he looked upon the French position, the less he must have liked it, and the larger must Amherst and his eventual co-operation have loomed in his mind as a necessary factor to success. But would Amherst get through to Montreal and down the St. Lawrence in time to be of use before the short season had fled? Those who were familiar with the difficulties would certainly have discouraged the hope which Wolfe for a time allowed himself to cherish; and Wolfe, though he admired his friend and chief, did not regard celerity of movement as his strongest point.

About the first move, however, in the game Wolfe had to play, there could be no possible doubt, and that was the occupation of Point Lévis. This was the high ground immediately facing Quebec, where the river, narrowing to a width of 1,200 yards, brought the city within cannon-shot from the southern bank. It was the only place, in fact, from which it could be reached. It is said Montcalm had been anxious to occupy it, and intrench it with 4,000 men, but was overruled on the supposition that the upper town, about which official Quebec felt most concern, would be outside its range of fire. If this was so, they were soon to be undeceived.

The occupation of Point Lévis by Monckton's brigade, which Wolfe now ordered on that service, need not detain us. They crossed from the camp of Orleans 


\section{A FUTILE SORTIE}

to the village of Beaumont, which was seized with slight resistance. Thence moving on along the high road to Point Lévis, they found the church and village occupied by what Knox, who was there, estimates at a thousand riflemen and Indians. The Grenadiers charging the position in front, and the Highlanders and light infantry taking it in the rear, it was stormed with a loss of thirty men, and Monckton then occupied a position which, so far as artillery fire was concerned, had Quebec at its mercy. The brigadier, who had fully expected to find French guns there, at once began to intrench himself on this conspicuous spot, while floating batteries now pushed out from Quebec and began throwing shot and shell up at his working parties, till Saunders sent a frigate forward to put an end to what threatened to be a serious annoyance.

The French had changed their minds about the danger of Monckton's guns, though not a shot had yet been fired, and agitated loudly for a sortie across the river. Montcalm thought poorly of the plan; but a miscellaneous force of 1,500 Canadians, possessed of more ardour than cohesion, insisted on attempting a night assault. They landed some way up the river, but did not so much as reach the British position. The difficulties of a combined midnight movement were altogether too great for such irregulars, and they ended by firing upon one another in the dark and stampeding for their boats, with a loss of seventy killed and wounded.

Two brigades were now in mid-stream on the Isle of Orleans, and one on Point Lévis. Landing artillery and stores, intrenching both positions, and mounting siege guns at the last-named one, consumed the 302 


\section{9] BOMBARDMENT OF QUEBEC}

first few days of July. Wolfe's skill in erecting and firing batteries had been abundantly demonstrated at Louisbourg ; and though his headquarters were on the island, he went frequently to superintend the preparations for the bombardment of Quebec. On July 12 th a rocket leapt into the sky from Wolfe's camp. It was the signal for the forty guns and mortars that had been mounted on Point Lévis to open on the city that Vaudreuil and his friends had fondly thought was out of range. The first few shots may have encouraged the delusion, as they fell short; but the gunners quickly got their distance, and then began that storm of shot and shell which rained upon the doomed city, with scarce a respite, for upwards of eight weeks. Wolfe's New England rangers, under Starke and other well-known dare-devils, trained by Rogers in the Lake George region, scoured the surrounding country, fighting Indians or stray parties of Canadians like themselves, capturing arms and stores, seizing prisoners for information, and posting up Wolfe's proclamations on the neighbouring church doors. These last assured every peasant who remained at home of good treatment; while any injuries to women or children by his own men Wolfe swore he would punish by death. He was in an enemy's country; he had double his own number of armed men before him, and a hostile population on his rear and flanks, and could do no more.

The day before the batteries of Point Lévis opened on the city Wolfe made another move. The eastern extremity of the Beauport lines pressed close upon the Montmorency gorge. If he could establish batteries upon the other bank, it would be easy not only to annoy the enemy but to investigate the course of the 


\section{THE CAMP AT MONTMORENCY [1759}

stream above the cataract, and see if perchance there might not be some way round to the back of the Beauport lines. He ordered Monckton, therefore, to make a feint up the river above the town, as if intending some mischief in that direction, while he himself brought several frigates up to the front of the Montmorency end of the Beauport lines, which kept Lévis and his militia brigade there stationed sufficiently occupied, if not seriously damaged. Under cover of these distractions he moved 3,000 men across to the mouth of the Montmorency. Landing on the eastern side, his men clambered up the wooded heights in the face of some desultory resistance. They were now upon the same ridge as Montcalm's army, whose extreme left was but a musket-shot from them. But between the combatants was the mighty gorge down which the Montmorency plunged 250 feet on to the flats below. Here Wolfe at once began to erect an intrenched camp and batteries. Parties were sent up the wooded valley of the impetuous little river to clear it of enemies, to cut timber for fascines, and to hunt for a ford. They found no ford, but encountered 400 Indians, whom they finally repulsed, though not without loss. Wolfe was somewhat higher than the French left, and could now bombard it with considerable effect. But this was of little use, as the position was apparently impregnable to attack, and there seemed no way round it; for the only ford they did eventually find was three miles up, and that faced a steep cliff and was strongly fortified. 'The French lines, too, were only vulnerable in their rear, when compared to the inaccessible front with which Nature had provided them. Upon their left they were protected by a mass of woods, while along them ran a 


\section{9] DESTRUCTION OF BUILDINGS}

continuous line of stone farmhouses and other buildings and enclosures, which, Knox tells us, were all prepared for holding garrisons. Even if Wolfe could have brought 5,000 men round the upper waters of the Montmorency and through the big woods, for the delivery of a rear attack, what a loss and what a fearful risk would have attended such an enterprise! Canadian militia-and, be it remembered, there were over 3,000 veteran regulars here as well-were not very formidable in the open, but behind cover they were as good as grenadiers, and, loose in the woods, a great deal better. Lévis, who had command of the position, which was now engaged in an artillery duel and some outpost skirmishing with the British, was anxious to attack. Montcalm, whose only fear was Amherst, would not hear of it. "If we move them," he said, "they will be more mischievous elsewhere. Let them stay there and amuse themselves."

The rain of shot and shell continued to pour upon Quebec. Houses, churches, and monasteries, crashed and crumbled beneath the pitiless discharge. The great cathedral, where the memories and the trophies of a century's defiance of the accursed heretic had so thickly gathered, was gradually reduced to a skeleton of charred walls. The church of Notre Dame de la Victoire, erected in gratitude for the delivery of the city from the last and only previous attack upon it sixty years before, was one of the first buildings to suffer from the far more serious punishment of this one. Wolfe, though already suffering from more than his chronic ill-health, was ubiquitous and indefatigable; now behind Monckton's guns at Point Lévis, now with Townshend's batteries at Montmorency, now up the river, ranging with his glass those miles of 


\section{SHIPS PASS THE BATTERIES [1759}

forbidding cliffs which he may already have begun to think he should one day have to climb. Some of Saunders' ships were in the Basin, between Orleans and Quebec, and frequently engaged with Montcalm's floating batteries; while in the meantime, the roar of artillery from a dozen different quarters filled the simmering July days, and lit the short summer nights with fiery shapes, and drew in fitful floods the roving thunder clouds that at this season of the year in North America are apt to lurk behind the serenest sky.

Fighting at close quarters there was, too, in plenty, though of an outpost and backwoods kind, Bois Herbert, with his painted Canadians and Abernakis Indians, and Stark and young Rogers with their colonial rangers-Greek against Greek-scalped each other with an hereditary ferocity that English and French regulars knew nothing of. In bringing a fleet up to Quebec, British sailors had already performed one feat pronounced impossible by Canadian tradition. They now still further upset their enemies' calculations by running the gauntlet of the batteries of Quebec and placing the Sutherland, with several smaller ships, at some distance up the river. This cost Montcalm 600 men, whom he had to send under Dumas to watch the squadron. But all this brought the end no nearer. Time was exceeding precious, and July was almost out. Necessary messages were continually passing under flags of truce, and superfluous notes of defiance sometimes accompanied them. "You may destroy the town," said De Ramezay to Wolfe, "but you will never get inside it." "I will take Quebec," replied the fiery stripling, "if I stay here till November." 


\section{9] MONTCALM IMMOVEABLE}

Wolfe, however, was chafing sorely under a sense of impotence. ${ }^{1}$ Montcalm would not stir. Why should he? And there seemed no single point at which he was even reasonably vulnerable to a far inferior force. Only one man in the army knew the enemy's ground, and that was Stobo, who was Washington's brother officer in the very first blow struck in this war, at Fort Necessity in 1754. He had been left at Fort Duquesne, it may be remembered, as a hostage on that occasion, whence he was forwarded to Quebec. A plan of Duquesne, drawn by him, however, had been found in Braddock's baggage, and he was sentenced to death, but managed to escape, and was now at Wolfe's side with a local knowledge that must have been acceptable.

Wolfe had now decided that some forward action was necessary, and he proceeded to select what seemed to him the only spot that offered the barest justification for the risk.

This was close to the Montmorency end of the Beauport lines, and July 31st was the date fixed for the enterprise, into which he purposed to bring four thousand men. Now in the short space between the foot of the falls and the St. Lawrence, the Montmorency was fordable at low tide, and Townshend, with 2,000 men from the British camp was to ford it here, and advance along the shore. Wolfe, with an equal number from Monckton's brigade at Point Lévis and the Isle of Orleans, was, at the same time, to approach in flat-bottomed boats over the shallows and land upon the narrow flats beneath the high embattled

1 He was short of money too; and, in a former despatch to his Government, had somewhat quaintly remarked "this is, perhaps, the first siege that has been undertaken without it." 


\section{ATTACK ON THE BEAUPORT LINES}

ridge which overlooked them. A frigate was brought up to make play on the French lines, and all the batteries of the Montmorency camp were to help sustain the attack, while a "cat," a kind of sailing raft, armed with several guns, was to be imbedded on the muddy shore.

At about ten in the morning the movement began from Point Lévis to the Isle of Orleans, and de Lévis and Montcalm from their high perch on the French redoubts had a clear view of everything that passed. They were puzzled what to make of it, and thinking a rear attack by the upper reaches of the Montmorency might be intended, sent 500 men to watch the ford. As the day went on, it became evident to Lévis that his own intrenchments were at one point or another the object of attack; but concentration for the French at any point on the Beauport lines was an easy matter. Wolfe had to await the ebbing tide for Townshend's corps to ford the mouth of the Montmorency, during which his own men were concentrated on the Point of Orleans. In the afternoon the Centurion frigate, the armed "cat," and the batteries across the falls opened on the French ridges. As the day waned Wolfe and his small force pushed out and rowed towards the flats, while Townshend awaited at the ford the signal to advance. The general, always in the front, soon came within the range of the French batteries, which opened with a brisk fire. He was three times struck by splinters, and his cane was knocked from his hand by a round shot. Worse still, the water at this point proved too shallow, and some of the boats ran upon ledges of rock or mud. A deeper passage, however, was quickly found, and the leading files, Grenadiers and Royal 308 


\section{MADNESS OF THE GRENADIERS}

Americans, were, in due course, landed on the wet sand. A musket-shot in front, where dry ground and tide limit touched, was an outlying redoubt, which was at once rushed and cleared without difficulty. Now, however, comes the moment when Wolfe's plan of action would have developed. This has never yet been quite clear, in spite of his own despatches, but what immediately happened was of all things the least expected.

Beyond the captured redoubt were about 200 yards of flat ground, behind which abruptly rose the high ridge, where the French army lay intrenched. Wolfe may have intended a mere reconnaissance in force over the Flat, though he told Pitt he hoped to tempt the French down on to it. Townshend was nearing him, having just crossed the ford, while Monckton was in the very act of landing with a thousand men. Somewhat less than that number stood round Wolfe at the captured redoubt. But even with this respectable force, it seems incredible that he would have faced that steep hill, which by this time was lined by a great part of the French army. What was passing in that nimble mind just then, or what Wolfe would have done,- and he was not a man, with all his ardour, to throw his men's lives away,-no one will ever know. The Grenadiers and Royal Americans, under a thousand men in all, saved him the trouble of deciding. Seized with a sudden and unaccountable insanity, these veteran soldiers, without orders and without formation, without waiting for their companions, and in utter disregard of the invectives of their officers, who had nothing for it but to go with them, rushed with a wild shout upon the fatal slope. Slippery with recent rains, its summits bristling with 309 
cannon and packed with 3,000 riflemen, half of whom were regulars, with other 10,000 men at ready call; never, surely, was there so pitiable a piece of madness. But it was long, too long, ere the hail of lead that swept down that steep and slippery slope up which these insubordinate heroes vainly and wildly struggled, could stop them. Black clouds had been gathering over head. A thunderstorm was mutely raging beneath the roar of over a hundred cannon and the din of countless rifles, and now at the most dramatic moment down fell the rain in sheets so fast and thick as to hide the combatants from each other, and effectually quench both their ardour and their fire. To support such an escapade would have been madness, and the survivors soon enough came straggling back through the storm, which quickly cleared and showed a streaming hillside covered with British dead and wounded. The 78th Highlanders were instantly sent forward to bring off the latter, already in imminent danger from Indian scalping-knives. Either from damp powder or a worthier cause the effort was allowed to pass with impunity, and the British retired despondently, some by land and some by water, bearing the wounded with them to their several camps. The mad and brief exploit, for which no officer high or low was responsible, cost Wolfe 443 men, including 33 officers. There we will leave it as one of the most unaccountable incidents in our military history, for the Grenadiers were picked men from three regiments at Louisbourg. Wolfe, with his usual consideration, went out of his way to show their officers that he wholly exonerated them from blame. In his orders the next morning, however, he soundly rated the men themselves for their " im- 
petuous, irregular, and unsoldierlike proceeding," reminding them of the difficulty in which they had placed their comrades, and ironically asking if they supposed that they alone could beat the whole French army. He also wrote a despatch to Pitt, which remains as notable for the abilities it displays as for the disappointment it caused at the time.

Through the whole weary month of August little occurred that the exigencies of our space would justify recording. Montcalm, after the late affair, considered himself safe, and he even allowed two thousand Canadians to leave for the harvest. Wolfe had a thousand men of his small force sick or wounded in hospital. Amherst, it was reported, had taken Ticonderoga, but there was little likelihood of his getting through to their assistance. Prideaux, in the far West, as it then was, had captured Niagara. It was a great success, but it in no way helped Wolfe. In an army distinguished for its spirit the conviction was growing that the task set it was impossible. Montcalm would not stir out of his defences. "The old fox," writes Wolfe to his mother, "has a large army of bad troops, while I have a small army of good ones." But three parts of Montcalm's large army, like that of the Boers, were habitual riflemen, formidable behind cover, though comparatively useless in the open. People in England, too, who knew about as much of Quebec as of the mountains in the moon, had begun to grumble and to misdoubt this young general of Pitt's. Though the coffee-houses could not show him the right road to glory, as their equivalents are apt to show his successors at the present day, for they had not the printed materials necessary for such a campaign. Worry, anxiety, and 


\section{WOLFE ILL}

hard work, too, had long been telling on Wolfe's feeble frame. " Don't talk to me of constitution," he had said, referring to a brother officer's case ; "spirit will carry a man through anything." But human endurance has its limits, and on the 20th of August it was known through the army that the general, who had made himself the object of its entire devotion, could not rise from his bed. For nearly a week Wolfe lay prostrated with fever, and tortured with a despair that under the circumstances was inevitable to his physical prostration. The four walls of his sick-chamber in the farmhouse at Montmorency may well have typified to his fevered fancy the inaccessible barriers which upon every side in the larger arena without doors checked his advance to victory. He regarded himself, we know, as a ruined man, and had dread visions of his return to England, another unsuccessful general to be pelted by a public opinion which in truth, as regards military matters, he held in infinite scorn. On the 25th, however, "to the inconceivable joy," says honest Knox, "of the whole army," its beloved commander was reported out of danger, and he at once set his busy mind to work and called his brigadiers in council to see if anything could be done to utilize the short season that remained. When, on the 1st of September, Wolfe rose from his sick-bed, he had made up his mind to attempt the enterprise which cost him his frail life and gave immortality to himself, and a great colony to England.

It must not be supposed, however, that August had passed away in humdrum fashion. The guns had roared with tireless throats, and the lower town was a heap of ruins. Far away down both banks of 
the St. Lawrence, the dogs of war had raged through seigneuries and hamlets. Between the upper and the nether millstone of Wolfe's proclamations and Montcalm's vengeance, the wretched peasantry were in a sore plight. Raided through and through by the fierce guerillas of North American warfare, swept bare of grain and cattle for Wolfe's army, the fugitives from smoking farms and hamlets were glad to seek refuge in the English lines, where the soldiers generously shared with them their meagre rations. More than one expedition had been sent up the river. Admiral Holmes, with over twenty ships, was already above the town, and had driven the French vessels, which had originally taken refuge there, to discharge their crews and run up shallow tributaries. Murray, with twelve hundred men, had been carried up as far as Deschambault, and had there done some successful but unprofitable fighting. The shore was strongly fortified at every accessible point. Montcalm depended wholly on that side for his supplies, for the lower country was entirely closed to him by the British. He lost Lévis, too, at this time, and 1,500 men, who, owing to Prideaux's victory and Amherst's steady advance, were required at Montreal. Another 1,500 men he had despatched under Bougainville to Cap Rouge, where the seven miles of cliff which made the north shore west of Quebec impregnable, ceased; and here that able officer intrenched himself at the mouth of a small stream.

Wolfe's intention now was to place every man that he could spare on board the ships in the upper river, and his entire force was reduced by death, wounds, and sickness to under 7,000 men. On September 3rd, with slight annoyance from an ill-directed cannon 


\section{WOLFE AGAIN ILL}

fire, he removed the whole force at Montmorency across the water to the camps of Orleans or Point Lévis. On the following day all the troops at both these stations which were not necessary for their protection were paraded; for what purpose no one knew, least of all the French, who from their lofty lines could mark every movement in the wide panorama below, and were sorely puzzled and perturbed. Some great endeavour was in the wind, beyond a doubt; but both Wolfe and his faithful ally, the admiral, did their utmost to disguise its import. And for this very reason it would be futile, even if necessary, to follow the fluctuating manœuvres that for the next few days kept the enemy in constant agitation: the sudden rage of batteries here, the threatening demonstrations of troop-laden boats there, the constant and bewildering movement of armed ships at every point. It was well designed and industriously maintained, for the sole purpose of harassing the French and covering Wolfe's real intention. On the night of September 4th the general was well enough to dine with Monckton's officers at Point Lévis, but the next day he was again prostrate with illness, to the great anxiety of his army. He implored the doctor to "patch him up sufficiently for the work in hand; after that nothing mattered." Chronic gravel and rheumatism, with a sharp low fever, aggravated by a mental strain of the severest kind, all preying on a sickly frame, were what the indomitable spirit therein imprisoned had to wrestle with. On the 6th, however, Wolfe struggled up, and during that day and the next superintended the march of his picked column, numbering some 4,000 men, up the south bank of the 


\section{9] TROOPS ASCEND THE RIVER}

river. Fording, near waist-deep, the Etchemain river, they were received beyond its mouth by the boats of the fleet, and as each detachment arrived conveyed on board. The 48th, however, 700 strong, were left, under Colonel Burton, near Point Lévis to await orders.

The fleet, with Wolfe and some 3,600 men on board, now moved up to Cap Rouge, behind which, at the first dip in the high barrier of cliffs, was Bougainville with 1,500 men (soon afterwards increased), exclusive of 300 serviceable light cavalry. The cove here was intrenched, and the French commander was so harried with feigned attacks that he and his people had no rest. At the same time, so well was the universal activity maintained that Montcalm, eight miles below, was led to expect a general attack at the mouth of the Charles river, under the city. Throughout the 8th and 9 th the weather was dark and rainy and the wind from the east, an unfavourable combination for a movement requiring the utmost precision. On the 10th the troops from the crowded ships were landed to dry their clothes and accoutrements. Wolfe and his brigadiers now finally surveyed that line of cliffs which Montcalm had declared a hundred men could hold against the whole British army. It was defended here and there by small posts. Below one of these, a mile and a half above the city, the traces of a zigzag path up the bush-covered precipice could be made out, though Wolfe could not see that even this was barricaded. Here, at the now famous Anse du Foulon, he decided to make his attempt.

The ships, however, kept drifting up and down between Cap Rouge and the city, with a view to maintaining the suspense of the French. Each morning 


\section{WOLFE'S LAST ORDERS}

Wolfe's general orders to the soldiers were to hold themselves in readiness for immediate action, with as full directions for their conduct as was compatible with the suppression of the spot at which they were to fight. On the night of the 11th the troops were reimbarked, and instructions sent to Burton to post the 48th on the south shore opposite the Anse du Foulon. On the following day, Wolfe published his last orders, and they contained a notable sentence : "A vigorous blow struck by the army at this juncture may determine the fate of Canada." Almost at the same moment his gallant opponent from his headquarters at Beauport was writing to Bourlamaque at Montreal that he gave the enemy a month or less to stay, but that he himself had no rest night or day, and had not had his boots or elothes off for a fortnight. Another Frenchman was informing his friends that what they knew of that "impetuous, bold, and intrepid warrior, Monsieur Wolfe," gave them reason to suppose he would not leave them without another attack.

A suspicious calm brooded over the British squadron off Cap Rouge as Bougainville watched it from the shore throughout the whole of the 12th. The men were under orders to drop into their boats at nine, and were doubtless busy looking to their arms and accoutrements. Wolfe had sent for his old schoolfellow, "Jacky" Jervis, afterwards the famous admiral, who was commanding a sloop in the river. It was a matter of private business, and as the two sat together in the cabin of the Sutherland the general took a miniature of Miss Lowther, ${ }^{1}$ his fianceee, from

${ }^{1}$ It is a curious coincidence that the heroines of both Wolfe's love affairs should have come, and that through no connection with 
around his neck, and remarking that he did not expect to survive the battle he hoped to fight upon the following day, requested Jervis in such case to deliver the portrait to the lady, who, it may be added became, six years later, the last Duchess of Bolton, and lived to be seventy-five.

By a preconcerted arrangement the day was spent after a very different fashion in the basin of Quebec. Constant artillery fire and the continual movement of troops against various parts of the Beauport lines engaged the whole attention of Montcalm, who had, in fact, little notion what a number of men had gone up the river with Wolfe. When night fell upon the ruined city and the flickering camp fires of the long French lines, the tumult grew louder and the anxiety greater. The batteries of Point Lévis and the guns of Saunders' ships redoubled their efforts. Amid the roar of the fierce artillery, served with an activity not surpassed during the whole siege, Montcalm, booted and spurred, with his black charger saddled at the door, awaited some night attack. The horse would be wanted yet, but for a longer ride than his master anticipated, and, as it so turned out, for his last one. Up the river at Cap Rouge all was silence, a strange contrast to the din below. The night was fine, but each other, but quite fatuitously, from the same group of families as it were, in a remote corner of England, which Wolfe in a social sense never even visited. Isell Hall, whence came Miss Lawson, is still a residence of the family. A beautiful specimen of the border Peel tower enlarged during the Tudor period into a mansion; romantically situated on the banks of the Derwent between Cockermouth and Bassenthwaite. Meaburn Hall, Kate Lowther's early home, though now a somewhat inaccessible farmhouse, between Shap and Appleby, on the Lowther estates, remains a most interesting and picturesque specimen, both inside and out, of the Tudor manor house of the border country. 


\section{THE MIDNIGHT VOYAGE}

dark, and was some three hours old when a single light gleamed of a sudden from the Sutherland's mainmast. It was the signal for 1,600 men to drop quietly into their boats. A long interval of silence and suspense then followed, till at two o'clock the tide began to ebb, when a second lantern glimmered from Wolfe's ship. The boats now pushed off and drifted quietly down in long procession under the deep shadow of the high northern shore.

The ships followed at some distance with the remainder of the force under Townshend, the 48th, it will be remembered, awaiting them below. The distance to be traversed was six miles, and there were two posts on the cliffs to be passed. French provision boats had been in the habit of stealing down in the night, and to this fact, coupled with the darkness, it seems Wolfe trusted much. He was himself in one of the leading boats, and the story of his reciting "Gray's Elegy," in solemn tones while he drifted down, as he hoped, to victory and, as he believed, to death, rests on good authority. ${ }^{1}$ The tide was running fast, so that the rowers could ply their oars with a minimum of disturbance. From both posts upon the cliff their presence was noticed, and the challenge of a sentry rang out clear upon the silent night. On each occasion a Highland officer who spoke French perfectly replied that they were a provision convoy, to the satisfaction of the challengers. But the risk was undeniable, and illustrates the hazardous nature of the enterprise. Wolfe's friend, Captain Howe, brother of the popular young nobleman who fell at Ticonderoga, with a small body of picked

1 Professor Robson of Edinburgh University, who was present as a midshipman. 
soldiers, was to lead the ascent, and as the boats touched the narrow beach of the Anse du Foulon he and his volunteers leaped rapidly on shore. Some of the boats accidentally overran the spot, but it made little difference, as the narrow path was, in any case, found to be blocked, and the eager soldiers were forced to throw themselves upon the rough face of the cliff, which was here over 200 feet high, but fortunately sprinkled thick with stunted bushes. Swiftly and silently Howe and his men scrambled up its steep face. No less eagerly the men behind, as boat after boat discharged its load of redcoats under Wolfe's eye on the narrow shore, followed in their precarious steps. Day was just beginning to glimmer as the leading files leaped out on to the summit and rushed upon the handful of astonished Frenchmen before them, who fired a futile volley and fled. They captured, however, the officer of the guard. It was De Vergor, who, it will be remembered, made such a poor defence at Beausejour, in Nova Scotia, whither Bigot had sent him to improve his fortunes. He was really in bad luck this time, though he has been made a scapegoat of by French writers. An attack at such a point may well have seemed improbable. "The difficulty of the ascent," wrote Admiral Saunders to the Ministry, "was scarcely credible." The single narrow path, too, the only presumable approach, had been blocked ; but Wolfe's men were dragging themselves up all along the cliff, and even if De Vergor's small guard had been more wide awake, it is doubtful if they could have stopped such determined men. But the shots and cries had alarmed other posts at some distance off, yet near enough to fire in the direction of the landing boats. 


\section{ON THE PLAINS OF ABRAHAM [1759}

It was too late, however; the path had now been cleared of obstacles, and the British were swarming on to the plateau. The first sixteen hundred men had been rapidly disembarked, and the boats were already dashing back for Townshend's brigade, who were approaching in the ships, and for the 48th, who awaited them on the opposite shore.

The scattered French posts along the summit were easily dispersed. while the main army at Beauport, some miles away, on the far side of the city, were as yet unconscious of danger. Bougainville and his force back at Cap Rouge were as far off and as yet no wiser. Quebec had just caught the alarm, but its weak and heterogeneous garrison had no power for combined mobility. By six o'clock Wolfe had his whole force of 4,300 men drawn up on the plateau, with their backs to the river and their faces to the north. Leaving the Royal Americans, 540 strong, to guard the landing-place, and with a force thus reduced to under 4,000 , he now marched towards the city, bringing his left round at the same time in such fashion as to face the western walls scarcely a mile distant. As Wolfe drew up his line of battle on that historic ridge of tableland known as the Plains of Abraham, his right rested on the cliff above the river, while his left approached the then brushy slope which led down towards the St. Charles Valley. He had outmanœuvred Montcalm; it now remained only to crush him. Of this Wolfe had not much doubt, though such confidence may seem sufficiently audacious for the leader of $4,000 \mathrm{men}$, with twice that number in front of him and half as many in his rear, both forces commanded by brave and skilful generals. But Wolfe counted on quality, 
not on numbers, which Montcalm himself realized were of doubtful efficacy at this crucial moment.

The French general, in the meantime, had been expecting an attack all night at Beauport, and his troops had been lying on their arms. It was about six o'clock when the astounding news was brought him that the British were on the plateau behind the city. The Scotch Jacobite, the Chevalier Johnstone, who has left us an account of the affair, was with him at the time, and they leaped on their horses-he to give the alarm towards Montmorency, the general to hasten westwards by Vaudreuil's quarters to the city. "This is a serious business," said Montcalm to Johnstone as he dug his spurs into his horse's flanks. Vaudreuil, who in his braggart, amateur fashion had been "crushing the English" with pen and ink and verbal eloquence this last six weeks, now collapsed, and Montcalm, who knew what a fight in the open with Wolfe meant, hastened himself to hurry forward every man that could be spared. Fifteen hundred militia were left to guard the Beauport lines, while the bulk of the army poured in a steady stream along the road to Quebec, over the bridge of the St. Charles, some up the slopes beyond, others through the tortuous streets of the city, on to the Plains of Abraham. Montcalm, by some at the time, and by many since, has been blamed for precipitating the conflict, but surely not with justice! He had every reason to count on Bougainville and his 2,300 men, who were no further from Wolfe's rear than he himself was from the English front. The British held the entire water. Wolfe once entrenched on the plateau, the rest of his army, guns and stores could be brought up at will, and the city defences on that 


\section{BOUGAINVILLE}

side were almost worthless. Lastly, provisions with the French were woefully scarce; the lower country had been swept absolutely bare. Montcalm depended on Montreal for every mouthful of food, and Wolfe was now between him and his source of supply.

By nine o'clock Montcalm had all his men in front of the western walls of the city and was face to face with Wolfe, only half a mile separating them. His old veterans of William Henry, Oswego, and Ticonderoga were with him, the reduced regiments of Béarn, Royal Rousillon, Languedoc, La Sarre and La Guienne, some 1,300 strong, with 700 colony regulars and a cloud of militia and Indians. Numbers of these latter had been pushed forward as skirmishers into the thickets, woods, and cornfields which fringed the battlefield, and had caused great annoyance and some loss to the British, who were lying down in their ranks, reserving their strength and their ammunition for a supreme effort. Three pieces of cannon, too, had been brought to play on them-no small trial to their steadiness; for, confident of victory, it was not to Wolfe's interest to join issue till Montcalm had enough of his men upon the ridge to give finality to such a blow. At the same time the expected approach of Bougainville in the rear had to be watched for and anticipated. It was indeed a critical and anxious moment. The 48th regiment were stationed as a reserve of Wolfe's line, though to act as a check rather to danger from Bougainville than as a support to the front attacks in which they took no part. Part, too, of Townshend's brigade, who occupied the left of the line nearest to the wooded slopes in which the plain terminated, were drawn up en potence, or at right 


\section{9] WOLFE'S LINE OF BATTLE}

angles to the main column, in case of attacks from flank or rear. The Bougainville incident is, in fact, a feature of this critical struggle that has been too generally ignored, but in such a fashion that inferences might be drawn, and have been drawn, detrimental to that able officer's sagacity. Theoretically he should have burst on the rear of Wolfe's small army, as it attacked Montcalm, with more than 2,300 tolerable troops. He was but six miles off, and it was now almost as many hours since the British scaled the cliff. Pickets and a small battery or two between himself and Wolfe had been early in the morning actually engaged. The simple answer is that Bougainville remained ignorant of what was happening. Nothing but an actual messenger coming through with the news would have enlightened him, and in the confusion none came till eight o'clock. The sound of desultory firing borne faintly against the wind from the neighbourhood of the city had little significance for him. It was a chronic condition of affairs, and Bougainville's business was to watch the upper river, where an attack was really expected. It was a rare piece of good fortune for Wolfe that the confusion among the French was so great as to cause this strange omission. But then it was Wolfe's daring that had thus robbed a brave enemy of their presence of mind and created so pardonable a confusion.

The constituents of that ever-memorable line of battle which Wolfe drew up on the Plains of Abraham must of a surety not be grudged space in this chapter. On the right towards the cliffs of the St. Lawrence were the $28 \mathrm{th}$, the $35 \mathrm{th}$, the $43 \mathrm{rd}$, and the Louisbourg Grenadiers under Monckton. In the centre, under Murray, were the 47th, 58th, and the 


\section{THE ATTACK}

78th Highlanders. With Townshend on the left were the 15th (en potence) and the 2 nd battalion of the 60th or Royal Americans-in all somewhat over 3,000 men. In reserve, as already stated, was Burton with the 48th, while Howe with some light infantry occupied the woods still farther back, and the 3rd battalion of the 60th guarded the landingplace. None of these last corps joined in the actual attack.

When Montcalm, towards ten o'clock, under a cloudy but fast-clearing sky, gave the order to advance, he had, at the lowest estimate from French sources, about 3,500 men, exclusive of Indians and flanking skirmishers, who may be rated at a further 1,500. The armies were but half a mile apart, and the French regulars and militia, being carefully but perhaps injudiciously blended along their whole line, went forward with loud shouts to the attack.

The British, formed in a triple line, now sprang to their feet and moved steadily forward to receive the onset of the French. Wolfe had been hit on the wrist, but hastily binding up the shattered limb with his handkerchief, he now placed himself at the head of the Louisbourg Grenadiers, whose temerity against the heights of Beauport, in July, he had so soundly rated. He had issued strict orders that his troops were to load with two bullets, and to reserve their fire till the enemy were at close quarters. He was nobly obeyed, though the French columns came on firing wildly and rapidly at long range, the militia throwing themselves down, after their backwoods custom, to reload, to the disadvantage of the regular regiments among whom they were mixed. The British fire, in spite of considerable punishment, was admir- 
ably restrained, and when delivered it was terrible. Knox tells us the French received it at forty paces, that the volleys sounded like single cannon shots, so great was the precision, and French officers subsequently declared they had never known anything like it. Whole gaps were rent in the French ranks, and in the confusion which followed, the British reloaded with deliberation, poured in yet another deadly volley, and with a wild cheer rushed upon the foe. They were the pick of a picked army, and the shattered French, inured to arms in various ways though was every man of them, had not a chance. Montcalm's 2,000 regulars were ill supported by the still larger number of their comrades, who, unsurpassed behind breastworks or in forest warfare, were of little use before such an onslaught. The rush of steel, of bayonet on the right and centre, of broadsword on the left, swept everything before it and soon broke the French into a flying mob, checked here and there by brave bands of white-coated regulars, who offered a brief but futile resistance. Wolfe, in the meantime, was eagerly pressing forward at the head of his Grenadiers, while behind him were the 28th and the 35th, of Lake George renown. One may not pause here to speculate on the triumph that must at such a moment have fired the bright eyes that redeemed his homely face and galvanised the sickly frame into a very Paladin of old as sword in hand he led his charging troops. Such inevitable reflections belong rather to his own story than to that of the long war which he so signally influenced, and it was now, in the very moment of victory, as all the world well knows, that he fell. He was twice hit in rapid succession-a ball in the groin which did not stop 


\section{DEATH OF WOLFE}

him, and a second through the lungs, against which his high courage fought in vain. He was seen to stagger by Lieutenant Browne of the Grenadiers and 2nd regiment, who rushed forward to his assistance. "Support me," exclaimed Wolfe, "lest my gallant fellows should see me fall." But the lieutenant was just too late, and the wounded hero sank to the ground; not, however, before he was also seen by Mr. Henderson, a volunteer, and almost immediately afterwards by an officer of artillery, Col. Williamson, and a private soldier whose name has not been preserved. The accurate Knox himself was not far off, and this is the account given him by Browne that same evening, and seems worthy to hold the field against the innumerable claims that have been set up in the erratic interests of "family tradition":-

These four men carried the dying general to the rear, and by his own request, being in great pain, laid him upon the ground. He refused to see a surgeon, declared it was all over with him, and sank into a state of torpor. "They run! see how they run!" cried out one of the officers. "Who run?" asked Wolfe, suddenly rousing himself. "The enemy, sir ; egad, they give way everywhere." "Go one of you, my lads," said the dying general, "with all speed to Colonel Burton, and tell him to march down to the St. Charles River and cut off the retreat of the fugitives to the bridge." He then turned on his side, and exclaiming, "God be praised, I now die in peace," sank into insensibility, and in a short time, on the ground of his victory which for all time was to influence the destinies of mankind, gave up his life contentedly at the very moment, to quote Pitt's stirring eulogy, "when his fame began." 


\section{CHAPTER XI}

WITH the fall of Wolfe, the chief command devolved on Monckton; but that gallant officer, like his chief, was stretched upon the ground with a ball through his lungs, though the wound in this case was happily not a fatal one. It then fell upon Townshend to clinch the victory won by the man whom he alone of all the army had been inclined to belittle, and no fault can be found with the fashion in which he did it.

The main part of the battle was over in twenty minutes. Montcalm's army was swept in such headlong rout and confusion from the field that isolated efforts to stem the tide were futile, and the brave French general, who, mounted on his black horse, had done his utmost to rally the broken troops, was now in this bitter hour himself struck down with a mortal wound. But on either flank of the actual battlefield there had been resistance of a most effective kind. Large bodies of Canadian irregulars and Indians had thrown themselves into the bordering woods, and poured a hot fire into the victorious British. There were no Rangers on the spot, and it had fallen to the lot of the Highlanders and light infantry to clear the woods as they advanced. The former, rashly trusting to their broadswords only, lost 160 out of 600 men, mostly in this perilous performance. 


\section{FRENCH AND BRITISH LOSSES [1759}

After a time, however, these flanking sharpshooters of the enemy were driven from their cover to swell the panic-stricken mob of fugitives who were choking the gates of Quebec and the approaches to the bridge over the St. Charles. The guns of the city, however, had no immediate reason to share in the general paralysis, and Townshend sounded the recall as they began to play upon his pursuing troops. Trenching tools and guns were being rapidly brought up from the Anse du Foulon, and no time was lost in strengthening the position. An advanced party of Bougainville's force had actually attacked the rear during the battle, but the troops left in reserve had repulsed them without difficulty. The main column now arrived, but it was too late, for Montcalm's army had vanished, and 4,000 veterans flushed with victory barred the way.

The loss of the French during the action was about 1,500, including 250 prisoners. Of the British, 58 were killed and 597 wounded. Knox tells us that many of the French officers who were taken were still haunted with fears of vengeance for Fort William Henry, and with bared heads protested earnestly that they had taken no part in that lamentable massacre. Montcalm, shot through the abdomen, lay dying within the ruined town. When told that he had only twelve hours to live, he professed satisfaction, since he would not in that case be a witness of the surrender of the city. $\mathrm{He}$ declared that as he was fated to be beaten, he was glad it was by so brave an enemy. He refused to issue any more orders, saying his time was too short, and he would fain be left alone. He did not, however, forget his soldiers, and dictated a generous note 


\section{9] DEATH OF MONTCALM}

to Townshend, on behalf of his prisoners and the Canadians generally, assuring him at the same time of his confidence in the humanity of the English.

"Be their protector," he winds up with touching quaintness, "as I have been their father."

The brave gentleman and able soldier died before the dawn. In the confusion no coffin was forthcoming. His remains were placed in a deal box, and, escorted by a few officers of the garrison and a troop of women and children, were borne to the chapel of the Ursulines, and deposited in a grave made by the bursting of a British shell.

Vaudreuil, in the meantime, met the fugitives from the battlefield at the bridge over the St. Charles, where there was a scene of indescribable confusion. Every one had lost their heads, and veteran officers were clamouring for a surrender, crying out that the British were upon them, and that they would be cut to pieces.

The British, as a matter of fact, had ceased from the pursuit, and were concentrating on their lines, worn out with exhaustion and fatigue. Nothing, however, could allay the panic of the French, which indeed passed all reason. A council of war was called. Vaudreuil loudly blamed Montcalm for precipitating a conflict which he himself carefully shirked, and then proceeded to give a taste of his courage and generalship by urging a retreat up the river of the whole army. In the demoralized state of the French his suggestions met with an only too ready response. The whole position of Beauport was abandoned, just as it stood, tents and all, to be looted by country people and the Indians. Bougainville was notified of the movement, and at dark 


\section{FLIGHT OF THE FRENCH ARMY [1759}

that same evening the entire French force, except the militiamen who deserted to their homes and the feeble garrison within the city, were hurrying round the British position at a pace which the Chevalier Johnstone, who was with them, calls a disgraceful rout. Not only Montcalm, but Senezergue and De L'Ours, his second and third in command, had been mortally wounded. De Ramezay, with a thousand quite inefficient men, mere citizens for the most part, was left in the city with instructions to surrender if an assault should be threatened. The remnant were not lacking in spirit, and had endured the siege without murmur, but to expect more of them at this moment was ridiculous. If the French army, they justly urged, was afraid to again face Wolfe's victorious battalions, what could be expected of a few hundred half-starved old men and boys, with only a score or two sailors and soldiers to stiffen them?

The French army, in the meantime, did not stay their rapid flight till they had placed thirty miles behind them and reached Jacques Cartier on the St. Lawrence. A message had been sent on the day of battle to Lévis at Montreal, who was now in chief command, and Vaudreuil's expectations that he would descend the river and meet them at Jacques Cartier were well founded. When that brave and vigorous soldier reached the camp of the fugitive army he was filled with indignation, as well he may have been. To a man who had more than once won victories against great odds the situation was humiliating enough. Never in their darkest days of inexperience, indiscipline, and bad leadership had the British in America behaved so badly. Bougainville's force, which had retired again upon Cap 


\section{9] PANIC OF THE FRENCH}

Rouge, had increased, according to French writers, to 3,000 men. There had been, moreover, 1,500 good militia inactive on the Beauport lines, to say nothing of the garrison of the city, while in Vaudreuil's fugitive army there could not have been much less than another 3,000 soldiers, and in great part good ones. The British army before the city walls was reduced by casualties to under 4,000. Wolfe's total losses, prior to the battle, in killed and wounded and sick, had been 1,500. There were probably 2,000 efficient men on guard at the camps, hospitals, and batteries below Quebec, which were liable to attack at any moment from bands of guerillas. Townshend could hardly have drawn seriously on this reserve, and we may therefore picture him, with his small army and a few sailors who had assisted in hauling up his guns and stores, busy for the moment with pick and shovel upon the Plains of Abraham. The desertion of many thousand militia is allowed for in the above estimate of the French, which is, in fact, their own. Comment is needless. Panic is spelled in every line of it, but it must always be remembered that the author of the panic was the young hero now lying dead in the cabin of the Sutherland.

Lévis, when he reached Jacques Cartier, breathed some heart into Vaudreuil's demoralized army. A hundred mounted men with sacks of meal were despatched in haste by a circuitous route to Quebec, with instructions to Ramezay to hold out, for help was coming. The troops themselves marched upon the 18th. They were to pick up Bougainville at Cap Rouge, and would then far outnumber the British. But that night, when still fifteen miles from the city, the news reached them that it had fallen. 


\section{SURRENDER OF QUEBEC}

There is not much to be said of the four days which Townshend and his troops spent upon the heights before Quebec. He extended his lines down to the St. Charles, and pushed his trenches close up to the walls. Within the city all was wretchedness, recrimination and despair, save for a small body of gunners, who pounded the British trenches with commendable spirit, but with little effect. On the evening of the $17 \mathrm{th}$ some threatening movements of the English ships and troops put a finishing touch to the futile and vanishing courage of the feeble garrison. Their officers, and small blame to them, refused to fight, and told Ramezay, a gallant old gentleman with a good record, that it was not fair to expect them to sustain the assault of a disciplined army from which their own, though far superior in numbers, had fled. There was a doughty, if unreasonable, town Major, however, one Johannès, who waxed indignant at such sentiments, and emphasized his indignation with the flat of his sword. But it was of no avail. Ramezay had no choice but to hoist the white flag, though the devoted Johannès, who surely deserves to be remembered at such a moment, instantly hauled it down again. He was alone in his protests, but eventually consented to go himself to Townshend with an offer of capitulation. It seems that, by making subtle efforts to spin out the negotiations, he defeated thereby his own object by wearing out Townshend's limited stock of patience, since all the satisfaction he could bring to Ramezay was that if the place were not delivered up by eleven o'clock it would be carried by storm. Ramezay signed the articles submitted to him, and they were in Townshend's hands by the time agreed 


\section{9] LEVIS ARRIVES TOO LATE}

upon. He had scarcely received them when Lévis' light horse with the meal bags rode in to say that succour was coming. Ramezay, however, with an honour that does him credit, refused to cancel an agreement on which the ink had scarcely dried. The terms were favourable, for Townshend's position was none too secure, and without loss of time he marched his army into the ruined town, which had yet another siege to endure, though its details have been hopelessly obscured by the glamour of the first one. It will be our duty in the succeeding chapter to say something of an episode in British history that is not without honour, but, for the reason, no doubt, just mentioned, is utterly without fame.

In regard to this memorable 18th of September it only remains to tell how the re-invigorated French army learnt that night at St. Augustin that they were too late, and that the Union Jack was already floating over the ruins of the proud city which for a century and a half had been almost more French than France herself.

Of the still more famous 13th of the same month what more can be said? It is my business to follow out the campaign to its termination, and in so doing to seem, perhaps, a destroyer of landmarks, a disturber of time-honoured traditions. I should like, however, so far as my own study of these wars teaches me, to endorse rather than to disturb ancient landmarks. The fight upon the Plains of Abraham, beyond all doubt or question, settled the fate of Canada, and eliminated the Frenchman as a governing factor in the life of the western continent. It did yet more, for if the republic of the United States was born at Yorktown, its seeds were surely sown 


\section{REJOICINGS IN ENGLAND}

$[1759$

on the plateau of Quebec. In all history there is no more dramatic episode; at the same time it would be hard to name one that had more influence on the future of the world.

The infinite significance of the achievement was, of course, in great part hidden from the eyes of those who shared in or applauded it. But the immediate value of the victory was patent enough to the meanest intelligence. When the news arrived in England, following so closely as it did on tidings of a disheartening kind, there was an outburst of enthusiasm that, though tempered in one sense, was in another stimulated to an even greater excess of emotion by the victor's glorious death. All England blazed with bonfires and resounded with pealing bells, but the grief for Wolfe, mingled with the sounds of triumph, Burke tells us was most noticeable. "The loss of a genius in war is a loss that we know not how to repair." "The people," says Walpole, "triumphed and wept; for Wolfe had fallen in the hour of victory! Joy, curiosity, astonishment were painted on every countenance. Not an incident but was heroic and affecting!" The recent doubters abased themselves, the tongues of envy which had freely wagged were silenced. Townshend, who failed significantly to do full honour in his despatches to his dead rival, was driven amid much obloquy to defend himself in print, which he did but tamely. The affection with which the army he commanded regarded their fallen chief could be instanced by a flood of written testimony: "Our joy is inexpressibly damped," wrote Knox on the evening of the 13th, "by the loss of one of the greatest heroes that this or any age can boast of." 
But all further eulogy on Wolfe must be resisted. Though the crucial blow of the war had been struck and the striker was dead, there was yet much to be done and much even to be suffered before the end came. For the present, seeing we must return later to Quebec, it will be sufficient to state that Murray was left in command of the shattered city with almost all the troops that survived the campaign, and that on October 17th Admiral Saunders and his ships sailed for England, carrying with them the embalmed body of the dead soldier whose endeavours they had from first to last so loyally seconded.

The Royal William, bearing the remains, arrived at Portsmouth on November the 17th. Amid the firing of minute guns from the fleet, the tolling of muffled bells, and the hushed silence of a vast concourse of spectators, the funeral cortége wound its way through the town on the long road to London.

Wolfe was laid by his father's side in the family vault at Greenwich church, while the bulky monument in Westminster Abbey commemorates a nation's gratitude if it does no great credit to its taste.

While, with 8,000 men, Wolfe had gone to encounter Montcalm and Lévis, and take Quebec, Amherst, with almost as many good troops and 5,000 provincials in addition, had proceeded against Bourlamaque, who, with what forces could be spared from the main army, was to defend the Champlain route to Canada. That Wolfe succeeded and his chief failed is a fact of history that, reduced to bare figures, creates an unfair inference. The former won success by genius and dash which we may almost fancy compelled the assistance which an admiring fortune gave 
him. The latter failed from the lack of such inspiration as is heaven-born and given to but a few. He was thorough, and careful, and made almost no mistakes; but he had great difficulties to contend with, and did not succeed, this year at least, in attracting the smiles of fortune.

Amherst was, in truth, a good soldier and a man of tact as well. He was well liked in America, though he had to face the bad odour which the hapless Abercromby had left behind him. This, however, in the provinces which had reason to complain, he had no difficulty in surmounting. It was in those rather who had none, but on the contrary owed their deliverance from three years of frontier war, and misery and massacre, to the self-sacrifice of Forbes, that obstruction and discontent met his friendly overtures.

In Philadelphia, where the brave Scotchman had just laid down his life, and whither Amherst went early in the year to talk about reinforcements and Indian affairs, he found no gratitude whatever for the routing of the French and Indian upon the longharried Pennsylvania border. There was much grumbling at having to shelter the troops who had fought and bled for them, and still more because government had not yet met the claims of teamowners and hucksters, whose impositions the honest Forbes, it will be remembered, had denounced in unmeasured terms. The fact was, that every one in government employ in America, from Amherst and Wolfe down to the meanest private, had to wait for their money. It was a time of supreme effort and self-denial, and a moment well worth it, if ever there was one. Still it was aggravated by scandalous 336 


\section{9] WASHINGTON RESIGNS}

negligence on the part of Barrington, the English Secretary for War. Amherst was immensely hampered, and had to occupy himself in urging the provincial governments to temporary financial expedients, which was not easy, as the credit of the imperial government had suffered greatly.

After finding the garrison for Fort Pitt, as Duquesne was now called, and that of a few smaller posts, the southern colonies, freed at length from all fear of French or Indian, relapsed into their wonted calm of tobacco-planting, visit-paying, fox-hunting and mild wrangling with their governors. They appear no more in this war, in which they had indeed figured somewhat poorly, while their borderers, who were for the most part a race unto themselves, set to work to re-occupy the ravaged districts along the Blue Ridge and the Alleghanies. Washington, with no further prospect of active service, now retired to matrimony and country life. He had gone straight to Virginia off the long and arduous return march with the dying Forbes, accompanied, by several of his friends among the British officers, and married in their presence the handsome and well-dowered widow, Mrs. Custis. He was personally thanked for his past services by the House of Burgesses, and his inability to reply to the Speaker's eulogistic address drew from that gentleman a happy remark, which, together with the incident, has become historic: "Sit down, Mr. Washington; your modesty equals your valour." Remembering Washington's outspoken criticisms of his legislature and the feeble support it had given him, one might well imagine that his heart was too full for words, and as a simple, straightforward man, he considered that the less said the better. 


\section{RENEWED ACTIVITY}

Pennsylvania in the meantime was so backward in voting the troops Amherst asked for that he threatened to remove all the garrisons from her frontier, a threat which brought matters to a speedy and satisfactory conclusion. For it must not be forgotten that there was a sturdy minority, even in Philadelphia, who had felt bitterly the part played by the Legislature, while the Western Counties had on one occasion threatened to march upon the city and compel the House to take military action. The Northern Colonies, on the other hand, swallowed the memory of Abercromby, made the best of financial difficulties, and came forward handsomely. New York found 3,000 men, and even little Jersey, almost the only provinee without an exposed frontier, supplied a regiment a thousand strong, while New England, as usual, was in no way backward.

Colonel and Brigadier Prideaux, who had just landed, was to lead a force up the Mohawk route, rebuild Oswego and attack Niagara. Amherst himself, as we know, was for the Northern road. Albany was the starting-point for both armies, and once again when the ice melted and the spring opened it resounded with the din of arms, and the thrifty Dutch traders reaped the harvest that of necessity accrued from the prolonged presence of nearly 20,000 armed men. Once more the rough forest road from Fort Edward on the Hudson to Lake George was beaten hard by a steady stream of marching troops, of guns and wagons, and the old trysting place at the lake head was again gay with tents and varied uniforms, and the bay itself dark with boats. Amherst had collected here 6,000 regulars and nearly 5,000 provincials. There were 2,000 Highlanders. with the 


\section{9] CAPTURE OF TICONDEROGA}

17th, 27th, 53rd regiments, and 1st battalion of the 60th, besides light infantry under Gage; Rangers, who now ranked as regulars, as well they may have, and the usual small complement of artillerymen.

The inevitable delays in mustering and provisioning the colonial troops had occurred, and it was the 20 th of July when another pageant, no less gorgeous than that of Abercromby in the previous year, and with more hopeful prospects, floated down the lake. The troops landed without opposition on the east bank of the river outlet, and marched without hindrance across to the saw-mills whence Abercromby had delivered his ill-timed and ill-fated assault. Crossing the stream, the scouts found the famous redoubt of Ticonderoga stronger than ever, but to their surprise unoccupied. Bourlamaque was stationed here with nearly 4,000 men-more, in fact, than Montcalm had used on the same spot with such deadly effect. But Amherst was not Abercromby, as Bourlamaque knew very well, and would have knocked those wooden walls to pieces in an hour. The French were in the stone fortress on the point. The preliminary operation of a siege, with some little skirmishing in the woods which were full of French Indians, went on. Bourlamaque, however, was under orders from Vaudreuil to make his stand at another point. So on the night of the 26th, he and his garrison embarked quietly on the lake, abandoning the fort. After the last man had left, a dull roar, followed by a tremendous explosion, burst on the summer night as part of the masonry of the fort was hurled skywards. Sheets of flame flared from the débris making a grand and awful spectacle, while against the light of the flames the abandoned French 


\section{CROWN POINT ABANDONED}

flag was seen streaming in the wind. A sergeant of Gage's corps, with four privates, rushed forward and achieved the perilous task of snatching the trophy from the blazing buildings. Thus, in dramatic fashion, fell Ticonderoga, for years the armed gate of Canada, the barrier to invading armies, and the scourge of the Northern frontiers, as Duquesne had been to those of the lower colonies.

The French had temporarily retired to their second fort at Crown Point, ten miles down the lake, and Amherst in his deliberate fashion followed them, but only to find this also gutted and abandoned. Bourlamaque had carried his army to the extreme end of Lake Champlain, and, according to his instructions, prepared to resist Montcalm at the île-aux-Noix. This last was an island in the centre of the Richelieu River, the waterway to Canada and a position of great natural strength. But in spite of the numbers and spirit of his force, and his own skill, Amherst was now stopped by an obstacle, small enough in itself, but insuperable. This was the presence on the lake of four vicious little French vessels, armed with cannon and manned with sailors. Amherst had nothing to cope with them. It is often said that as their existence was no secret, he should have provided himself with a superior armament, building it on Wood Creek early in the season. But it was too late for regrets; he had now to sit down and create his little fleet with the sole assistance of the historic but inefficent saw-mill near Ticonderoga.

It was now only the beginning of August, and his ships were not finished till the middle of October, by which time there was little hope of reaching Canada, and none whatever of assisting Wolfe, of whom no 


\section{9] A ROMANTIC FORTRESS}

news had come. Three messengers had been sent to him : one of them had got through, but the others were caught and sent to Montcalm. Amherst had a passion for fort building, and having patched up Ticonderoga, he decided to restore and enlarge Crown Point, which, standing out on a promontory at the narrowest part of the lake, was eminently the key to the whole situation. Three thousand men were now set to work upon the fortress. Others worked upon the ships. The remainder practised their manœuvres or fished in the lake, while the Rangers, under Rogers, scoured the woods.

Our invaluable traveller, Dr. Kalm, had been staying at Crown Point a few years earlier in the piping times of peace, as a guest of the commandant, $M$. Lusignan. He gives a delightful account of the almost idyllic life led by the garrison at this romantic spot. The fort, he tells us, was a quadrangle with high stone walls, rendered still more formidable in some parts by the steep rocks over the lake on which they stood. At one end was a high stone tower mounted with guns from base to summit while in the enclosure were excellent stone houses for the men and officers and a chapel. On the shore adjoining the fort were cleared fields, where the garrison cows wandered and where every private soldier had his garden. The commandant was a man of culture and varied information. The soldiers, though in no way disrespectful, seemed on the friendliest terms with their officers. They were sufficiently paid and admirably fed, for the woods were full of game, the lake of fish, and a holiday could always be had for the asking. The men served till they were forty or fifty years old, when, as we know, the king presented them with a 341 


\section{NEWS FROM NIAGARA}

farm and provided them with food for the first two or three years, and sometimes even with a wife. The learned Professor gazed with admiration at the lofty wood-clad masses of the Adirondacks behind the fort, and marked across the lake the long, level plain of then virgin forest, backed by the swelling ridges of the green mountains, from which the State of Vermont took its name. He rambled everywhere, noting birds and flowers and trees and rocks, these things being his immediate business. He also tells us of a stone windmill, mounted with cannon-so placed as to command a splendid view of the water towards Ticonderoga-whence the hostile barks of the British or their Iroquois allies could be seen approaching. All this was in 1749, and though blood enough had been shed even then along these lakes, neither the Doctor nor his host could have guessed what warlike pageants and stirring scenes they were yet to witness.

News came to Amherst in August of the capture of Niagara and the death of Prideaux, upon which he at once despatched Gage to take command. The two months at Crown Point were not wholly inactive ones. They were marked, at any rate, by one of the most sensational pieces of dare-devil enterprise that even Robert Rogers ever achieved.

Now there was a large settlement of Abernakis Indians on the St. Francis River about 180 miles north of Crown Point, near Montreal, and far in Bourlamaque's rear. They had been settled there for several generations under the protection of the French, and were what the Canadian Church was pleased to call Christians, observing, that is to say, in ignorant fashion, the mere outward forms of the Roman Church, 


\section{9] ROGERS' EXPEDITION}

but in practical Christianity being no better than the darkest western savage. Perhaps they were even worse as inter-tribal obligations had been cast off, and they had no limitations to their lust of blood. They were invaluable, however, to the Canadians, and the scourge of the New England frontier. Rogers set out on September 13th with 230 picked men, to read them a lesson. "Take your revenge," Amherst told him; "but though these villains have promiscuously murdered our women and children of all ages, it is my orders that none of theirs are killed or hurt."

Rogers and his party stole along the western shore of Lake Champlain in whale boats, unobserved by the French cruisers, as far as Missisquoi Bay, 90 miles to the northward. There he hid his boats, leaving some friendly Indians to watch if they were discovered, and bring him word. He had now another 90 miles to march through the trackless forest, overlapped upon every side by enemies. His Indian watchers soon overtook him with the information that his boats were destroyed, and that a large force of French were in hot pursuit. With this crushing blow the courage of Rogers and his men rose rather than fell. They determined to press on, keep ahead of their pursuers, destroy the Indian hornets' nest at St. Francis, and then, sweeping to the eastward, make for the frontier of New England. Perhaps a closer knowledge of local topography, and of the then state of the country, than could be expected of the general reader is required to quite grasp the daring of Rogers' exploit and the woodcraft that made it possible. He sent a message back to Amherst to forward provisions to a certain spot on the Connecticut River, and then he and his men toiled on for ten days through some of the 343 


\section{ABERNAKIS SETTLEMENT DESTROYED}

densest swamps and forests in North America. When they reached the St. Francis River the current was swift and chin deep. All of them, however, but a few British officers, volunteers, were hardened backwoodsmen, and linking arms, they reached the further bank in safety, though with great difficulty. Soon afterwards, Rogers climbed to the top of a tree, and espied the Indian village three miles away, nestling amid the woods in supreme unconsciousness of its impending fate. Secreting his men, he himself crept to the edge of the settlement, and found the whole population absorbed in one of their characteristic festivals, a mad orgie of dancing and clamour. Creeping back to his force, which by sickness, death, and hardship had been reduced to 142 , he lay with them in hiding till the dark hours of the morning. Then in a half-circle they silently advanced upon the town, now wrapt in sleep more profound than common from the exertions of the previous evening. At a given signal from Rogers the whole band rushed upon the cabins and wigwams. The surprise was complete. There were about $200 \mathrm{men}$ in the place, nearly as many unfortunately, from Rogers' point of view, being absent on an expedition. Every one of them was killed. A few got away upon the river, but were followed up and slaughtered; though no women or children were touched. Five English captives were released, and 600 English scalps, torn from the heads of both sexes and all ages beyond the New England frontier, were found nailed to the doors of the houses as trophies. The Catholic Church, with amazing incongruity, rose in the midst of these unredeemed barbarians, three generations of whom its bell had rung to mass with laborious regularity. Such 
was the Christianity which satisfied the ethics of the French-Canadian priesthood of that day. Rogers burnt the whole village to the ground, including the church, and one can scarcely profess much compunction that the priest perished inside it. Only one man of the British force was killed and three or four wounded. It was now past sunrise, and the famous backwoods' leader learnt that there were 400 Frenchmen just in front of him, and 200 more on his flank. The whole army of Bourlamaque lay between him and Crown Point, 190 miles away, and he was half that distance over the Canadian frontier. If his boats on Lake Champlain had escaped notice, he would have got back without difficulty. As it was, however, the circuitous route to the Connecticut River, whither Amherst had promised to send food in case of accidents, was Rogers' only choice. Carrying such corn as they were able for their subsistence, these intrepid men eluded their swarming foes by a forced march of eight days through tangled swamps and wooded ridges. They traversed through blinding forests, what is now a fair and famous country, "the Eastern townships" of Canada, an old and highly developed settlement of purely British blood and origin, sandwiched between French Canada and the United States. Ultimately they reached the broad waters of Lake Memphremagog, so familiar now to the tourist and the sportsman. Here, running out of food, they separated into small parties, so as better to kill the game they stood in need of, but which proved woefully scarce. The adventures and sufferings of the various groups before the survivors reached the British lines, are among the thousand thrilling tales of border warfare. Many were killed, many taken 


\section{TO WINTER QUARTERS AGAIN [1759}

prisoners and carried off to the torture and the stake in Indian villages. The officer Amherst had sent with food to the Connecticut River miserably failed, for which failure he was cashiered. The despair of the ninety odd survivors at this moment was at its height, for a vast distance of wilderness had yet to be travelled. By Rogers' heroism and fertility of resource, however, the half-starved band were in one way and another got back to camp early in November. They had traversed over 400 miles, destroyed more than their own number of the foulest Indians in the north, and struck a blow that resounded through Canada. Amherst thanked them warmly. One does not hear that they received or expected anything more. It was all in the Rangers' day's work, and Rogers himself has left an account of the expedition.

Amherst, in the meantime, had completed his ships, and on the first venture they destroyed their French rivals. But it was now the middle of October, and the weather had broken: sleet-laden storms were lashing the surface of Lake Champlain into a fury, and winter was looming near.

Lévis, who had long since come from Montcalm, had helped Bourlamaque to make the passage of the Richelieu, to Canada impregnable under a long siege -and for that there was no time, since 100 guns securely entrenched defended the passage. Quebec, too, had fallen, which lessened the urgency, and lastly the service period of the provincial troops expired on November 1st. So the army, still shivering in its summer clothing, retired up the lakes, leaving strong garrisons at Crown Point and Ticonderoga, who sent salvoes of artillery echoing through the surrounding 
mountains in honour of the birthday, and as it so happened the last one, of George the Second.

Prideaux, the brigadier, whose mission it was to rebuild Oswego, take Niagara and ruin the French interest in those north-western regions over which their sway had been so long undisputed, was early in the field. He was at Schenectady on the Mohawk route late in May, and was joined by his Division. This consisted of the 44th and 46th regiments and 2,600 New York provincials. There were forts now at intervals the whole way from the Hudson to Lake Ontario, and his communications were thus secured against the cross-country raids from Canada, that had been the terror of those who travelled and those who lived upon this forest highway. Johnson was commissioned to seize this favourable moment of the waning of French prestige to stir up the Six Nations to their old enthusiasm for the British cause. The evervigilant backwoods baronet needed no pressing, but held in his lavish fashion a grand council, celebrated with meat and drink and eloquence at Fort Johnson. Five hundred Indians attended; not only representatives of the faithful nations, but of several others formerly hostile, who, wise in their generation, had read the writing on the wall. This time they sang the war song on the banks of the Mohawk with serious intent, and 900 warriors, at the response of their chiefs painted and be-feathered themselves for battle.

Prideaux and his men were upon the site of Oswego by the middle of June. Haldimand, the second in command, was given the task of rebuilding the fort. Like Bouquet he was a faithful and able Swiss officer, who had been imported to assist in the formation of that motley but now efficient corps, the Royal 
Americans. "He had helped to recruit it among Oglethorpe's Highlanders of Georgia, the Germans and Scotch-Irish of Pennsylvania, and the indented servants, poor whites and Huguenots of the two Carolinas. He has a threefold claim on England, but she has forgotten him. He was an indefatigable collector, and has left 232 volumes of contemporary papers bearing on this period to the British Museum, as well as the Bouquet papers, which were his property. His military services were considerable, and above all, he was Governor of Canada during the Revolutionary war from 1778 to 1784 -a sufficiently critical and conspicuous post at that time, which he admirably filled. Canadians complain, and justly so, that his memory is at least as worthy of preservation as that of provincial preachers and forgotten novelists, but that they look in vain through works devoted to cataloguing the illustrious dead for the name of this trusty servant of the British crown.

Prideaux left Oswego on July 1st. He had not been long gone when Saint-Luc de la Corne, the wellknown French partisan leader, seized the opportunity to attack Haldimand. He brought with him 1,200 men, mostly Canadian irregulars, and the notorious Abbé Picquet, with some of his so-called Christian Indians, whom he exhcrted to give no quarter to the British heretics. They did not have a chance, for though Haldimand's parties were wood-cutting outside the temporary entrenchment of pork barrels, they soon rallied to their lines. De la Corne's troops were not of the kind to assault redoubts. They confined themselves for some twenty-four hours to desultory rifle fire from the bordering woods, and when the guns which had been brought to bear on 


\section{9] PRIDEAUX ON LAKE ONTARIO}

them opened from the entrenchments, they were seized with a panic and raced helter-skelter for their boats, knocking over the reverend Abbé in their haste. Some thirty of them were killed and wounded, among the latter being La Corne himself. Haldimand was henceforward left in peace, and in due course a new fort arose upon the site of Montcalm's first Canadian victory by Lake Ontario, which in after years became the familiar quarters of many British regiments.

Prideaux, in the meantime, with Sir William Johnson and his Indians, was hugging the southern shores of Lake Ontario in boats and batteaux mounted with guns. The coast line to the outlet of the Niagara River, where the fort stood, was over seventy miles. There was a French warship cruising on the lake, which is here about the breadth of the English Channel at Brighton, so it was slowly, and with due caution, that the unseaworthy flotilla crept along the low shores, in these days so instinct with vigorous humanity, in those presenting to the restless lake a continuous background of silent and sombre woodland.

Captain Pouchot, of the regiment of Béarn, was in command at Fort Niagara, an excellent officer, and one of the many combatants in this war who has left memoirs of it. The Indians for once-a sign of the change of times-had failed the French as newsbearers, and Pouchot was taken by surprise. Some of his men were absent, and his garrison reduced to less than 600 all told. At the very head of the Ohio watershed, near Lake Erie, there were still some small French posts, and Pouchot now sent to these for assistance. Many of the French guerilla leaders, with 


\section{NIAGARA}

wild, miscellaneous bands of followers, were yet stirring in this dark country, in vain hopes of dashing down and catching Fort Pitt, now garrisoned with Provincials, unawares. It was to some of these that Pouchot now sent, and they hastened to his succour.

The old fort at Niagara stood on much the same site as the present one, in the angle, that is to say, where the river meets Lake Ontario. It was large, substantial, and well armed, as became the portal and defence of the illimitable trading country behind. Prideaux had over 2,000 men with him, besides Johnson's 900 Indians. One-half of his force guarded the boats, the other was free for the attack. The Engineers, like Abercromby's, proved incompetent, and their first trenches were untenable. "Fools and blockheads $\mathrm{G}-\mathrm{d} \mathrm{d}-\mathrm{n}$ them," was the written criticism of an indignant Highland officer. When fresh approaches were constructed and the British guns opened fire a still worse thing happened, for a shell burst on leaving the mouth of a coehorn and instantly killed Prideaux, who was standing near. Johnson now took command, and the batteries were actively served. In a fortnight the walls were badly shattered, over a hundred of the small garrison were killed or wounded, and Pouchot realized that nothing but immediate succour from the West could save him. On the 24th Johnson's scouts reported that a French force was approaching from above Niagara Falls. He therefore pushed forward during the night some light infantry, Grenadiers, and part of the 46th regiment. They took up their position in the immediate path of the approaching French, just below the mighty cataract. In the cool of the morning De Ligneris, Aubry Marin, de Répentigny, the cream, in 


\section{9] DEFEAT OF THE FRENCH}

short, of the Canadian backwoods leaders, with a wild following of 1,200 men, came down the portage road from above the Falls. The force included the small garrisons at Venango and Presqu'île, with a horde of fighting traders from Detroit, the Illinois, and the West, truculent, ill-favoured men who lived among the Indians, and, like them, went to battle, strung with beads and quills, and smeared with paint and grease. They were brave enough, but the banks of the river above the rapids had been cleared. It was an open, not a woodland fight, though, indeed, long years of practice had made even the British linesmen no mean performer among the trees. Here, however, he was in the open and flanked by a band of the Iroquois, the finest of savage warriors. The French threw themselves with undisciplined courage and loud yells upon the British front. The linesmen received them as Wolfe's troops on the Plains of Abraham six weeks later received Montcalm's assault with a steady, withering fire. They had enough men here, however, for a flank attack, which was carried out by the Indians and light infantry with deadly effect. In an hour the broken column of white savages and bushrangers was flying back in wild disorder past the Falls, and the long stretch of rapids above them, to where their canoes were waiting, in smooth water, to bear them back into Lake Erie, whence they came.

Two hundred and fifty of the Ohio garrison troops alone had been killed or wounded in this affair, besides numbers of their regulars. All the chief officers were taken prisoners-de Ligneris, Marin, Aubry, de Montigny, and de Répentigny, with many more.

While the fight was in progress up the river a French officer thought the British trenches were un- 


\section{SURRENDER OF FORT NIAGARA [1759}

guarded, and a sortie was attempted. It was led by de Villars, the captor of Washington, in his youthful essay at Fort Necessity. But as the French approached what had seemed empty trenches, a line of bayonets, those of the 44th, under Col. Farquhar, suddenly flashed in their faces, and de Villars fell back, according to his orders rather than to his inclinations, for though he belonged to a type whose failings were many, lack of courage was certainly not one of them.

There was nothing now for Pouchot but capitulation. Major Hervey, of the Bristol family, was sent by Johnson to demand it, and from him the Frenchman learnt for the first time the full extent of the recent defeat. $\mathrm{He}$ would scarcely believe that all these redoubtable partisans were prisoners in Johnson's camp till, at Hervey's request, he sent a witness to verify the fact. This settled the matter. Johnson practically made his own terms, though the "honours of war" were conceded in recognition of the gallantry of the defence. Over 600 prisoners were sent to New York, the women and children to Canada. Fort William Henry was again in the minds of the garrison, and most urgent appeals were made to Johnson for sufficient safeguard against the Indians. This, it need hardly be said, was given, a matter of course, but a weaker man than Johnson would have found difficulty in controlling the plundering instincts of his fierce allies. Everything, however, went smoothly, and the fort, with its forty guns, ammunition and stores, was quietly occupied by the British.

When Johnson returned to Oswego a little friction arose between Haldimand and himself as to the chief command. It was effectually settled, however, by the 
arrival of Gage from Crown Point, who superseded both. Gage's instructions were to attack the French posted above the first rapids of the St. Lawrence on the way from Lake Ontario to Montreal. He effected, however, nothing of any practical value in that direction. It was reserved for Amherst himself, in the following season, to make the descent of the St. Lawrence, and with it the final move in the long game. With the British in possession of Niagara and Oswego, the French flag finally disappeared from Lake Ontario and its shores. Their western posts at Detroit and the Illinois, as well as the smaller and remoter ones, were isolated by this severance of the main artery, and could only be approached by the tortuous water-ways, even now only known to the sportsman and the lumberman of the far back country of Ontario. General Stanwix, in the meantime operating from his base at Fort Pitt, with 4,000 men, had not been idle. He had clinched the new relations with the Ohio tribes, and had eventually occupied every fort to Presqu'ile on the shore of Lake Erie. The main trunk of French Dominion was being girdled by the British axe, and its far-spreading limbs, which brushed the distant prairies of the North and crossed the sources of the Mississippi, must now perish from lack of nourishment. One more stroke, and the hardy growth of empire would shrivel up and die, and this was to be aimed by Amherst at Montreal. 


\section{CHAPTER XII}

M

URRAY, when he sat down with his small army to face the fierce Canadian winter amid the ruins of Quebec, had no light task before him. He had the certain prospect of seven months' complete isolation from everything but a vigilant and hardy enemy, smarting under the bitterness of defeat. But he was a good soldier, a son of Lord Elibank, young and tough, brave and generous, and better fitted for the work in hand than Townshend, who gave it over to him and returned to England, we may well believe, without a pang. Murray was left with a little over 7,000 men; but the strength was regulated rather by the number he could feed than the number he could muster. The surrounding country had been swept nearly bare by the needs of Montcalm's army, and Murray had to depend almost wholly on his own stock of provisions and the little that was found in Quebec. No relief of any kind from any quarter could reach him until May.

Such of the French garrison as were prisoners of war had been sent to England with the fleet, while all the militiamen who chose to give up their arms and swear allegiance to King George were allowed to return to their homes. The civil population of the city had been scattered over the country by the siege. There was little temptation, or indeed encouragement, for those who could avoid it to return now, and 354 
Murray had perhaps some 3,000 citizens all told upon his hands. During the moderate weather of October and November there was an enormous amount of work to be done. There was no money nor any winter clothing, thanks to Lord Barrington, nor could either be now obtained. Murray was compelled to borrow money from the officers and men of the army, who responded generously ; Fraser's Highlanders, we are told, being enabled by their "sobriety and frugality" to be especially forward in this matter. Quarters had to be rigged up out of the shattered houses, churches and convents, in preparation for a fiercer winter than even those troops inured to American winters had ever yet faced, while the officers put up with such accommodation as they could find. Knox tells us that he was fortunate in getting part of a stable where, with the help of a Canadian stove-even then a universal necessity-he contrived to keep himself warm. He was detailed on duty for a time to the general hospital in the suburbs, where French and English wounded were lying in great numbers under the charge of the nuns of the Augustine order. He writes with rapture of this fine building, and waxes enthusiastic on the perfect order and cleanliness he found there, and the devotion of the Sisters, who were as untiring in their care of their late foes as of their own people. Each wounded officer had a room to himself, while the men had clean, comfortable beds in sweet and well-aired dormitories. It was no wonder, he tells us, that the poor English soldiers were glad to be transferred from the wretched regimental hospitals of the army to such a haven of rest. Knox dined every night with the French officers and merchants who, from various causes, 


\section{SPIRITS OF THE FRENCH WOMEN [1759}

were attached to the hospital. Many ladies, too, enlivened these social occasions with their presence, and amazed him with their cheerfulness at a moment so disastrous for their country and fortunes. When, however, the subject was touched on they fell into a spasm of melancholy, "uttering deep sighs and expressions of heartfelt sorrow." As Knox understood French, the gentlemen, not, as our author remarks, in keeping with their "boasted politesse," conversed frequently in Latin. The gallant major, however, was quite equal even to this emergency, and one day dropped a bombshell among the dismayed Frenchmen in the shape of a pertinent quotation from the Georgics, taking care to pronounce it as well as he could after their fashion.

Not only Knox, but an officer of a Highland regiment wrote in surprise at the buoyant tempers of the Canadian ladies. "Families whom the calamities of war have reduced from the height of luxury to the want of common necessaries, laugh, dance and sing, comforting themselves with the reflection, Fortune de guerre. Their young ladies take the utmost pains to teach our officers French; with what view I know not, unless that they may hear themselves flattered and courted without loss of time."

The rage against Vaudreuil was very great among the citizens of Quebec, especially the women, and found vehement expression in the wish, "That he may suffer as miserable and barbarous a death as ever European suffered from the savages."

Murray issued a proclamation to the Canadians, which was posted on the door of every parish church. He pointed out to them that he had a veteran army in the heart of their country, that the sea was closed 


\section{9] MURRAY'S PROCLAMATION}

to them, and that their cause was hopeless. He begged them to think of the welfare of their country, and not of useless glory. The English people were ready to embrace them as brothers, and give them a freedom which they had never known under the despotism which hitherto distinguished the government of the country. He was prepared to protect them against the savages who Vaudreuil, having himself fled before the British arms, now incited to murder the people he had abandoned because they wished for peace. The Canadians must now see how false were those who told them that the British were devoid of clemency and humanity, and how grossly they had been imposed upon. Having, therefore, no more hope in arms and no further excuse for taking them up, the British would visit those who did so with the just vengeance that was the right of victorious soldiers who had held out to them the hand of peace and friendship. The oath of allegiance was administered to the whole country east of Quebec. Those parishes that deliberately broke it were liable to severe punishment, and a few examples had unhappily to be made.

Lévis, in the meantime, kept a considerable army in garrison between Jacques Cartier and Montreal, while his Indians and Rangers lurked continually in the actual neighbourhood of Quebec. Occasional stragglers were cut off, and wood-cutting, one of the most vital operations of the winter, had to be carried on under armed escorts. There were no horses left, and continual processions of sleighs, dragged by soldiers and loaded with cord wood, went backwards and forwards over the four miles between the city and the forest of Saint Foy. 


\section{INCREASING SICKNESS}

The defences of Quebec on the west side were feeble, and the frozen ground effectually prevented any intrenching work being done outside the walls. Murray fortified and occupied with a strong guard, constantly relieved, the churches of Saint Foy, three miles, and Lorette, twelve miles distant, in the direction of Montreal. This prevented all danger of a surprise at any rate, and the air was thick with rumours that Lévis, with 10,000 to 15,000 men, was meditating an assault. The French commander had, indeed, plenty of men, but very little food for them, and it taxed all the resources of Bigot, who was at Montreal, to find them a bare sustenance.

The chill of October gave way to the cold of November, and as Christmas approached the full rigour of the Canadian winter struck the thinly clad, ill-fed troops with dire effect. Frost-bitten hands and cheeks and feet was the common lot of the sentries on the numerous guards which it was necessary to post in every quarter of the city and its outskirts. The officers, says Knox, who could, of course, procure wraps, became unrecognisable to each other, as, buried in rugs and furs, they went about their business at a run, and too fast to admit of the ordinary salutation that courtesy demands. But frostbite gave way to even yet more serious evils, and the sick list lengthened with formidable rapidity. Exposure and an unalleviated diet of salt meat played havoc with the men of all ranks. On Christmas Day the garrison had sunk, from the various drains upon it, to 6,400 men, 1,400 of whom were in hospital, and it became infinitely worse later on. The spirits of the troops were excellent, but discipline relaxed under the continual privation without the stimulus of 
fighting, and aided somewhat by the fact that liquor was the only thing in the city that was not scarce. Beleaguered as effectually by nature as if hemmed in by armed hosts, and perched on its white throne, all glittering in the bright but impotent sunshine of a Canadian winter, the captured city, with its roofless churches and shattered houses, was in a sorry plight. The inhabitants, whose hours of going out and of coming in, Murray, in his critical position, was compelled to regulate, suffered even more than the soldiers, for most of them had lost their all. Punishments of British soldiers for theft or outrage or infringement of rules were prompt and seem savage enough too, for one reads again and again of 1,000 lashes sometimes "reduced to 300 on account of the severity of the weather." Now we hear of a Frenchman executed for inciting to desertion, and now of two British soldiers condemned to death for robbery: but the sentence is mitigated to one only, upon which we are shown a grim spectacle of the culprits throwing dice for death or freedom, and learn that eleven was the winning throw. Two women are flogged through the town for selling liquor without leave, and an officer and forty men blown up in an abandoned French ship which they were scuttling. Occasional skirmishes between New England Rangers under Captain Hazen and French guerillas on the south shore of the frozen river break the monotony of suffering and sickness. Vaudreuil surpasses himself in the reports he sends down the river. "The Grand Monarch," he assures the credulous Canadians, "has sunk, burned and destroyed the greatest fleet that ever England put to sea; made an entire conquest of Ireland, and put all the troops and natives who were in arms to the sword; so that 359 


\section{HEAVY MORTALITY}

the next ship will certainly bring us an account of a peace being concluded. Quebec will be restored, and Canada once more flourish under a French government."

But the incidents of this somewhat unique experience of a British army, isolated in the interior of a hostile country under a semi-arctic winter, excellent reading as they are in the letters of those who suffered or laughed at them, must be treated with scant notice here. Sickness and suffering, though cheerfully borne, was unhappily the chief feature of this bitter winter, and that most of it was due to the neglect of a department which, with the experience of Louisbourg and Halifax, had no excuse, is sad to think of. By Christmas 150 soldiers had died; in the next two months 200 more succumbed, and by the end of April the grand total was no less than 650, nearly all victims of scurvy, dysentery, and fever. Most of the bodies lay above ground, and frozen stiff, awaiting burial till graves could be dug. Murray's effective force dropped to about 3,000 men, while the strangest part of the whole business is, that out of 600 British women attached to the army, not a single one died, and scarcely any sickened !

Point Lévis church, now only a mile across the frozen river, had been fortified and garrisoned, and had already once repulsed the French advanced parties. St. Foy and Lorette too had been strengthened, and Lévis' rangers, skirmishing for food and intelligence, had been punished there on more than one occasion. Spies and news-bearers went freely backwards and forwards. As the winter waned, Murray heard that Lévis was of a certainty coming to assault the city, that his army had been supplied with scaling ladders, 
and was being exercised in their use upon the church walls of Montreal, to the great injury of the men's limbs and the great diversion of the ladies, who, from all accounts, were even less depressed than their sisters of Quebec. Every one, however, felt that the crisis would be solved by sea, rather than by land, and the fleet which first ascended the St. Lawrence in the spring would be the determining factor in the possession of Quebec. February passed away, and with March the fierce cold of midwinter relaxed. But it was not till April that the melting ice and snows in the milder regions of Upper Canada began the great upheaval of the frozen surface of the St. Lawrence which marks the close of winter.

Lévis now began to move. Difficulties of transport without horses had compelled him to relinquish all thoughts of a winter attack upon the town. There were still the French ships in the upper river, which, it will be remembered, had retired up the tributaries the preceding summer before Saunders' fleet, and upon these he depended when the ice had broken to descend upon Quebec. Full accounts of the sickness of the British garrison and its dwindling numbers had been brought to Montreal. And Vaudreuil, whose arithmetic always tallied with his wishes or his vanity, subjected the English forces to the process of division, weak as they truly were, instead of multiplying them by three, which was his usual custom after either victory or defeat. He was naturally anxious that every effort should be made to recover the capital, and it was not his part to lead the troops into the deadly breach.

On the 18th of April the British learnt definitely that they were to be attacked, with " the whole force 


\section{APPROACH OF THE FRENCH [1760}

of Canada"-that two months' provisions and a supply of brandy for the regular troops had been especially stored for this supreme effort, and that the French ships were to co-operate. On the 21st, Murray ordered all Canadians, except nuns, out of the town at three days' notice, giving them facilities, however, for storing and guarding their property. Full sympathy was felt for these poor people, but 3,000 British soldiers, with as many invalids behind them, stood face to face with such strength as all Canada, with a brave and resourceful general, could command, and there was no room for sentiment. The fugitives, as they left the city, upbraided the English for breaking the conditions of the capitulation, assuring them that the approach of Lévis was a false alarm which, if their information had been trusted instead of that of scouts, deserters and spies, would be readily recognised. The sequel showed the value and the justice of such worthless recriminations. Six days afterwards, Lévis, with an army of over 7,000 men, arrived in front of the British outposts at Lorette. He had reached Pointe aux Trembles, close to Jacques Cartier, on the 26th, with his ships, supplies and troops. Thence, despatching his vessels down the river, he had marched by an inland route, crossed the stream of Cap Rouge some miles above its mouth, and appeared before Lorette, the English outposts at the same time falling back upon St. Foy.

This night the most appalling thunderstorm that had been known for years lit up a gloomy prospect of melting snow and thawing ice-fields and dripping woods. Above it all, in the glare of the lightning flashes, the battered towers and gables of the longharassed city rose above the surging river, still gurg- 


\section{0] A TIMELY WARNING}

ling and choking with the fragments of its wintry load. When the thunder ceased, a tempest of unusual fury burst from the south-west. Waves, winds and ice-floes raged together in furious combat from Cap Rouge to Point Lévis, and from Point Lévis across to the island of Orleans and the shallow strands of Beauport, while the Montmorency flung over its dark cliff into the chaos below the foaming waters of a hundred fresh-loosened streams. In the dark hours of this wild night a French soldier was drifting down the St. Lawrence upon an ice-floe, expecting every moment to be his last. He was whirled along past the cliffs which Wolfe had climbed, past Cape Diamond and Point Lévis, and onwards to the island of Orleans. Then the swift tide turned and washed him back, by a piece of good fortune, to where the only British ship, the Racehorse sloop, that had wintered in the river, was anchored in the slacker water below the town. Here, by almost a miracle, he was seen and rescued, more dead than alive. It was two hours before the exhausted Frenchman could give an account of himself, which was to the effect that he belonged to Lévis' army, had been upset with others in a boat, and had succeeded with infinite difficulty in scrambling on to the ice-floe on which he was found. He then informed his rescuers that Lévis was at that moment coming on with 12,000 men against the city. It was about four o'clock in the morning, but the rescued man was carried without delay in a hammock up the steep streets to Murray's quarters, where he repeated his story. Murray was anticipating an attack, but hardly so soon, and the information so strangely fished up from the flood and darkness, proved of vital import. 


\section{VAUDREUIL'S CONVENTIONS}

It was, moreover, entirely correct. All through that night the brave Lévis, amid storm and darkness, through melting snow wreaths and swollen rivulets, was leading the gathered remnants of the French forces to strike one last blow for the colony. Indeed, had it not been for the lightning, he himself declares, all progress would have been impossible. He had not 12,000 men, but he had nearly 8,000 by his own statement, some 4,000 of whom were regulars of the veteran battalions that had done such yeoman service for Canada during the five years of war. They were smarting from the defeat of September, though not all had been in it, and thirsting for revenge. Vaudreuil, whose imagination was invaluable to his cause, had assured them that the British garrison were destroyed by disease, and that a French fleet would assuredly sail up the St. Lawrence the moment navigation opened. Deliberate fabrication seems to be as valuable to-day with a brave and ignorant army to work upon as it was in the days of Vaudreuil.

As regards the British garrison, he was not so wide of the mark as usual, and on the morning of the 27th, Murray mustered them. There were rather over 3,000 men fit for duty, and Sergeant Johnson, whose account of the siege is a notable if rough-and-ready contribution, describes them as "scorbutic skeletons."

For the last few days Murray had been trying to raise intrenchments on the Plains of Abraham, before the city walls, without much avail. But though a vast quantity of fascines and piquets had been cut and the ubiquitous and invaluable MacKellar was there as chief engineer, the still frozen ground defeated their best efforts. MacKellar, from the early 364 


\section{0] RECONNAISSANCE BY MURRAY}

days of Braddock, seems to have represented in his own person everything that was trustworthy in the scientific branch. Generals came and went, but MacKellar was always there. Whether a fort was to be built, or trenches to be opened, or a scientific opinion wanted, so far as one man could supply the need in so many quarters, it was always MacKellar, and it may be noted as significant that he was still only a major. On the 27 th, Murray marched out half his army to feel the enemy and cover the retreat of his outposts. He proceeded to St. Foy, where the plateau, extending westward from the Plains of Abraham, terminates in a slope, and there, from the ridge indicated, where stood the church and several houses, he saw the French clustering thick beyond the marshes and at the edge of the woods. This movement was only intended as a reconnaissance in force, so, having achieved what he wanted, he returned to Quebec, and prepared for more serious action. There has been much discussion as to what Murray should now have done. Theoretically, 3,000 men, supported by a number of semi-invalids who could only contribute some assistance behind walls, ought not to leave a fortified town, whose retention was vital, to attack much more than twice their number in the open field.

It has been said that Murray, who was young and ardent, wished to emulate the fame of Wolfe, and to gratify at the same time the perhaps overweening confidence of his troops, who had come to think themselves irresistible. On the other hand, the defences of the town were bad on that side, and external intrenchments were impossible. He thought that this fact, coupled with the temper of his troops, 


\section{MURRAY OFFERS BATTLE $[1760$}

required aggressive rather than defensive tactics. Rightly or wrongly, however, he marched out upon the following day with every available soldier and a hundred eager volunteers from the sutlers and supernumeraries, 3,100 in all, to give battle to Lévis.

No climatic conditions in any country or at any season are more uncomfortable than those attending the break-up of a Canadian winter. The atmosphere is by turns bitterly cold and unpleasantly warm ; and the ground, hard as iron beneath, is covered with standing water and melting snow. The still naked woods drip by day and freeze by night, while the recently exposed pastures brown, parched and hungry, await the genial touch of spring.

Murray's men, however, marched cheerily through it all, and crossing the memorable ground on which in September they had so nobly proved their prowess, approached the French position. Burton, who had been conspicuous through the whole war, commanded the right, consisting of the 15th, 48th, 58th, and second battalion of the 60th. Fraser had the left, with the 28th, 43rd, 47th, and his own regiment, the 78th Highlanders. The reserve, consisting of the $35 \mathrm{th}$ and the third battalion of the $60 \mathrm{th}$, was commanded by Colonel Young, of the Royal Americans, who had been at Fort William Henry. On the right flank were the light infantry; on the left, Rangers and volunteers. Some twenty guns went with them, dragged, for lack of horses, through the mud and slush by some 400 men. The French right touched the blockhouses, which stood near the Anse du Foulon, where Wolfe had landed. The left of their advance line spread across the ridge, and reached the top of the slope beyond, where stood 366 
a farmhouse and a windmill, while in the rear, the main forces of the French were coming rapidly up from Sillery and St. Foy.

The French vanguard had just begun to intrench themselves, and the bulk of their army were hardly in position when Murray thought the hour had come to strike. The guns, which were scattered between the battalions, opened fire with considerable effect, while the light infantry on the right and the Rangers on the left, under Dalling and Hazen respectively, dashed forward on the extremities of the French vanguard, and drove them from their half-finished redoubts, the centre retiring with them on the main column. But the latter was immensely strong, and hurled forward heavy bodies of good troops, who drove the over-confident British light infantry back in much confusion, to the detriment of the ranks who were coming up behind. There was some sharp fighting around the buildings upon the right and left. Most of them were taken and retaken more than once. The British supports were ordered up, and the whole line pressed too far forward between the horns of the outnumbering and outflanking French. 'There was fierce and, for a time, successful fighting on the British side; but their very ardour injured them, as both guns and men found themselves drawn down into low ground, where the snow and slush was knee-deep and the guns could not be moved. On both sides they encountered not only a flanking fire, but one greatly helped by the cover of extending woods. The light infantry were completely put out of action, and every officer killed or wounded. The French now turned all their attention to the British flanks in desperate efforts to get round behind them and cut them 


\section{REPULSE OF THE BRITISH [1750}

off from the city. They had by this time, according to Murray, 10,000 men in the field, and the 3,000 "scorbutic skeletons," now sadly diminished even from that scant total, were at length forced to fall back. The guns were hopelessly mired, and had to be abandoned; but the retreat was conducted in good order, and there was no attempt at pursuit. Some of the troops, on hearing the order to fall back, to which they were so long unaccustomed, shouted out in indignation, " $\mathrm{D}-\mathrm{n}$ it! what is falling back but retreating?" The battle had not lasted two hours, but it had been an unusually bloody one. Murray's loss was over 1,100 men, more than a third of his force; while that of the French was estimated at various figures between 800 and 2,000.

No time was now lost in preparing to defend the city, for the position was critical. Every one who could stir a hand was set to some sort of work, the women to cooking, and the convalescents to filling sand-bags. Embrasures were made and platforms erected on the walls for mounting cannon. Officers and men worked like horses, the former, with their coats off, helping to drag the guns up the steep streets and hoist them into position.

For a moment there had been faint signs of demoralization in the shape of drunkenness; but Murray crushed the tendency with vigour and by exemplary punishment, and, on his own part, showed unbounded energy in this hour of trial. The odds would seem great, but there was no failing of either courage or cheerfulness on the part of a garrison now reduced to 2,400 effective men, with nothing but some indifferent defences between them and four times their number of reinvigorated French368 


\section{0] THE FRENCH BEFORE THE CITY}

men. But Murray had at least no lack of guns, and these were being rapidly massed along the western walls. It made Sergeant Johnson's heart ache, and outraged his sense of military propriety to see the exertions of the officers. "None but those who were present," says the worthy serjeant, " can imagine the grief of heart the soldiers felt to see their officers yoked in harness, dragging up cannon from the lower town, and working at the batteries with pick and spade."

The French were busy entrenching themselves scarce a thousand yards from the walls, and De Bourlamaque, though severely wounded, was in charge of the operations. Their seven or eight vessels had, in the meantime, dropped down to the Anse de Foulon. Stores of all kinds were being discharged and carried up the cliffs. The French, fortunately for Murray, were weak in artillery, and their guns were dismounted by the accurate and rapid fire of the British almost as fast as they could be set up. With such a great numerical advantage, an assault was the natural proceeding for Lévis to take, and one was hourly expected. "Let them come," said the men; "they will catch a Tartar."

Even now friendly amenities and banter passed between the opposing generals, Lévis sent Murray a present of spruce-pine tops for making spruce beer, and some partridges; while Murray sent Lévis in return a Cheshire cheese. The French leader offered to back himself to capture the city for $£ 500$. Murray replied that he would not rob de Lévis of his money, as he felt quite convinced that he would have the pleasure of shipping him and his whole army back to Europe in the summer in English bottoms. 
Two days after the battle Murray had sent the Racehorse sloop, the solitary ship before mentioned, off to Halifax, bearing the news of his critical situation to Admiral Colville, who with a strong fleet was cruising in those seas. Should English ships get up to Quebec, it was all over with Lévis, for if he was still outside the city, he would have no recourse but in retreat. If a French squadron, on the other hand, should be first in the river, the work of Wolfe would be undone. The former was, of course, far the most likely, but the French troops and Canadians were buoyed up by statements to the contrary. For nine days the British batteries poured shot and shell upon the French, who, busy with their intrenchments, scarcely replied. The air was thick with rumours that a fleet was ascending the river, and signals upon the mountains to the eastward appeared to the garrison to give good grounds for them; but whose fleet was it! A French sloop had run down past the batteries on the 4th. On the 8th she was forging back again before a fresh south-east wind. "Why don't you stop and pilot up your fleet?" the English shouted at her as she went by. But she took no notice, and made up the river to her consorts by the Anse du Foulon. The next morning, May 9th, the reason of the Frenchman's haste was evident, for a ship of war sailed into the basin. There was a brief moment of doubt and suspense as to the vital question of her nationality. Presently, however, her colours ran up. They were those of Britain, for she was the frigate Lowestoft. "The gladness of the garrison," says honest Knox, " is not to be expressed. Both officers and men mounted the parapets in the face of the enemy, and huzzaed with their hats in 370 


\section{0] ARRIVAL OF BRITISH SHIPS}

the air for fully an hour." Captain Deane, having saluted with twenty-one guns, came ashore in his barge, and dispelled all doubts with the glorious news that a British fleet was ascending the river. Lévis, however, had either not received the information or disbelieved it. For though an immediate assault was his only hope, he went on with his approaches as if the whole summer lay before him, throwing but a feeble fire against the British works. The moment a British squadron, of sufficient strength merely to destroy his handful of small vessels, arrived, his position was untenable, for he would have no means of feeding his already hungry army; and on the night of the 15 th that moment arrived.

It was the battleship Vanguard and the frigate Diana that had sailed in; and on the following morning the latter, together with the Lowestoft, favoured by a fresh breeze from the east, sailed past the town and fell upon Lévis' ships. These were two frigates and four smaller vessels, commanded by Vauquelin, the brave officer who had fought his ship so well at the siege of Louisbourg, then plugged her up and sailed through the British fleet for France. Here, too, he fought his small ships most bravely, but one by one they were destroyed, and he himself was ultimately taken prisoner.

The French had nothing for it now but to retreat, and Lévis lost no time. The Vanguard swung out in the river off Sillery, laid her broadside to the French trenches, and enfiladed them from the south. The enthusiastic garrison, who, by working day and night, had got 140 guns into position, opened the most tremendous cannonade, say their officers, that 


\section{THE SIEGE RAISED}

they had ever heard. But the retreat had already begun; and the gunners, elevating their pieces, sent a storm of balls ricochetting and bounding along the Plains of Abraham upon the heels of the fast-vanishing French, who left behind them a long tail of dead and wounded as a result of the fortnight's siege, besides all their guns and stores. The Canadian irregulars, of course, deserted the retreating army, which reached Montreal at the end of May in a sad state of depression. There Vaudreuil and Lévis had to concoct such plans as they were able to meet the overwhelming forces that were even then gathering to move against the doomed colony. Trois Rivières (Three Rivers) was the third town in Canada, lying about midway between Quebec and Montreal. The whole country east of that point was now in British hands; the people had sworn allegiance (the priesthood included) to King George, and had returned with relief, if not with actual joy, to their neglected and often wasted homes. From Three Rivers up to Montreal, and from Montreal on to the rapids, beyond which the English dominated Lake Ontario, was practically all that was left of Canada to the French king. The capture of Montreal would complete the business, and to this end Amherst, by Pitt's instructions, and in full accordance with his own ardour, bent all his energies. Once more, and for the last time, three movements were planned on Canada, and it was hardly possible that what was left her could escape being crushed between them as in a vice. Murray, his small veteran army increasing daily in strength from returning health, carried and supported along an open waterway by an excellent fleet, had the easiest task of all. Am- 


\section{0] THE BEGINNING OF THE END}

herst himself, with nearly 11,000 men, was mustering at Oswego and he was to descend the St. Lawrence to Montreal, the general rendezvous, where the heart of Canada still beat defiantly, if with waning vigour. The physical difficulties here were more formidable than any which Lévis was likely to contrive. Amherst had no full knowledge of the rapids of the St. Lawrence. He counted them as an obstacle, but he hardly realized their fury. As for the third attack, it is needless to say it was from Lake Champlain, whose forts at Crown Point and Ticonderoga now made an admirable base for the forcing of the passage of the Richelieu at Ile aux Noix. Colonel and Brigadier Haviland was given the command of this enterprise, and a force of only 3,500 men, so greatly had the events of the last year altered the scheme of Canadian defence and reduced the strength of its resistance. Lévis had now about 8,000 troops of various sorts at his disposal, besides Indians, with a base at Montreal. Roughly speaking, this city represented the point where the two lines meet which form the letter $T$, the three arms spreading from it being the approaching routes of the three English armies, mustering between them not far off 20,000 men. I do not propose to deal at any length with the details of these three advances, not because there was no fighting, as Amherst and Haviland were both opposed, so far as Lévis' scattered forces could oppose them. But the resistance was necessarily feeble; and it was a question of good organization and energy, rather than military force, which brought to a happy termination a summer's campaigning which, on paper at any rate, looked a foregone conclusion. 


\section{MURRAY SAILS FOR MONTREAL [1760}

To the lover of olden times and quaint description it is pleasant to follow our discursive friend Knox up the St. Lawrence, with Murray's fleet. It was through bright summer days and with thirty-two ships and nine floating batteries they pursued that delightful river journey from Quebec to Montreal, which every passenger by a Canadian liner has nowadays the option of enjoying, and, if wise, does not neglect the opportunity.

Leaving 2,500 invalids and wounded in Quebec to revive with the summer warmth and the abundance of food which incoming ships and the pacification of the country brought to their market, Murray left there with about as many combatants on July the 14th. Lord Rollo, with two regiments from Louisbourg, followed close behind. The whole country in their rear had now sworn allegiance, but Vaudreuil, by sowing false news and proclamations broadcast, was making desperate efforts to shake them. These proclamations are a real curiosity in the art of deception. The credulity and ignorance of the Canadians, great as it was, could hardly have swallowed the announcement that Great Britain was on the point of being compelled to sue for peace, and that the Canadian peasants, in a few weeks, would return once more from British tyranny to that benign Government of absolutism, plunder, and intolerance, which had, in fact, been the cause of all their sufferings. As I have indicated, the adventures of the fleet ascending the river were inconsiderable. It was much the largest ever seen in the higher reaches, and the country people, whose farms and villages lined both banks, regarded it with proper awe, and swore 


\section{0] ASCENT OF THE ST. LAWRENCE}

themselves in as good subjects of King George as readily as they brought on board such provisions as they had to sell. Small military posts, however, remained occupied here and there by the French, who fired at the ships in desultory fashion as they passed, and received their fire in turn. They were not, however, worth wasting time over, for, Montreal captured and Lévis beaten, they would of necessity collapse at once with the rest of the colony. At Trois Rivières there seemed to those on board to be at least 2,000 troops marching along the shore and watching their motions, including the sole body of regular cavalry in North America, well accoutred in blue and red uniforms. They made quite a brave show, says Knox, amid the delightful prospect around-the fine convents and churches, the neat farms and well-cultivated fields. The navigation of the shallow lake of St. Peter gave considerable trouble; but in the deeper and narrower channels amid the islands beyond the scene was quite enchanting. In the chronicler's quaint words, "Nothing could equal the beauties of our navigation, with which I was exceedingly charmed: the meandering course of the channel, so narrow that an active person might have stepped ashore from our transports either to the right or left; the awfulness and solemnity of the dark forests with which these islands are covered, together with the fragrancy of the spontaneous fruits, flowers, and shrubs; the verdure of the water by the reflection of neighbouring woods, the wild chirping notes of the feathered inhabitants, the masts and sails of ships appearing as if among the trees, both ahead and astern, heightened by the promiscuous noise 


\section{ARRIVAL AT MONTREAL}

of the seamen and the confused chatter of the rapturous troops on their decks, formed all together such an enchanting diversity as would be far superior to the highest and most laboured description."

Many of the English captives of Fort William Henry escaped from their masters at the sight of the English fleet, and came timorously on board. When questioned as to their hesitation, they replied that the French priests, to whom fiction seems to have been a positive pleasure, had assured them they would be hanged to a certainty.

But this triumphal and picturesque progress of the British into their new dominion must be cut short, as our space runs out, and events of more immediate moment have to be chronicled. It will be enough to say that Murray crept steadily on, giving those districts which submitted every testimony of present and future clemency, and making a stern example, though with a sore heart, of the few who did not. At the mouth of the Richelieu, where Haviland was expected by the Champlain route, they found large bodies of the main French army, under Bourlamaque and Dumas, waiting for both English attacks, who followed them upon either shore as they forged along the winding river, even then lined with farms and villages, towards the island of Montreal. At the island of St. Thérèse, a few miles below the city, Murray halted, and awaited the arrival of Haviland and Amherst. The former, in the meanwhile, had been pushing the French steadily before him, and arrived below Montreal soon after Murray, where both waited at their leisure for Amherst, who was descending the St. Lawrence 376 
upon the other side of the city, and was even now close at hand. On the 6th of September Amherst arrived, and the triple movement was completed with an accuracy that did credit to all concerned.

Amherst, with 10,000 men, besides Johnson and his 700 Indians, had left Oswego just a month before. With a vast fleet of bateaux and whaleboats, and a few armed craft, he had passed out of Lake Ontario, and down through the thousand islands. Our old friend Pouchot, of Niagara memory, lately exchanged, alone stood in his path, at Fort Lévis, above the head of the first rapids. The British officers, who knew him personally, interchanged friendly banter as the ships came within hailing distance of their late prisoner. After a stout resistance, however, he and his garrison were captured, and Amherst moved on to what was really the more serious matter of the descent of the rapids. Johnson's Indians were with great difficulty kept off the captured garrison. Canadian precedents and the unblushing bloodthirstiness of so many of the priests was a trial even to British humanity. It was almost more than the ethics of the Iroquois could be expected to stand, and two-thirds of them went home in disgust; but happily they were no longer required, and might well have proved troublesome.

The rapids were a much greater cause of anxiety to Amherst than were the French, as any one who knows the St. Lawrence can well understand. He had to navigate over 800 bateaux and whaleboats, with their freights of stores and men, down the seven or eight dangerous places that lay between him and Montreal, and such work is a science to itself. He had 
plenty of men who were masters of it, but the rapids of the St. Lawrence were on a great and formidable scale, beyond average experience. Some local knowledge was necessary, and Amherst had difficulty in securing, through Indians or coerced Canadians, the required experience. He did the best he could, however, and ran the Galops, Point Iroquois, Point Cardinal, and Rapid Plat without disaster, to his own surprise and somewhat premature jubilation. On September the 1st his great fleet of boats went down the Long Sault with not quite such immunity, several soldiers being drowned. The next day they floated over the Lake St. Francis. On the 3rd they went over the Conteau rapids safely. On the 4th the Cedars and Cascades were adventured with a very different result. Sixty-six boats in all came to grief, many of them with their stores being hopelessly lost, and eighty-four men drowned. Still, this did not affect the fate of Canada. On the 6th the British had landed at Lachine, and by evening were encamped within sight of the city, Murray and Haviland being in touch with each other upon its further or eastern side.

The situation of the French, in this their last stronghold, was quite hopeless. Montreal was not a natural fortress like Quebec, and, even if it had been, the inevitable could not have been materially deferred. The Swedish professor, whose memories of Lake Champlain have been quoted in a former chapter, came on to Montreal, and gives us a vivid picture of what it looked like ten years or so before this, the year of its surrender. It had, of course, the St. Lawrence on one side of it, and on the three others a deep ditch full of water. It was surrounded by a high 378 
and thick wall, but covered too much ground, from the scattered nature of the houses, to be defended by a small force. Unlike Quebec, too, most of the private houses were of wood, though admirably built. There were several churches and convents and seminaries, - fine buildings of stone, mostly surrounded by spacious gardens,- -while the streets were broad and straight, and some of them paved. In the background rose "the Mountain," then clad in virgin forests, which, upon this fateful 7 th of September, had not as yet been touched by autumn's fiery hand. Before the city flowed the noble river, not long calmed down from the fury of the La Chine rapids, and at this point little less than two miles broad. Knox more than endorses Kalm's eulogies, and thinks Montreal the most delightful place he has seen. The fortifications were contemptible, but "the excellence of the private houses, the magnificence of the public buildings, the pleasant country seats and villas scattered about amid gardens and plantations outside the walls, and, above all, the charm of the situation," enchants the gallant captain, ${ }^{1}$ in a mood, no doubt just then, to be easily pleased. To see the gay crowd in the streets, too, the silk cloaks and laced coats and powdered heads, one would have supposed, he says, that these people, instead of being the victims of a long and disastrous war, were all in the enjoyment of ample and unimpaired fortunes. But this is anticipating a little, for Knox and his friends were not yet actually inside.

Here, within or around the city, if importance in lieu of population can justify the term, were gathered all the civil and military chiefs of Canada, for once,

1 Knox would seem to have got his majority about this time. 


\section{THE FRENCH SURROUNDED}

at least, united in the conviction that all hope had fled. The thoughts of the civilians had by far the most cause to be gloomy. The Intendant Bigot, Cadet and their band of parasites saw with despair the bone they had so long picked, passing from their grasp-the goose that for them alone had lain so many golden eggs at length on the point of extinction, a fate in part due to their former imprudences. But worse than all they saw an outraged king and government beyond the ocean, who, maddened with their loss, would welcome with joy the poor consolation of demanding an account of a stewardship so infamously outraged. As for the military leaders, however bitter their feelings, they were those of brave and honourable men, suffering the chagrin of defeat which they had for some time become accustomed to regard as inevitable. Lévis, Bourlamaque and Bougainville had little cause for self-reproach, for they had done all that men could do. Since the near approach of the British a rapid dissolution of the French army had set in. The Indians had entirely repudiated their ancient allies and patrons, while the militia had gone home to a man. The married soldiers of the colony regulars had in great part deserted, while many of the French linesmen who had married in the country had done the same. Only 2,500 troops, mostly French regulars, now remained with Lévis and his officers. They had provisions for a fortnight, and represented the entire resisting force of the colony. Amherst, Murray and Haviland lay outside the town with seventeen or eighteen thousand men, mostly veterans. It was, indeed, the end of all things. Vaudreuil held a council of war on the 6th, which was naturally unanimous, on the necessity of an immediate capitu- 
lation. Bougainville, however, was sent early on the following day to Amherst with a proposal to suspend hostilities for a month-which reads like a very poor joke. Vaudreuil perhaps felt ashamed of it as he quickly followed with an offer of capitulation, specifying terms which had been approved by his council. There were forty-five clauses, most of which Amherst agreed to, though a few were summarily rejected. Lévis and his officers had fully counted on being allowed to march out with their arms and the honours of war. Amherst bluntly insisted that the troops should lay down their arms unconditionally as prisoners, and undertake not to serve in Europe during the present war. Lévis bitterly resented this, and himself sent de la Pause, his quartermaster-general, to plead with the English general against this rigorous condition. Amherst, however, not only refused, but, according to Knox, who was on the ground, sternly silenced Lévis' envoy, and told him that he was "fully resolved, for the infamous part the troops of France had acted in exciting the savages to perpetrate the most horrid and unheard-of barbarities in the whole progress of the war, and for other open treacheries, as well as flagrant breaches of faith, to manifest to all the world by this capitulation his detestation of such ungenerous practices and disapprobation of their conduct, therefore insisted he must decline any remonstrance on the subject."

Upon this Lévis demanded of Vaudreuil that the negotiations should be broken off, or if not, that the troops should retire to St. Helens island upon their own responsibility, and resist to the utmost rather than accept such terms. One does not, of course, feel 381 


\section{SURRENDER OF CANADA}

quite convinced of the sincerity of a suggestion that was so superfluous, and not perhaps palatable, and certainly unfair, to the rank and file. But in any case Vaudreuil remained firm, and on the 8th of September the capitulation as amended by Amherst was formally signed. Thus, by a stroke of the pen, Canada was transferred to the British crown, and, save for the small settlement of New Orleans, far away in the remote South on the Gulf of Mexico, the French power, recently so potent and so threatening, disappeared for ever from North America. Among some of de Vaudreuil's stipulations was one that the British Indians should be sent away. Amherst refused it, proudly replying that no Frenchmen surrendering under treaty had yet ever suffered from outrage by Indians co-operating with a British army. The gist of the articles of capitulation may be briefly summed up. All the regular troops in Canada, not only at Montreal, but the small isolated garrisons, together with the officials, civil and military, were to be conveyed to France in British ships. Whoever wished to leave the country was permitted to do so, a period of grace being given for the winding up of necessary business matters, such as the collection of debts or sale of property. Entire religious freedom was wisely granted, though a clause reserving a power of clerical appointments to the French throne was as wisely rejected, while some minor clauses, though not rejected, were reserved for the King of England's pleasure.

Amherst sent in the able Swiss officer, Haldimand, to take possession of the conquered city, as being, perhaps, especially acceptable to the French at this bitter moment. A regrettable incident marred this 


\section{0] A REGRETTABLE INCIDENT}

final scene, unworthy both of the men and the occasion. When Lévis delivered up the paraphernalia of his army no French flags were forthcoming, and to the remonstrances of Amherst and Haldimand, he affirmed that they had been accidentally destroyed. Nobody wished to believe a brave antagonist guilty of so petty an outrage against all the laws of war and honour. But it was known in the British army that the French flags had been used by their owners since any serious engagement had been fought, and it is quite certain that neither Amherst nor his brigadiers believed Lévis' statement.

It is a pity that such an incident should stain de Lévis' Canadian record, and that a brave soldier, whose very surrender, like Lees at Appomatox a century later, presented a nobler spectacle than many victories. It was of a truth not the fault of those who had fought for Canada that she had fallen. De Lévis, de Bourlamaque, de Bougainville, Dumas, Pouchot and de la Corne, and their brothers in arms who stood as prisoners of war on the island of Montreal, had no lack of faith or vigour or valour to reproach themselves with. It would have been well for France had she possessed their equivalents at that time in Europe - officers as faithful under discouragement and neglect, as hardy and tireless in the field. Nor is it at all likely that she had at that moment any troops of quite such a quality as those seasoned veterans of the seven famous regiments, who gave up their arms to Amherst's overwhelming force, but had found their match upon the Plains of Abraham. It was little thanks, however, these brave men ever got from the country, who, to its own dire misfortune, had left them in the lurch. 


\section{A NOTABLE GROUP}

Montcalm, the first of them all, got little indeed but calumny. It has been left for Englishmen and Canadians to keep green the memory of an able and merciful soldier and a worthy gentleman. No monument in the world is more suggestive than that simple shaft upon the Heights of Abraham, erected by the two races whose ancestors fought there, to the joint memory of Wolfe and Montcalm.

It was a well-seasoned and a war-worn group, too, that gathered round the victorious Amherst in the Place d'Armes at Montreal, when he paraded his troops for the formal submission of the Marquis de Vaudreuil. Some of the chief actors in the past seven years of war, Monckton, Bouquet and Washington, were absent with good cause. Wolfe and Prideaux, the elder Howe and Braddock, Forbes and many others, were in the grave. Two or three had laid their reputations there, but were themselves still among the living, though beyond the sea.

But at that ceremony, whose infinite significance is more apparent to our eyes now than to those of the purblind and preoccupied Europe of that day, there was a goodly throng of warriors who had well earned the exultation that was theirs. Some of them lived to win far greater fame, others to bury such as they had won in a still distant struggle upon the same familiar scenes.

Murray and Haviland led their brigades. Burton and Gage, who had seen the whole war through from the commencement, and Fraser, the gallant Highlander, headed their respective regiments. Carleton, who was to become a famous Viceroy of Canada and to die Lord Dorchester, was here; and Howe, too, whose leadership up the cliffs at the Anse 


\section{A WAR-WORN GROUP}

du Foulon was to be unhappily forgotten in his failure against the Americans in after days. The Swiss soldier and scholar Haldimand, who was also to govern Canada wisely and well, was in the group. Sir William Johnson, the baronet of the Mohawk valley, the master spirit of the Six Nations, the only white man on the continent the Indians really bowed to, was here, tall and muscular, cheery and unceremonious. No such picture would be complete without Rogers. No man had faced death so often-Rogers with a hundred lives, that prince of backwoods fighters, and his two brothers, each commanders of companies, and only inferior to himself. Dalling and Hazen, too, though but captains, as leaders of light infantry it would be ill forgetting. Schuyler and Lyman, the New York and Massachusetts colonels, in blue uniforms and three-cornered hats, were conspicuous among their fellows, and were to be heard of again in still more conspicuous fashion. Nor should we forget in what is after all but a partial, and, perhaps, even invidious retrospect, the gallant naval captain, Loring, who handled Amherst's improvised fleets on Lake Champlain and the St. Lawrence with unwearied energy; nor yet Patrick Mackellar, whose forts and ramparts and redoubts were strewn over the whole range of conflict, and may yet be traced by the curious under forest leaves, or amid bustling towns, or in track of the farmer's plough. Jealousies between redcoats and bluecoats and men in hunting shirts, we may well believe, were now, at any rate for the moment, laid to rest. Within a few days ship after ship bearing the remnants of the French army had dropped down the river. All that remained was to carry Vau385

C C 


\section{THE FINAL CEREMONY}

dreuil's orders of submission to the small French posts upon the St. Lawrence and in the West, and to hoist the British flag in a score of lonely spots where the lilies of France had floated since the first white men broke upon their solitude. 


\section{CONCLUSION}

SINCE brevity is the plea upon which this nar$S$ rative chiefly relies for its justification, I shall make no apology for having kept almost wholly aloof from the contemporary events in Europe during the Seven Years' War. For the same reason, I had fully intended to let the surrender of Vaudreuil and Lévis at Montreal be the final word of this volume, and to resist all temptation to touch upon the great questions that the war gave rise to.

Now, however, that I have come to the end of my allotted tether, I feel that the word finis, written where I had intended to write it, would lay me open to a charge of somewhat inartistic abruptness, both in a literary and historical sense, and that a story so suddenly closed would exhibit a lack of finish and completeness that three or four pages more would go far, I trust, to rectify.

Now Vaudreuil signed those ever memorable articles of capitulation on September the 9th, 1760, within a few days of the first anniversary of Wolfe's death, and in due course, in accordance with the terms of the document, the remains of the French army, the entire body of officials, and a certain number of the leading gentry, by their own wish, were carried to France in British ships. 


\section{CONCLUSION}

Pending the peace a military government was set up in the Colony, which was divided for this purpose into three districts-Quebec, Three Rivers, and Montreal-respectively assigned to Murray, Burton and Gage. The precise forms of this government do not concern us. It will be enough to say that it was conducted with the utmost possible consideration for the people, for their religion, their language, and their laws. One must not undervalue the strength of racial sentiment, but, with that exception, the people found themselves in every respect better off than they had ever before been, and did not hesitate to proclaim the fact in loud and grateful tones. If the ignorant mobs who, in various parts of Europe and America, screech their pitiable stuff about British tyranny and the more enlightened few, who, for motives base and of deliberation, thus bear false witness against their neighbour, desired light or truth, which is not in the least likely, the epoch in question would be an admirable point for them to commence their investigations.

It has been well said by historians, neither English nor French, that, throughout the whole hundred and fifty years of French rule in Canada, there is no evidence that the well-being, the happiness or the comfort of the people was ever for a single moment taken into consideration. They had been, in fact, slaves-slaves to the corvées and unpaid military service-debarred from education and crammed with gross fictions and superstitions as an aid to their docility and their value as food for powder. It is no wonder that they were as gratified as they were astonished when they found the Englishmen of reality bore no resemblance whatever to the Eng- 


\section{CONCLUSION}

lishman of priestly fiction. The common people were to their surprise officially informed of all public events, and the gentry class, who had hitherto had no share whatever in the government, were enrolled in various capacities as the custodians of law and order. When King George died, a few weeks only after the surrender of the Colony, the people of Montreal went of their own accord into mourning and presented an address, declaring he had treated them as a father would treat his own children rather than as a conquered people. And all this was under military government, for two years yet remained before the peace and the Treaty of Paris, which was to formally annex Canada to the British crown: when, as every one knows, the same policy was continued under a civil administration.

For more than twenty years there were practically no English-speaking settlers in Canada, and but a few thousand in Nova Scotia and the adjoining coasts. It was not till the close of the War of Independence, that the stream of American loyalists set in for the maritime provinces and the virgin forests of Ontario and laid the foundations of the dominion of Canada as we now know it.

In the meantime a Nemesis awaited the Canadian civil officials who had so betrayed their trust and their country. The very seas rose up against them as they beat their way homewards through danger, misery and tempest. Upon landing, ten of them, headed by Vaudreuil, Bigot and Cadet, were at once arrested and thrown into the Bastile. Twenty-one in all were put on trial, and so severe were the punishments in the shape of fine and banishment, that most of them only survived as broken and ruined men. 


\section{CONCLUSION}

Though North America had peace, the war dragged on in Europe and elsewhere for over two years. In the month following the surrender of Canada to Amherst, King George, as I have mentioned, died, thus closing a long reign that he had at any rate done nothing to prevent being for the most part a glorious one, while he had proved himself to be at least a brave, an honest, and a constitutional monarch.

The pitiable debut of his youthful grandson at this exalted period is a familiar picture. That he was an ardent Englishman, and meant well, that he was fond of agriculture, and above reproach in morals, may be of abstract interest, but is of slight importance in history when weighed against his pernicious actions, and more particularly when it is remembered that his domestic virtues had small effect on the country, but were rather objects of ridicule. It is the failings of George III. that matter, and constitute him, in the opinion of many, the most mischievous monarch that ever sat upon the throne of England. Personally pure and patriotic, he practised corruption at home and courted disaster abroad with tireless industry in the pursuit of that dream of absolutism which had been so religiously instilled into his obstinate nature by a narrow-minded mother.

He began almost at once to show his hand, and make it evident that the glory of England was quite a secondary matter to the pursuit of his mischievous and narrow ideal. Pitt, with his proud spirit and imperial convictions, was impossible in the atmosphere that soon surrounded the new king, and his very eminence had gained him powerful enemies. Happily his work was done, when, to the discontent 


\section{CONCLUSION}

of the people, who pelted his successor with mud and stones, he was forced to resign the leadership he had used with such unparallelled effect. But the machinery he had set in motion ran on with the impetus he had given it till its work was accomplished and a glorious peace secured.

Never, probably, in our political history, has there been such a drop as that from Pitt to the obscure and incapable coxcomb who almost immediately succeeded him, pitchforked by the young King into the highest office of state. Even Newcastle, who trimmed again to get office, lent moral weight to Bute. But of what object to criticize the ministers of a king whose settled policy it was to retain such men, and through their means to suborn and degrade Parliament!

Frederick of Prussia, who, with Pitt's help and the indomitable courage of himself and his soldiers, was still holding his own against a legion of foes, may well have despaired at the fall of his great ally, and the advent of ministers who had shown him of late but little sympathy. The timely withdrawal of Russia and the increasing difficulties of France, however, enabled him to hold out till the peace, preserve his dominion inviolate, and hand down a priceless legacy of glory to the great empire, whose foundations he had laid.

The spirit of Pitt lived on in his soldiers and sailors, and the French were beaten at every point and in every hemisphere, by land and sea. Spain was induced to range herself with England's enemies, and paid for it by the speedy loss of Manilla, the Philippines, and Havannah, the latter stormed in the teeth of infinite difficulties and with great loss of life. All nations, except perhaps the English, were anxious 


\section{CONCLUSION}

for peace, and the King of England, for reasons of his own, was of the same mind. So the Seven Years' War was brought to an end in the autumn of 1762 , and the Treaty of Paris was signed early in the following year. ${ }^{1}$ Never before or since has the glory of England been written so large upon any document of the kind. Pitt and a majority of the nation, however, thought it was not glorious enough, and with some reason from the standpoint of their day. It was France who had thrown herself across the path of British colonial expansion, had provoked the struggle and incited her Indian allies to the commission of continuous and fiendish barbarities on the English settlements. This rankled deeply in men's minds, and the more so as England was in a position to dictate terms and still full of fight, while France, crippled, demoralized, and financially ruined, was practically powerless outside her own borders. It was the French, too, who had essayed to drive the British out of India, with what result needs no telling. The sentiment embodied in the brief phrase, never again, current at this moment in another hemisphere, was the watchword of a majority who had already been tricked by the young King out of their power, and Pitt was of course their spokesman.

Great as were the concessions to Britain in Asia and America, they did not seem to Pitt the full measure of her supreme position and of the blood and treasure she had lavished to attain it. Above all the gift of those two rocky islands off Newfound-

1 Havannah was exchanged with Spain for Florida, New Orleans alone was left to France on the North American mainland, and as Louisiana was afterwards made over to the United States, the dismantling of the fortifications of Dunkirk under English engineers is of all the clauses of this treaty, perhaps, the most significant of the position of England at the moment. 


\section{CONCLUSION}

land to France, which have been ever since such a fruitful cause of friction and danger, stirred Pitt's prophetic mind to wrath. Swathed in flannels he was carried into the House, and there in eloquent and impassioned tones, while denouncing the treaty, predicted to an unbelieving and largely bribed audience those future troubles with which we are only too familiar. But he spoke to deaf ears; the terms of the treaty were approved, and if the King bribed the House of Commons, it is almost equally certain that France bribed Bute with a most princely fee for his services on her behalf.

The question of Canada stood on a different basis. Many were against retaining it upon grounds purely patriotic, and they will be obvious at once. The exaltation of the hour, and a very natural ignorance of colonial feeling, alone prevented those who opposed retention from being more numerous. Many of England's enemies chuckled and have left written testimonies to their foresight. Many of England's friends, and some of her own people, shook their heads. There was no mawkish sentiment about this: it was a purely practical question. There are no doubt, even yet, numbers of people in England who, so far as they think about the subject at all, believe that the infatuation of George III. alone drove into rebellion a people hitherto wholly contented with their lot and pathetically devoted to the Crown and the British connection. Among those who knew the American Colonies at that time there was much difference of opinion as to their drift in certain eventualities, which is in itself significant enough. While the French were in Canada such speculations had no practical interest, for it must be remembered that the ex- 


\section{CONCLUSION}

pulsion of the French was an eventuality not taken into consideration till Pitt's time. It was impossible that there should not have been discontent at the trade restrictions under which the colonists lay. Such discontent may have been illogical, and even ungrateful, as this was the price paid for the protection of England against dangers which were then very real, but that it existed is beyond dispute, though little enough of it, doubtless, was heard amid the triumphs of this particular moment. It had been said by a great many people hitherto that nothing but fear of the French kept the Colonies so docile. The notion that they would seek independence was scouted, it is true, by some of their own foremost men, Franklin among them. But then it is significant that the reason usually assigned for this is their incapacity for combination, not their unconquerable affection for the mother country. Yet, the greatest pessimist of that day would hardly have hazarded the opinion that this vital question would be put to the) test, in less than two decades, and upon provocation) that to many of their generation would have seemed) mild indeed. As a great English historian has trulyl said, and a scarcely less distinguished American has) truly echoed, "the death of Wolfe upon the plains of Abraham meant not only the conquest of Canadal but the birth of the United States," and nothing, most) assuredly not the ignorant howlings of a hetero-t geneous mob, so-called Americans of to-day or yesterday, men who have no part or lot in the great days of old, and often not so much as even kinship with) either branch of the conquering race, can rob England/ of her glorious motherhood. It is quite certain that, no genuine American would ever wish to. 


\section{INDEX}

\section{A}

Abercromby, General, 147, 232, 233, 239, 261, 263.

A bernakis Indians, 342. Abraham, Plains of (see Quebec). Acadia, Condition of, 47-55.

Acadians, Deportation of, 121133.

Adirondacks, The, 114.

Aix-la-Chapelle, Treaty of, 1, 3, $40,42$.

Albany, 76, 109, 114, 147, 149, $198,233,234$.

Albany traders, 112.

Albemarle, Lord, 80.

Alexandria, 82, 86.

Alleghanies, The, 3 .

Alleghany River, 276.

Amherst, General, 211, 219, 222, $223,225,227,228,229,232,261$, 269, 290, 335-341, 346, 353, 373, 377, 378, 380, 381, 382, 384 .

Amherst, Captain, 231.

Aréthuse frigate, 225.

Aubry, 357.

\section{B}

Barrington, 337, 356.

Béarn, Regiment of, 155, 189.

Bellaitre, 201.

Beaumont, 303.

Beaujeu de, 97.

Beauport Lines, 297, 299, 303, $304,308,321,329$.
Beausejour, Fort of, 54, 121, 122, 123.

Bigot, 60, 125, 137, 206, 380.

Black Watch, 253.

Blakeney, 143.

Blue Ridge, 89.

Boscawen, Admiral, 81, 215, 219, 220, 232.

Boston, 15 .

Bourlamaque, de, 144, 193, 196, $239,253,316,339,342,376$, 380, 383.

Bougainville, de, 144, 190, 192, $194,202,253,313,315,320,321$, $322,331,380,381,383$.

Boisherbert, 226.

Bouquet, Colonel, 219!270, 272, 273, 274, 275, 278, 279, 280, 284.

Bradstreet, 155, 242, 263, 265, 266, 267.

Brown, Lieutenant, 221.

Braddock, 81-99.

Braddock's road, 272.

Breton, Cape, 46, 47.

Bullitt, Captain, 276, 277.

Burton, Colonel, 232, 315, 326, 384.

Byrd, 271.

Cadet, 380.

Campbell of Inverawe, 254.

Canada in 1750, 29-39; Government of, 35; Militia, 38.

Cap Rouge, 313, 317, 331. 


\section{INDEX}

Carter, Landon, 106.

Carleton, 291, 384.

Catherine of Russia, 140.

Céleron, de, 43.

Centurion, H.M.S., 308.

Champlain, Lake, 106, 112, 343.

Charles River, St., 297, 320, 332.

Charleston, 22.

Chatauqua lake, 43.

Chebucto bay, 216.

Clerk, Engineer, 247.

Colonies, British, in 1750, 8-28.

Colville, 370.

Connecticut, 10, 12.

Colonial Government, 27, 28.

Contrecœur, Le, 66.

Cork, 170.

Corne, de la, 348, 349, 383.

Cornwallis, 51.

Coromandiere, Le, 220.

Coudres, île aux, 295.

Crown Point, 106, 112, 114, 116, 147, 340, 342, 346, 373.

Cumberland, Duke of, 163.

Cumberland, Fort, 90, 91, 102.

Dalling, Major, 367, 385.

Deane, Captain, 371.

Defiance, Mount, 247, 248.

Delaware Indians, 153.

Desgouttes, Admiral, 224.

Deschambalt, 313.

Detroit, 37, 147, 351.

Devonshire, Duke of, 162.

Diana, H.M.S., 371.

Diamond, Cape, 298.

Dinwiddie, Governor, 57, 61, 65, 66,75 .

Dieskau, Baron, 108, 114, 119.

Drucour, Governor, 224, 227.

Dumas, 97, 99, 168, 376.

Dunbar, Colonel, 85, 92, 94, 104.

Duquesne, Governor, 56.

Duquesne, Fort, 67, 86, 89, 92, 114, 268; Fall of, 285.

Durell, Admiral, 294, 295.

Dutch traders, 77.

\section{E}

Edward, Fort, 115, 190, 196, 197, 200, 237, 261.

Edward Island, Prince, 229.

Erie, Lake, 30, 187, 349, 351.

Etchemain, River, 315.

Evangeline, 53.

Eyre, Captain, 118, 167.

\section{$\mathbf{F}$}

Fairfax, Lord, 89.

Fairfax family, 61 .

Farquhar, Colonel, 352.

Ferguson, 220.

Florida, 8.

Forbes, Brigadier, 268-285.

Fox, 164.

Francis, St., 342, 344.

Franklin, Benjamin, 76, 88, 89.

Franquet, 217, 229.

Fraser, Colonel, 384.

Frederick King of Prussia, 139, 288.

Frontenac, Fort, 37, 110, 155;

Capture of, 263-266.

Fry, Colonel, 66.

\section{G}

Gage, Colonel, 95, 96, 97, 242, $339,353,384$.

Galissonière, de la, 40.

George II., King, 2, 267.

George, Lake, 114, 152, 233, 237.

Georgia, 22.

Germans of Pennsylvania, 78, 201.

Gist, Christopher, 62, 64, 93.

Grant, Mrs., of Laggan, 111, 234.

Grant, Major, 274, 278.

Grant, Ensign, 221.

Great Meadows, The, 67, 69, 103.

Greenaway Court, 62.

Gordon, Engineer, 96.

Goat Island, 218, 224.

Guienne, Regiment of, 155, 189 . 


\section{INDEX}

\section{$\mathrm{H}$}

Halifax, 48, 122, 169, 172, 177, 180, 181, 216, 229, 292.

Half King, The, 67.

Halketts, The, 85, 100, 286.

Haldimand, Colonel, 347, 348, 349, 352, 382, 385.

Hamilton, Governor, 176.

Hanoverian troops, 162.

Hardy, Sir Charles, 174, 180.

Haviland, Brigadier, 373, 378, 384.

Hawke, Admiral, 214, 215.

Hay, Sir Charles, 183.

Hazen, Captain, 359, 367, 385.

Henderson, 326.

Hendricks, 116, 118.

Herkimer, Fort, 202.

Hervey, Captain, 352.

Hocquart, Admiral, 81.

Hochkirchen, Battle of, 288.

Holmes, Admiral, 313.

Holborne, Admiral, 81, 171, 180, 183.

Hopkins, Lieutenant, 222.

Hopson, Governor, 54.

Houlière, de la, 229.

Howe, Lord, 182, 202, 211, 237, $244,245$.

Howe, Captain, 318, 319, 324, 384.

Hudson River, 13, 115, 116.

Hudson Forts, 198.

Hudson Bay Company, 38.

Huguenots, 14, 22.

Illinois, $185,351$.

île-aux-Noix, 340.

Irish Catholics, 24.

\section{$J$}

Jacques Cartier, 330, 331.

Jerseys, The, 338.

Jervis, Lord, 316.
Johnson, Sir W., 76, 86, 107, 112, $115,116,117,119,149,152,153$, $200,248,282,349,350,352,385$.

Johnson, Sergeant, 364, 367, 377.

Johnstone, The Chevalier, 321, 330.

Jonquière, Governor, 46, 56 .

Jumonville, 68, 69, 72.

\section{K}

Kalm, Dr., 234.

Knox, Major, 167, 174, 232, 300, $312,325,328,334,370,374$.

$L$

La Corne, 190.

La Motte, Admiral, 184.

La Sarre, The Regiment of, 189.

La Salle, 42.

Languedoc, The Regiment of, 189.

La Reine, The Regiment of, 189.

Langy, de, 243.

Lawrence, Governor, 122, 126, 127, 128, 211, 219, 220, 222.

Lawson, Sir Wilfrid, 214.

Le Bœuf, Fort, 57, 63.

Lévis, de, 144, 155, 196, 206, 241 , $301,303,305,308,314,315,330$, 331, 335, 346, 356, 357, 362, 363, 364, 366, 369, 371, 372, 373, 380, 381, 383.

Lévis, Point, 360.

Lewis, Major, 271, 274, 275, 276, $277,278,361$.

Lee, Captain, 243.

Ligneris, de, 275, 278, 282, 350, 351.

Lorette, 358, 362.

Loring, Captain, 385.

Loudon, Lord, 147, 149, 150, 151, $165,174,175,180,181,182,200$, 210.

Louis XIV., 30.

Louis XV., 43, 288.

Loutre, le, 52, 325. 


\section{INDEX}

Lowther, Miss, 290, 316.

L'Ours, de, 330.

Loyalhannon, 278, 279.

Louisbourg, 13, 50, 86, 122, 181, 260.

Louisbourg, Siege of, 216-230.

Lyman, Colonel, 115, 120, 149, 385.

\section{M}

Macdonald, Captain, 276, 277.

Mackellar, Major, 94, 155, 290, $298,364,365,385$.

Maryland, 21, 65, 204.

Marin, 56, 350, 351.

Maria Theresa, 139.

Massachussets, 10,12, 113, 205, 232.

Memphramagog, Lake, 345.

Mercer, Colonel, 111.

Michillimackinac, 187.

Micmac Indians, 53.

Minorca, 143.

Mission Indians, 185.

Mississquoi, 343.

Mohawk river, 77, 154, 201.

Monckton, Brigadier, 54, 122, $126,291,301,304,307,309$, $327,378,380,384,385$.

Montreal, 37, 43, 154, 157, 177, $197,206,239,241,266,376$, 379; Surrender of, 382.

Montcalm, 144, 154, 157, 197, 239-259, 296-329 ; Death of, 329.

Monongahela river, 94, 274.

Monroe, Colonel, 169, 171, 176, 189, 191, 192, 195.

Mordaunt, Sir John, 214.

Montmorency, Falls of, 297, 299, $304,314,321$.

Montigny, 351.

Mount Vernon, 85.

Murray, Brigadier, 291, 313, 335, 354 , 356, 358, 360, 363, 364, $365,367,370,372,374,376$.
N

Necessity, Fort, 70.

New Hampshire, 10.

New Jersey, 14 ; Militia, 153.

New Orleans, 41.

New York, 13, 108, 200, 210, 231, 338; regiment, 73 .

Newcastle, Duke of, $79,138,163$, $164,208$.

Niagara, 86, 106, 145, 147, 160, 291; Capture of, 347-352.

Noblesse, Canadian, 33, 34.

North Carolina, 73, 203.

Nova Scotia, 125, 200.

Noyan, Payan de, 264, 265.

\section{O}

Ohio, The, 40-46, 276.

Oneida, Lake, 110, 201.

Ontario, Lake, 110, $201,349$.

Orleans, Isle of, $299,307$.

Orme, Captain, 83, 84, 89, 91, 94, 101, 102.

Osborne, Admiral, 214.

Oswego, Fort, 110, 145, 147; Capture of, 153-158, 201, 264, $347,373$.

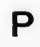

Pause, de la, 381.

Patroon families, 14.

Penn family, 135.

Pennsylvania, 15, 204, 268, 338.

Pepperell, 155.

Peter, Lake St., 375.

Philadelphia, 15, 133, 134, 232, 281.

Picquet, Abbé, 348.

Pitt, 138, 161, 162, 163, 164, 208 260, 288, 291, 393.

Pitt, Fort, 283, 350, 353.

Pointe-aux-Trembles, 362.

Pompadour, Madame.

Post, 281, 282. 


\section{INDEX}

Pouchot, Captain, 349, 352, 377, Shewanoe Indians, 153.

383.

Presqu'ile, 351.

\section{Q}

Quebec, 34, 177, 206.

Quebec, Siege and capture of, 296-333.

Quebec, Murray's garrison in, 354-371.

R

Racehorse, sloop, 374.

Ramezay, Governor of Quebec, 298, 306, 330-3.

Rascal, Fort, 155.

Rattlesnake Mountain, 239.

Reastown, 272.

Répentigny, de, 350-1.

Rhode island, 10.

Richelieu river, 115, 340, 373.

Rigaud, 154, 167, 168.

Robinson, Sir Thomas, 79.

Rochefort, 214.

Rogers, 237, 242, 243, 244, 245, $261,385$.

Rollo, Lord, 374.

Roosevelt, Theodore, 106.

Roussillon, Regiment of, 189.

Ruvigny, de, 327.

\section{S}

Sabbath Day Point, 243.

Saguenay river, 294.

Saint Foy, 357, 358, 362 ; Battle of, 365-7.

Saunders, Admiral, 292, 294, 300, $319,335$.

Schuyler family, 234, 243, 385.

Scott, Colonel, 125.

Scotch-Irish, The, 23-26, 179.

Senerzergue, 330.

Shirley, Governor, 57, 86, 106, $111,122,126,145,146,148$, 154.

Sillery, 367.

Sinclair, Sir John, 95, 271.

Six Nations, 8, 10, 39, 77, 347.

South Carolina, 22.

St. Pierre, Legardeur de, 57, 62.

St. Laurence, Rapids of the, 378.

Stanwix, 353.

Starke, 237, 243, 303.

Stobo, 307.

Stewart, Captain, 101.

Superior, Lake, 37, 185, 187.

Sutherland, H.M.S., 306, 316, 318.

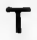

Temple, Lord, 161, 164.

Thousand Islands, The, 201.

Three Rivers, 372, 375.

Ticonderoga, Fort, 121, 147, 152, $167,186,200$; Battle of, 231261; Capture of, 339-41, 346, 373.

Toulon, 214.

Townshend, Brigadier, 291, 307, 308, 327, 328, 331-4, 346, 373.

\section{U}

Ulster immigrants (see ScotchIrish).

Utrecht, Treaty of, 44, 47.

\section{V}

Van Braam, 62, 71.

Vanguard, H.M.S., 371.

Vaudreuil, Marquis de, 80, 106, $144,154,166,167,168,177$, 197, 201, 202, 207, 239, 240, $265,295,329,339,356,357$, $361,372,374,381,384$.

Vauquelin, de, 371.

Venango, Fort, 351.

Vergor, de, 123, 319.

Villiers, de, 7, 154, 352.

Virginia, 16, 19, 261. 


\section{INDEX}

W

Walpole, 334.

Ward, 66.

Washington, George, 61-65, 67, $69,85,92,94,101,102,105$, $132,179,203-6,279,337,384$.

Washington, Laurence, 61.

Webb, Colonel, 147, 176, 189, 201.

Westerham, 212.

Whitmore, Brigadier, 211, 220, 221, 229, 232.

Williams, Colonel, 116, 386.

Williamsburg, 65, 66, 81.
William Henry, Fort, 115, 119, 149, 167, 168, 171, 182; Capture of, and massacre, 186-202, 237.

Wills Creek, 67, 73, 89.

Winslow, Colonel, 122, 124, 126, 128.

Winchester, 89.

Wolfe, General, ; Early life, 211214 ; At Louisbourg, 216-226 ; At Quebec, 289-326.

Wood Creek, 159.

Young, Colonel, 192, 366.
} 



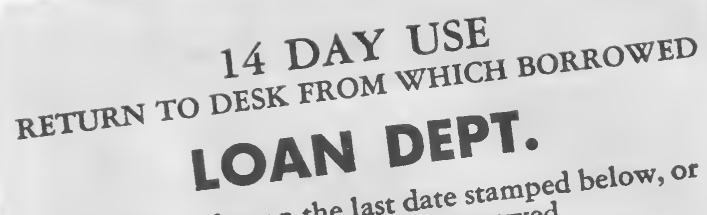
This book is due on the last date stamped.

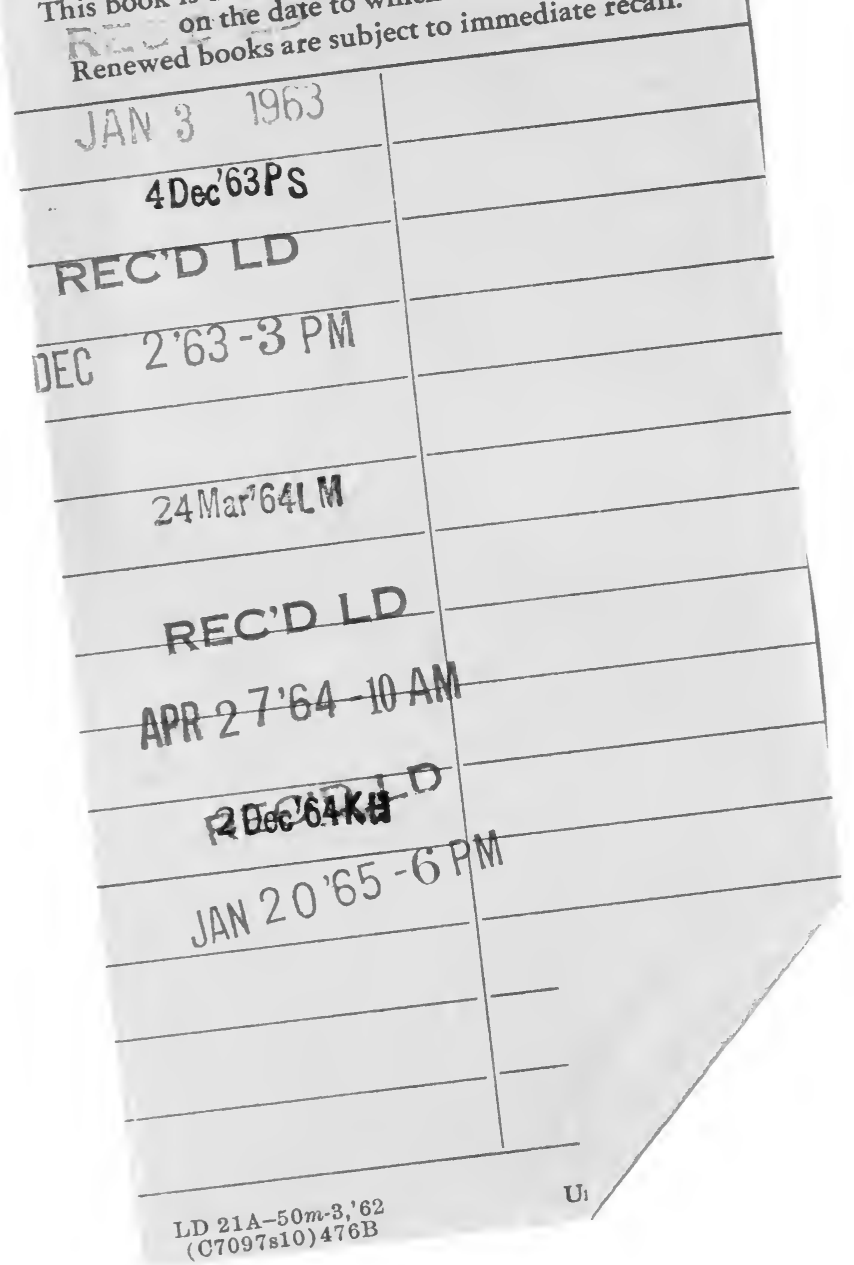




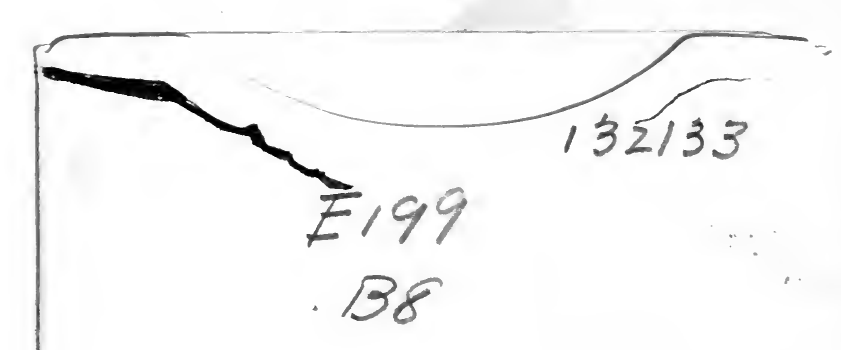

THE UNIVERSITY OF CALIFORNIA LIBRARY 
